\title{
LÉGKÖRKÉMIAI FONTOSSÁGÚ KISEBB GYÖKÖK ÉS MOLEKULÁK AB INITIO TERMOKÉMIÁJA
}

Doktori (Ph.D.) értekezés

NAGY BALÁZS

okleveles vegyész

Témavezetô:

DR. TASI GYULA

egyetemi docens

Kémia Doktori Iskola

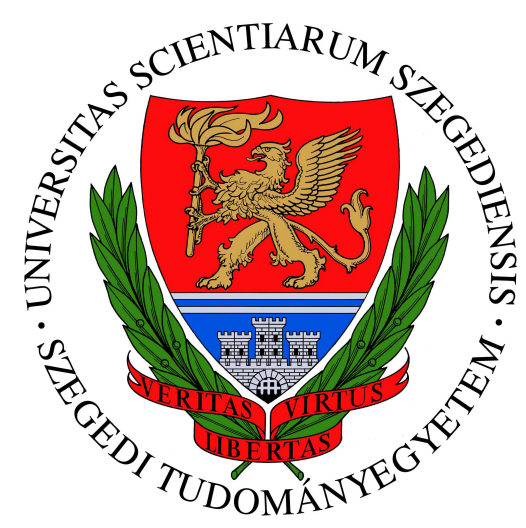

Alkalmazott és Környezeti Kémiai Tanszék

Természettudományi és Informatikai Kar

Szegedi Tudományegyetem

Szeged, 2013 


\section{Tartalomjegyzék}

$\begin{array}{ll}\text { 1. Bevezetés } & 1\end{array}$

2. Irodalmi áttekintés $\quad 3$

2.1. Termokémiai adatbázisok . . . . . . . . . . . . . . 3

2.2. Az ab initio termokémiai modellek . . . . . . . . . . . . . . . . . 4

2.2.1. Korai modellek . . . . . . . . . . . . . . . . . . . 6

2.2.2. A focal-point analízis . . . . . . . . . . . . . . . 7

2.2.3. A Weizmann- $n$ és a HEAT modellek . . . . . . . . . . . . . . . . . 7

2.2.4. Egyéb nagyobb pontosságú modellek . . . . . . . . . . . . . . . 11

2.3. A dolgozatban vizsgált gyökök és molekulák . . . . . . . . . . . . . . . . . 13

2.3.1. Légkörkémiai fontosság . . . . . . . . . . . . . . . . . 14

$\begin{array}{ll}\text { 3. Célkitüzés } & 18\end{array}$

4. Elméleti összefoglaló $\quad 19$

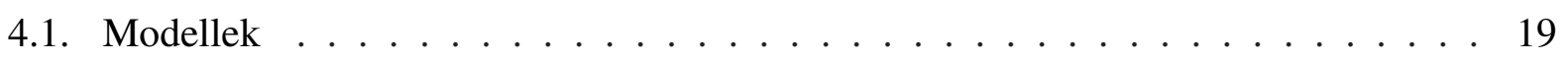

4.1.1. A focal-point modell . . . . . . . . . . . . . . . . . . 19

4.1.2. A HEAT-345(Q) modell . . . . . . . . . . . . . . . . . . 22

4.1.3. A HEAT-345+d(Q) modell . . . . . . . . . . . . . . . . . . . 25

4.2. A termokémiai adatok számítása ab initio eredményekből . . . . . . . . . . . . . . 29

4.2.1. A gázfázisú kénatom mint referenciaállapot képződéshője . . . . . . . . . 32

4.2.2. Az RRHO közelítés korrekciója . . . . . . . . . . . . . . . . 33

4.3. Az entalpia- és entrópiaértékek hibahatárai . . . . . . . . . . . . . . . . . 33

4.4. A számításokhoz használt programok, programcsomagok . . . . . . . . . . . . . 34

4.4.1. Az FPA modell . . . . . . . . . . . . . . . . . . . . . . . . 34

4.4.2. A HEAT modellek . . . . . . . . . . . . . . . . . . . 35

5. Eredmények és értékelésüik 36

5.1. Egyensúlyi geometria . . . . . . . . . . . . . . . 36

5.1.1. Konformációs analízis . . . . . . . . . . . . . . . 40

5.2. Rezgési frekvenciák és a zéruspont rezgési energia . . . . . . . . . . . . . 43 
5.2.1. FPA modell . . . . . . . . . . . . . . . . . . . . . 43

5.2.2. HEAT modellek . . . . . . . . . . . . . . . . 43

5.3. Nemrelativisztikus energia a $\operatorname{CCSD}(\mathrm{T})$ elméleti szintig . . . . . . . . . . . . 44

5.3.1. FPA modell . . . . . . . . . . . . . . . . . . . . . . 45

5.3.2. HEAT modellek . . . . . . . . . . . . . . . . . 46

5.4. Magasabb rendû korrelációs korrekciók . . . . . . . . . . . . . . 51

5.4.1. FPA modell . . . . . . . . . . . . . . . . . . . 51

5.4.2. HEAT modellek . . . . . . . . . . . . . . . . . 53

5.5. További korrekciók . . . . . . . . . . . . . . . . . . 55

5.5.1. Skaláris relativisztikus hatások . . . . . . . . . . . . 55

5.5.1.1. FPA modell . . . . . . . . . . . . . . . . . 55

5.5.1.2. HEAT modellek . . . . . . . . . . . . . . 55

5.5.2. Diagonális Born-Oppenheimer korrekció . . . . . . . . . . . 56

5.5.2.1. FPA modell . . . . . . . . . . . . . 56

5.5.2.2. HEAT modellek . . . . . . . . . . . . . . . . . 57

5.6. Végeredmények 0 és 298.15 K-en . . . . . . . . . . . . . . . . 58

5.6.1. FPA modell . . . . . . . . . . . . . . . . . . . . . . 58

5.6.2. HEAT modellek . . . . . . . . . . . . . . . . . 58

5.6.3. A kéntartalmú vegyületek tesztmodelljei . . . . . . . . . . . . . . . . . 59

5.7. Termodinamikai függvények . . . . . . . . . . . . . 63

5.7.1. Formaldehid . . . . . . . . . . . . . . . 63

5.7.2. A formaldehid származékai . . . . . . . . . . . . . 65

5.7.3. Kéntartalmú származékok . . . . . . . . . . . . . . . . 78

5.7.4. Referenciaként történő felhasználásra javasolt adatok . . . . . . . . . . . 91

6. Összefoglalás $\quad 92$

$\begin{array}{ll}\text { 7. Summary } & 96\end{array}$

$\begin{array}{ll}\text { Köszönetnyilvánítás } & 100\end{array}$

$\begin{array}{ll}\text { Irodalomjegyzék } & 101\end{array}$

$\begin{array}{ll}\text { Függelék } & 118\end{array}$ 


\section{A dolgozatban alkalmazott gyakoribb rövidítések}

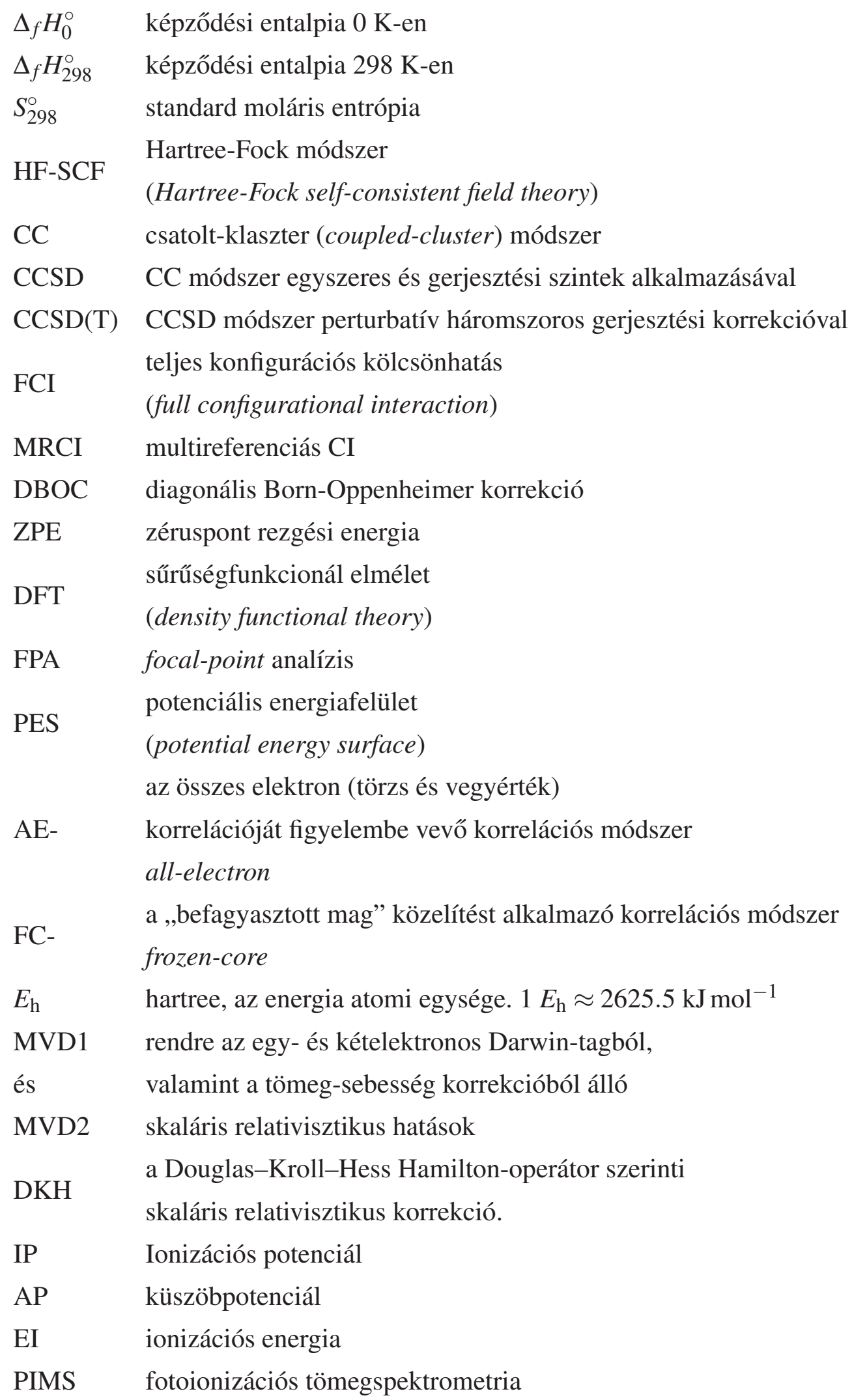




\section{Bevezetés}

Az elmúlt néhány évtizedben kiéleződött a versengés az elméleti és kísérleti termokémia között az egyre pontosabb, egyre kisebb bizonytalansággal rendelkező referenciaadatok közléséért. Az egyik ilyen kulcsfontosságú adat a kémiai szpécieszek (atomok, molekulák, szabadgyökök és ionok) standard képződési entalpiája. Emellett természetesen más paraméterek, mint az entrópia, a szabadentalpia vagy a kémiai reakciók különböző termodinamikai függvényei is fontos szerepet játszanak pl. légköri folyamatok modellezésében, technológiai folyamatok tervezésében, illetve általánosan az anyagok kémiai viselkedésének megértésében.

A kísérleti módszerek közül a legpontosabb adatokat a különféle spektroszkópiai módszerek szolgáltatják. ${ }^{1,2}$ Gyakran azonban még a legkiválóbb technikákkal meghatározott entalpiaértékek pontossága is megkérdőjelezhető. Jó példa ilyen kivételre az OH gyök experimentális képződéshő$\mathrm{je}^{3}$; vagy a pentán molekula konformációs tulajdonságainak Raman-spektroszkópiás vizsgálata, ${ }^{4}$ ahol az xg jelölésû ekvivalenciaosztályba ${ }^{5-7}$ tartozó konformerek a kísérletek során gyakorlatilag nem bizonyultak mérhetőnek annak ellenére, hogy létezésük elméleti módszerekkel egyértelmúen bizonyított. 5,8,9 További problémát jelent a nagy reaktivitással és/vagy rövid élettartammal bíró nyílt vagy zárt héjú gyökök és molekulák kísérleti kezelése. A pontosság növelésével a mérések egyre bonyolultabbá, esetenként kivitelezhetetlenné válhatnak, és világszerte mindössze néhány laboratóriumnak van lehetôsége referenciaként használható termokémiai adatok előállítására.

A rendelkezésünkre álló megfelelő technikai háttér maximális kihasználásával a hullámfüggvényalapú kvantumkémiai módszerek olyan (relatív) energiaértékeket szolgáltatnak, melyek pontossága sok esetben vetekszik a spektroszkópiai adatokéval. ${ }^{10,11}$ Azonban a többatomos rendszerek spektroszkópiai mérésének pontossága elméletileg $1 \mathrm{~cm}^{-1}$ alatt van, ami a legszofisztikáltabb ab initio módszerekkel is csak komoly erőfeszítések árán érhető el. Mindazonáltal a kísérletek során is ritka az ilyen nagy pontosság elérése, általában ennél egy nagyságrenddel nagyobb bizonytalanság jelentkezik a méréseknél. Számítási szempontból szintén problémát jelent a sokatomos rendszerek pontos kezelése. Látni fogjuk, hogy a gyököt vagy molekulát felépítő atomok, illetve végső soron az elektronok számának növekedésével, az alkalmazható elméleti szintek kiválasztásában kompromisszumos megoldásokra kényszerülünk: a rendszer méretének növekedésével ugyanis csökkentenünk kell a számítások elméleti szintjét, esetleg újabb közelítéseket kell beépítenünk a leíráshoz használt modellünkbe. Természetesen az elméleti szint csökkentése az eredmények bizonytalanságának növekedésével jár együtt, azaz a számított eredményeink becsült hibája nőni fog. Mindezek 
ellenére - az alkalmazott módszer megfelelő kiválasztása mellett - a magasabb szintú elméleti kémiai modellek megbízható, referenciaként használható termokémiai paramétereket szolgáltatnak.

Termokémiai vonatkozásban mindenképpen említésre méltóak a hálózatelméletet és az aktív adatbázisok koncepcióját együttesen alkalmazó módszerek, mint a Ruscic-féle $\operatorname{ATcT}^{12}$ vagy a Császár-féle NEAT ${ }^{13}$ termokémiai táblázatok. Talán ezek az aktív adatbázisok szolgáltatják a legpontosabb és legkonzisztensebb adatokat. ${ }^{14}$ Szem előtt kell tartanunk azonban, hogy pontosságuk éppen annyira jó, amennyire azoké az adatoké, amelyekből felépülnek. Éppen ezért mindenképpen szükség van a képződési entalpiák és más termodinamikai, valamint reakciókinetikai paraméterek pontos kísérletekből és/vagy magas szintú elméleti számításokból származó értékeire.

A kvantumkémiai módszerek nagyléptékú fejlődése, kiegészülve a számítástechnikában végbement óriási forradalommal, megdönteni látszik azt a feltevést, miszerint az elméleti kémiához szükséges referenciaadatok kísérleti eredményekből származnak. A későbbiekben bemutatjuk, hogy egyes esetekben a helyzet éppen fordított: az elméleti úton számított termokémiai és spektroszkópiai adatok pontossága sokszor felülmúlja a kísérletiekét, és így az előbbiek ismeretében az utóbbiak szorulnak revideálásra.

A komplex fejlődésnek köszönhetően nemcsak a számítások pontosságának javítása, hanem az elméleti úton kezelhető kémiai rendszerek méretének növelése is lehetôvé vált. A magas elméleti szintû elektronkorrelációs módszerek effektív használatán alapuló, ésszerúen felépített ab initio modellekkel rendkívül pontos, referenciaként használható termokémiai adatok számíthatók olyan nagyobb rendszerekre, amelyekre korábban nem volt lehetőség. Ilyen a benzol képződéshője, ${ }^{15}$ de példaként említhetjük a bután, ${ }^{16,17}$ valamint a pentán ${ }^{18}$ rotációs izomerjei közötti entalpiakülönbségek elméleti úton számított nagy pontosságú eredményeit is. 


\section{Irodalmi áttekintés}

\subsection{Termokémiai adatbázisok}

A termokémiai adatbázisokat - a különböző termokémiai mennyiségek elsődleges forrásait - felépítésüket tekintve alapvetően két fő csoportra oszthatjuk: szekvenciális és hálózatos adatbázisok. A szekvenciális adatbázisok általában olyan részletgazdag táblázatok, melyekben az elsődleges adat a kérdéses szpéciesz képződési entalpiája, de gyakran tartalmaznak más termokémiai, illetve reakciókinetikai paramétereket is. A leggyakrabban előforduló néhány ilyen kiegészítő mennyiség a hőmérsékleti korrekció, a képződési szabadentalpia, az integrált hőkapacitás vagy a standard képződési entrópia, valamint a reakciókinetikai adatok közül a molekula vagy gyök fontosabb reakcióira vonatkozó sebességi állandók és Arrhenius-paraméterek. A referenciahőmérséklet leggyakrabban a standard 298.15 K és/vagy 0 K, az ezektől különböző hőmérsékletre érvényes adatok az esetenként rendelkezésre álló hőkapacitásokból és a hőmérsékleti korrekciókból számíthatók. A leggyakrabban használt szekvenciális táblázatok az NIST-JANAF ${ }^{19}$ táblázatok, a JPL adatbázis, ${ }^{20}$ a CODATA, ${ }^{21}$ a Burcat-féle gyújtemény ${ }^{22}$ vagy az interneten ingyenesen hozzáférhetô NIST Chemistry Webbook. ${ }^{23}$

A szekvenciális táblázatokban listázott elsődleges mennyiségek kétféleképpen csoportosíthatók aszerint, hogy értékük függ-e vagy független más anyagok adataitól. ${ }^{12}$ Amennyiben függô mennyiségről van szó, akkor ,anyag-függő”, ellenkező esetben ,anyag-specifikus” információról beszélünk. A szekvenciális felépítés az utóbbi, egymástól független mennyiségek áttekinthető kezelését preferálja, az ,anyag-függő” információk estenként igen bonyolult rendszerét nehezen vagy egyáltalán nem kezeli. A szekvenciális tulajdonság tulajdonképpen azt jelenti, hogy a táblázatokba lépésről-lépésre építünk be egy-egy újabb adatot, majd az „,anyag-függő” információk közötti frissítést az egész táblázat naprakészre hozatalával végezzük. Az újabb adatok beépítése ilyen módon lassú és nehézkes, sôt, egyes esetekben megoldhatatlan problémát jelenthet.

A legelterjedtebben használt szekvenciális adatbázisok elsődlegesen kísérleti adatokra épülnek, melyek sokszor jelentős hibával terheltek, illetve régi, megbízhatatlan mérési módszerek sok esetben helytelenül kiértékelt eredményeiből származnak. Az újabb táblázatok, mint a JPL vagy a Burcat-adatbázis azonban már gyakran táplálkoznak elméleti úton számított mennyiségekből, hangsúlyozva az ilyen módon meghatározott értékek jelentôségét és megbízható felhasználhatóságát. Az elméleti kémiai számításokból származtatott eredmények rendkívül részletes adatbázisa, az 
NIST Computational Chemistry Comparison and Benchmark Database (CCCBD) gyújteménye ${ }^{24}$ szintén ingyenesen hozzáférhető, jól szerkesztett tudástár.

A termokémiai adatbázisok hálózatos képviselői közül mindenképpen említésre méltóak a Ruscic által fejlesztett ATcT, ${ }^{12}$ valamint a Császár és munkatársai által kidolgozott NEAT ${ }^{13}$ aktív hálózatos táblázatok. A legalapvetőbb különbség a két gyújtemény között az, hogy míg az ATcT kísérleti, addig a NEAT számított termokémiai adatokból, elsôsorban atomizációs energiákból, képződési entalpiákból, illetve reakcióhőkből építkezik. A hálózatos kezelés alapja, hogy az „anyag-függő” információk hálózatot alkotnak, amit termokémiai hálózatnak (TN, thermochemical network) nevezünk. Egy-egy TN különbözô, kémiai reakciókon keresztül összefüggésbe hozható anyagok ismert vagy ismeretlen képződési entalpiáit, valamint a kémiai folyamatokra vonatkozó termokémiai paramétereket tartalmazza. Fontos, hogy a TN-ben definiált reakciók adatai kíserletből (ATcT) vagy ab initio számításokból (NEAT) ismertek. A hálózatból egy-egy vektor szerint felírhatjuk az ismert és az ismeretlen termokémiai paramétereket, valamint elkészítünk egy általában ritka mátrixot, ami tulajdonképpen a TN reakcióinak megfeleltethetô sztöchiometriai mátrixszal ekvivalens. Ezzel egy túlhatározott lineáris egyenletrendszerhez jutunk, melyet a súlyozott lineáris legkisebb négyzetek módszere szerint megoldva jutunk az ismeretlen termokémiai adatokhoz. Az eljárás során a számított képződési entalpiákhoz vagy éppen atomizációs energiákhoz jól definiált hibahatár is megadható. A hálózatos adatbázisok vitathatatlan előnye, hogy amennyiben a betáplált ismert termokémiai paraméterek megfelelóen pontosak, akkor az adott hálózaton belül nagy pontosságú, konzisztens adatok nyerhetők. Érdemes megjegyezni, hogy az egyébként szekvenciális felépítésú táblázatok is tartalmazhatnak kisebb TN-eket.

\subsection{Az ab initio termokémiai modellek}

A számításos elméleti kémia az elmúlt néhány évtizedben nélkülözhetetlen eszközzé vált kisebb rendszerek - mind nyílt héjú szabadgyökök, mind zárt héjú molekulák - termokémiai függvényeinek tanulmányozásában. Az ún. kompozit $a b$ initio termokémiai modellek fejlesztésében Petersson és csoportja a CBS- $n$ (complete basis set), ${ }^{25-29}$ míg Pople és munkatársai a Gaussian- $n^{30-33}$ módszerekkel vitathatatlanul úttörő munkát végeztek.

A kompozit modellek tulajdonképpen azon a koncepción alapulnak, hogy a számított teljes energia különböző hozzájárulásai más-más elméleti szinten érnek el konvergenciát és additíven kezelhetők. A pontosság növelésének érdekében néhány modell, főleg a koraiak, empirikus korrekciós tagokat is alkalmaznak, melyek leggyakrabban pontos kísérleti eredményekhez történő illesztésekből származnak. A legpontosabb és legmodernebb módszerek azonban már nem tartalmaznak ilyen paramétereket: a teljes energia minden hozzájárulását kizárólag elméleti számításokkal határozzák meg. Érdemes megjegyezni, hogy amennyiben a termokémiai adatot egy adott molekula különböző konformerei közötti különbségként állítjuk elő, azaz a konformerek közötti entalpiakülönbséget számítjuk, akkor - egy közelmúltban megjelent állítással szemben ${ }^{34}$ - az empirikus 
korrekciókat tartalmazó módszerek is ab initio-nak tekinthetők. Az illesztett paraméterek értéke ugyanis csupán a vegyértékelektronok számától függ, a molekulageometriától azonban független, így az energiakülönbségek számításakor ezek kiejtik egymást.

Az újabb ab initio termokémiai modellek az iteratív egyszeres, kétszeres és perturbatív háromszoros gerjesztési szintú csatolt-klaszter [coupled-cluster, $\operatorname{CCSD}(\mathrm{T})$ ] módszeren alapulnak, melyet a kvantumkémiai irodalom ,aranystandard”-ként (,,golden standard” of quantum chemistry) jegyez. Az egyes esetekben a kísérleti adatokét is felülmúló pontosságot extrapolációs formulákkal illetve további korrekciók figyelembevételével érhetjük el. Ilyen korrekciók lehetnek a skaláris és egyéb, többkomponensû relativisztikus effektusok, a diagonális Born-Oppenheimer korrekció, a harmonikus zéruspont rezgési energia anharmonikus korrekciója, a coupled-cluster (CC) kezelés magasabb rendú gerjesztési szintjeinek hozzájárulása vagy a törzselektronok korrelációs tulajdonságainak explicit figyelembevétele a számításokban.

Nyilvánvaló, hogy az ab initio termokémiai modellek többsége, fôleg az általános alkalmazhatóságra fejlesztett „fekete dobozként” múködőek, ritkán használhatók teljesen tetszőlegesen, bármilyen gyök- vagy molekulacsalád esetén. Az elektronszerkezet komplexitása, ezáltal az elméleti leírhatóság bonyolultsága rendkívül változatos tulajdonság, melynek különféle hatásai már atomi szinten is érzékelhetőek. Azaz a periódusos rendszerben más és más módszerek szükségesek a különböző sorokban szereplő elemek pontos elektronszerkezeti leírásához, más és más effektusok dominálnak, valamint más és más elhanyagolások alkalmazhatóak. Hasonló megfontolások érvényesek a molekulaméret növekedését illetôen. A fentiek tekintetében egyértelmú, hogy a modelltervezés legtöbbször csak egy korlátozott számú, kémiai tulajdonságaiban hasonló szpécieszt tartalmazó csoportra végezhetô, amelyen belül a modellünkben szereplő közelítések és elhanyagolások helyessége, valamint a számítások kivitelezhetősége együttesen teljesül. Többek között ennek köszönhető a legkülönfélébb megfontolásokon alapuló elméleti termokémiai modellek viszonylag nagy száma.

Érdekes és intenzíven vizsgált probléma a képződési entalpiák számításának bázisa. A legtöbb elméleti kémiai modell atomizációs energiákat számol, ami tulajdonképpen annak a reakciónak az entalpiáját jelenti, melyben a molekula összes kötése felszakad. Az atomizációs energiákból a kérdéses képződési entalpia az atomi képződéshők ismeretében a Hess-tételből egyszerúen számítható. Az atomokra vonatkozó adatok általában nagyon pontos kísérleti eredmények, az ezekből származó hiba legtöbbször elhanyagolható. Pontosabb eredményeket szolgáltatnak az olyan, akár hipotetikus reakciók entalpiájából számított képződéshők, melyek során a reaktánsokban és a termékekben a kémiai kötések száma és kvalitatív típusa (egyszeres, kétszeres, stb.) megegyezik. Ezeket izodezmikus reakcióknak nevezzük. Ezeken kívül számos más, hasonló szabályszerúségen alapuló reakciósémát is kidolgoztak ${ }^{35}$ pontos termokémiai alkalmazásokhoz.

A jelen munkában is alkalmazott módszer, mellyel az atomi képződési entalpiák használata - néhány kivételtől eltekintve - mellózhetô, az elemekből történő képződési reakciókon alapuló számítás. Ekkor a reaktánsoldalon a molekulát alkotó elemeket, míg a termékoldalon a vizsgált 
szpécieszt szerepeltetjük. A kérdéses entalpiaérték közvetlenül adódik az alapállapotú termékoldal és az alapállapotú reaktánsoldal közötti energiakülönbségből. Az eljárás első közelítésben nyilvánvalóan nem igényel kísérletből származó paramétert, azonban az alapállapotú elemekre történő számítás nem minden esetben egyértelmú, s ilyenkor az atomi képződéshők használatára kényszerülünk. Ilyen eset a dolgozatban is szereplő szén és kén elemi alapállapota, hiszen az elsô esetben a grafitra, míg utóbbiban az $\mathrm{S}_{8}$ molekulára, mint elemi állapotra kellene ab initio számításokat végezni, ami azokon a magas elméleti szinteken, amelyeken a legtöbb modern termokémiai modell dolgozik, lehetetlen. A probléma megoldása, hogy minden olyan esetben, ahol az elemi állapot számítása egyértelmú, ott ezt az állapotot fogadjuk el referenciának, ahol pedig nem, ott az atomi képződési entalpiák kerülnek felhasználásra. További bonyodalmat okozhat, pontosan a szénatom $^{36,37}$ és a kénatom esetén is, hogy a rendelkezésre álló kísérleti adatok hibásak és értékük revideálásra szorul.

Az atomizációs és az elemi képződési reakciók bázisán történő entalpiaszámítás további részleteit példákon keresztül a 4.2 fejezetben tárgyalom.

A következő néhány pontban röviden összefoglalva bemutatom a legelterjedtebben használt modelleket, nagyobb hangsúlyt fektetve a CC módszeren alapuló, pontosabb adatokat szolgáltató protokollokra.

\subsubsection{Korai modellek}

A CBS- $n$ és a Gaussian- $n$ elméleti kémiai modellek talán a legismertebb és legszélesebb körben alkalmazott módszerek közé tartoznak. Az első modellek, a CBS-I ${ }^{25}$ és a Gaussian-1 (G1), ${ }^{30} 1989$-es születésük óta jelentôs fejlesztéseken, módosításokon mentek keresztül. A modellek célja kezdetben disszociációs energiák, ionizációs potenciálok, reakcióhők, képződési entalpiák és más termokémiai mennyiségek kb. $10 \mathrm{~kJ} \mathrm{~mol}^{-1}$-es pontosságú számítása volt. A Gn modellek széleskörú elterjedését elősegítette azok „fekete dobozként” történő implementálása a kereskedelmi forgalomban hozzáférhető Gaussian programcsomagba. A legújabb G09 ${ }^{38}$ verzióban elérhető G4 modell ${ }^{33}$ a G03/05 tesztkészlet ${ }^{39}$ kísérleti adatait $3.47 \mathrm{~kJ} \mathrm{~mol}^{-1}$-es átlagos abszolút devianciával adja vissza.

A fejlesztések során nagy számú, rendkívül változatos módosított verzió látott napvilágot mind a CBS, mind a Gn modellekhez. Ezek a protokollokban figyelembe vett különböző elektronkorrelációs hozzájárulások, a számítások bázisául szolgáló molekulageometria, valamint ezen keresztül a harmonikus rezgési frekvenciák, azaz tulajdonképpen a zéruspont rezgési korrekció meghatározásához használt elméleti szintekben különböznek. Utóbbiakat az újabb modellekben általában valamilyen sưrúségfunkcionál módszerrel számítják, melyek nem minden estben szolgáltatnak megbízható eredményt. ${ }^{40,41}$ Mindezek ellenére a $\mathrm{G} n$ modellek a mai napig népszerúek és elterjedten használtak. Nagy előnyük, hogy a rendelkezésre álló sokféle módosított változataik miatt szinte az összes molekulacsaládra alkalmazhatóak, akár nagyobb, több tíz, esetleg száz atomot tartalmazó rendszerek esetén is. Sôt, létezik olyan modell is, melyet reakciókinetikai paraméterek elméleti 
számítására dolgoztak ki. ${ }^{42}$

\subsubsection{A focal-point analízis}

A focal-point ${ }^{43,44}$ analízis (FPA) egy általános, a felhasználó által átgondolt és ésszerúen felépített sémán alapuló modell, melyet eredetileg nagyfelbontású molekulaspektroszkópiai számításokhoz dolgoztak ki a 90-es évek elején. Mivel a módszer kiválóan alkalmas nagy pontosságú relatív energiakülönbségek számítására, így használata a termokémiában gyorsan elterjedt és kidolgozása óta számos kisebb molekuláris rendszer esetén alkalmazták referenciaadatok előállítására. ${ }^{14,45,46} \mathrm{~A}$ számítási módszer alapvetően egy kompozit modell, mely több hozzájárulás összege szerint közelíti a teljes nemrelativisztikus elektronenergiát, melyet egyéb korrekciókkal kiegészítve juthatunk a végsố eredményünkhöz. Ehhez egy kétdimenziós extrapolációs rácsot definiálunk, ami tulajdonképpen különválasztja az egyes hozzájárulások számítása során alkalmazott egy-és többelektronos elméleti kémiai módszereket. Az egy- és többrészecske problémák pontos kezeléséhez extrapolációs formulákat alkalmaz és fontos tulajdonsága, hogy a korrelációs kezelés során nem fagyasztja be a törzselektronokat, azaz a korrelációs kezelésben explicite figyelembe veszi azok vegyértékelektronokkal történő kölcsönhatásait is.

Az FPA legnagyobb előnye a rugalmassága. Filozófiájának megfelelően a módszer kerüli a szigorúan felépített lépéssorozatból álló séma definiálását, egyszerúen az elméleti és a gyakorlati lehetőségek határáig bővíti a benne szereplő hozzájárulások elméleti kezelését, hogy biztosítsa azok megfelelő konvergenciáját. Ez nyilvánvalóan a rendelkezésre álló hardveres és szoftveres erőforrások maximális kihasználását jelenti.

Az előbbiekből kézenfekvően következik, hogy az FPA kezelés során kapott eredményeink kiértékelésekor nagy hangsúlyt fektetünk külön-külön minden egyes hozzájárulás konvergenciatulajdonságának vizsgálatára. Azon túlmenően, hogy ilyen módon a végeredményeinkhez többékevésbé jól definiált és pontos hibát becsülhetünk, információval is szolgálhatunk annak legvalószínúbb forrásairól. ${ }^{47}$

A formaldehid képződéshőjének focal-point analízisével, illetve annak részletes elméleti hátterével a 4.1.1 fejezet foglalkozik.

\subsubsection{A Weizmann- $n$ és a HEAT modellek}

Hasonló filozófiájuk, felépítésük, valamint pontosságban kitúzött céljuk miatt a Weizmann- $n$ $(\mathrm{Wn})^{48-50}$ és a HEAT ${ }^{51-53}$ (high-accuracy extrapolated ab initio thermochemistry) protokollokat érdemes együtt tárgyalni. Mindkét termokémiai modellcsalád képviselői többé-kevésbé a „fekete doboz" módszerek közé sorolhatók, viszont a Gn és CBS- $n$ módszereket jellemző szigorú protokolláris tulajdonság mégsem teljes mértékben igaz rájuk. Flexibilitásuk azonban jóval alulmarad az FPA módszerhez képest. A kérdéses modellek kompozit módszerek, azaz a vizsgált rendszer teljes energiáját ezek is különböző, additíven kezelhető hozzájárulásokra bontják. Az összegben 
figyelembe vett tagok számításához használt elméleti szintek, az ezekhez alkalmazott bázisok és más tulajdonságok csekély vagy jelentős mértékú perturbációjával a modellek számos verziója látott napvilágot, melyek egy része a nagyobb pontosságra, más része a kisebb számítási igényre törekedett. A Wn családnak összesen több mint 10 képviselője ismert.

A Wn modellek fejlesztése a W1 és W2 módszerekkel indult, és az első olyan termokémiai protokolloknak tekinthetôk, melyek a Gn és CBS- $n$ modellekkel ellentétben, tisztán elméleti úton, empirikus korrekciók használata nélkül dolgoznak. A fejlesztôk kezdeti célja egy olyan (,fekete doboz”) módszer kidolgozása volt, mellyel legalább hat nehézatomot tartalmazó rendszerek atomizációs energiáját lehet becsülni legfeljebb $1 \mathrm{~kJ} \mathrm{~mol}^{-1}$ hibahatáron belül, de a bizonytalanság bonyolultabb rendszerek esetén sem haladhatja meg a kémiai pontosság körülbelül $4 \mathrm{~kJ} \mathrm{~mol}^{-1}$-es értékét. ${ }^{* 54}$ Kísérleti, vagy azzal bármilyen módon összefüggésbe hozható adat kizárólag a modell ellenőrzési szakaszában jelenhet meg, de a termokémiai paraméterek számítása során nem. Fontos kérdés volt a kidolgozott módszer protokolláris volta, tulajdonképpen az, hogy szükséges esetekben a kompozit modell egyes hozzájárulásainak számítási módja változtatható-e vagy sem. ${ }^{54} \mathrm{~A}$ kérdés ugyan a hivatkozott 54 referenciában nyitott maradt, azonban a későbbiekben a módosított modellek pontosan ilyen változtatások eredményeként jöttek létre.

A család későbbi képviselői, különösen a legújabb W4 modell ${ }^{50}$ és ennek különböző módosított verziói, már a sokkal nehezebben megvalósítható szub-kJ mol ${ }^{-1}$-es pontosságot túzték ki célul. A módosítások nélküli, eredeti W4 modell átlagosan akár $0.5 \mathrm{~kJ} \mathrm{~mol}^{-1}$-es hibával képes atomizációs energiák számítására, míg az ennél is pontosabb W4.4 számítások ${ }^{55}$ átlagos négyzetes közepes eltérése az ATcT adatoktól mindössze $0.2 \mathrm{~kJ} \mathrm{~mol}^{-1}$. Természetesen az ilyen pontossággal dolgozó modellek komoly számítógépes hátteret igényelnek, és csak kisebb, legfeljebb 4-5 nehézatomot tartalmazó molekulák esetén alkalmazhatók.

Ugyan a HEAT és a Wn módszerek felépítése hasonló, mégis egy hozzájárulás számításában jelentősen eltérnek: míg a Wn a korrelációs kezelés során a befagyasztott mag közelítést (FC, frozen-core) alkalmazza, addig a HEAT az összes törzs- és vegyértékelektront együttesen figyelembe veszi a számításokban. Az elektronok ilyen módon történô szeparációja az atomizácós energiák esetén legfeljebb $0.5 \mathrm{~kJ} \mathrm{~mol}^{-1}$-es hibát eredményezhet, ami elemi képződési vagy izodezmikus reakciókból számított képződési entalpiák esetén várhatóan még kisebb. ${ }^{53}$ Látható, hogy a bizonytalanság gyakorlatilag elhanyagolhatóan kicsi, főleg ha figyelembe vesszük a számítási igény jelentôs csökkenését is, mégis, a szub-kJ mol ${ }^{-1}$-es pontosságot célzó számításokban érdemes kerülni az elektronok régiók szerinti különválasztását.

Egy másik fontos probléma és jelentős hibaforrás, az egyes járulékok megfelelő mértékú konvergenciájának biztosítása. Több elméleti tanulmány ${ }^{47,53,56}$ is bizonyítja, hogy fôleg a HF-SCF energia, de az MP2 (másodrendú Møller-Plesset perturbációs módszer), a CCSD, és CCSD(T) korrelációs hozzájárulások háromszoros- $\zeta$ (TZ) minôségú bázisokkal kapott eredményei olyan tá-

*A kémiai pontosság definíció szerinti értéke $1 \mathrm{kcal} \mathrm{mol}^{-1}=4.184 \mathrm{~kJ} \mathrm{~mol}^{-1}$. 
vol vannak a konvergenciától, hogy az extrapolációs formulákban történő alkalmazásuk komoly hibát okozhat. Olyannyira, hogy sok esetben célszerúbb inkább a legmagasabb bázissal számított adatot felhasználni a TZ bázison alapuló extrapolált eredmény helyett. ${ }^{53}$ A HEATIII, illetve az 52 referenciában bevezetett és jelen munkában is átvett rövidítés szerint a HEAT-456n módszerek éppen ezt a hibát igyekeznek csökkenteni, oly módon, hogy a módszer elnevezésében is szereplő 4-, 5- és 6-szoros- $\zeta$ bázissal kapott HF-SCF, illetve az 5- és 6-szoros- $\zeta$ CCSD(T) járulékok extrapolációjával dolgozik. Természetesen egyes esetekben még az ezekkel a nagy bázisokkal kapott eredmények sem feltétlenül érik el a kívánt konvergenciát. ${ }^{47,56}$ Az ilyen problémák megoldása egyrészt a bázistervezés és -optimalizálás problémáját veti fel, másrészről olyan elektronkorrelációs módszerek alkalmazását követeli meg, melyek a tradicionális megfelelőikhez képest gyorsabb és jobb konvergenciát mutatnak a növekvő számú bázisfüggvényekkel. Az utóbbi módszerek az R12 vagy F12 rövidítésekkel jelölt explicit módon korrelált (explicitly correlated) módszerek, 57,58 melyek a dinamikus elektronkorreláció kezelése során a hullámfüggvényben explicite figyelembe veszik az elektron-elektron távolságot. A hagyományos korrelációs módszerekben ugyanis egyrészecske függvények antiszimmetrizált szorzatát (Slater-determinánsok) használjuk, amivel kisebb elektron-elektron távolságoknál rossz közelítését kapjuk az egzakt hullámfüggvénynek. Az így számított energia hibája a bázisfüggvénnyel $(\ell+1)^{-3}$ szerint csökken, ahol $\ell$ a bázisban szereplő legnagyobb függvényhez tartozó impulzusmomentum-kvantumszám. Az elektron-elektron távolság hullámfüggvénybe történő explicit bevezetésével ez a függés $(\ell+1)^{-7}$-re változik. ${ }^{58}$

A dinamikus korrelációs hatások kezelése a modern elméleti modellekben, ahogyan azt már említettük, a CCSD(T) módszeren alapul, ahol a (T) korrekció egy perturbációszámításból származó tag. Az esetek többségében, noha ez függ a referencia hullámfüggvénytől is, az ezen a szinten számított járulékok igen nagy pontosságúak, amennyiben megfelelően nagy bázisfüggvényeket és az ezekre épülő extrapolációs formulákat együttesen használjuk. Azonban a CC sorfejtés viszonylag gyors levágása az egyszeres és kétszeres gerjesztési szinteknél jelentôs hibát okozhat olyan esetekben, ahol fontos szerepet játszanak a korrelációs hatások. A pontosság és a kompozit modellben a korrelációs járulék megfelelő konvergenciájának biztosítása érdekében a kevésbé bonyolult esetekben is érdemes foglalkozni az ún. magasabb rendú korrelációs hozzájárulásokkal. Ezek a CC módszerben a háromszoros, négyszeres, ötszörös, stb. gerjesztési szintek figyelembevételét, valamint ezek mellett vagy ezeket kiegészítve a megfelelő szintû́ perturbatív $(\mathrm{Q}),(\mathrm{P})$, stb. korrekciókkal történő számítást jelentik. A Kállay Mihály által fejlesztett MRCC kód ${ }^{59}$ éppen az ilyen tetszőleges gerjesztési szintű CC korrekciók számítását teszi lehetővé. ${ }^{60-62}$

Számos elméleti munka foglalkozott a CCSD(T)-nél magasabb korrelációs tagok hozzájárulásával, annak mértékével és főleg az egyrészecske bázissal való konvergenciájával. ${ }^{49,55,63-66}$ Nyilvánvaló, hogy egy adott rendszer esetén minél magasabb a gerjesztési szint, annál kisebb az alkalmazható bázisfüggvények száma. Szerencsére - a problémás esetektôl eltekintve - általában igaz, hogy a magasabb rendú CC számítások gyors konvergenciát mutatnak a bázissal, és az FC közelítés sem okoz olyan mértékú hibát, mint a CCSD vagy CCSD(T) kezelések során, noha ez nem 
minden esetben teljesül. $\mathrm{A} \mathrm{Cl}_{2}$ molekula disszociációs energiájához ${ }^{47}$ a törzselektronok bevonása a CCSDT(Q) számításokba $0.15 \mathrm{~kJ} \mathrm{~mol}^{-1}$-es járulékot ad, ami a vegyérték régió $2.35 \mathrm{~kJ} \mathrm{~mol}^{-1}$-es hozzájárulásához képest jelentősnek tekinthető.

A CCSDT szintnél magasabb rendú korrelációs tagok bázisfüggvénnyel való konvergenciájának vizsgálata során Ruden és csoportja, ${ }^{66}$ valamint Boese ${ }^{49}$ és munkatársai a teljes négyszeres gerjesztési szintű CCSDTQ hozzájárulásokat vizsgálták kis molekulák atomizációs energiájához. A kérdéses tag gyors konvergenciát mutatott, gyakorlatilag már a cc-pVDZ készlettel konvergált, az ennél nagyobb bázissal tapasztalható energiaváltozás gyakorlatilag elhanyagolható volt. Ezt néhány évvel késốbb Martin és csoportja is alátámasztotta, ${ }^{55}$ továbbá a $\mathrm{Cl}_{2}{ }^{47}$ és $\mathrm{F}_{2}{ }^{56}$ molekulák disszociációs energiájának számításánál is hasonló konklúziót vonhatunk le.

A perturbatív négyszeres gerjesztési szint, a CCSDT(Q) módszer használata az iteratív megfelelője helyett, a számítási idő jelentős csökkenését eredményezi, hasonlóan a CCSDT és (T) módszerek közötti különbséghez. A perturbatív tag bevezetése a HEAT protokollba a HEAT-XYZ(Q) modellt eredményezi, ${ }^{52}$ ahol XYZ jelöli a HF-SCF és CC energiák extrapolációjához használt bázisok kardinális számát. A (Q) modell sokkal lassabb konvergenciát mutat a bázissal, ${ }^{55}$ ebben az esetben a cc-pVDZ szinten számított eredmények egyáltalán nem megbízhatóak és legalább TZ minőségú bázis szükséges a megfelelő pontosság eléréséhez. Amennyiben a molekula mérete lehetôvé teszi, akkor érdemes a három- és négyszeres- $\zeta$ minőségú eredményekből extrapolációval közelíteni a végtelen bázishoz tartozó határenergiát. ${ }^{56}$

A fentiekben vázolt nemrelativisztikus tagokon felül a HEAT és a Wn modellek figyelembe vesznek további, általában kisebb hozzájárulást szolgáltató egyéb korrekciókat is. A dolgozatomban tárgyalt modellek ezen járulékaival az Elméleti összefoglaló megfelelő fejezeteiben részletesen fogok foglalkozni, de itt mégis érdemes egy átfogó, összegző képet adni a protokollok felépítésérôl. Tehát a HEAT és a $\mathrm{W} n$ modellek az alábbi pontok szerint állítják elő a vizsgált rendszer teljes energiáját, illetve ennek ismeretében a termokémiai paramétereket:

- Az egyensúlyi geometria, valamint a harmonikus rezgési frekvenciák meghatározása ab initio számításokkal vagy kísérleti eredmények felhasználásával.

- A rendszer teljes nemrelativisztikus energiájának számítása a modellben szereplő elméleti szinteknek megfelelően.

- További nemrelativisztikus korrekciók számítása, melyek a Wn és a HEAT modellek szerint az alábbiakat jelentik:

- Magasabb rendú korrelációs tagok a CC módszerben. (HEAT és Wn)

- A befagyasztott mag közelítésből származó hiba korrekciója. (Wn)

- A zéruspont rezgési energia számítása a rendelkezésre álló harmonikus frekvenciákból, valamint az ehhez tartozó anharmonikus korrekció közelítése. 
- A Born-Oppenheimer közelítés diagonális korrekciója.

- A skaláris relativisztikus hatások és a spin-pálya csatolás korrekciójának számítása.

- Az fenti eredményekből a 0 K-en érvényes termokémiai adat meghatározása.

- Statisztikus termodinamikai alapokon a véges hőmérsékletekre vonatkozó adatok meghatározása.

Az egyes pontok részletes leírását a dolgozatban használt két módosított HEAT protokoll példáján keresztül a 4.1.2 és a 4.1.3 fejezetekben mutatom be.

\subsubsection{Egyéb nagyobb pontosságú modellek}

A fentieken kívül igen nagy számú termokémiai modell található az irodalomban, melyek közül a teljesség igénye nélkül érdemes a fontosabbakat röviden áttekinteni. Jellemzően ezek is kompozit módszerek, melyek a nemrelativisztikus Born-Oppenheimer közelítésen túlmenő egyéb korrekciókat is figyelembe vesznek. A pontosság növelése érdekében a számítási igényt is szem előtt tartva egyes modellek, mint a Bakowies-féle ATOMIC ${ }^{41,67}$ vagy a Kondo és munkatársai által fejlesztett atom-, ${ }^{68}$ valamint Melius és Binkley kötésadditivitási módszerei69 (AAC és BAC), más megfontolásokat is figyelembe vesznek az elméleti szintek szisztematikus növelésén kívül. Sok esetben a protokolláris jelleg sokkal kevésbé hangsúlyozott, néhány modellt inkább egy-egy specifikus problémára, esetleg egyetlen bonyolultabb kémiai rendszerre dolgoztak ki.

Feller és munkatársai számos kompozit protokollt közöltek ${ }^{70-75}$ különböző molekulák pontos termokémiai számítására. Továbbá modelljeiken keresztül több tanulmányban ${ }^{76-79}$ is vizsgálták a nagy pontosságú kvantumkémiai módszerek lehetséges hibaforrásait kisebb molekulák abszolút és atomizációs energiáinak meghatározása esetén. Modelljeik az FC-CCSD(T) módszeren alapulnak, melyet a HEAT-hez és Wn-hez hasonlóan több más korrekcióval is kiegészítenek. A számításaikhoz a Dunning-féle korreláció-konzisztens báziskészleteket használják, melyek szisztematikus növelésével és extrapolációs formulák segítségével közelítik a végső energiát. A képződési entalpiákat általában atomizációs energiák bázisán adják meg, de létezik izodezmikus reakción alapuló eredményük is. ${ }^{70}$ Modelljeik nagy előnye, hogy többé-kevésbé jól definiált - bár sok esetben inkább optimisztikusnak mondható - bizonytalanságot is megadnak a számított adatokhoz.

Említésre méltó a Bakowies által fejlesztett ATOMIC protokoll (ab initio thermochemistry using optimal-balance models with isodesmic corrections). ${ }^{41,67}$ A modell egy kompozit sémán alapul, melyben a törzs- és vegyértékelektronokat szeparálva kezeljük, és a korrelációs járulékot MP2, CCSD és CCSD(T) részekre bontjuk, majd ezeket külön-külön extrapolálva vesszük figyelembe. A modell ugyan nem tartalmaz empirikus paramétereket, de a pontosság növelésének érdekében az atomizációs energiáit előre számított izodezmikus korrekciókkal egészíti ki. Az ATOMIC modell alkalmas akár 10-20 elsô periódusbeli atomot tartalmazó molekulák atomizációs energiájának a Gaussian-3 módszernél valamivel pontosabb becslésére. 
Az ATOMIC-kal ellentétben az $\mathrm{AAC}^{68}$ és a $\mathrm{BAC}^{69}$ módszerek kísérleti adatokhoz történő illesztéssel kapott additív empirikus korrekciókat használnak az egyébként alacsonyabb, MP2, MP4, G2, G2(MP2), stb. szinten számított termokémiai mennyiségekhez. Az alacsony elméleti szintú kezeléssel elérhető szerényebb pontosság mellett hátrányuk, hogy a különféle atomokat tartalmazó molekulákra eltérő paraméterkészleteket kell alkalmazni, ami nehezíti általános felhasználhatóságukat.

Sokkal pontosabb eredményeket szolgáltatnak az Angela Wilson és csoportja által fejlesztett korreláció-konzisztens kompozit módszerek, a ccCA protokollok (correlation consistent composite approach) ${ }^{80,81}$ Az elsô verziója a G2 és G3 módszerek alternatívájaként született, megôrizve azok „fekete doboz” jellegét, valamint alapvető felépítését is. Az eredeti modell MP2, MP4 és QCISD(T) korrelációs módszerekkel dolgozott, de a Pople-féle hasított vegyérték (split-valence) bázis helyett a korreláció-konzisztens függvényeket használta, melyre a módszer elnevezése is utal. Az egyes hozzájárulásokat az FC közelítés keretén belül extrapolálja a végtelen bázishoz tartozó eredményhez, de a módszer tartalmaz a törzselektronok korrelációs hatásaira vonatkozó korrekciós tagot is. Fontos, hogy a $\mathrm{G} n$ protokollokkal szemben a ccCA nem tartalmaz kísérleti adatokhoz történő illesztésből származó empirikus korrekciót. A későbbiekben rendkívül változatos problémákra dolgoztak ki különféle módon módosított ccCA modelleket, némileg eltávolodva a ,fekete doboz” filozófiától. Létezik a ccCA-nak alkáli- és alkáliföldfémekre, ${ }^{82}$ átmeneti állapotokra, ${ }^{83}$ kéntartalmú vegyületekre,${ }^{84}$ harmadik periódusbeli atomokat tartalmazó rendszerekre, ${ }^{85}$ 4d átmeneti fémekre, ${ }^{86}$ sốt, nagy energiatartalmú, több nitrogénatomot tartalmazó instabil szerves robbanóanyagokra, tetrazinokra kidolgozott változata is. ${ }^{87}$ A ccCA és Morokuma ONIOM ${ }^{88,89}$ modelljének ötvözésével született a ccCA-ONIOM ${ }^{90}$ protokoll, ami több tíz vagy akár száz atomot is tartalmazó rendszerek - kisebb pontosságú - elméleti kezelését teszi lehetővé. A modell multi-referenciás módszerekkel bóvített változata, az $\mathrm{MR}-\mathrm{ccCA}^{91}$ alkalmas gerjesztett állapotok, illetve egyéb egydetermináns hullámfüggvénnyel nem leírható rendszerek, pl. Si-tartalmú vegyületek termokémiai vizsgálatára. ${ }^{92}$

Ugyan alacsonyabb szinteket használ, és ezáltal pontosságban sem éri el az ab initio modelleket, mégis érdemes megemlíteni a Truhlar és csoportja által kidolgozott multikoefficiens (MC, multi-coefficient) korrelációs módszert. ${ }^{93}$ Az MC módszerek azon a technikán alapulnak, hogy a korrelációs kezelés során a sorfejtés kétszeres gerjesztéseknél történő levágásából (CISD), valamint a bázis nem teljességéből eredô hibát egy skálázófaktorral igyekszik javítani. ${ }^{94,95}$ Fontos, hogy a skálázás csak a teljes vagy csak a dinamikus korrelációs járulékra érvényes, a HF-SCF energia az eljárásban nem szerepel. Termokémiai számításokban, a korrelációs tag skálázásához hasonlóan, a teljes elektronenergia egyes hozzájárulásait külön-külön skálafaktorokkal látja el. ${ }^{93,96,97} \mathrm{~A}$ skálázófaktorok összes száma függ a kompozit modellt definiáló összegben szereplő tagoktól, azaz alacsonyabb szintek és kisebb bázisok alkalmazásával 2-4, míg magasabb szintek és nagyobb bázisok esetén akár 10 faktor is szerepelhet a modellben. A módszer módosításon is keresztülment, melyek közül legfontosabb talán a súrúségfunkcionál módszerek skálázott bevezetése a protokol- 
lokba. ${ }^{98,99}$

Végül említésre méltóak a Klopper-csoport kompozit módszerei is. ${ }^{100-102}$ A modellek atomizációs energiákat, valamint képződési entalpiákat számítanak úgy, hogy az extrapolált CCSD, CCSD(T) és CCSD[T] járulékokat az explicite korrelált CCSD-R12, CCSD(T)-R12 és CCSD[T]R12 megfelelőikre cserélik.

\subsection{A dolgozatban vizsgált gyökök és molekulák}

Doktori dolgozatomban tanulmányozott gyököket és molekulákat a 2.1. táblázatban listáztam. Kiválasztásuk többféle szempont figyelembevételével történt, de általánosan jellemző, hogy a korábban kísérletileg és/vagy elméleti úton meghatározott termokémiai paramétereik bizonytalanok, nagy hibával terheltek. A szpécieszek mindegyike fontos szerepet tölt be légkörkémiai folyamatokban, ezek közül a legfontosabbakat a 2.3.1 alfejezetben röviden összefoglalva részletezem.

2.1. táblázat

A különböző elméleti kémiai modellekkel vizsgált gyökök és molekulák

\begin{tabular}{cccc}
\hline \hline Modell & FPA & HEAT-345(Q) & HEAT-345+d(Q) \\
\hline \hline \multirow{2}{*}{$\mathrm{H}_{2} \mathrm{CO}$} & $\mathrm{F}_{2} \mathrm{CO}$ & $\mathrm{HSO}$ \\
& & $\mathrm{FCO}$ & $\mathrm{SOH}$ \\
& $\mathrm{HFCO}$ & $\mathrm{HOSO}_{2}$ \\
& $\mathrm{HClCO}$ & cisz/transz-HSNO \\
& FClCO & $\mathrm{SH}$ \\
& cisz/transz-HOCO & $\mathrm{CH}_{2} \mathrm{SO}$ \\
& $\mathrm{NH}_{2} \mathrm{CO}$ & $\mathrm{CH}_{2} \mathrm{SH}$ \\
& & $\mathrm{S}_{2} \mathrm{COH}$ \\
& & $\mathrm{SCSOH}$ \\
\hline
\end{tabular}

Az eredményeim összehasonlításához használt referenciaadatok elsődleges forrása a NASA Jet Propulsion Laboratory (JPL) ${ }^{20}$ gyújteménye volt, melyben az összes itt tanulmányozott gyök és molekula képződési entalpiája, valamint entrópiája megtalálható. Az összehasonlításhoz természetesen más adatbázisokat és a szakirodalomban fellelhető egyéb gyújteményeket, összefoglaló munkákat és egy-egy szpécieszre vonatkozó specifikus közleményeket is felhasználtam. Ezek részletes bemutatásával és összehasonlításával az 5 fejezet foglalkozik. 


\subsubsection{Légkörkémiai fontosság}

Értekezésemnek nem célja a benne szereplő gyökök és molekulák légköri reakcióinak részletes kinetikai tárgyalása. A teljesség kedvéért mégis érdemes röviden áttekinteni azokat a legfontosabb légköri kémiai folyamatokat, melyekben a szpécieszek keletkeznek, bomlanak, illetve közvetetten vagy közvetlenül felelősek a légköri ózonmennyiség csökkenéséért.

A formaldehid gyakori légköri szennyező, maximális koncentrációja ipari vagy nagyvárosi területeken meghaladhatja a 150 ppb-t. ${ }^{103,104}$ A gépkocsik kipufogógázával, ipari folyamatok melléktermékeként, illetve illékony szerves szennyezők oxidációjával kerül a troposzférába és az alsó sztratoszférába. Lévén az oxidatív $\mathrm{HO}$ és $\mathrm{HO}_{2}$ gyökök prekurzora, a formaldehid komoly hatással van a troposzféra oxidációs kapacitására. ${ }^{105}$ A hidroperoxil gyök a fotolízissel képződő formilgyök, HCO, oxigénnel történő reakciójának egyik terméke: ${ }^{103}$

$$
\begin{aligned}
& \mathrm{H}_{2} \mathrm{CO}+\mathrm{h} v \longrightarrow \mathrm{HCO}+\mathrm{H} \\
& \mathrm{HCO}+\mathrm{O}_{2} \longrightarrow \mathrm{HO}_{2}+\mathrm{CO}
\end{aligned}
$$

Természetesen a (2.1a) reakcióban keletkező atomos hidrogén $\mathrm{O}_{2}$ molekulákkal ütközve szintén $\mathrm{HO}_{2}$ gyököt képezhet. A (2.1b) folyamatban keletkező hidroperoxil gyök az esetlegesen jelenlévő NO-dal hidroxil gyököt és $\mathrm{NO}_{2}$-ot termelhet. ${ }^{103}$

A formaldehid két legfontosabb légköri reakciója éppen a hidroxil- és hidroperoxil-gyökökkel történő átalakulások. Ezek közül az első egy direkt hidrogénabsztrakció, melynek során vízkilépés mellett HCO gyök keletkezik, míg a második egy addíciós folyamat, melyben peroxi-gyök képződése feltételezhető:104

$$
\mathrm{H}_{2} \mathrm{CO}+\mathrm{HO}_{2} \longrightarrow \mathrm{CH}_{2}(\mathrm{OO}) \mathrm{OH} \text {. }
$$

Magasabb hőmérsékleteken, különösen égési folyamatokban, a fenti addíciós mechanizmus mellett a hidrogénabsztrakciós csatorna ebben a reakcióban is számottevővé válhat.

A formaldehid a Föld légkörén kívül, a világúrben is nagyobb mennyiségben előfordul. Jelenlétét elsősorban protoncsillagok közelében, csillagközi jégben, valamint az üstökösök körüli kozmikus porban mutatták ki. ${ }^{106}$

A freonokat, azaz a fluorozott és klórozott szénhidrogéneket (CFC, chlorofluorocarbon) széleskörúen alkalmazták légkondicionáló és hútőberendezésekben. Közismert tény, hogy a légkörbe kerülve ezek a vegyületek komoly ózonréteg csökkentő hatást váltanak ki. Ezért az elmúlt néhány évtizedben fokozatosan alternatív megoldásokkal próbálták kiváltani az ipari és mindennapi alkalmazásukat. Egy lehetséges alternatíva a klóratomot nem tartalmazó, fluorozott szénhidrogének (HFC, hydrofluorocarbon) használata. A HFC vegyületek közvetlenül nem felelősek az ózonréteg csökkenéséért, noha közvetetten, az oxidációs folyamataikban képződő gyökökön keresztül fogyaszthatnak légköri ózont. ${ }^{107}$ A HFC-k atmoszférikus élettartama jóval rövidebb, mint a CFC 
típusú molekuláké, mivel a légkörben viszonylag nagy mennyiségben előforduló $\mathrm{OH}$ gyökökkel történő reakciójuk során gyorsan lebomlanak. Az egy szénatomot tartalmazó, metánból levezethető HFC vegyületek ilyen oxidációs folyamataiban keletkeznek a különböző halogénezett formilszármazékok. ${ }^{107}$

A formaldehid halogénatomokkal szubsztituált származékai közül a légkörben az egyik legnagyobb mennyiségben előforduló vegyület a karbonil-difluorid, $\mathrm{F}_{2} \mathrm{CO}$. A troposzférában a molekula elsődleges forrása a fluorral szubsztituált szénhidrogének hidroxil-gyökkel történő reakciójakor képződő $\mathrm{CF}_{3}$ gyök, ami a légköri oxigénnel reakcióba lépve HF-ot és $\mathrm{F}_{2} \mathrm{CO}$-t képez. ${ }^{108}$ Ez a két termék a két legfontosabb hosszú élettartamú légköri fluorraktárként funkcionáló vegyület, melyek közül a karbonil-difluorid a középső és felső sztratoszférában dúsul, elsősorban a trópusi és a közepes hosszúsági fokú területek mentén. ${ }^{109} \mathrm{~A}$ sztratoszférába főként a $\mathrm{CF}_{2} \mathrm{Cl}_{2}$ fotolízise során keletkező $\mathrm{CF}_{2} \mathrm{Cl}$ gyök oxidációjával kerül, ${ }^{108}$ és további fotolízissel hidrogén-fluoriddá alakul. ${ }^{109}$ A molekula köztitermékként előfordul a $\mathrm{CF}_{3}$ gyök és annak különböző származékainak bonyolult légköri degradációs reakcióciklusaiban is. ${ }^{110,111}$

A karbonil-difluorid $\lambda=200-240$ nm hullámhosszúságú UV-sugárzás hatására fotolízissel fluoroformil-gyökké, FCO, alakul. ${ }^{112}$ Az ilyen hullámhossz tartományba esô sugárzás kizárólag a sztratoszféra felsőbb rétegeiben fordul elő, ezért a gyök a légkör alsóbb rétegeiben ritkán fordul elő. ${ }^{112}$ A HFC vegyületekből szintén fotolízissel felszabaduló atomos fluorral $\mathrm{F}_{2} \mathrm{CO}$-vá alakul. Legfontosabb reakciója az $\mathrm{O}_{2}$-nel történő oxidáció, mely közvetlenül hatással van a légköri ózonmennyiségre az alábbi konszekutív séma szerint: ${ }^{107}$

$$
\begin{array}{r}
\mathrm{FCO}+\mathrm{O}_{2} \longrightarrow \mathrm{FC}(\mathrm{O}) \mathrm{O}_{2} \\
\mathrm{FC}(\mathrm{O}) \mathrm{O}_{2}+\mathrm{O}_{3} \longrightarrow \mathrm{FC}(\mathrm{O}) \mathrm{O}+2 \mathrm{O}_{2}
\end{array}
$$

A formil-fluorid, $\mathrm{HFCO}$, a $\mathrm{CF}_{3} \mathrm{CH}_{2} \mathrm{~F}$ légköri bomlási folyamatának egyik végterméke. A kérdéses fluorozott szénhidrogént széles körben használták ipari alkalmazásokban, illetve légkondicionáló berendezésekben klórozott szénhidrogének helyettesítőjeként. ${ }^{113}$ Mivel a $\mathrm{CF}_{3} \mathrm{CH}_{2} \mathrm{~F}$ elsôsorban a légkör alsóbb rétegeiben dúsul, így nyilvánvalóan a formil-fluorid mennyisége is itt számottevő. A HFCO közvetlenül a $\mathrm{CF}_{3} \mathrm{CHFO-gyök} \mathrm{fotooxidációjával} \mathrm{képződik.}{ }^{113}$ Fotolízise FCO gyök képződéséhez vezet.

A termikusan instabil formil-klorid, $\mathrm{HClCO}$, a klórozott és klórozott-fluorozott szénhidrogének ózonos vagy $\mathrm{OH}$-gyökös oxidációjában megjelenő átmeneti termék, melynek jelenléte a légkör felsőbb rétegeiben a legvalószínúbb. ${ }^{114}$ Szintén jelentôs mennyiségben keletkezik klórozott metánok - elsősorban a monoklór- és diklór-metán - klóratom által inicializált gyökös mechanizmusú oxidációs folyamata során. ${ }^{115}$ Közvetlenül a $\mathrm{CH}_{2} \mathrm{ClO}+\mathrm{O}_{2} \longrightarrow \mathrm{HClCO}+\mathrm{HO}_{2}$ reakcióban képződik. Légköri reakciói közül a legfontosabbak az OH-gyökkel, a Cl-atommal és a vízgőzzel végbemenő 
folyamatok: $:^{114}$

$$
\begin{array}{r}
\mathrm{HClCO}+\mathrm{OH} \longrightarrow \mathrm{ClCO}+\mathrm{H}_{2} \mathrm{O} \\
\mathrm{HClCO}+\mathrm{Cl} \longrightarrow \mathrm{ClCO}+\mathrm{HCl} \\
\mathrm{HClCO}+\mathrm{H}_{2} \mathrm{O} \longrightarrow \mathrm{HC}(\mathrm{O}) \mathrm{OH}+\mathrm{HCl}
\end{array}
$$

A sztratoszférába kerülő különböző CFC típusú vegyületek fotooxidációja során oxi-gyökök képződnek, melyek unimolekulás bomlással halogéntartalmú karbonil vegyületekké alakulnak. A $\mathrm{CF}_{3} \mathrm{Cl}$ karbonil-difluoriddá, míg a $\mathrm{CFCl}_{3} \mathrm{CFCl}_{2} \mathrm{O}_{2}$ és $\mathrm{CFCl}_{2} \mathrm{O}$ gyökökön keresztül FClCO-vá alakul. ${ }^{116,117}$ A karbonil-klorid-fluorid fotolízissel, illetve singlet D oxigén atomokkal $\left[\mathrm{O}\left({ }^{1} \mathrm{D}\right)\right]$ és más reaktív szpécieszekkel reagálva $\mathrm{Cl}$-atomot szabadít fel, ami hozzájárul az ózonmennyiség csökkenéséhez. ${ }^{118}$

A hidrokarboxil-gyök, HOCO, a légköri szén-monoxid szén-dioxiddá alakulásának köztiterméke:119

$$
\mathrm{OH}+\mathrm{CO} \rightleftharpoons[\mathrm{HOCO}]^{\ddagger} \longrightarrow \mathrm{H}+\mathrm{CO}_{2}
$$

Az OH gyök CO-val történő ütközésekor a többletenergiával rendelkező, aktivált $[\mathrm{HOCO}]^{\ddagger}$ gyök képződik, mely háromféleképpen stabilizálódhat: i) visszaalakul reaktánsokká; ii) termékekké bomlik; vagy iii) a környezetében egy másik molekulával ütközve elveszíti többletenergiáját és HOCO gyökké alakul. A HOCO gyök a troposzférában viszonylag nagyobb mennyiségben előforduló karbonsavak közül az ecetsav légköri oxidációs folyamataiban is megjelenik mint köztitermék. ${ }^{120}$

$\mathrm{Az} \mathrm{NH}_{2} \mathrm{CO}$ gyök kevéssé tanulmányozott rendszer, szerepe és jelentősége a légkörben nem ismert.

A HS és HSO gyököknek jelentôs szerepük van az ózonréteg csökkenésében. A HS gyök a következő reakcióciklus szerint katalizálja az $\mathrm{O}_{3}$ bomlását:

$$
\begin{gathered}
\mathrm{HS}+\mathrm{O}_{3} \longrightarrow \mathrm{HSO}+\mathrm{O}_{2} \\
\mathrm{HSO}+\mathrm{O}_{3} \longrightarrow \mathrm{HS}+2 \mathrm{O}_{2}
\end{gathered}
$$

A (2.6b) reakció végterméke $\mathrm{HSO}_{2}$ és $\mathrm{O}_{2}$ is lehet, ami terminálja a katalitikus ciklust. ${ }^{121}$ Ezen kívül A HSO több más reakcióban is előfordul, melyek közül a két legfontosabb a $\mathrm{HS}+\mathrm{NO}_{2} \longrightarrow \mathrm{HSO}+$ $+\mathrm{NO}^{121}$ és a $\mathrm{O}\left({ }^{3} \mathrm{P}\right)+\mathrm{H}_{2} \mathrm{~S} \longrightarrow \mathrm{HSO}+\mathrm{H}^{122,123}$ ahol az utóbbi folyamat HOS vagy SO képződéséhez is vezethet. Az $\mathrm{SO} \mathrm{SO}_{3}$-dá történő oxidációja, majd annak kénsavvá alakulása savas esôt okoz. $^{123}$

$\mathrm{A} \mathrm{HOSO}_{2}$ gyök fontos köztiterméke a kén-dioxid katalitikus oxidációs folyamatának, melynek 
mechanizmusa: ${ }^{124,125}$

$$
\begin{array}{r}
\mathrm{OH}+\mathrm{SO}_{2}+\mathrm{M} \longrightarrow \mathrm{HOSO}_{2}+\mathrm{M} \\
\mathrm{HOSO}_{2}+\mathrm{O}_{2} \longrightarrow \mathrm{SO}_{3}+\mathrm{HO}_{2} \\
\mathrm{SO}_{3}+\mathrm{H}_{2} \mathrm{O}+\mathrm{M} \longrightarrow \mathrm{H}_{2} \mathrm{SO}_{4}+\mathrm{M}
\end{array}
$$

A (2.7a) és a (2.7c) reakciókban M jelöli az ún. „harmadik- vagy ütközési-testet”, ami egy kinetikailag harmadrendú asszociációs reakcióban felszabaduló energiatöbbletet elnyeli. ${ }^{126} \mathrm{Az} \mathrm{OH}$ gyök a $\mathrm{HO}_{2}$-ből a másodrendú $\mathrm{HO}_{2}+\mathrm{NO} \longrightarrow \mathrm{OH}+\mathrm{NO}_{2}$ folyamat szerint újratermelődik. $\mathrm{A}_{2} \mathrm{SO}_{4}$ képződése miatt a fenti reakció szintén fontos szerepet játszik a savas eső kialakulásában. Érdemes megjegyezni, hogy légköri körülmények között a (2.7a) reakció lassú, míg a (2.7b) és a (2.7c) reakciók ehhez képest sokkal gyorsabbak, így a $\mathrm{SO}_{2}$ hosszú, míg a $\mathrm{HOSO}_{2}$ gyök és a $\mathrm{SO}_{3}$ molekula rövid élettartammal rendelkezik.

A metil-merkaptánból származtatható $\mathrm{CH}_{2} \mathrm{SH}$ gyök legfontosabb légköri folyamatai a gyök $\mathrm{O}_{2}$-nel, $\mathrm{NO}_{x}$ gázokkal és ózonnal történő reakciói. $\mathrm{A} \mathrm{CH}_{2} \mathrm{SH}+\mathrm{O}_{2} \longrightarrow \mathrm{CH}_{2} \mathrm{~S}+\mathrm{HO}_{2}$ reakcióban $\mathrm{HO}_{2}$ gyök képződik, ${ }^{127}$ mely az ózonkémia egyik legfontosabb és leggyakrabban előforduló köztiterméke. $\mathrm{A} \mathrm{CH}_{2} \mathrm{SH}$ gyök reakciói $\mathrm{NO}_{x}$ gázokkal szintén fontos folyamatok olyan területeken, ahol $\mathrm{NO}_{x}$ koncentráció számottevő. A kérdéses reakciók közül a leginkább kedvezményezett a szénatomra történő addíció, valamint az absztrakciós csatorna, melyek során rendre HNO és HONO gyökök keletkeznek. ${ }^{127}$

A szulfinok legegyszerúbb képviselője, a $\mathrm{CH}_{2} \mathrm{SO}$, a metil-merkaptán légköri oxidációs folyamatának egyik fontos köztiterméke. ${ }^{128}$ Szintén előfordul a $\mathrm{CH}_{3} \mathrm{SO}$ ózonnal történő reakciójában: ${ }^{129}$

$$
\mathrm{CH}_{3} \mathrm{SO}+\mathrm{O}_{3} \longrightarrow \mathrm{CH}_{2} \mathrm{SO}+\mathrm{OH}+\mathrm{O}_{2}
$$

A $\mathrm{CS}_{2} \mathrm{OH}$ összegképletú gyök a szén-diszulfid légköri oxidációjának köztiterméke. A kérdéses oxidációs folyamat a következő mechanizmussal írható le:

$$
\begin{array}{r}
\mathrm{CS}_{2}+\mathrm{OH}+\mathrm{M} \rightleftharpoons \mathrm{CS}_{2} \mathrm{OH}+\mathrm{M} \\
\mathrm{CS}_{2} \mathrm{OH}+\mathrm{O}_{2} \longrightarrow \text { termékek }
\end{array}
$$

ahol M az „ütközési testet” jelöli. A (2.9b) reakció legvalószínúbb termékei az OCS és SH gyökök, valamint a $\mathrm{SO}_{2}$ és $\mathrm{CO}$ molekulák. Érdemes megjegyezni, hogy a reakció rendkívül összetett, több mint 25 exoterm reakciócsatorna létezik. ${ }^{130,131}$ A (2.9a) folyamatban az OH gyök mind a szén-, mind a kénatomhoz kapcsolódhat, így nyilvánvalóan a $\mathrm{CS}_{2} \mathrm{OH}$ kétféle szerkezeti izomerrel rendelkezik: a C-izomer $\mathrm{S}_{2} \mathrm{COH}$ és az S-izomer SCSOH képződése is lehetséges. Az 5.7.3 fejezetben a kérdéses reakciót részletesen is tárgyalni fogom. 


\section{Célkitúzés}

Doktori munkám elsődleges célja a 2.1. táblázatban szereplő gyökök és molekulák pontos standard képződési entalpiáinak és entrópiáinak, valamint hőmérsékleti korrekcióinak elméleti úton történő meghatározása, melyekhez jól definiált hibahatár is tartozik. Ez több lépcsőben, két új, többékevésbé rendszerspecifikus ab initio termokémiai modell kidolgozásával lehetséges.

A kiindulási alap a formaldehid molekula eredeti, módosítások nélküli HEAT protokollal számított képződési entalpiája volt. A modellben figyelembe vett hozzájárulások magasabb elméleti szintekre emelésével, valamint újabb korrekciók bevonásával egy olyan FPA alapú modellt szeretnénk kidolgozni, ami minden eddiginél pontosabb - beleértve az ellentmondásos kísérleti adatokat is - és a későbbi termokémiai alkalmazásokban teljes biztonsággal felhasználható képződési entalpia adatot szolgáltat a molekulára.

Második lépcsőben a formaldehid hidrogénjeinek eliminációjával és/vagy szubsztitúciójával előállítható gyökök és molekulák termokémiai paramétereit szeretnénk számítani költséghatékony módon. Ehhez kézenfekvő választás egy csekély mértékben módosított HEATII modell, amivel belátható futási időn belül pontos eredmények várhatók. A cél, hogy a számított adatok alapján a rendelkezésre álló irodalmi referenciaadatok közötti diszkrepanciát feloldjuk, valamint a pontatlan mérésekből és számításokból származó értékek helyett kisebb bizonytalansággal rendelkező pontosabb paramétereket közöljünk.

Harmadik lépcsőben a kísérletileg és elméletileg is nehezen kezelhető, kénatomot tartalmazó légkörkémiai fontosságú kisebb vegyületek kezelését tûztük ki célul, melyek termodinamikai referenciaadatai szintén megkérdőjelezhetô pontosságúak. A kénatom jelenléte miatt ehhez egy új termokémiai modell kidolgozása, annak tesztszámításokkal történő ellenőrzése, és ez utóbbiból az adatokhoz tartozó bizonytalanságok becslése szükséges. A kidolgozásnál figyelembe kell venni, hogy teljesüljön a protokoll „fekete doboz” jellege, azaz általánosan felhasználható legyen hasonló kémiai rendszerek esetén. 


\section{Elméleti összefoglaló}

\subsection{Modellek}

\subsubsection{A focal-point modell}

A focal-point filozófia alapvetően különbözik a többi elméleti kémiai modelltől. Utóbbiak, ahogyan a 4.1.2. és a 4.1.3. fejezetekben látni fogjuk, egy jól definiált, ésszerúen kidolgozott lépéssorozat (algoritmus) szerint állítják elő a vizsgált rendszer teljes energiáját. További lényeges különbség, hogy az FPA modell szigorú értelemben véve nem egy protokolláris módon felírt összegzésen alapul, de az egyes hozzájárulásokat itt is additívnek tekintjük. A különböző elméleti szinteken, szisztematikusan növekedő bázisokkal végzett számítási eredményekből táblázatot készítünk. A tulajdonképpeni protokoll a táblázat kiértékelésekor áll össze. A doktori dolgozatomban alkalmazott FPA modell esetén az analízis tulajdonképpen a nemrelativisztikus hozzájárulásokra vonatkozik, az egyéb korrekciókat jól definiált, rögzített elméleti szinten közelíti. Azaz a szisztematikusan növekedô bázisokkal számított HF-SCF, CCSD, CCSD(T), CCSDT, CCSDT(Q), CCSDTQ, valamint CCSDTQ(P) tagokból összeállított táblázatot készítjük el, és minden esetben a legmagasabb szintû eredményt fogadjuk el a kérdéses hozzájárulás végső értékének.

A formaldehid, $\mathrm{H}_{2} \mathrm{CO}$, kicsiny mérete - két nehéz (nemhidrogén) és két könnyú (hidrogén) atomból álló rendszer -, zárt elektronszerkezete és viszonylag magas szimmetriája $\left(\mathrm{C}_{2 \mathrm{v}}\right)$ komoly számítási szintek alkalmazását teszi lehetővé. Éppen ezért termokémiai paramétereinek elméleti meghatározásához a focal-point módszer a legmegfelelőbb választás, mivel a „fekete doboz" módszerek többnyire kötött, receptszerú metódusa helyett egy olyan önkényesen tervezett lépéssorozatból álló protokollt építhetünk fel, amelyben a figyelembe veendő hozzájárulásokat a kitúzött pontosság eléréséhez szükséges mértékben konvergáltathatjuk.

A formaldehid FPA modelljében a számítások alapjául a CCSD(T)/aug-cc-pCVQZ szinten meghatározott egyensúlyi geometria szolgált, ahol a törzs- és vegyértékelektronok korrelációs hatásait az FC közelítéssel ellentétben együttesen kezeltük (AE-CCSD(T), all-electron).

Az elektronszerkezeti számításokban a Dunning-féle korreláció-konzisztens aug-cc-pVXZ és aug-cc-pCVXZ ( $X=\mathrm{D}(2), \mathrm{T}(3), \mathrm{Q}(4), 5,6)$ báziskészleteket ${ }^{132-135}$ használtuk, melyek szisztematikusan közelítik a végtelen, csonkítás nélküli bázist, lehetővé téve ezáltal extrapolációs összefüggések használatát a határenergiák becsléséhez. 
A referencia-hullámfüggvény zárt héjú esetben RHF (megszorításos Hartree-Fock), nyílt héjú esetben (atomok) pedig UHF (megszorítás nélküli HF) pályákból állt elô. Az ROHF (megszorításos nyílt héjú HF) referencia használata kizárólag a HF hozzájárulás értékét befolyásolja, korrelációs szinten azonban az UHF-en alapuló számításokéval közel azonos eredményt szolgáltat.

Az elektronkorrelációs hozzájárulások számítása a tradicionális CC módszerekkel ${ }^{136}$ történt, ahol iteratív egy- és kétszeres (CCSD), ${ }^{137}$ háromszoros, $\mathrm{CCSDT}^{138,139}$ és négyszeres, CCSDTQ, valamint perturbatív háromszoros, $\operatorname{CCSD}(\mathrm{T}),{ }^{140}$ négyszeres, $\operatorname{CCSDT}(\mathrm{Q}){ }^{141}$ és ötszörös, $\operatorname{CCSDTQ}(\mathrm{P})^{142}$ gerjesztési szinteket vettem figyelembe. A legnagyobb számítási igényú CCSDTQ(P) energiatagot az FC közelítésen belül, az aug-cc-pVDZ bázissal határoztam meg, feltételezve egyrészt azt, hogy ezen a magas elméleti szinten számított járulék már ezzel a kis bázissal is eléri a kívánt konvergenciát, másrészt azt, hogy a négyszeres gerjesztések feletti korrelációs hozzájárulások jó közelítéssel csak a vegyértékelektronok kölcsönhatásaiból származnak.

Az aug-cc-pCVXZ bázisokkal számított elektronenergiákból extrapolációs formulák alkalmazásával közelítettük a végtelen bázishoz tartozó határértékeket. A HF energiákat a következő kétparaméteres formula ${ }^{143-145}$ szerint állítottuk elő:

$$
E_{\mathrm{HF}}^{X}=E_{\mathrm{HF}}^{\infty}+a(X+1) e^{-9 \sqrt{X}},
$$

ahol $X$ a kérdéses báziskészlet kardinális száma, $E_{\mathrm{HF}}^{X}$ az ezzel a bázissal számított HF energia és $E_{\mathrm{HF}}^{\infty}$ a HF végsố energia. A korrelációs hozzájárulásokat a Helgaker és csoportja által javasolt ${ }^{146}$ kétpontos köbös formula szerint extrapoláltuk:

$$
\Delta E_{\mathrm{CC}}^{X}=\Delta E_{\mathrm{CC}}^{\infty}+b \cdot X^{-3}
$$

ahol $\Delta E_{\mathrm{CC}}^{X}$ az $X$ kardinális számú bázisfüggvénnyel számított $\mathrm{CC}$ szintú elektronikus energiát, $\Delta E_{\mathrm{CC}}^{\infty}$ a CC határenergiát és $b$ az extrapolációs paramétert jelöli.

A CCSD(T) korrelációs hozzájárulások konvergenciavizsgálata érdekében F12 explicite korrelált számításokat végeztünk, ahol az alkalmazott korrelációs faktor $\exp \left(-\gamma \cdot r_{12}\right)$ volt, ${ }^{147}$ ahol $r_{12}$ jelöli az elektronok távolságát, a $\gamma$ konstans értékét pedig pontosan 1.0-nak választottuk, ami a másodrendú F12 elméletbôl következik. A számításokhoz az aug-cc-pCV(5 és 6)Z bázisokat használtuk, melyek alkalmazhatóságát olyan tesztszámításokkal igazoltuk, melyeket az explicite korrelált módszerekhez kidolgozott, kontrakció nélküli R12-bázisokkal végeztünk. Hidrogénatomok R12-készlete a $(9 s 6 p 4 d 3 f)^{148}$ séma szerint jelölhető, míg nemhidrogén atomokra a $(19 s 14 p 8 d 6 f 4 g 3 h)^{149}$ érvényes.

A relativisztikus hatások hozzájárulását kétféle közelítés szerint számítottuk. Az elsôrendű perturbációs elméletből adódó skaláris relativisztikus korrekciókat (tömeg-sebesség és egyelektron Darwin-tag, MVD1) átlagoltuk a Douglas-Kroll-Hess ${ }^{150,151}$ (DKH) elmélettel kapott eredményekkel. A relativisztikus számításokat AE-CCSD(T)/aug-cc-pCVTZ szinten végeztük.

A hagyományos elektronszerkezeti számítások eredményeként kapott energia nem ekvivalens 
annak a Hamilton-operátornak a várható értékével, melyet - a Born-Oppenheimer (BO) közelítés szerint - rögzített magkoordináták mellett a molekula elektronjainak hullámfüggvényeiből állítunk elő. Pontos képet akkor kapunk, ha figyelembe vesszük a magmozgás kinetikus energia operátorának hozzájárulását a teljes elektronikus energiához. Ez a DBOC, melyet a magok kinetikus energia operátorának $\left(\hat{T}_{n}\right)$ elektronhullámfüggvény $\left[\Psi_{e}(\mathbf{r} ; \mathbf{R})\right]$ szerinti várható értékéből számítunk: $:^{152-156}$ :

$$
\Delta E_{\mathrm{DBOC}}=\left\langle\Psi_{e}(\mathbf{r} ; \mathbf{R})\left|\hat{T}_{n}\right| \Psi_{e}(\mathbf{r} ; \mathbf{R})\right\rangle
$$

A hozzájárulás számítása az FPA modellben HF-SCF/aug-cc-pVTZ szinten történt, melyet FCCISD/ aug-cc-pVTZ korrelációs járulékkal egészítettünk ki.

A zéruspont rezgési energiát (ZPE) harmonikus és anharmonikus rezgési számítások összegéből állítottuk elő. A harmonikus rezgési frekvenciákat $\left(\omega_{i}\right.$, ahol $i$ jelöli a rezgési normálmódusokat) az ACESII-MAB programban ${ }^{157}$ rendelkezésre álló analitikus második deriváltakkal ${ }^{158,159}$ számítottuk CCSD(T)/aug-cc-pCVTZ szinten. Ezekből a harmonikus ZPE hozzájárulása a teljes energiához a következő összefüggés szerint adható meg:

$$
\Delta E_{\mathrm{ZPE}}=\sum_{i} \frac{\omega_{i}}{2}
$$

A ZPE anharmonikus korrekcióit variációs magmozgás számítások eredményeiből kaptuk, melyeket a molekula globális potenciális energiafelületének (PES) felhasználásával állítottunk elő. A ZPE anharmonikus korrekcióját a variációsan számított anharmonikus és harmonikus ZPE-k különbsége szerint definiáljuk, melyeket ugyanazon a PES-en számítunk. Az így kapott anharmonikus korrekció bizonytalansága feltehetôen jelentősen kisebb, mint a külön-külön számított individuális anharmonikus és harmonikus zérusponti energiáké. A globális PES FC-CCSD(T)/aug-ccpVTZ szinten számított ab initio adatokhoz történő illesztésből származik. A jelen munka tárgya elsôsorban a molekula egyensúlyi geometriájára, illetve annak közvetlen környezetére korlátozódik, de az illesztés során ettôl eltávolodva több fragmentációs csatornára számított ab initio eredményt is figyelembe vettünk az illesztésnél. Az eljárás a súlyozott legkisebb négyzetek módszere szerint történt, ahol a súlyfaktor

$$
w=\frac{E_{0}}{E+E_{0}}
$$

volt, ahol $E$ a globális minimumhoz képest számított relatív energia. Az $E_{0}$ paraméter értékének a relatíve kicsi $0.02 E_{\mathrm{h}}$-t választottuk, ami megfelelő az egyensúlyi geometria környezetében végzett számítások esetén. Az illesztéshez használt célfüggvény egy hatodfokú polinom volt, mely Morsetípusú változóként az atomi távolságokat tartalmazta és a hidrogének permutációjára invariáns volt. Az szabad illesztési paraméterek összes száma 1601 volt.

A képződési entalpia számításához szükséges $\mathrm{H}_{2}$ és $\mathrm{CO}$ molekulák ZPE értékei irodalomból 
származó nagy pontosságú variációs számítások eredményei voltak. A $\mathrm{H}_{2}$ molekula ZPE-je 26.07 $\mathrm{kJ} \mathrm{mol}^{-1},{ }^{160}$ míg a CO-é $12.94 \mathrm{~kJ} \mathrm{~mol}^{-1}{ }^{161}$

Amennyiben a képződési entalpia számításához a $\mathrm{H}_{2} \mathrm{O}+\mathrm{C}=\mathrm{H}_{2} \mathrm{CO}$ reakciót választjuk alapul, szükségünk van a $\mathrm{H}_{2} \mathrm{O} Z \mathrm{ZPE}$-jére is. Ez szintén egy irodalomból származó, extrém nagy pontosságú variációs módszerrel számított érték, $55.49 \pm 0.02 \mathrm{~kJ} \mathrm{~mol}^{-1}$. ${ }^{162,163}$

A formaldehid képződési entalpiája mellett a molekula protonaffinitását (PA) is meghatároztuk a fentiekben definiált FPA modell szerint a $\mathrm{H}_{2} \mathrm{COH}^{+}$ionra végzett számításokon keresztül. Doktori munkám során csak a képződési entalpia számításával foglalkoztam, így a PA-ra vonatkozó eredmények itt nem kerülnek felhasználásra és bemutatásra.

Az explicite korrelált F12-CCSD(T) számításokat Ján Šimunek és Jozef Noga végezte (Comenius University, Slovakia). A variációs magmozgásszámításokból származó anharmonikus korrekciókat Czakó Gábor és Császár Attila (ELTE, Molekulaspektroszkópia csoport) határozta meg, együttmúködve Bastiaan J. Braams-szal és Joel M. Bowman-nel (Emory University, Atlanta, USA). A fenti eredményeket felhasználom és bemutatom, de nem tekintem óket sajátjaimnak.

\subsubsection{A HEAT-345(Q) modell}

A formaldehid származékok képződési entalpiáját $\left(\Delta_{f} H_{0}^{\circ}\right.$ és $\left.\Delta_{f} H_{298}^{\circ}\right)$, hőmérsékleti korrekcióját $\left(H_{298}^{\circ}-H_{0}^{\circ}\right)$ és standard moláris entrópiáját $\left(S_{298}^{\circ}\right)$ egy csekély mértékben módosított HEAT$345(\mathrm{Q})^{52}$ termokémiai modellel számítottam. A modell lényegében a csatolt-klaszter ${ }^{136}$ elméleten alapul és a Dunning-féle korreláció-konzisztens bázisfüggvényeket használja, melyek lehetővé teszik az egyes bázisokkal számított eredményekből történő extrapolációt. A termokémiai paraméterek előállításához szükséges megfelelő pontosságot további korrekciók figyelembevételével érhetjük el. A számítások referencia-hullámfüggvényei zárt héjú molekuláknál RHF, nyílt héjú gyököknél és a szénatomnál pedig UHF pályák voltak. A CCSDT és CCSDT(Q) számítások kivételével mindenütt explicite figyelembe vettük a törzs- és vegyértékelektronok korrelációját, míg az előbbi két módszernél az FC közelítést alkalmaztuk.

Az összes számításban CCSD(T)/cc-pVQZ szinten meghatározott egyensúlyi geometriákat használtunk fel. Több tanulmány, köztük a HEAT projektek is alátámasztják, ${ }^{51-53,164}$ hogy az ezen az elméleti szinten számított struktúrák pontossága elegendô a termokémiai adatok pontos becsléséhez, melyet a jelen munka is megerősít.

Kompozit modellünkben a teljes energiát, $E_{\mathrm{TOT}}$, az alábbi hozzájárulásokat tartalmazó összeg szerint definiáltuk:

$$
E_{\mathrm{TOT}}=E_{\mathrm{HF}}^{\infty}+\Delta E_{\mathrm{CCSD}(\mathrm{T})}^{\infty}+\Delta E_{\mathrm{CCSDT}}^{\infty}+\Delta E_{\mathrm{CCSDT}(\mathrm{Q})}+\Delta E_{\mathrm{ZPE}}+\Delta E_{\mathrm{DBOC}}+\Delta E_{\mathrm{REL}}
$$

Az egyenletben $E_{\mathrm{HF}}^{\infty}$ a HF-SCF energiát jelenti végtelen bázisra extrapolálva, melyet az aug-ccpCV(T,Q,5)Z számításokból a 4.7 egyenlet szerinti Feller-féle hárompontos extrapolációs formu- 
la ${ }^{165}$ alapján határoztunk meg:

$$
E_{\mathrm{HF}}^{X}=E_{\mathrm{HF}}^{\infty}+b \cdot e^{-c X},
$$

ahol $E_{\mathrm{HF}}^{X}$ a 3(T), 4(Q), 5 kardinális számú bázisokkal számított HF-SCF energia, $E_{\mathrm{HF}}^{\infty}$ a HF-SCF végső energia, $b$ és $c$ pedig extrapolációs paraméterek. ${ }^{*}$ A hozzájárulás konvergenciájának vizsgálata céljából a HF-SCF energiát az aug-cc-pCV6Z bázissal is kiszámítottam, és a 4.7, valamint a 4.1 összefüggések szerint elvégeztem a $(Q, 5,6)$ és $(5,6)$ alapú extrapolációt is. Az így kapott $E_{\mathrm{HF}}^{\infty}$ tagokat $E_{\mathrm{TOT}}$ kifejezésébe helyettesítve szintén meghatároztam a $\Delta_{f} H_{0}^{\circ}$ eredményeket. Ugyan az eredeti protokoll a 4.7 összefüggés szerint, az aug-cc-pCV(T,Q,5)Z eredményekből extrapolált HF-SCF járulékok használatát írja elő, a végeredmények számításához - az értékek nyilvánvalóan jobb konvergenciája miatt - mégis a 4.1 egyenlet szerint számított $(5,6)$ extrapolációval elóállított $E_{\mathrm{HF}}^{\infty}$ energiákat fogadtam el.

A 4.6 összeg második tagja, $\Delta E_{\mathrm{CCSD}(\mathrm{T})}^{\infty}$, a korrelációs energia a perturbatív háromszoros gerjesztési szintú csatolt-klaszter módszerrel számítva. A hozzájárulás extrapolációja az aug-ccpCV(Q és 5)Z bázisok eredményeiből a Helgaker-féle kétpontos formula (4.2 egyenlet) szerint történt.

A 4.6 egyenlet harmadik és negyedik tagja $-\Delta E_{\mathrm{CCSDT}}^{\infty}$ és $\Delta E_{\mathrm{CCSDT}(\mathrm{Q})}$ - a magasabb rendû korrelációs hatások hozzájárulását szolgáltatja a teljes energiához. Ezek közül az elsôt az $E_{\mathrm{CCSDT}}-E_{\mathrm{CCSD}(\mathrm{T})}$ energiakülönbség szerint definiáltuk, melyet a 4.2 formulával extrapolálunk a cc-pVTZ és a cc-pVQZ bázisokkal kapott értékekből. A másodikat, a CCSDT(Q) energiatagot, az $E_{\mathrm{CCSDT}(\mathrm{Q})}-E_{\mathrm{CCSDT}}$ különbség szerint számítjuk a cc-pVDZ bázissal. Mindkét esetben alkalmazzuk az FC-közelítést. Az Irodalmi áttekintésben említést tettünk a kis bázisokkal számított CCSDT(Q) hozzájárulás nem megfelelő konvergenciájáról. Martin és csoportja szerint ${ }^{55}$ ez főleg a fluort és második periódusbeli atomokat tartalmazó rendszerek termokémiai számításaiban játszik fontos szerepet. Az ilyen molekulák esetén a kérdéses (Q) tagok meghatározásához legalább háromszoros- $\zeta$ minőségú bázisokat javasolnak. Ezért az összes itt tárgyalt formaldehid származékra elvégeztük a kérdéses CCSDT(Q)/cc-pVTZ számításokat. A legnagyobb eltérések a cc-pVDZ és cc-pVTZ bázisokkal számított eredmények között valóban a F- és Cl-atomokat tartalmazó rendszereknél tapasztalhatók, összhangban Martin és munkatársai által közöltekkel. A végeredmények számításához a cc-pVDZ-vel kapott eredményeket használtam fel, a cc-pVTZ adatok összehasonlítási célt szolgálnak.

Érdemes itt megjegyezni, hogy az eredeti, teljes HEAT protokollban a legmagasabb szintú korrelációs hozzájárulás iteratív négyszeres gerjesztési szintû FC-CCSDTQ/cc-pVDZ számításból származik, amiből a modell szisztematikus elnevezése HEAT-345Q. A HEAT-345(Q) modell viszont a perturbatív négyszeres gerjesztési szintű CCSDT(Q) módszert ${ }^{141}$ alkalmazza. Kidolgozása

\footnotetext{
*A továbbiakban a(z) (aug-)cc-p(C)V(I,J,K)Z kardinális számú bázisokon alapuló extrapolációt $(I, J, K)$ szerint jelölöm.
} 
és tesztelése során észrevették, ${ }^{52}$ hogy a HEAT-345(Q)-val kapott eredmények, az eredeti modellhez képest, jobban egyeznek az iteratív ötszörös gerjesztési szintú, CCSDTQP tagot is tartalmazó HEAT-345QP-vel számítottakkal. Ennek legvalószínúbb oka, hogy hasonlóan a CCSD(T) és CCSDT kezeléshez, a CCSDT(Q) módszer is túlbecsüli a korrelációs energiát az iteratív CCSDTQ megfelelőhöz képest. Mindazonáltal a HEAT-345(Q) tesztkészletében nem volt olyan molekula, melynek számított képződési entalpiája $0.75 \mathrm{~kJ} \mathrm{~mol}^{-1}$-nél többel tért volna el a kísérleti adattól. Mindezek tekintetében, figyelembe véve a számítási kapacitást és gépidőt is, a magasabb rendú korrelációs hatásokat a CCSDT(Q) modell szerint határoztam meg, az ennél magasabb gerjesztési szintekkel nem foglalkoztam.

A zéruspont-rezgési energia, $\Delta E_{\mathrm{ZPE}}$ a 4.6 egyenletben, a HF-SCF és CCSD(T) tagok után a teljes energia legnagyobb hozzájárulását szolgáltatja. Értékét a 4.8 egyenlet szerint számítjuk a VPT2 (second-order vibrational perturbation theory) elmélet szerint: ${ }^{166}$

$$
\Delta E_{\mathrm{ZPE}}=G_{0}+\sum_{i} \frac{\omega_{i}}{2}+\sum_{i \geq j} \frac{x_{i j}}{4}
$$

ahol a második tag a jól ismert harmonikus közelítés, és az egyes $\omega_{i}$-k az $i$-edik rezgési normálmódushoz tartozó harmonikus freqvenciák. A 4.8 egyenlet elsố és harmadik tagja a zéruspont-rezgési energia anharmonikus hozzájárulását adja, ahol az $x_{i j}$-k az anharmonicitási konstansok. Az első tag, $G_{0}$, a rezgési állapottól független konstans, melynek hozzájárulása a zérusponti energiához általában kisebb, mint $10 \mathrm{~cm}^{-1}\left(0.12 \mathrm{~kJ} \mathrm{~mol}^{-1}\right) .{ }^{51}$ Mind a harmonikus, mind az anharmonikus számítások CCSD(T)/cc-pVQZ elméleti szinten történtek. A harmonikus frekvenciák számításához az analitikus második deriváltakat ${ }^{158,159}$ használtuk, míg az anharmonicitási konstansok az analitikus második deriváltak numerikus differenciálásából előálló köbös erôterekből származnak. 52, 167 A késôbbiekben látni fogjuk, hogy az anharmonikus hozzájárulások figyelembevétele csak az extrém nagy pontosságú számításokban szükséges, ellenkező esetben legtöbbször elhanyagolhatók.

A teljes energiát definiáló 4.6 egyenlet következő tagja, $\Delta E_{\mathrm{DBOC}}$, a diagonális Born-Oppenheimer korrekció. Modellünkben a hozzájárulást a Gauss-féle formalizmus ${ }^{156}$ szerint CCSD/augcc-pCVTZ elméleti szinten számítjuk. Érdemes megjegyezni, hogy a HEAT protokollok mindegyike, valamint első közelítésben az FPA is, HF-SCF szintet használ a DBOC meghatározására. Ez a hozzájárulás az összes közül a legkisebb mértékú és sok esetben elhanyagolható, amennyiben a kívánt pontosság $\pm 1 \mathrm{~kJ} \mathrm{~mol}^{-1}$-nél nagyobb. Az ennél nagyobb pontosságot célzó elméleti modellekből azonban semmiképpen sem hiányozhat.

A 4.6 egyenlet utolsó tagja, $\Delta E_{\mathrm{REL}}$, a skaláris relativisztikus hatások járuléka a teljes energiához. Ezt a tömeg-sebesség, valamint az egy- és kételektronos Darwin-operátor (MVD2) várható értékéből számítjuk a CCSD(T)/aug-cc-pCVTZ szinten. Atomok esetén a hozzájárulás tartalmazza a spin-pálya csatolás (SPO) mértékét is. Ennek számítását a szénatom példáján a 4.1 ábra mutatja be. A korrekció számítása a többi atom esetén hasonlóan történt. Az atomi nívók energiáinak kísérleti értékei az NIST Atomic Spectra Database ${ }^{168}$-ből származnak. 


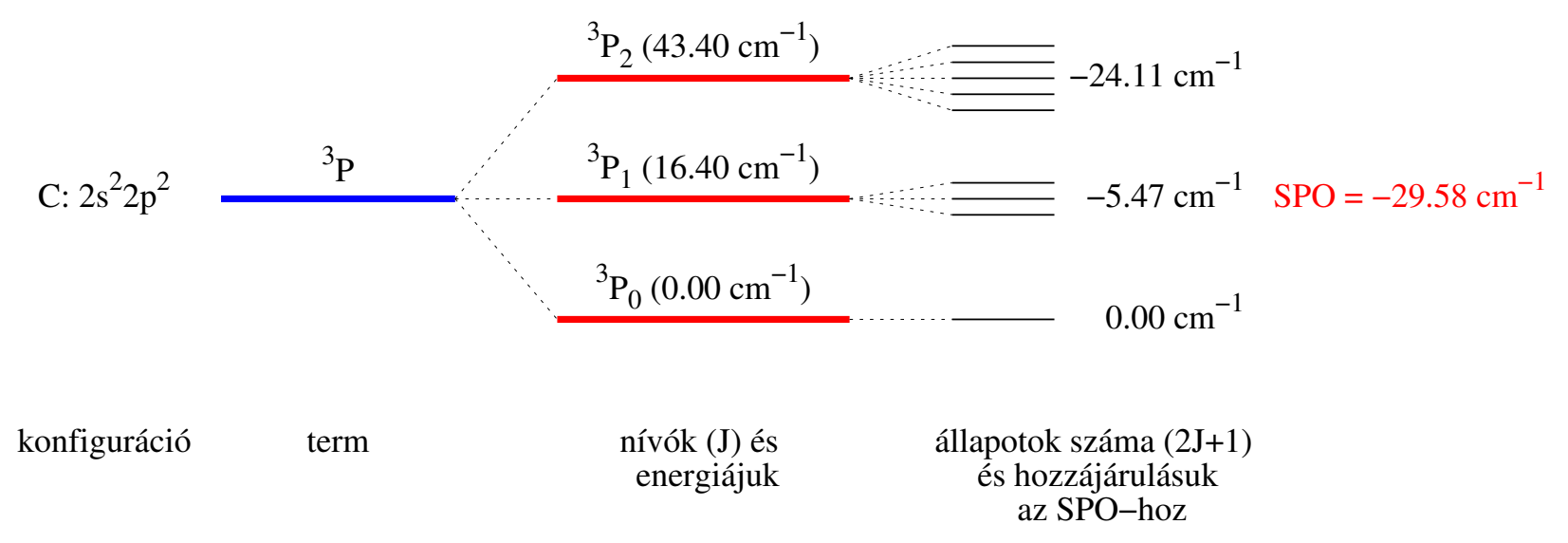

4.1. ábra

A szénatom spin-pálya csatolásának számítási sémája

A 4.6 teljes energiából, a CCSD(T)/cc-pVQZ harmonikus frekvenciákból, valamint a forgási állandókból a statisztikus termodinamika összefüggései szerint, ${ }^{169} T=0$ és $298.15 \mathrm{~K}$ hőmérsékleten valamint $p=1.0$ bar (100 kPa) nyomáson számítottam a standard képződési entalpiákat és entrópiákat a merev rotátor-harmonikus oszcillátor (RRHO, rigid rotor-harmonic oscillator) közelítésen belül. A számítások további részleteivel a 4.2. fejezet foglalkozik.

\subsubsection{A HEAT-345 $+d(Q)$ modell}

További bonyodalmat okoz a kénatom megjelenése a kémiai rendszerekben. A szakirodalom régóta foglalkozik a második periódusbeli atomokra, illetve az ezeket tartalmazó molekulákra és gyökökre végzett számítások konvergencia-problémáival. 1995-ben Bauschlicher és Partridge az $\mathrm{SO}_{2}$ molekula atomizációs energiájának elméleti meghatározásakor szokatlanul nagy eltérést tapasztalt a számított és az irodalmi kísérleti adatok között ${ }^{170}$; az eltérés $\sim 25 \mathrm{~kJ} \mathrm{~mol}^{-1}$ volt. Eredményeik szerint az aug-cc-pVTZ bázis jelentősen gyengébben teljesített, mint a Pople-féle 6-311+G(3df,2p) bázis. Ezt a nagy exponensú, azaz az atommaghoz szorosan kötött $d$-típusú függvények, az ún. szoros- $d$ függvények (tight-d functions, 4.2 ábra) hiányával magyarázták a Dunning-féle báziskészletekben, és elsôként tettek javaslatot ilyen kiegészítésre kéntartalmú molekulák atomizációs és disszociációs energiáinak számítása esetén. A későbbiekben több más csoport ${ }^{171-175}$ is javasolta a tight-d függvényekkel kiegészített (aug-)cc-pVXZ bázisok használatát kén- és más, második periódusbeli atomokat tartalmazó szpécieszek esetén. Az új készletekre a(z) (aug-)cc-pV( $X+d) Z^{176}$ jelölést vezették be. Az itt kidolgozott HEAT-345+d(Q) modellben †, ahol az szükséges volt, a szoros- $d$ függvényekkel kiegészített báziskészleteket alkalmaztuk. Érdemes itt megjegyezni, hogy

\footnotetext{
†A modell elnevezése önkényes, de követi az 52 referenciában bevezetett egységes formát. A "345, utal a HF-SCF és CCSD(T) extrapolált járulékok számításához használt bázisokra, a ” $+d$, jelöli a szoros- $d$ függvényekkel történő kiegészítést, míg a ”(Q),, a magasabb rendű CC számítások esetén a CCSDT(Q) módszer használatát jelenti.
} 


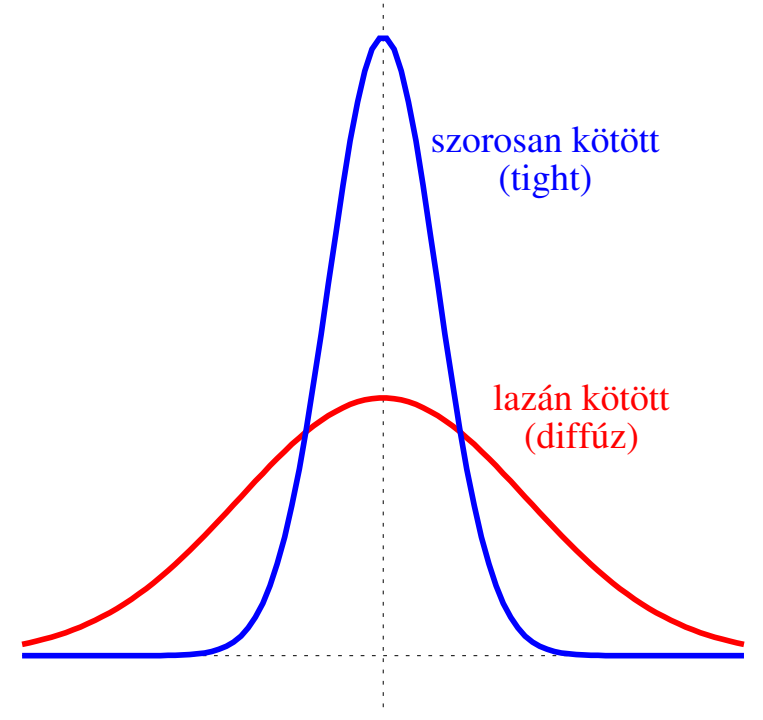

4.2. ábra

A nagy exponensû szorosan (tight) és a kis exponensû lazán kötött (diffúz) Gauss-típusú bázisfüggvények alakja

a törzselektronok korrelációs tulajdonságait explicite kezelő (aug-)cc-pCVXZ készletek nem szorulnak a fentiek szerinti kiegészítésre. Ennek egyszerú oka az, hogy a kérdéses bázisok a priori több $d$-típusú függvényt tartalmaznak, mint a vegyérték-korrelációs megfelelőik, így önmagukban is biztosítják a megfelelő konvergenciát.

A HEAT-345+d(Q) modell kidolgozása, valamint pontosságának ellenőrzése során, összesen négy protokoll teljesítőképességét vizsgáltuk néhány olyan kisebb molekulára, melyek irodalmi képződési entalpiái és entrópiái nagy pontossággal rendelkezésünkre álltak. Ezek a molekulák az $\mathrm{S}_{2}, \mathrm{H}_{2} \mathrm{~S}$, SO és $\mathrm{SO}_{2}$ voltak, míg a modellek pontosság szerinti növekvő sorrendben az alábbiak szerint definiálhatók:

1. modell: Az első tesztmodell a Csontos és munkatársai által fluorozott és klórozott szénhidrogénekre alkalmazott, ${ }^{177}$ a HEAT-345(Q)-ból egyszerúsítésekkel levezetett protokoll volt. A dolgozatomban bemutatott HEAT-345+d(Q)-tôl lényegében annyiban tér el, hogy nem használ szoros- $d$ függvénnyel kiegészített báziskészleteket.

2. modell: A második tesztmodell a végső, a dolgozatomban vizsgált kéntartalmú származékok vizsgálatához kidolgozott protokoll volt, melyet az alábbiakban részletesen bemutatok.

3. modell: A harmadik modell a másodikkal ekvivalens, de figyelembe veszi a szoros- $d$ függvények hatását a geometriai optimalizálásra és ebből következően a harmonikus és anharmonikus frekvenciaanalízis eredményére. Azaz a kérdéses számítások rendre AE$\operatorname{CCSD}(\mathrm{T}) / \mathrm{cc}-\mathrm{pV}(\mathrm{Q}+d) \mathrm{Z}, \mathrm{AE}-\mathrm{CCSD}(\mathrm{T}) / \mathrm{cc}-\mathrm{pV}(\mathrm{Q}+d) \mathrm{Z}$ és $\mathrm{AE}-\mathrm{CCSD}(\mathrm{T}) / \mathrm{cc}-\mathrm{pV}(\mathrm{T}+d) \mathrm{Z}$ szinten történtek. 
4. modell: A negyedik modell teljes egészében a formaldehid származékaira alkalmazott HEAT345(Q) protokoll volt, mindenféle módosítás nélkül.

Az alábbiakban a 2. modell részletes bemutatása következik, melyből az 1. és 3. modellek nyilvánvalóan következnek. A 4. modell részletes bemutatásával az előző fejezet foglalkozik.

A számításokat a molekulák és gyökök konformációs analíziseivel kezdtük. A konformerek és a rotációs gátak meghatározása megszorításos optimalizálással történt CCSD(T)/cc-pVTZ szinten. A konformációs teret szisztematikus módon vettük fel: a tanulmányozott szpéciesz torziós szögét 15 fokonként növeltük, majd ezt fixen tartva az összes többi geometriai paramétert optimalizáltuk. A konformációs analízissel előálló lokális minimumokhoz tartozó egyensúlyi szerkezeteket CCSD(T)/cc-pVQZ szinten mindenféle megszorítás nélkül újraoptimalizáltuk. A konformációs analízisek eredményeiből az RRHO közelítés hibáját javítottuk azon molekulákra, melyek gátolt rotációkat tartalmaztak. A 4.2. fejezetben bemutatott modell szerint korrigáltuk a zérusponti energiákat, standard moláris entrópiákat és termikus korrekciókat.

A rendszer teljes energiáját a következő összeg szerint definiáltuk:

$$
E_{\mathrm{TOT}}=E_{\mathrm{HF}}^{\infty}+\Delta E_{\mathrm{CCSD}(\mathrm{T})}^{\infty}+\Delta E_{\mathrm{CCSDT}(\mathrm{Q})}+\Delta E_{\mathrm{törzs}}^{\infty}+\Delta E_{\mathrm{ZPE}}+\Delta E_{\mathrm{DBOC}}+\Delta E_{\mathrm{REL}} .
$$

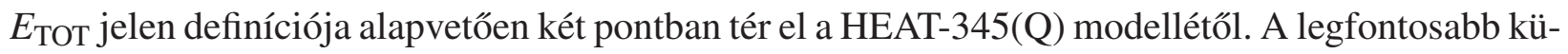
lönbség, hogy a korrelációs hozzájárulás számításánál különválasztottuk a törzs- és vegyértékelektronok kezelését, azaz a $\Delta E_{\mathrm{CCSD}(\mathrm{T})}^{\infty}$ tag számítása az FC közelítésen belül történt. A törzselektronok teljes korrelációs energiához történő hozzájárulását a kisebb bázissal számított $\Delta E_{\text {törzs }}^{\infty}$ tagban vettük figyelembe. A második alapvető különbség, hogy a HEAT-345(Q)-ban alkalmazott (aug-)cc$\mathrm{pVXZ}$ bázisokat a megfelelő szoros $d$-függvénnyel kiegészített (aug-)cc-pV $(X+d) \mathrm{Z}$ készletekre cseréltük a kénatom esetén.

A végtelen bázisra extrapolált HF végső energiát a Feller-féle 4.7 formulával közelítettük augcc-pV $(X+d) \mathrm{Z}(X=\mathrm{T}, \mathrm{Q}, 5)$ bázisokkal végzett számítások eredményeiből.

A vegyértékelektronok korrelációs járulékát, $\Delta E_{\mathrm{CCSD}(\mathrm{T})}^{\infty}$, FC-CCSD(T) energiák extrapolációjából kaptuk, melyek a HF-SCF energiát nem tartalmazták. A Helgaker-féle 4.2 összefüggéssel és az aug-cc-pV $(X+d) \mathrm{Z}(X=\mathrm{Q}, 5)$ bázisokkal számított eredményekből közelítettuik a korrelációs végső energiát.

A CCSDT(Q) magasabb rendű korrelációs hozzájárulást a következő különbséggel definiáltuk:

$$
\Delta E_{\mathrm{CCSDT}(\mathrm{Q})}=E_{\mathrm{CCSDT}(\mathrm{Q})}^{\mathrm{FC}}-E_{\mathrm{CCSD}(\mathrm{T})}^{\mathrm{FC}},
$$

ahol $E_{\mathrm{X}}^{\mathrm{FC}}$ jelöli az X módszerrel számított FC-CC energiát. Az alkalmazott bázis a cc-pV $(T+d) \mathrm{Z}$ készlet volt, a HEAT-345(Q) modellnél leírtaknak megfelelően. Vegyük észre, hogy a hozzájárulás magában foglalja az ezzel a bázissal számított $\Delta E_{\mathrm{CCSDT}}$ tagot is. A CCSDT(Q) módszer számítási igénye az alkalmazott bázis virtuális pályáinak számával meredeken növekszik. A skálázódás miatt 
az itt vizsgált legtöbb elektront tartalmazó $\mathrm{S}_{2} \mathrm{COH}$, $\mathrm{SCSOH}$ és $\mathrm{HOSO}_{2}$ gyökökre ezeket a számításokat nem tudtuk kivitelezni, a hozzájárulás becsléséhez közelítő módszert kellett alkalmaznunk. A közelítés alapja, hogy a kanonikus molekulapályák (MO) helyett MP2 szinten számított természetes pályákat (NO) használunk, melyek közül a kis betöltöttségúeket eldobjuk. A természetes pályákat az elsőrendû MP hullámfüggvényből származtatjuk, magát a módszert pedig MP2 FNO közelítésnek nevezzük (frozen natural orbitals). ${ }^{178-180}$ Landau és munkatársai, ${ }^{179}$ valamint Rolik és Kállay ${ }^{180}$ közelmúltban megjelent tanulmányai szerint, praktikus egy $\varepsilon$ küszöbérték definiálása, mely a virtuális NO-k MP2 szinten számított betöltési száma alapján állítható elő az alábbi módon. A virtuális NO-kat az MP2 betöltési számuk szerinti növekvő vagy csökkenő sorrendbe állítjuk. Minden egyes NO-hoz vesszük annak betöltési számát és elosztjuk az összes többi virtuális NO betöltési számainak összegével, azaz az adott NO betöltési számát a virtuális elektronok összes száma szerint normáljuk. Az így kapott eredményeket a nagyobb betöltésú NO-któl a kisebbek felé haladva összegezzük és mindaddig elhagyjuk a legkisebb betöltésú pályát, amíg $\varepsilon$ értéke el nem ér egy előre meghatározott küszöbértéket. Ha a küszöbértéket elértük, akkor az összes további kis betöltésú NO-t eldobjuk. Például, az $n_{a}>n_{b}>\cdots>n_{y}>n_{z}$ betöltési számú $a, b, \ldots y, z$ virtuális pályák esetén az alábbi módon járunk el:

$$
\begin{aligned}
\varepsilon_{1} & =\frac{n_{a}}{\sum_{\text {virt }} n}+\frac{n_{b}}{\sum_{\text {virt }} n}+\cdots+\frac{n_{y}}{\sum_{\text {virt }} n}+\frac{n_{z}}{\sum_{\text {virt }} n} \\
\varepsilon_{2} & =\frac{n_{a}}{\sum_{\text {virt }} n}+\frac{n_{b}}{\sum_{\text {virt }} n}+\cdots+\frac{n_{y}}{\sum_{\text {virt }} n}
\end{aligned}
$$

Nyilvánvalóan $\varepsilon_{1}>\varepsilon_{2}>\ldots$ és $\varepsilon_{1}=1$ esetben minden pályát figyelembe veszünk. $\mathrm{Az} \mathrm{S}_{2} \mathrm{COH}$, SCSOH és $\mathrm{HOSO}_{2}$ gyökök CCSD(T), CCSDT és CCSDT(Q) energiáit, valamint ezekből a $\Delta E_{\mathrm{CCSDT}(\mathrm{Q})}$ hozzájárulást különbözô $\varepsilon$ értékek mellett számítottuk, melyek közül a legnagyobb $\varepsilon$-hoz tartozó eredményt fogadtuk el. A közelítés minőségének jellemzéséhez a $\Delta E_{\mathrm{CCSDT}(\mathrm{Q})}$ járulékot $\varepsilon=1$ esetre extrapoláltuk, melynek az elfogadott értéktől való eltéréséből becsültük a hozzá tartozó hibát, melynek értékét hozzáadtuk a protokoll 4.3. fejezet szerint definiált bizonytalanságához.

A törzselektronok korrelációs járulékát, $\Delta E_{\text {törzs }}^{\infty}$, az AE- és FC-CCSD(T) energiák különbségével közelítettük. A határenergiát cc-pCVTZ és cc-pCVQZ bázisokkal számított eredményekből extrapoláltuk a Helgaker-féle formulával.

A zéruspont rezgési energiát a 4.8 összefüggés szerint állítottuk elő. Az $\omega_{i}$ harmonikus frekvenciákat CCSD(T)/cc-pVQZ, míg az $x_{i j}$ anharmonicitási konstansokat és a $G_{0}$ tagot $\operatorname{CCSD(T)/~}$ cc-pVTZ szinten számítottam.

A DBOC és a skaláris relativisztikus hatások számítása hasonlóan történt, mint a HEAT-345(Q) modell esetén, annyi különbséggel, hogy a jelen modellben alkalmazott bázisok nem tartalmaztak 
kiegészítő diffúz függvényeket. Azaz mindkét korrekciót a cc-pCVTZ készlettel, rendre CCSD és CCSD(T) szinteken határoztam meg. A relativisztikus hatások az egy- és kételektronos Darwintagon, valamint a tömeg-sebesség korrekción kívül a kénatom spin-pálya csatolásának hozzájárulását is tartalmazta, melyet a szénatomhoz hasonlóan a 4.3 ábrán látható séma szerint számítottunk.

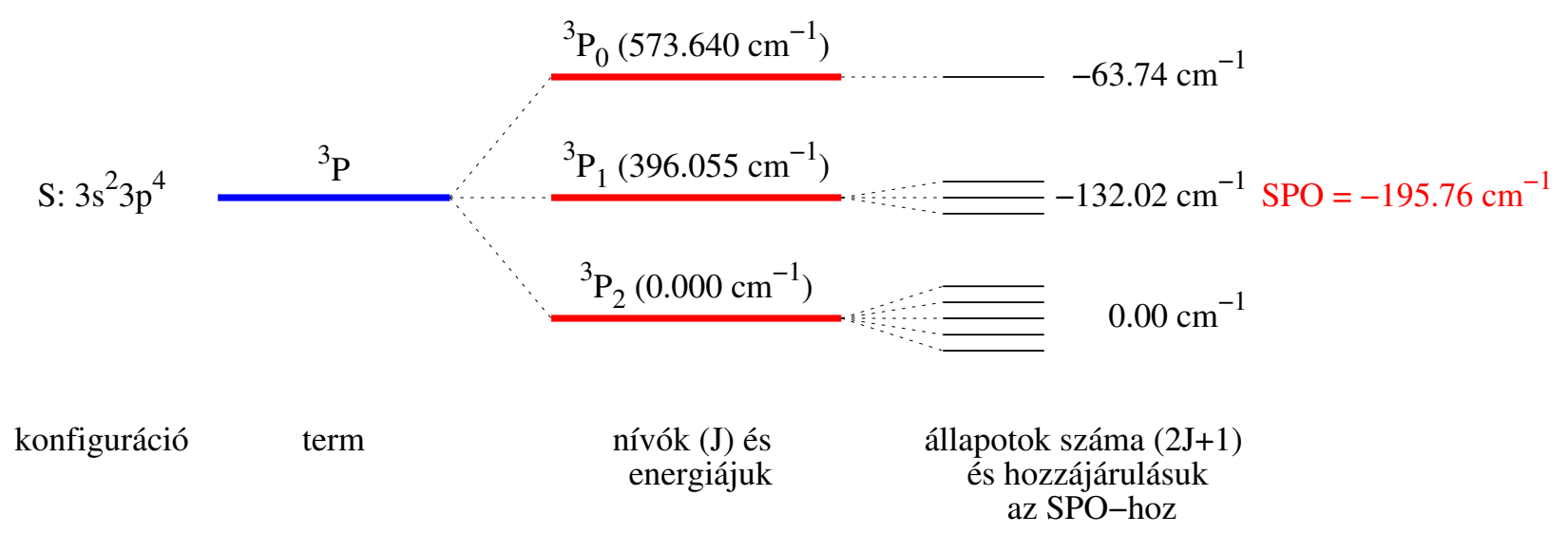

4.3. ábra

A kénatom spin-pálya csatolásának számítási sémája

\subsection{A termokémiai adatok számítása ab initio eredményekból}

Egy adott $T$ véges hőmérsékletre vonatkozó képződési entalpia, $\Delta_{f} H_{T}^{\circ}$, többféle bázison is felírható az ab initio modell szerint számított eredményekből. A formaldehid esetén ez a bázis az atomizációs reakció, valamint a $\mathrm{H}_{2}+\mathrm{CO}=\mathrm{H}_{2} \mathrm{CO}$ és a $\mathrm{H}_{2} \mathrm{O}+\mathrm{C}=\mathrm{H}_{2} \mathrm{CO}$ folyamatok voltak. A három közül a kizárólag zárt héjú molekulákat tartalmazó második reakció szolgáltatja a legpontosabb eredményeket, a másik kettô a $\mathrm{C}$ atom képzôdéshőjének használata miatt várhatóan bizonytalanabb eredményeket ad. Az atomizációs reakció bázisán $\Delta_{f} H_{T}^{\circ}$ az alábbiak szerint írható fel:

$$
\mathrm{H}_{2} \mathrm{CO}=2 \mathrm{H}+\mathrm{C}+\mathrm{O}
$$

amiből az atomizációs energia, $D_{T}^{\circ}$, és a képződési entalpia, $\Delta_{f} H_{T}^{\circ}, T$ hőmérsékleten:

$$
\begin{aligned}
D_{T}^{\circ}\left(\mathrm{H}_{2} \mathrm{CO}\right) & =2 H_{T}^{\circ}(\mathrm{H})+H_{T}^{\circ}(\mathrm{C})+H_{T}^{\circ}(\mathrm{O}) \\
\Delta_{f} H_{T}^{\circ}\left(\mathrm{H}_{2} \mathrm{CO}\right) & =2 \Delta_{f} H_{T}^{\circ}(\mathrm{H})+\Delta_{f} H_{T}^{\circ}\left(\mathrm{C}_{\text {gáz }}\right)+\Delta_{f} H_{T}^{\circ}(\mathrm{O})-D_{T}^{\circ}\left(\mathrm{H}_{2} \mathrm{CO}\right)
\end{aligned}
$$


ahol az atomi képződési entalpiák általában adatbázisokból származó nagy pontosságú kísérleti értékek. $\mathrm{A}_{2}+\mathrm{CO}=\mathrm{H}_{2} \mathrm{CO}$ reakciót alapul véve az alábbi módon járunk el:

$$
\begin{aligned}
\Delta_{r} H_{T}^{\circ} & =H_{T}^{\circ}\left(\mathrm{H}_{2} \mathrm{CO}\right)-H_{T}^{\circ}\left(\mathrm{H}_{2}\right)-H_{T}^{\circ}(\mathrm{CO}) \\
\Delta_{f} H_{T}^{\circ}\left(\mathrm{H}_{2} \mathrm{CO}\right) & =\Delta_{r} H_{T}^{\circ}+\Delta_{f} H_{T}^{\circ}(\mathrm{CO})
\end{aligned}
$$

ahol $\Delta_{r} H_{T}^{\circ}$ a reakciót kísérő entalpiaváltozás. Ezzel analóg módon a $\mathrm{H}_{2} \mathrm{O}+\mathrm{C}=\mathrm{H}_{2} \mathrm{CO}$ reakció esetén:

$$
\begin{array}{r}
\Delta_{r} H_{T}^{\circ}=H_{T}^{\circ}\left(\mathrm{H}_{2} \mathrm{CO}\right)-H_{T}^{\circ}\left(\mathrm{H}_{2} \mathrm{O}\right)-H_{T}^{\circ}\left(\mathrm{C}_{\text {gáz }}\right) \\
\Delta_{f} H_{T}^{\circ}\left(\mathrm{H}_{2} \mathrm{CO}\right)=\Delta_{r} H_{T}^{\circ}+\Delta_{f} H_{T}^{\circ}\left(\mathrm{H}_{2} \mathrm{O}\right)+\Delta_{f} H_{T}^{\circ}\left(\mathrm{C}_{\text {gáz }}\right)
\end{array}
$$

A fenti összefüggésekben $\mathrm{C}_{\text {gáz }}$ a gázfázisú szénatomot, mint referenciát jelöli, melynek használatát a 2.2. fejezetben már említettem. $\mathrm{A}_{\text {gáz }} 0 \mathrm{~K}$-en érvényes képződési entalpiája, $\Delta_{f} H_{0}^{\circ}\left(\mathrm{C}_{\text {gáz }}\right)$, a nagy pontosságú $711.64 \pm 0.32 \mathrm{~kJ} \mathrm{~mol}^{-1}$-es ab initio érték volt. ${ }^{36}$ A $298.15 \mathrm{~K}$-re vonatkozó adatot, $\Delta_{f} H_{298}^{\circ}\left(\mathrm{C}_{\text {gáz }}\right)=717.13 \pm 0.32 \mathrm{~kJ} \mathrm{~mol}^{-1}$, az NIST-JANAF ${ }^{19}$ adatbázisból származó $\Delta_{f} H_{298}^{\circ}-$ $-\Delta_{f} H_{0}^{\circ}=5.48 \mathrm{~kJ} \mathrm{~mol}^{-1}$ hőmérsékleti korrekció felhasználásával számítottam.

A formaldehid származékok és a kéntartalmú szpécieszek képződési entalpiáit az elemekből történô képződési reakciókból határoztam meg, ami a $\mathrm{CH}_{2} \mathrm{SO}$ gyök példáján keresztuil az alábbiak szerint következik, amennyiben a reakcióhőt az összefüggésben implicite szerepeltetjük:

$$
\begin{gathered}
\mathrm{C}+\mathrm{S}+\mathrm{H}_{2}+\frac{1}{2} \mathrm{O}_{2}=\mathrm{CH}_{2} \mathrm{SO} \\
\Delta_{f} H_{T}^{\circ}\left(\mathrm{CH}_{2} \mathrm{SO}\right)=H_{T}^{\circ}\left(\mathrm{CH}_{2} \mathrm{SO}\right)-H_{T}^{\circ}\left(\mathrm{C}_{\text {gáz }}\right)-H_{T}^{\circ}\left(\mathrm{S}_{\text {gáz }}\right)-H_{T}^{\circ}\left(\mathrm{H}_{2}\right)- \\
-\frac{1}{2} H_{T}^{\circ}\left(\mathrm{O}_{2}\right)+\Delta_{f} H_{T}^{\circ}\left(\mathrm{C}_{\text {gáz }}\right)+\Delta_{f} H_{T}^{\circ}\left(\mathrm{S}_{\text {gáz }}\right)
\end{gathered}
$$

ahol a fentiekhez hasonlóan $S_{\text {gáz }}$ jelöli a gázfázisú kénatomot, ami a kén valódi referenciaállapotát $\left(\mathrm{S}_{8}\right)$ helyettesíti. Képződéshőjének értéke $0 \mathrm{~K}$-en $277.25 \pm 0.3 \mathrm{~kJ} \mathrm{~mol}^{-1}$, $298.15 \mathrm{~K}$-en pedig $279.50 \pm 0.3 \mathrm{~kJ} \mathrm{~mol}^{-1}$, mely utóbbi az NIST-JANAF-ból származó hőmérsékleti korrekció szerint adódik. A 0 K-en érvényes adat forrásáról az alábbi 4.2.1. fejezetben foglalkozok.

A fenti összefüggésekben szereplő $H_{T}^{\circ}$ mennyiségek $T=0 \mathrm{~K}$-en az ab initio eredményekből közvetlenül következnek, mivel

$$
H_{(T=0 \mathrm{~K})}^{\circ}=E_{\mathrm{TOT}}
$$

ahol $E_{\mathrm{TOT}}$ a protokoll szerint előállított teljes energia atomi egységben $\left(E_{\mathrm{h}}\right)$. A $T$ véges hőmérsék- 
letre, általában 298.15 K-re vonatkozó adat a rendszer $U_{T}$ belsô energiájával írható fel,

$$
\begin{aligned}
& H_{T}^{\circ}=U_{T}^{\circ}+R T \\
& U_{T}^{\circ}=E_{\mathrm{TOT}}+\Delta E_{T}^{\mathrm{korr}}
\end{aligned}
$$

ahol $R$ az egyetemes gázállandó atomi egységben $\left(E_{\mathrm{h}} \mathrm{mol}^{-1} \mathrm{~K}^{-1}\right)$ és $T$ a hômérséklet $\mathrm{K}$-ben. $\Delta E_{T}^{\mathrm{korr}}$ az atomi egységben vett adott $T$-re vonatkozó hômérsékleti korrekció, mely transzlációs, rotációs, vibrációs és elektronikus hozzájárulások összegéből származik. Ezeket a statisztikus termodinamika standard összefüggései szerint, az RRHO közelítés alkalmazásával számítjuk ideális gáz állapotot feltételezve. ${ }^{169,181} \Delta E_{T}^{\text {korr }}$ különböző hozzájárulásainak meghatározásához a számított harmonikus frekvenciákat és rotációs konstansokat használtuk, valamint minden esetben feltételeztuik azt, hogy a molekula első gerjesztett állapota energetikailag jóval magasabban helyezkedik el az alapállapotnál. Ezzel az elektronikus hozzájárulás az állapotösszeghez zérus, kivéve azokban az esetekben, ahol figyelembe kell vennünk a gátolt rotációt, illetve egyes atomok és lineáris molekulák esetén a spin-pálya felhasadást.

$\Delta E_{T}^{\mathrm{korr}}$ értékeiből a kJ mol${ }^{-1}$-ben érvényes hőmérsékleti korrekciókat $\left(H_{T}^{\circ}-H_{0}^{\circ} \equiv H_{T}^{\mathrm{korr}}\right)$ a

$$
H_{T}^{\mathrm{korr}}=\Delta E_{T}^{\mathrm{korr}}+R T
$$

összefüggés szerint számítjuk, ahol $\Delta E_{T}^{\mathrm{korr}}$-t, valamint az $R T$ szorzatot $\mathrm{kJ} \mathrm{mol}^{-1}$ egységben szerepeltetjük. Egy tetszőleges $\mathrm{M}$ molekulára, melynek $\Delta_{f} H_{0}^{\circ}(\mathrm{M})$ és $H_{T}^{\mathrm{korr}}$ értékei, továbbá $\mathrm{M} \mathrm{REF}_{i}$ atomjainak, mint referenciáknak ugyanezen mennyiségei ismertek, akkor egy tetszőleges $T$ hőmérsékletre:

$$
\begin{array}{r}
\Delta_{f} H_{T}^{\circ}(\mathrm{M})=\Delta_{f} H_{0}^{\circ}(\mathrm{M})+H_{T}^{\mathrm{korr}}(\mathrm{M})-\sum_{i} v_{i} H_{T}^{\mathrm{korr}}\left(\mathrm{REF}_{i}\right)+ \\
+\sum_{i} v_{i}\left[\Delta_{f} H_{T}^{\circ}\left(\mathrm{REF}_{i}\right)-\Delta_{f} H_{0}^{\circ}\left(\mathrm{REF}_{i}\right)\right]
\end{array}
$$

összefüggés szerint adhatjuk meg a képződési entalpiát, ahol $v_{i}$ az $i$-edik atom darabszáma a kérdéses molekulában.

A standard moláris entrópia, $S_{T}^{\circ}$, az atomi egységben számított $\Delta S_{T}$ adat $\mathrm{J} \mathrm{K}^{-1} \mathrm{~mol}^{-1}$ egységre konvertálásával adható meg, ahol utóbbi mennyiség a $\Delta E_{T}^{\mathrm{korr}}$-hoz hasonlóan a statisztikus termodinamika összefüggései ${ }^{169,181}$ szerint adható meg. Ennek ismeretében a molekulák szabadenergiája $\left(A_{T}^{\circ}\right)$, és szabadentalpiája $\left(G_{T}^{\circ}\right)$ atomi egységekben a termodinamika egyszerú összefüggései alapján számíthatók:

$$
\begin{aligned}
& A_{T}^{\circ}=U_{T}^{\circ}-T \Delta S_{T} \\
& G_{T}^{\circ}=A_{T}^{\circ}+H_{T}^{\circ}-U_{T}^{\circ}
\end{aligned}
$$


Az 5.7.3. fejezetben részletesen foglalkozok a $\mathrm{CS}_{2}+\mathrm{OH} \rightleftharpoons \mathrm{S}_{2} \mathrm{COH}$ reakcióval, ahol a termék szerkezetére vonatkozó korábbi elméleti és kísérleti adatok ellentmondásosak. Az egyik feltételezés szerint a reakcióban $\mathrm{S}_{2} \mathrm{COH}$, míg a másik szerint a szerkezeti izomer SCSOH képződik. Az ellentmondások feloldása érdekében kiszámítottam a kérdéses folyamatra vonatkozó standard reakcióhőt, -entrópiát, -szabadentalpiát, valamint az egyensúlyi állandót. A reakcióra vonatkozó ezen mennyiségek 298.15 K-en a termodinamika alapvető összefüggései szerint adhatók meg:

$$
\begin{aligned}
\Delta_{r} H_{298}^{\circ} & =\Delta_{f} H_{298}^{\circ}(\mathrm{M})-\Delta_{f} H_{298}^{\circ}\left(\mathrm{CS}_{2}\right)-\Delta_{f} H_{298}^{\circ}(\mathrm{OH}) \\
\Delta_{r} S_{298}^{\circ} & =S_{298}^{\circ}(\mathrm{M})-S_{298}^{\circ}\left(\mathrm{CS}_{2}\right)-S_{298}^{\circ}(\mathrm{OH}) \\
\Delta_{r} G_{298}^{\circ} & =\Delta_{r} H_{298}^{\circ}-T \Delta_{r} S_{298}^{\circ} \\
\ln K & =\frac{-\Delta_{r} G_{298}^{\circ}}{R T}
\end{aligned}
$$

ahol M jelöli az $\mathrm{S}_{2} \mathrm{COH}-t$ vagy az SCSOH-t, és $\Delta_{f} H_{298}^{\circ}(\mathrm{M}), S_{298}^{\circ}(\mathrm{M})$, valamint ezekből a

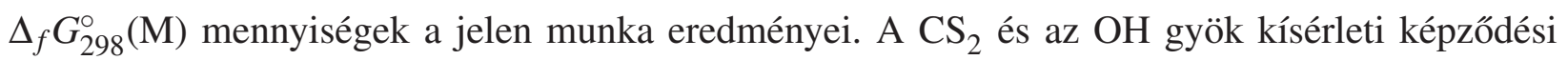
entalpiája és entrópiája a JPL adatbázisból ${ }^{20}$ származik.

\subsubsection{A gázfázisú kénatom mint referenciaállapot képződéshôje}

A HEAT-345 $+d(\mathrm{Q})$ tesztmodellekkel számított eredmények kiértékelésekor jelentős eltéréseket tapasztaltam a tesztkészlet $\Delta_{f} H_{298}^{\circ}$ és $\Delta_{f} H_{0}^{\circ}$ adatainak kísérleti, valamint a jelen munka során meghatározott elméleti értékei között, ami a gázfázisú kénatom NIST-JANAF képződési entalpiájából származott. A kérdéses adat Ricks és Barrow ${ }^{182}$ 1969-es munkáján alapul, melyben a szerzők az S 2 molekula disszociációs energiájára a $D_{0}^{\circ}\left(\mathrm{S}_{2}\right)=35216.4 \pm 2.5 \mathrm{~cm}^{-1}$-es értéket közölték. 2009-ben Frederix és munkatársai ${ }^{183}$ egy újabb kísérleti adatot, $35636.9 \pm 2.5 \mathrm{~cm}^{-1}$, publikáltak a molekula disszociációs energiájára, melyet kombinálva a korábbi eredménnyel, egy új $\Delta_{f} H_{0}^{\circ}\left(\mathrm{S}_{\text {gáz }}\right)$ értéket vezettünk be és javasoltunk későbbi felhasználásra. Az újabb, 2009-es eredmény helyességét támasztja alá egyrészt a saját számított adatunk, $35602.5 \pm 250.8 \mathrm{~cm}^{-1}$, valamint a szintén elméleti úton meghatározott, Feller és csoportja ${ }^{77}$ által közölt $35585.7 \pm 104.9 \mathrm{~cm}^{-1}$-es érték is.

Jelen munkában referenciaként használt és a késôbbi számításokhoz is javasolt $\Delta_{f} H_{0}^{\circ}\left(\mathrm{S}_{\mathrm{gáz}}\right)$ adatot a 4.30 összefüggés szerint származtattuk:

$$
\begin{gathered}
\Delta_{f} H_{0}^{\circ}\left(\mathrm{S}_{\text {gáz }}\right)=\Delta_{f} H_{0}^{\circ}\left(\mathrm{S}_{\text {gáz }}, \mathrm{NIST}\right)-0.5 \cdot \Delta D_{0}^{\circ} \\
\Delta D_{0}^{\circ}=D_{0}^{\circ}\left(\mathrm{S}_{2}, \text { Ricks }\right)-D_{0}^{\circ}\left(\mathrm{S}_{2}, \text { Frederix }\right)=-420.5 \mathrm{~cm}^{-1}
\end{gathered}
$$

ahol $\Delta_{f} H_{0}^{\circ}\left(S_{\text {gáz }}\right.$, NIST $)=274.73 \pm 0.25$ a jelenleg elfogadott NIST-JANAF képződéshő. A 4.30 szerint elóálló új $\Delta_{f} H_{0}^{\circ}\left(\mathrm{S}_{\text {gáz }}\right)=277.25 \pm 0.3 \mathrm{~kJ} \mathrm{~mol}^{-1}$-es adattal, illetve ennek $298.15 \mathrm{~K}$-en vett megfelelőjével, $279.50 \pm 0.3 \mathrm{~kJ} \mathrm{~mol}^{-1}$, a kísérletiekkel kiválóan egyező eredményeket értem el a tesztmodellek alkalmazásával. 
A fenti módon bevezetett atomi képződéshôt több tanulmány ${ }^{184-186}$ is felhasználta referencia minőségú adatok számításához.

\subsubsection{Az RRHO közelítés korrekciója}

A gátolt rotációval jellemezhetô molekulák és gyökök esetén az RRHO modellel kapott eredményeink, nevezetesen a hőmérsékleti korrekciók és entrópiaadatok, valamint a zéruspont rezgési energiák korrekcióra szorulnak. Ezek számításához egy egydimenziós gátolt rotátor modellt használtunk. ${ }^{187-192}$ Az ehhez tartozó egydimenziós Schrödinger-egyenlet:

$$
-\frac{\hbar^{2}}{2 I_{r}} \frac{\mathrm{d}^{2}}{\mathrm{~d} \theta^{2}} \Psi+V(\theta) \Psi=E \Psi
$$

ahol $I_{r}$ a redukált tehetetlenségi nyomaték, $V(\theta)$ pedig a potenciális energia, ami a konformációs analízisek eredményeiból származik. 4.31 megoldása Marston és Bálint-Kürti módszerén ${ }^{193,194}$ alapul. A potenciál analitikus formában történő felírásához $V(\theta)$-t Fourier-sorba fejtjük:

$$
V(\theta)=c+\sum_{i=1}^{6}\left\{a_{i} \cos (i \theta)+b_{i} \sin (i \theta)\right\}
$$

$I_{r}$-t a 195 és 196 referenciákban leírt frekvenciaséma szerint számítjuk és $\theta$-tól való függését elhanyagoljuk. Végül a gátolt rotátor állapotösszegét direkt sajátértékösszegzéssel kapjuk, és ezzel korrigáljuk az RRHO szerint számított adatainkat.

\subsection{Az entalpia- és entrópiaértékek hibahatárai}

Az elméleti úton származtatott mennyiségekhez tartozó bizonytalanságok becslése nem minden esetben nyilvánvaló feladat. A legkonzisztensebb és elméletileg a legmegalapozottabb hibák nagy számú adatot használó statisztikai analízissel nyerhetôk, azonban a komoly számítási igény miatt erre sokszor nincs lehetőség. Amennyiben a kompozit módszerünkben minden hozzájáruláshoz pontos hibát is ismerünk, akkor megbízható bizonytalanságok adhatók meg a végeredményekhez, sôt, a hibák előjeles összegzése során kompenzációk figyelembevételére is lehetőségünk van.

A dolgozatban szereplő termokémiai adatok bizonytalanságát az FPA és a HEAT modellek esetén eltérően kezeltük. Az FPA-nál a teljes energia minden egyes hozzájárulásához külön-külön becsüljük azok bizonytalanságát, majd kompenzációkat is figyelembe véve adjuk meg a modell eredményeihez tartozó konzervatív hibát. A formaldehid képződéshőjéhez tartozó hibáról az egyes hozzájárulások részletes tárgyalásánál lesz szó az Eredmények és értékelésük fejezet megfelelő pontjaiban.

Az FPA hozzájárulásonkénti hibabecsléséhez képest a HEAT modellek statisztikai alapon meghatározott bizonytalanságokat használnak. Ezek meghatározásánál a teljes modellel meghatározott 
adatokat használjuk, azaz a hibát a modell egészére vonatkoztatjuk és nem annak hozzájárulásai szerint tekintjük.

A dolgozatban használt HEAT modellek hibáit egy korábbi, klórozott és fluorozott szénhidrogénekkel foglalkozó tanulmány ${ }^{177}$ definiálja. A kérdéses cikkben egy 26 molekulából álló referenciakészletre végeztek számításokat az itteni modellekkel, pontosabban a HEAT-345(Q)-val és a fentebb definiált 1. modellel. A 26 molekula közül 17 olyan első periódusbeli elemekből felépülő szpéciesz volt, mely része a HEAT tesztkészletnek. ${ }^{51}$ A további 9 klórtartalmú vegyület kísérleti adatbázisokból származik. Mindegyikük experimentális képződési entalpiája nagy pontossággal elérhetô.

A HEAT-345(Q) modell négyzetes közepes eltérése az első periódusbeli 17 szpécieszre 0.39 $\mathrm{kJ} \mathrm{mol}^{-1}$-nek adódott $0.72 \mathrm{~kJ} \mathrm{~mol}^{-1}$ maximális eltéréssel, míg a 9 klórtartalmú vegyület esetén a statisztikai jellemzók rendre 0.41 és $0.58 \mathrm{~kJ} \mathrm{~mol}^{-1}$ voltak. A molekula méretétől független hiba megadható, ha az eltéréseket egyetlen atomra vonatkoztatjuk. A per-atom bázison számított bizonytalanságok a HEAT-345(Q) modell esetén rendre 0.16 , valamint $0.41 \mathrm{~kJ} \mathrm{~mol}^{-1}$-nek adódtak az első periódusbeli, valamint a klóratomokra vonatkoztatva. A 95\%-os konfidencia intervallum közelítése és a képződéshőkhöz tartozó hiba konzervatív becslése érdekében az atomonkénti négyzetes közepes eltérések kétszeresét vettem. Így minden egyes elsô periódusbeli elemhez a 0.3 , míg minden klóratomhoz a $0.8 \mathrm{~kJ} \mathrm{~mol}^{-1}$-es hiba tartozik, melyek egy adott molekulára felösszegzünk. Azaz például a $\mathrm{HClCO}$ esetén a hiba $0.3+0.8+0.3+0.3=1.7 \mathrm{~kJ} \mathrm{~mol}^{-1}$. Az $S_{298}^{\circ}$ adatokhoz tartozó hiba szintén egy statisztikai analízis eredménye, ahol a HEAT-345(Q) protokoll $0.6 \mathrm{JK}^{-1} \mathrm{~mol}^{-1}$-es négyzetes közepes eltéréssel teljesített. Ebből a konzervatív $1.5 \mathrm{JK}^{-1} \mathrm{~mol}^{-1}$-es bizonytalanság származtatható.

Az 1. modell, azaz a szoros- $d$ függvények nélküli HEAT-345+d(Q) protokoll képződési entalpiái esetén az atomonkénti hiba a 95\%-os konfidencia intervallumnak megfelelően 0.4 és 1.5 $\mathrm{kJ} \mathrm{mol}^{-1}$-nek adódott az elsô periódusbeli elemek atomjait, valamint a klóratomokat tartalmazó molekulák esetén. Az így definiált $1.5 \mathrm{~kJ} \mathrm{~mol}^{-1}$-es hibát kiterjesztettük a kénatomra a HEAT$345+d(\mathrm{Q})$ modell esetén, és ennek helyességét a tesztkészlet molekuláin keresztül ellenôriztem. Az entrópiaadatokhoz tartozó hibahatár a HEAT-345(Q) modellnél bevezetett $1.5 \mathrm{~J} \mathrm{~K}^{-1} \mathrm{~mol}^{-1}$-es érték volt.

\subsection{A számításokhoz használt programok, programcsomagok}

\subsubsection{Az FPA modell}

Az FPA modellben szereplő explicite korrelált számítások a DIRCCR12-Os ${ }^{197}$ programmal készültek. A magasabb rendú korrelációs hozzájárulásokat az MRCC, ${ }^{59}$ míg a relativisztikus DKH komponenseket a MOLPRO ${ }^{198}$ programokkal számítottuk. A globális PES illesztéséhez használt ab initio energiák szintén a MOLPRO csomag eredményei. A variációs magmozgás számítások a 
Multimode (MM) ${ }^{199}$ programmal készültek. Az összes többi számítás az ACESII-MAB ${ }^{157}$ programmal készült. $\ddagger$

Az elektronszerkezeti számítások legnagyobb része a Szegedi Tudományegyetemen, Tasi Gyula számítógépein futottak.

\subsubsection{A HEAT modellek}

A formaldehid származékainak HF-SCF/aug-cc-pCV6Z számításai a MOLPRO ${ }^{198}$ kvantumkémiai programcsomag direkt integrálszámító rutinjának használatával futottak az NIIF Infrastruktúra debreceni szuperszámítógépén. Mindkét HEAT-típusú modell esetén a CCSDT(Q) futásokat az MRCC $^{59}$ programmal végeztem, míg az összes többi elektronszerkezeti számítás a CFOUR ${ }^{200}$ programcsomaggal készült. A statisztikus termodinamikai számítások a Csontos József által Python nyelven írt szkripttel ${ }^{201}$ történtek, mely a CFOUR harmonikus vagy harmonikus és anharmonikus futásának eredményfájlját használja. A szkript a 181 referenciában szereplő összefüggések szerint számítja a kérdéses mennyiségeket. Az RRHO közelítés korrekcióinak számításához Csontos József programját használtam. A számítások bemeneti fájljainak előállításához, valamint a nyers számítási adatok kinyeréséhez, helyességük ellenőrzéséhez, feldolgozásához és kiértékeléséhez számos saját szkriptet és egyszerúbb rutint használtam.

A számítások döntô része a BME Fizikai Kémiai és Anyagtudományi Tanszékén, a Spektroszkópia Csoport Linux klaszterén futottak.

${ }^{\ddagger}$ Az ACESII-MAB kód fejlesztése leállt, a projekt CFOUR ${ }^{200}$ néven fut tovább. 


\section{Eredmények és értékelésük}

\subsection{Egyensúlyi geometria}

A teljes energia egyes hozzájárulásainak számításánál a 4. fejezetben, az egyes modellek ismertetésénél leírtak szerint CCSD(T)/cc-pVQZ (HEAT modellek) és CCSD(T)/aug-cc-pCVQZ (FPA modell) szintú egyensúlyi geometriákat használtunk. Az optimalizálás során egyik esetben sem alkalmaztuk a „,befagyasztott mag” közelítést, azaz a molekulák összes elektronjának korrelációját figyelembe vettük. A számított geometriai paraméterek, a kötéshosszak, kötésszögek, valamint a torziós szögek értékeit a Függelék F. 1. táblázatában láthatjuk, míg az 5.1. ábra grafikusan mutatja be a molekulák szerkezetét.

Egy korábbi tanulmány ${ }^{164}$ szerint - melyet azóta több munka, ${ }^{17,177,202}$ és a HEAT modellek ${ }^{51-53}$ is alátámasztottak - a CCSD(T)/cc-pVQZ elméleti szint alkalmazása a geometriai optimalizálásokban elegendően pontos a termokémiai adatok számításához: a kötéstávolságokat ugyanis $<0.003 \AA$ A a kötésszögeket pedig $<0.5^{\circ}$ pontossággal adja vissza.

A CCSD(T) elméleti szinten számított szerkezetek pontosságának szemléltetése, illetve annak ellenőrzése érdekében szukcesszív optimalizálásokat végeztem a formaldehid molekulára. A számításokat a szisztematikusan növekedő Dunning-féle bázisokkal végeztem, a cc-pVDZ készlettel kezdve az aug-cc-pCV5Z-ig. Az eredményeket bemutató 5.2. ábrán, valamint az optimált geometriai paramétereket listázó F. 2. táblázatban egyaránt jól látható, hogy a $C-H$ és $C=O$ kötéstávolságok alig változnak a cc-pVQZ-nél nagyobb bázisok alkalmazása esetén. A készletek diffúz függvénnyel történő kiegészítése, valamint a törzselektronok korrelációjának a bázisfüggvényekben való kezelése [(aug-)cc-pCVXZ] az X kardinális szám növelésével veszít jelentôségéből. A bázisfüggvények számának növelésénél sokkal jelentősebb hatással bír a törzs- és vegyértékelektronok szétválasztása a korrelációs számításokban. Az előbbiek befagyasztásával a cc-pVXZ ( $X=$ $=\mathrm{D}, \mathrm{T}, \mathrm{Q}, 5)$ bázisokkal végzett $\mathrm{CCSD}(\mathrm{T})$ optimalizálások határozottan pontatlanabb geometriákat eredményeztek, mint az összes elektron korrelációját kezelő számítások. Mindazonáltal érdemes megjegyezni, hogy egy adott kardinális számnál a $\mathrm{H}-\mathrm{C}=\mathrm{O}$ kötésszög kevésbé érzékeny a bázisra, mint a két kötéstávolság (5.2c. ábra). Itt a diffúz függvények hatása ugyan intenzívebb, de ez gyakorlatilag nem függ a bázis kardinális számától.

A különböző bázisokkal optimalizált egyensúlyi geometriák további vizsgálata céljából CCSD(T)/aug-cc-pCVQZ abszolút energiákat számítottam a különböző szinteken előálló szerke- 


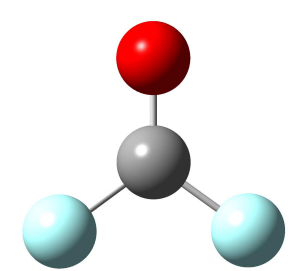

(a) $\mathrm{F}_{2} \mathrm{CO}$

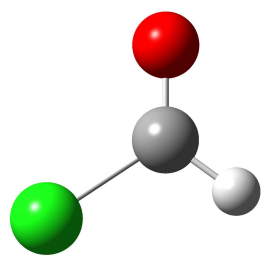

(d) $\mathrm{HClCO}$

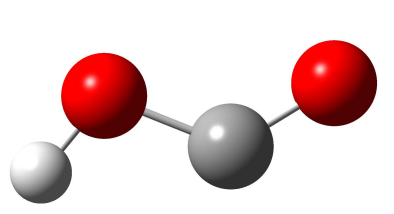

(g) transz-HOCO

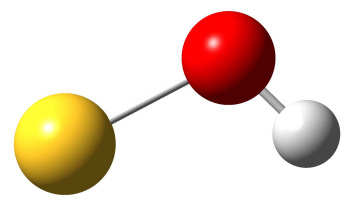

(j) $\mathrm{SOH}$

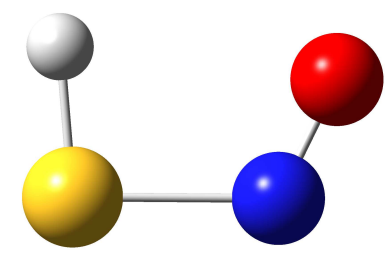

(m) cisz-HSNO

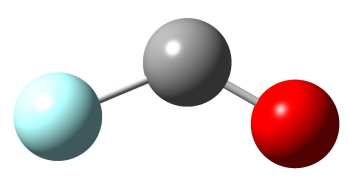

(b) $\mathrm{FCO}$

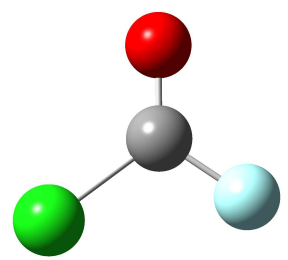

(e) $\mathrm{FClCO}$

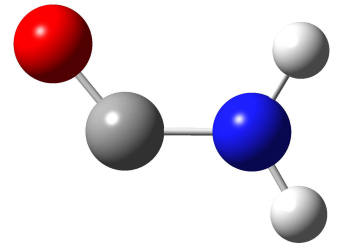

(h) $\mathrm{NH}_{2} \mathrm{CO}$

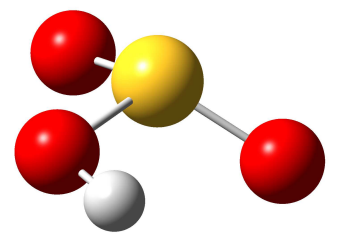

(k) $\mathrm{HOSO}_{2}$

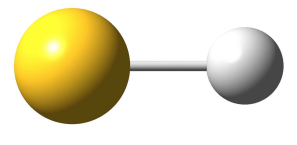

(n) $\mathrm{SH}$

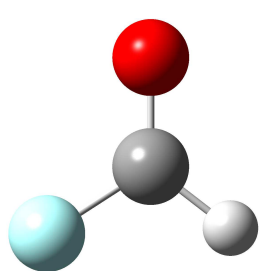

(c) $\mathrm{HFCO}$

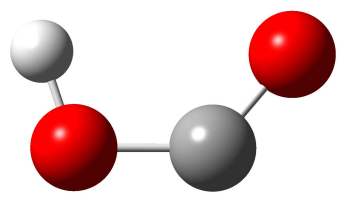

(f) cisz-HOCO

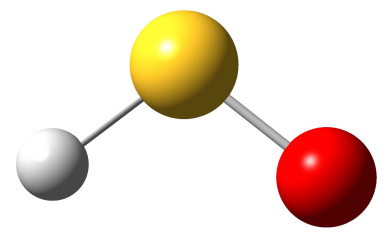

(i) $\mathrm{HSO}$

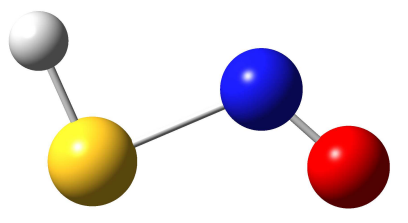

(1) transz-HSNO

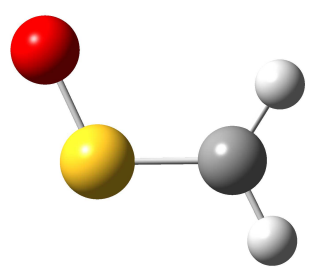

(o) $\mathrm{CH}_{2} \mathrm{SO}$

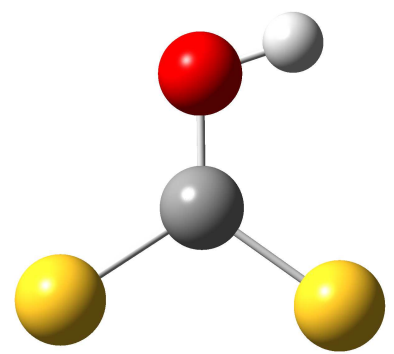

(r) $\mathrm{S}_{2} \mathrm{COH}$

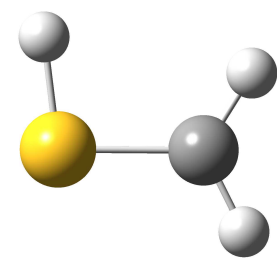

(p) $\mathrm{CH}_{2} \mathrm{SH}$

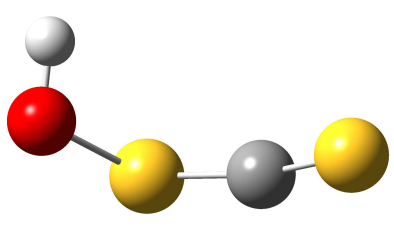

(q) $\mathrm{SCSOH}$

5.1. ábra

A dolgozatban vizsgált gyökök és molekulák egyensúlyi geometriája. A CCSD(T)/cc-pVQZ szinten optimalizált szerkezeti paramétereket lásd az F. 1. táblázatban 


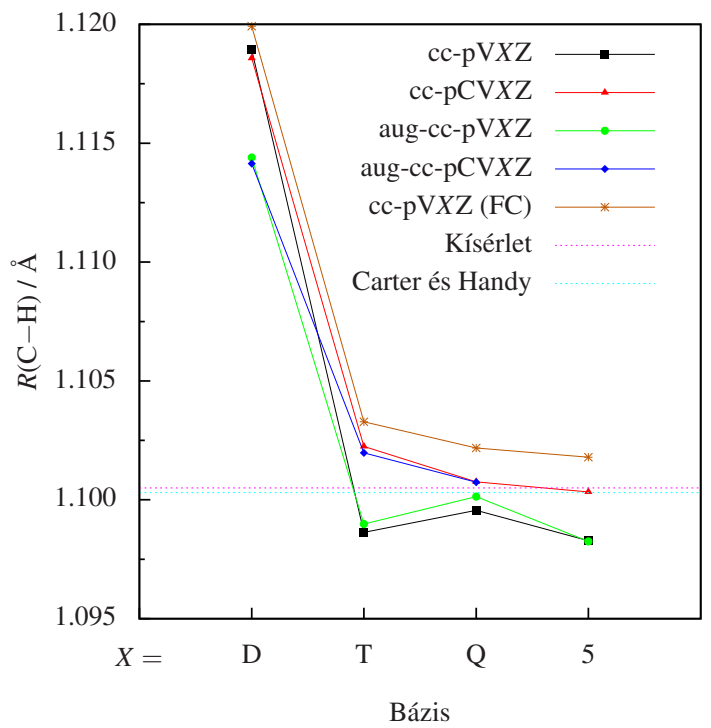

(a) A C-H kötéshossz valtozása a bázis függvényében

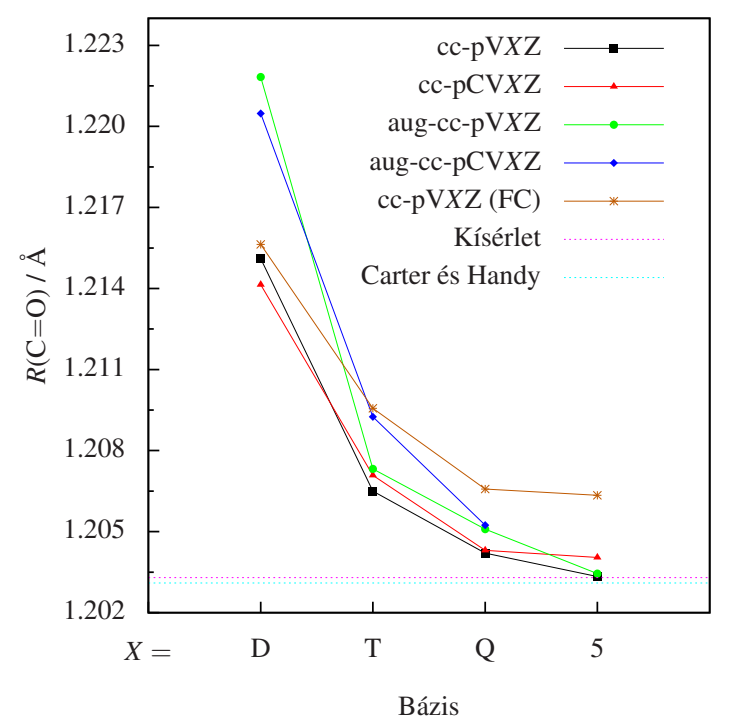

(b) A C = O kötéshossz valtozása a bázis függvényében

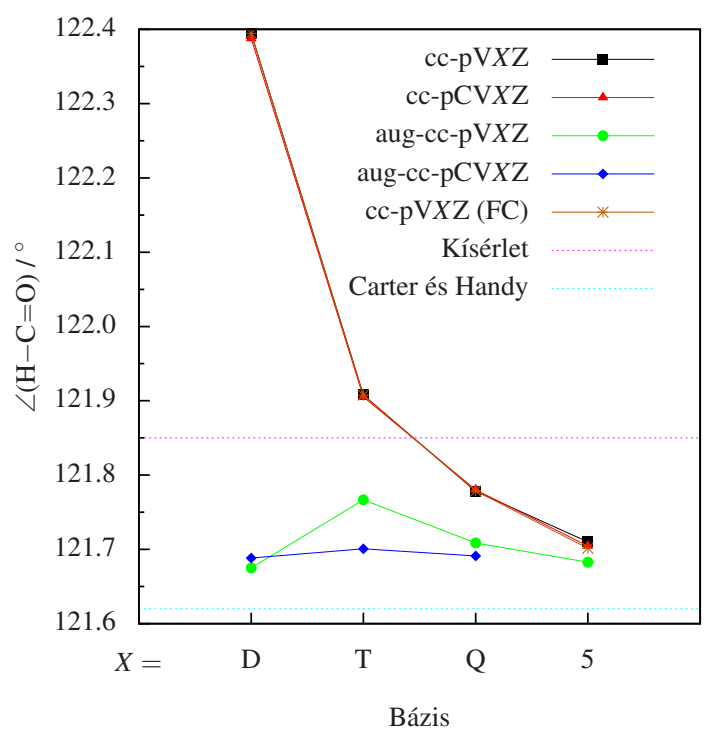

(c) $\mathrm{A} \mathrm{H}-\mathrm{C}=\mathrm{O}$ kötésszög valtozása a bázis függvényében

\section{2. ábra}

A formaldehid különböző bázisokkal számított egyensúlyi geometriája. A kísérleti adatok a 203. referenciából származnak.

zeteken. Az 5.3. ábrán jól látható, hogy a CCSD(T)/cc-pVTZ szint felett meghatározott geometriai paraméterek esetén az energia gyakorlatilag nem változik, ami alapján azt mondhatjuk, hogy a szerkezeti jellemzők már ezen a szinten elérik konvergenciájukat. Ez azt jelenti, hogy a bázis növelésével a kötéshosszak néhány ezred Å-ös, valamint a kötésszögek néhány század fokos változása az abszolút elektronenergiát már nem befolyásolja. Az ilyen kis mértékú eltérések csupán a rezgési frekvenciák, illetve az ezekből származtatott zérusponti energiák és az állapotösszegek rezgési hozzájárulásának számítási pontosságában játszhatnak szerepet. 


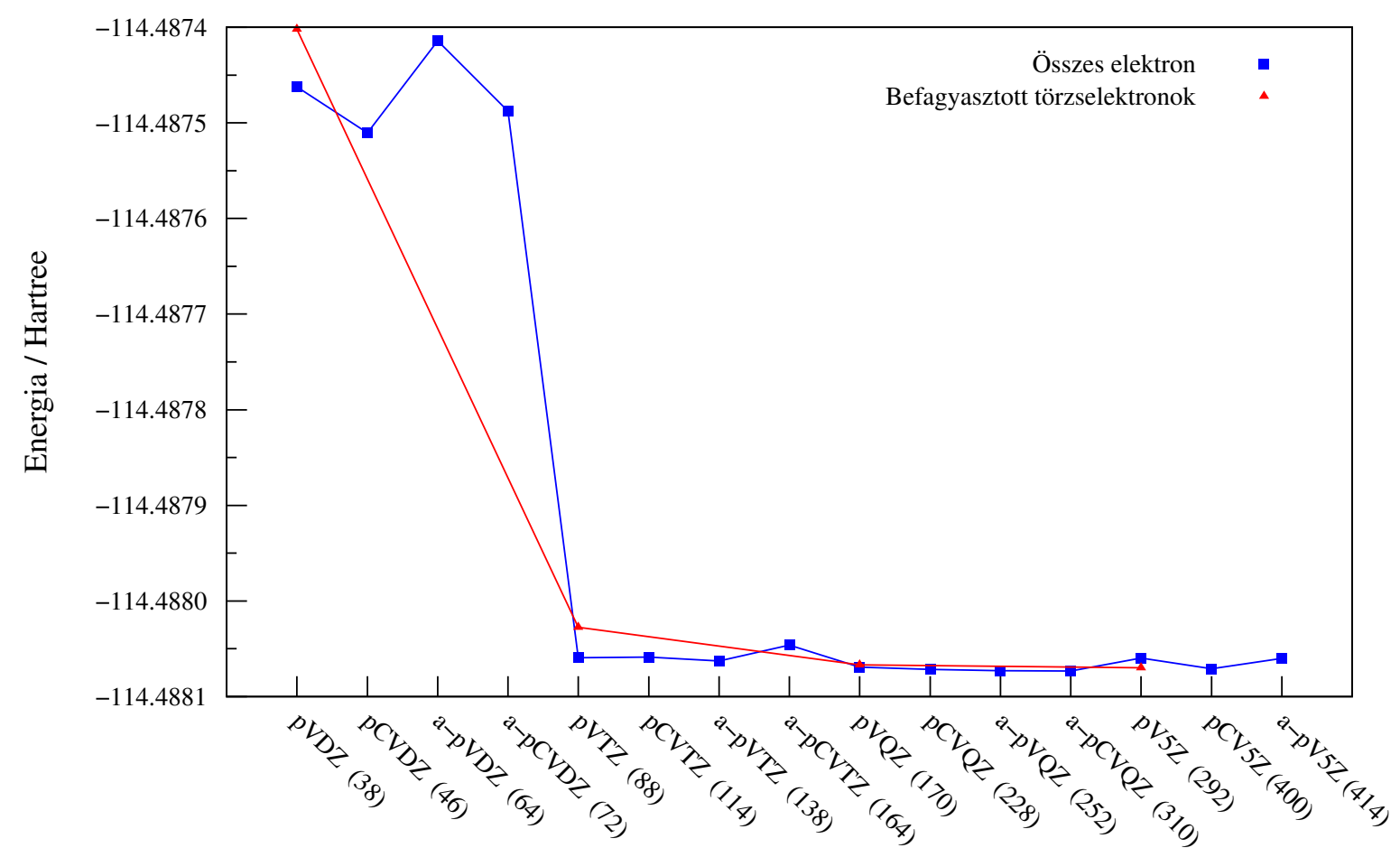

Az optimalizálás bázisa (bázisfüggvények száma)

5.3. ábra

A CCSD(T)/aug-cc-pCVQZ energia változása a különböző bázisokkal optimalizált szerkezetek függvényében

A jelen munkában referenciaként használt CCSD(T)/cc-pVQZ és aug-cc-pCVQZ szintú geometriákat összevetve a rendelkezésre álló kísérleti paraméterekkel kiváló egyezést tapasztalhatunk (5.1. táblázat).

5.1. táblázat

A formaldehid molekula jelen munkában számított, valamint néhány válogatott irodalmi szerkezeti paraméterei

\begin{tabular}{lcccl}
\hline \hline Referencia & $R(\mathrm{C}-\mathrm{H}) / \AA$ & $R(\mathrm{C}=\mathrm{O}) / \AA$ & $\angle(\mathrm{H}-\mathrm{C}=\mathrm{O}) /{ }^{\circ}$ & \multicolumn{1}{c}{ Megjegyzés } \\
\hline \hline Jelen munka & 1.09956 & 1.20421 & 121.78 & cc-pVQZ \\
Jelen munka & 1.10013 & 1.20509 & 121.71 & aug-cc-pCVQZ \\
Yamada et al. $^{204}$ & 1.099 & 1.203 & 121.75 & kísérlet \\
Duncan $^{203}$ & 1.1005 & 1.2033 & 121.85 & kísérlet \\
Carter és Handy $^{205}$ & 1.1003 & 1.2031 & 121.62 & illesztés \\
\hline \hline
\end{tabular}

A formaldehid esetén mindkét bázissal meghatározott szerkezet jól reprodukálja egyrészt a Duncan-féle, ${ }^{203}$ másrészt a szintén gyakran hivatkozott Yamada és társai ${ }^{204}$ által mért eredményeket. Az 5.2. ábrán a Duncan-féle kísérleti geometria mellett a Carter és Handy által számított ${ }^{205}$ paramétereket is feltüntettem. A szerző́k a molekula szerkezetét és kvadratikus erôterét illesztették 
a $\mathrm{H}_{2} \mathrm{CO}$ és a $\mathrm{D}_{2} \mathrm{CO}$ kísérleti rezgési-forgási adataira. Eredményeik szintén jó összhangban vannak az itt közöltekkel. Közleményük (205 referencia) 1. táblázatában számos alacsonyabb szinten optimalizált szerkezeti paraméter található.

A 4.1.3 fejezetben bemutatott HEAT-345+d(Q) modell kidolgozásánál külön vizsgáltuk a szoros- $d$ függvények hatását a kéntartalmú rendszerek geometriai paramétereire (3. modell). A tesztkészlet CCSD(T)/cc-pVQZ és CCSD $(\mathrm{T}) / \mathrm{cc}-\mathrm{pV}(\mathrm{Q}+d) \mathrm{Z}$ szinten számított egyensúlyi szerkezetei a Függelék F. 3. táblázatában láthatók. A szoros- $d$ függvények a geometriát csak igen kis mértékben módosítják, így ezek használata az optimalizálás során nem indokolt. Mindezt alátámasztja az 5.19. táblázat, valamint az 5.5. ábra is. A két különböző geometrián, ugyanazon protokoll szerint számított entalpiaértékek alig, mindössze 0.1-0.2 kJ mol-1 -gyel térnek el egymástól. Továbbá ha számított geometriáinkat összevetjük az NIST-JANAF táblázat ${ }^{19}$ kísérleti adataival (F. 4. táblázat), láthatjuk, hogy mindkét bázis esetén kötéshosszaink mindössze néhány ezred Å-mel, kötésszögeink pedig néhány tized fokkal térnek el az irodalmiaktól. Mindenképpen említést érdemel Martin 1998-as munkája, ${ }^{206}$ melyben a szerző az $\mathrm{SO}_{2}$ molekula geometriáján, atomizációs energiáján és anharmonikus erőterén keresztül tanulmányozza a nagy exponensű $d$ - és $f$-típusú függvények hatását. Konklúziója szerint a kénatom bázisához adott kiegészítő szoros- $d$ (és $-f$ ) függvények fooleg a HF-SCF számítások helyes konvergenciájának biztosításában játszanak szerepet, hatásuk túlnyomó része a számított atomizációs energiára ezen a szinten manifesztálódik. Mindezek alapján kijelenthetjük, hogy a CCSD(T)/cc-pVQZ szintú szerkezetek kielégítô pontosságúak a kéntartalmú szpécieszek termokémiai számításaihoz.

\subsubsection{Konformációs analízis}

A $\mathrm{CH}_{2} \mathrm{SO}, \mathrm{HSNO}, \mathrm{HOSO}_{2}, \mathrm{CH}_{2} \mathrm{SH}, \mathrm{S}_{2} \mathrm{COH}$ és $\mathrm{SCSOH}$ molekulák konformációs analíziseinek eredményeit az 5.4. ábra mutatja be. A rotációs gátak, valamint az RRHO közelítéshez számított korrekciók az 5.2. táblázatban olvashatók. A hat molekulára számított anharmonicitási konstansok szimmetrikus mátrixai a Függelék F. 5.-F. 10. táblázataiban láthatók.

A $\mathrm{CH}_{2} \mathrm{SO}$ esetében mindössze egyetlen minimum létezik. A C-S kötés menti rotáció szobahőmérsékleten a $21800 \mathrm{~cm}^{-1}$-es gátmagassággal egyértelmúen tiltott, így az RRHO közelítés megbízhatóan alkalmazható.

A HSNO transz konformere $3.3 \mathrm{~kJ} \mathrm{~mol}^{-1}$-gyel stabilabbnak bizonyult a cisz konformernél. A torziós gátmagasság $3000 \mathrm{~cm}^{-1}$, és a torziós mozgáshoz tartozó rezgési frekvencia körülbelül 400 $\mathrm{cm}^{-1}$. A megfelelő konformerek a harmonikus-oszcillátor közelítésen belül kielégítô pontossággal kezelhetők, mivel $i$ ) a potenciálgörbe a minimumok környékén egyszerú négyzetes függvényekkel közelíthetô és $i i)$ a hetedik gerjesztett rezgési állapot 298 K-en nem elérhetô.

A $\mathrm{HOSO}_{2}$ gyöknek az S-O kötés menti rotáció szerint két megkülönböztethető minimuma létezik, melyek egymással fedésbe nem hozható tárgy-tükörképi viszonyban állnak. A forgatás irányától függően a minimumokat 1267 és $1423 \mathrm{~cm}^{-1}$-es gát választja el egymástól. Mivel a torziós 
mozgáshoz tartozó $301 \mathrm{~cm}^{-1}$-es frekvencia összemérhető a gátmagasságokkal, a mozgást az egydimenziós gátolt-rotátor modellel kezeltük és a megfelelő mennyiségeket az 5.2. táblázat adatai szerint korrigáltuk.

\section{2. táblázat}

A kisfrekvenciájú mozgások kezelése: rotációs gátak, valamint az RRHO közelítéssel kapott ZPE, hőmérsékleti korrekció és entrópia 4.2.2 fejezetben leírtak szerinti korrekciója. ${ }^{\mathrm{a}}$

\begin{tabular}{lcccccc}
\hline \hline molekula & kezelés $^{\mathrm{b}}$ & $\widetilde{\boldsymbol{v}}^{\mathrm{c}}$ & gát $^{\mathrm{d}}$ & $\Delta \mathrm{ZPE}^{\mathrm{e}}$ & $\Delta\left(H_{298}^{\circ}-H_{0}^{\circ}\right)^{\mathrm{e}}$ & $\Delta S_{298}^{\circ}{ }^{\mathrm{e}}$ \\
\hline \hline $\mathrm{CH}_{2} \mathrm{SO}$ & rezgés & 390.0 & 21782 & & & \\
$\mathrm{HSNO}$ & rezgés & 319.8 & 3001 & & & \\
$\mathrm{HOSO}_{2}$ & gátolt rot. & 301.0 & 1267,1423 & -0.3 & 0.2 & 6.7 \\
$\mathrm{CH}_{2} \mathrm{SH}$ & gátolt rot. & 93.6 & 2140 & -0.2 & 0.1 & 2.4 \\
$\mathrm{~S}_{2} \mathrm{COH}$ & rezgés & 567.4 & 3253 & & & \\
$\mathrm{SCSOH}$ & gátolt rot. & 216.5 & 346,976 & -0.1 & 0.2 & 7.6 \\
\hline \hline
\end{tabular}

a A hullámszámok ( $\widetilde{v})$ és gátmagasságok $\mathrm{cm}^{-1}$, a ZPE és termikus korrekció adatok $\mathrm{kJ} \mathrm{mol}^{-1}$, míg az entrópiák $\mathrm{J} \mathrm{K}^{-1} \mathrm{~mol}^{-1}$ egységekben szerepelnek.

b A „rezgés” és „gátolt rot.” jelölések a kérdéses kisfrekvenciájú mozgás kezelésére utalnak. Előbbi harmonikus-oszcillátor, utóbbi gátolt-rotátor kezelést jelent.

c A kisfrekvenciájú mozgáshoz tartozó hullámszám.

d A kisfrekvenciájú mozgáshoz tartozó gátmagasság.

e A harmonikus-oszcillátor és a gátolt-rotátor kezelés eredményei közötti különbség.

A $\mathrm{CH}_{2} \mathrm{SH}$ gyök két nem megkülönböztethetô, planáris szerkezetú minimummal rendelkezik, melyeket egy $2140 \mathrm{~cm}^{-1}$-es gát választ el egymástól, és egy $94 \mathrm{~cm}^{-1}$-es alacsonyfrekvenciájú rezgés asszignálható a kérdéses torzióhoz. A gát ugyan elegendően magas ahhoz, hogy a rotáció szobahőmérsékleten tiltott legyen, a potenciálgörbék alakja nem írható le megfelelő pontossággal a harmonikus közelítésen belül, melyre az anharmonicitási mátrix nagy konstansai egyértelmúen utalnak. Az egydimenziós Schrödinger-egyenlet megoldásából származó korrekciók az 5.2. táblázatban láthatók.

Hasonlóan a $\mathrm{CH}_{2} \mathrm{SH}-h o z$ szintén két egymással ekvivalens planáris minimum létezik az $\mathrm{S}_{2} \mathrm{COH}$ gyökhöz, melyek a C-O kötés menti rotációból állíthatók elő. A rotációs gát, $3250 \mathrm{~cm}^{-1}$, elegendően magas ahhoz, hogy a mozgás szobahőmérsékleten tiltott legyen. Továbbá az anharmonicitási konstansok nem indokolják a speciális kezelést, így a harmonikus-oszcillátor modell használata elegendőnek tekinthető.

Az SCSOH PES-én két, egymással tárgy-tükörképi viszonyban álló minimum található, melyek a CS-OH torziós szög körüli rotáció szerint állnak elő. A forgatás irányától függően a két lokális minimumot egy 346 és egy $976 \mathrm{~cm}^{-1}$ magasságú gát választja el, és a torzióhoz tartozó frekvencia $216 \mathrm{~cm}^{-1}$, ami indokolja a gátolt-rotátor modell alkalmazásának szükségességét. 

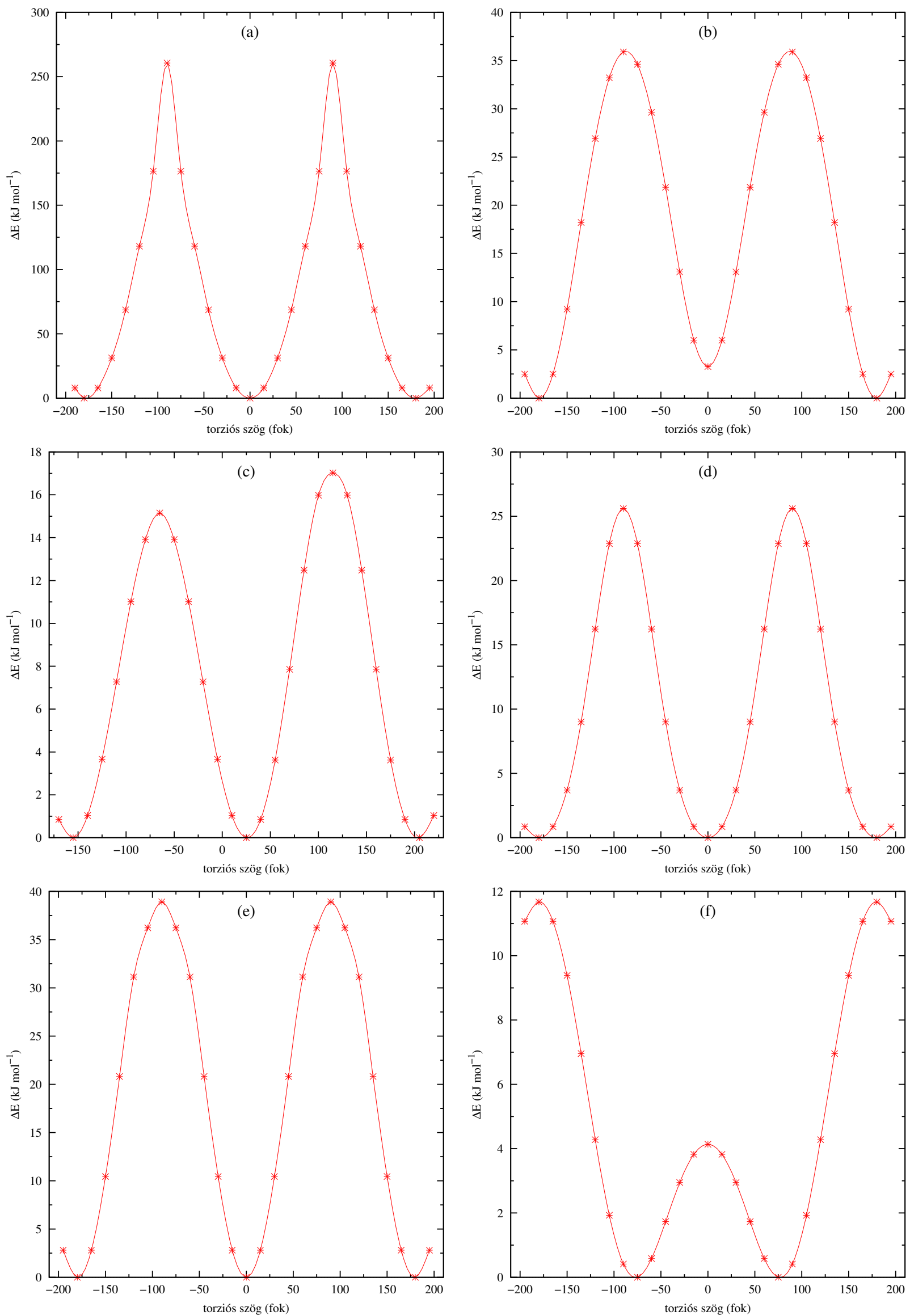

5.4. ábra

CCSD(T)/cc-pVTZ szinten számított potenciális energia görbék (a) $\mathrm{CH}_{2} \mathrm{SO}$, (b) $\mathrm{HSNO}$, (c) $\mathrm{HOSO}_{2}$, (d) $\mathrm{CH}_{2} \mathrm{SH}$, (e) $\mathrm{S}_{2} \mathrm{COH}$, (f) $\mathrm{SCSOH}$ 


\subsection{Rezgési frekvenciák és a zéruspont rezgési energia}

\subsubsection{FPA modell}

A formaldehid teljes anharmonikus zérusponti energiája a CCSD(T)/aug-cc-pCVTZ szintú harmonikus, valamint a variációs magmozgásokból számított anharmonikus tagok összege szerint áll elő: $69.94+(-0.73)=69.21 \mathrm{~kJ} \mathrm{~mol}^{-1}$. Az eredmény jó összhangban van a korábban meghatározott $69.13 \mathrm{~kJ} \mathrm{~mol}^{-1}$-es értékkel, ${ }^{207}$ melyet a 208 referenciában közölt PES alapján számított Bramley és Carrington. Mivel a formaldehid fundamentális rezgési frekvenciáinak reprodukciója valamivel jobb a 208 referencia PES-ének használatával, mint a CCSD(T) szinten számított eredményekkel, ezért a képződési entalpia számításához a $69.13 \mathrm{~kJ} \mathrm{~mol}^{-1}$-es értéket vettük alapul. A teljes ZPE hozzájárulás a $\Delta_{f} H_{0}^{\circ}\left(\mathrm{H}_{2} \mathrm{CO}\right)$ számításának bázisául szolgáló $\mathrm{H}_{2}+\mathrm{CO}=\mathrm{H}_{2} \mathrm{CO}$ reakció esetén + $+30.12 \mathrm{~kJ} \mathrm{~mol}^{-1}$, míg ugyanez a $\mathrm{C}+\mathrm{H}_{2} \mathrm{O}=\mathrm{H}_{2} \mathrm{CO}$ reakciót alapul véve $+13.64 \mathrm{~kJ} \mathrm{~mol}^{-1}$, melyek a $\mathrm{H}_{2}, \mathrm{CO}$ és $\mathrm{H}_{2} \mathrm{O}$ a 4.1.1. fejezetben leírt irodalmi ZPE adatainak felhasználásával számíthatók. Nyilvánvalóan, az atomizációs reakció esetén kizárólag a formaldehid ZPE-jével kell számolnunk. A ZPE adatok bizonytalansága várhatóan nem nagyobb $0.10 \mathrm{~kJ} \mathrm{~mol}^{-1}$-nél.

\subsubsection{HEAT modellek}

A harmonikus rezgési frekvenciák mindkét HEAT modell esetén CCSD(T)/cc-pVQZ számítások eredményeiből származnak. A zéruspont rezgési energiatagok, $\Delta E_{\mathrm{ZPE}}$, a hőmérsékleti korrekciók a harmonikus-oszcillátor közelítésen belül, az entrópiák, valamint az RRHO közelítés korrekcióinak fenti eredményei egyaránt ezeken az adatokon alapulnak. A megfelelő mennyiségek számításához nem használtunk kísérleti, illetve más számítási eredményekből származó értékeket, azaz a referenciaként szereplő elemek, $\mathrm{H}_{2}, \mathrm{O}_{2}, \mathrm{~F}_{2}, \mathrm{Cl}_{2}$ és $\mathrm{N}_{2}$, harmonikus rezgési frekvenciái is a jelen munka eredményei. Az anharmonikus korrekciók hozzájárulásainak kezelése a két modell esetén egymástól eltérố szinteken történt a 4.1.2. és a 4.1.3. fejezetekben leírtaknak megfelelően. A zéruspont rezgési energiák harmonikus és anharmonikus hozzájárulását a végső képződési entalpiákhoz az 5.3. táblázatban tüntettem fel. Látható, hogy a harmonikus hozzájárulások viszonylag nagy értékei mellett az anharmonikus tagok általában jóval kisebbek, egyes esetekben elhanyagolásuk mindössze $0.10 \mathrm{~kJ} \mathrm{~mol}^{-1}$-es hibát jelentene. Általánosan azonban a jellemzően $0.5 \mathrm{~kJ} \mathrm{~mol}^{-1}$-nél nagyobb anharmonikus korrekciók számítása szükséges a szub-kJ mol ${ }^{-1}$-es pontossághoz. 
5.3. táblázat

A zéruspont rezgési energia harmonikus és anharmonikus hozzájárulása a végső $\Delta_{f} H_{0}^{\circ}$ adatokhoz $\mathrm{kJ} \mathrm{mol}^{-1}$ egységekben.

\begin{tabular}{|c|c|c|c|c|c|}
\hline \multicolumn{3}{|c|}{ HEAT-345(Q) } & \multicolumn{3}{|c|}{ HEAT-345+d(Q) } \\
\hline \multirow[b]{2}{*}{ Molekula } & \multicolumn{2}{|c|}{$\Delta E_{\mathrm{ZPE}}$} & \multirow[b]{2}{*}{ Molekula } & \multicolumn{2}{|c|}{$\Delta E_{\mathrm{ZPE}}$} \\
\hline & $\operatorname{harm}^{\mathrm{a}}$ & $\mathrm{anh}^{\mathrm{b}}$ & & $\operatorname{harm}^{\mathrm{a}}$ & $\mathrm{anh}^{\mathrm{b}, \mathrm{c}}$ \\
\hline $\mathrm{F}_{2} \mathrm{CO}$ & 27.15 & -0.12 & HSO & 9.44 & -0.19 \\
\hline $\mathrm{CFClO}$ & 23.27 & -0.11 & HOS & 17.02 & -0.37 \\
\hline FCO & 14.18 & -0.10 & $\mathrm{HOSO}_{2}$ & 31.59 & -0.54 \\
\hline HFCO & 34.45 & -0.41 & transz-HSNO & 14.20 & -0.23 \\
\hline $\mathrm{CHClO}$ & 30.83 & -0.34 & cisz-HSNO & 13.62 & -0.20 \\
\hline cisz-HOCO & 31.92 & -0.63 & $\mathrm{SH}$ & 2.92 & 0.01 \\
\hline transz-HOCO & 32.74 & -0.60 & $\mathrm{CH}_{2} \mathrm{SO}$ & 45.09 & -0.68 \\
\hline \multirow[t]{3}{*}{$\mathrm{NH}_{2} \mathrm{CO}$} & 48.45 & -0.13 & $\mathrm{CH}_{2} \mathrm{SH}$ & 43.19 & 3.25 \\
\hline & & & $\mathrm{SCSOH}$ & 33.75 & -0.60 \\
\hline & & & $\mathrm{S}_{2} \mathrm{COH}$ & 40.27 & -0.64 \\
\hline
\end{tabular}

a A ZPE harmonikus hozzájárulása. $\quad$ b A ZPE anharmonikus hozzájárulása. ${ }^{\mathrm{c}} \mathrm{CCSD}(\mathrm{T}) / \mathrm{cc}-\mathrm{pVTZ}$ szintú eredmények.

\subsection{Nemrelativisztikus energia a CCSD(T) elméleti szintig}

A rendszer nemrelativisztikus hozzájárulását a végsố termokémiai paraméterekhez a HF-SCF és a CCSD(T) korrelációs energiatagok összege szerint definiáltam. Bár szigorú értelemben véve a magasabb rendú korrelációs járulékok, valamint a DBOC is ide tartoznak, előbbiek fontossága miatt mégis külön fejezetekben kerülnek bemutatásra. A számított eredményeket az 5.4-5.8. táblázatok mutatják be, melyekben a kérdéses hozzájárulások a modellnek megfelelő reakcióséma szerint számítva, $\mathrm{kJ} \mathrm{mol}^{-1}$ egységekben szerepelnek. A két HEAT modell esetében a HF-SCF járulék tartalmazza a szén- és kénatomok képződési entalpiáját, a további hozzájárulások számításakor ezeket a paramétereket már nem kell szerepeltetnünk. Továbbá ezekben a táblázatokban szereplő értékek a kJ mol ${ }^{-1}$ egységben vett hozzájárulások a végleges, 0 K-en érvényes képződési entalpiákhoz. Ezzel szemben az FPA-hoz tartozó táblázatok az ezekben feltüntetett 3 reakciósémát jellemző energiaváltozásokat mutatják be.

A HEAT-345(Q), valamint a HEAT-345+d(Q) modelleknél külön foglalkozok a HF-SCF járulék konvergenciájával. Ennek érdekében összehasonlítom a (T,Q,5), valamint a HEAT-345(Q) esetében a $(\mathrm{Q}, 5,6)$ bázisokon alapuló extrapolált eredményeket, ahol a munkám során alkalmazott mindkét extrapolációs formulát figyelembe veszem. Az egyes extrapolációk végeredményekre 
gyakorolt hatását is vizsgálom. Ahogyan az Elméleti összefoglalóban is említettem, a formaldehid származékainak hatszoros- $\zeta$ bázissal számított eredményei, továbbá a HEAT modellek 4.1 formula szerinti extrapolált HF-SCF járulékai összehasonlítási célt szolgálnak, a végső paraméterek származtatása az eredeti protokoll szerint történt.

\subsubsection{FPA modell}

Az FPA modell szerint számított HF-SCF és CCSD(T) hozzájárulások három reakcióséma alapján számított értékei 5.4. táblázatban olvashatók. Az adatok tulajdonképpen a megfelelő reakciót kísérő nemrelativisztikus energiaváltozásnak felelnek meg, a 4.2. fejezetben leírtaknak megfelelően. Látható, hogy a korrelációs járulék az elsô reakció esetén érte el a legnagyobb mértékú konvergenciát. Itt a HF-SCF és a CCSD(T) járulék az aug-cc-pCV6Z bázissal gyakorlatilag teljesen konvergáltnak tekinthetô, az extrapoláció ezeknél a járulékoknál nem feltétlenül szükséges.

Az 5- és 6- $\zeta$ bázissal számított CCSD járulékok közötti különbség szintén az első reakciónál a legkisebb, mindössze $0.11 \mathrm{~kJ} \mathrm{~mol}^{-1}$, míg a $\mathrm{H}_{2} \mathrm{O}+\mathrm{C}$, valamint az atomizációs reakció szerint számított eredmények esetén ez több, mint $1.00 \mathrm{~kJ} \mathrm{~mol}^{-1}$. A két utóbbi séma CCSD(T) eredményei sem tekinthetők teljesen konvergáltnak, bár ezek közül a második reakcióra kapott eredmények kielégítőbbek. A HF-SCF tag mindhárom reakciónál eléri a megfelelő konvergenciát.

5.4. táblázat

A formaldehid nemrelativisztikus focal-point táblázata. Az értékek $\mathrm{kJ} \mathrm{mol}^{-1}$ egységben szerepelnek.

\begin{tabular}{lccc}
\hline \hline \multicolumn{1}{c}{ Bázis } & HF & CCSD & CCSD(T) \\
\hline \hline$H_{2}+\mathrm{CO}=\mathrm{H}_{2} \mathrm{CO}$ & & & \\
aug-cc-pCVDZ & -4.88 & -13.51 & 0.97 \\
aug-cc-pCVTZ & 1.48 & -23.42 & 0.49 \\
aug-cc-pCVQZ & 2.69 & -25.46 & 0.35 \\
aug-cc-pCV5Z & 2.76 & -25.67 & 0.35 \\
aug-cc-pCV6Z & 2.77 & -25.78 & 0.35 \\
\multicolumn{1}{c}{$\infty$} & 2.77 & -25.92 & 0.35 \\
Explicite korrelált & & & \\
aug-cc-pCV5Z & 2.76 & -25.79 & 0.34 \\
aug-cc-pCV6Z & 2.77 & -25.87 & 0.35 \\
R-12 bázis & 2.77 & -25.70 & 0.39 \\
\hline$H_{2} O+C=H_{2} C O$ & & & \\
aug-cc-pCVDZ & -410.66 & -119.52 & -14.94 \\
aug-cc-pCVTZ & -424.74 & -135.50 & -17.87 \\
aug-cc-pCVQZ & -425.78 & -142.36 & -18.61
\end{tabular}

Folytatás a következô oldalon... 
5.4. táblázat - Folytatás az előző oldalról

\begin{tabular}{cccc}
\hline \hline Bázis & HF & CCSD & CCSD(T) \\
\hline \hline aug-cc-pCV5Z & -425.79 & -144.89 & -18.86 \\
aug-cc-pCV6Z & -425.78 & -146.06 & -18.95 \\
$\infty$ & -425.77 & -147.66 & -19.08 \\
Explicite korrelált & & & \\
aug-cc-pCV5Z & -425.79 & -147.56 & -18.76 \\
aug-cc-pCV6Z & -425.78 & -147.54 & -18.89 \\
R-12 bázis & -425.83 & -147.57 & -18.83 \\
\hline 2 H+O+C $=H_{2} C O$ & & \\
aug-cc-pCVDZ & -1057.28 & -383.30 & -24.21 \\
aug-cc-pCVTZ & -1075.96 & -426.46 & -31.97 \\
aug-cc-pCVQZ & -1078.07 & -444.01 & -33.43 \\
aug-cc-pCV5Z & -1078.05 & -449.66 & -33.90 \\
aug-cc-pCV6Z & -1078.05 & -452.00 & -34.08 \\
$\infty$ & -1078.05 & -455.21 & -34.31 \\
Explicite korrelált & & & \\
aug-cc-pCV5Z & -1078.05 & -455.04 & -33.74 \\
aug-cc-pCV6Z & -1078.05 & -455.02 & -33.98 \\
R-12 bázis & -1078.00 & -455.15 & -33.75 \\
\hline \hline
\end{tabular}

Az első reakció explicite korrelált számítási eredményei kiváló egyezést mutatnak a tradicionális módszerek extrapolált és nem extrapolált értékeivel. Megjegyzésre méltó, hogy sokkal kisebb számítási igény mellett az 5- $\zeta$ bázissal CCSD-F12 és CCSD(T)-F12 szinteken végzett számítások hasonló pontosságot eredményeznek, mint a tradicionális 6- $\zeta$ CCSD és CCSD(T) szintek. A

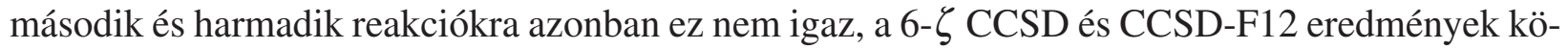
zötti különbségek rendre 1.48 és $3.02 \mathrm{~kJ} \mathrm{~mol}^{-1}$-nek adódtak. Azonban a tradicionális módszerek esetén alkalmazott extrapoláció drasztikusan csillapítja a különbségeket 0.12 és $0.19 \mathrm{~kJ} \mathrm{~mol}^{-1}$-re csökkentve azokat. Mindent összegezve, ahogyan az várható, az első reakció szolgáltatja a legpontosabb nemrelativisztikus hozzájárulásokat, míg a tradicionális módszerek nem megfelelő konvergenciája, valamint az explicite korrelált megfelelőiktől való komoly eltérésük miatt a második és harmadik reakció használata a képződési entalpia számításához nem ajánlott. A nemrelativisztikus tagokhoz tartozó bizonytalanságról a magasabb rendú korrekciók bemutatásánál lesz szó.

\subsubsection{HEAT modellek}

A T, Q, 5 és 6 kardinális számú bázisokkal, az elemi képződési reakció szerint számított HFSCF járulékokat az 5.5. táblázat összegzi. A három- és kétpontos extrapolációs formulákkal kapott 
eredmények az 5.6. táblázatban láthatók.

A szisztematikusan növekvő kardinális számokkal, a négyszeres- $\zeta$ bázistól kezdődően egyértelmú a HF-SCF tag monoton konvergenciája. Ez különösen jól megfigyelhető a HEAT-345(Q) modellnél, ahol elérhetôek voltak a hatszoros- $\zeta$ eredmények is, melyek 5- $\zeta$ eredményektől való eltérése minden esetben csupán néhány század $\mathrm{kJ} \mathrm{mol}^{-1}$. Ugyanakkor látható, hogy a háromszoros- $\zeta$ eredmények minden molekulánál meglepôen távol vannak a konvergált (extrapolált) értékektől, a különbség akár közel $2 \mathrm{~kJ} \mathrm{~mol}^{-1}$ is lehet. A háromszoros- $\zeta$ szint a HSNO kivételével mindenhol kicsit túlbecsüli az $E_{\mathrm{HF}}$ tagot.

Az extrapolált eredmények tekintetében nyilvánvaló, hogy azok az értékek, amelyek a háromszoros- $\zeta$ adatokat is felhasználják, valamivel túlbecsülik a járulékot, bár a Feller-féle (T,Q,5)- és $(\mathrm{Q}, 5,6)$-alapú számok közötti különbségek jóval kisebbek, mint az extrapoláció nél-

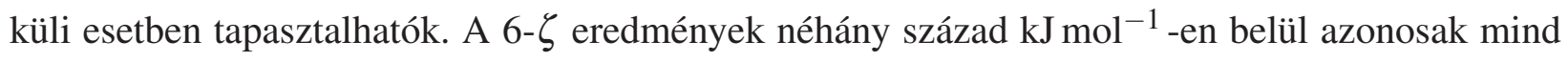
a Feller-féle (Q,5,6)-, mind a Martin-féle (5,6)-alapú tagokkal, továbbá a két formula közötti különbségek szintén elhanyagolható mértékúek. A (Q,5) számításokon alapuló Martin-extrapolációk kiváló egyezést mutatnak az (5,6)-alapúakkal, ami egyértelmúen jelzi, hogy ideálisan az előbbi szint alkalmazása tekinthető elégségesnek az itt tanulmányozott szpécieszek esetén.

5.5. táblázat

A HEAT modellek HF-SCF tagjának hozzájárulása a végső képződési entalpiához $\mathrm{kJ} \mathrm{mol}^{-1}$ egységben.

\begin{tabular}{lrrrr}
\hline & \multicolumn{4}{c}{ Bázis $^{\mathrm{a}}$} \\
\cline { 2 - 5 } Molekula & \multicolumn{1}{c}{$T$} & \multicolumn{1}{c}{$Q$} & \multicolumn{1}{c}{5} & \multicolumn{1}{c}{6} \\
\hline \hline $\mathrm{F}_{2} \mathrm{CO}$ & -485.78 & -487.89 & -487.60 & -487.55 \\
$\mathrm{CFClO}$ & -241.79 & -243.51 & -243.14 & -243.09 \\
$\mathrm{FCO}$ & -47.90 & -49.78 & -49.73 & -49.71 \\
$\mathrm{HFCO}$ & -236.03 & -237.25 & -237.02 & -236.99 \\
$\mathrm{CHClO}$ & 3.57 & 2.82 & 3.10 & 3.14 \\
cisz-HOCO & -3.21 & -3.95 & -3.82 & -3.79 \\
transz-HOCO & -5.38 & -6.23 & -6.10 & -6.07 \\
$\mathrm{NH}_{2} \mathrm{CO}$ & 126.78 & 125.62 & 125.75 & 125.76 \\
\hline $\mathrm{HSO}$ & 107.36 & 105.54 & 104.67 & \\
$\mathrm{HOS}$ & 99.29 & 98.51 & 98.20 & \\
$\mathrm{HOSO}$ & -127.90 & -133.57 & -136.38 & \\
transz-HSNO & 328.63 & 328.74 & 328.83 & \\
cisz-HSNO & 330.96 & 331.08 & 331.16 & \\
$\mathrm{SH}$ & 197.01 & 196.76 & 196.69 & \\
$\mathrm{CH}_{2} \mathrm{SO}$ & 329.11 & 325.23 & 323.72 & \\
Folytatas & & & &
\end{tabular}

Folytatás a következő oldalon... 
5.5. táblázat - Folytatás az előző oldalról

\begin{tabular}{lcccc}
\hline \hline & \multicolumn{4}{c}{ Bázis $^{\mathrm{a}}$} \\
\cline { 2 - 5 } Molekula & $T$ & $Q$ & 5 & 6 \\
\hline \hline $\mathrm{CH}_{2} \mathrm{SH}$ & 380.92 & 378.90 & 378.44 & \\
$\mathrm{SCSOH}$ & 586.31 & 582.20 & 581.27 & \\
$\mathrm{~S}_{2} \mathrm{COH}$ & 471.59 & 468.59 & 468.26 & \\
\hline \hline
\end{tabular}

a A formaldehid származékai esetében az aug-cc-pCVXZ, míg a kéntartalmú molekuláknál az aug-cc-pVX+dZ báziskészletekkel számított eredményeket listáztam.

5.6. táblázat

Extrapolált HEAT HF-SCF energiajárulékok a végső képződési entalpiához kJ mol ${ }^{-1}$ egységben.

\begin{tabular}{|c|c|c|c|c|c|}
\hline \multirow[b]{2}{*}{ Molekula } & \multicolumn{5}{|c|}{ Extrapolációa $^{\mathrm{a}}$} \\
\hline & Feller TQ5 & Feller $Q 56$ & Martin $T Q$ & Martin $Q 5$ & Martin 56 \\
\hline $\mathrm{F}_{2} \mathrm{CO}$ & -487.06 & -487.54 & -488.06 & -487.57 & -487.64 \\
\hline $\mathrm{CFClO}$ & -242.58 & -243.05 & -243.66 & -243.11 & -243.08 \\
\hline FCO & -49.45 & -49.70 & -49.94 & -49.73 & -49.71 \\
\hline HFCO & -236.67 & -236.98 & -237.35 & -237.00 & -236.98 \\
\hline $\mathrm{CHClO}$ & 3.35 & 3.16 & 2.76 & 3.12 & 3.14 \\
\hline cisz-HOCO & -3.67 & -3.79 & -4.01 & -3.81 & -3.79 \\
\hline transz-HOCO & -5.94 & -6.06 & -6.30 & -6.09 & -6.07 \\
\hline $\mathrm{NH}_{2} \mathrm{CO}$ & 125.95 & 125.77 & 125.52 & 125.76 & 125.77 \\
\hline HSO & 104.30 & & 105.39 & 104.60 & \\
\hline HOS & 98.12 & & 98.45 & 98.18 & \\
\hline $\mathrm{HOSO}_{2}$ & -137.83 & & -134.04 & -136.61 & \\
\hline transz-HSNO & 328.93 & & 328.75 & 328.84 & \\
\hline cisz-HSNO & 331.25 & & 331.09 & 331.16 & \\
\hline SH & 196.69 & & 196.74 & 196.68 & \\
\hline $\mathrm{CH}_{2} \mathrm{SO}$ & 323.09 & & 324.91 & 323.59 & \\
\hline $\mathrm{CH}_{2} \mathrm{SH}$ & 378.36 & & 378.73 & 378.40 & \\
\hline $\mathrm{SCSOH}$ & 581.07 & & 581.86 & 581.19 & \\
\hline $\mathrm{S}_{2} \mathrm{COH}$ & 468.34 & & 468.34 & 468.23 & \\
\hline
\end{tabular}

a Az extrapolációs formulák esetében „Feller $X Y Z ”$ jelöli a Feller-féle háromparaméteres extrapolációt, ahol $X Y Z$ az $X, Y, Z$ kardinális számú bázissal számított HF -SCF energiát jelenti. A „Martin $X Y$ ” jelölés az $X, Y$ bázisokkal történő extrapolációt jelenti a Martin-féle kétpontos formula szerint.

A különböző bázisokon és formulákon alapuló extrapolált HF-SCF tagok végeredményekre 
gyakorolt hatását szintén vizsgáltam, ezt az 5.7. táblázat mutatja be. Látható, hogy a legtöbb molekulára az egyes módszerek közötti eltérés akár több tized $\mathrm{kJ} \mathrm{mol}^{-1}$ is lehet, sôt a $\mathrm{HOSO}_{2}$ esetén a 3- $\zeta$ bázison alapuló Feller- és Martin-féle módszerek közel 4 kJ mol ${ }^{-1}$-es különbséget mutatnak. Mindazonáltal a Feller-féle (T,Q,5)-alapú eredmények meglepően jól egyeznek a Martin-féle (Q,5)-alapúakkal, a különbség csak a $\mathrm{HOSO}_{2}$ esetén haladja meg a $0.5 \mathrm{~kJ} \mathrm{~mol}^{-1}$-t. Mivel a Fellerféle (T,Q,5) extrapoláció alkalmazása mellett végzett statisztikai analízisből származó hibahatárok az általam célként kitüzött pontosság eléréséhez megfelelnek, így a végeredményeket ezen a módszeren alapuló HF-SCF tagok felhasználásával számítottam. Így az eredeti HEAT protokoll filozófiája szerinti végeredmények állíthatók elő.

5.7. táblázat

A végső $\Delta_{f} H_{298}^{\circ}$ értékek változása a HF-SCF energiák különböző extrapolációjának hatására $\mathrm{kJ} \mathrm{mol}^{-1}$ egységben a HEAT modellekre.

\begin{tabular}{lrrrrr}
\hline & \multicolumn{5}{c}{ Extrapoláció $^{\mathrm{a}}$} \\
\cline { 2 - 6 } Molekula & Feller TQ5 $^{\mathrm{b}}$ & Feller Q56 & Martin $T Q$ & Martin Q5 & Martin 56 \\
\hline \hline $\mathrm{F}{ }_{2} \mathrm{CO}$ & -603.37 & -603.85 & -604.38 & -603.89 & -603.95 \\
$\mathrm{FCO}$ & -408.35 & -408.81 & -409.42 & -408.88 & -408.85 \\
$\mathrm{HFCO}$ & -177.24 & -177.49 & -177.73 & -177.52 & -177.50 \\
$\mathrm{CHClO}$ & -378.77 & -379.08 & -379.45 & -379.11 & -379.09 \\
cisz-HOCO & -180.82 & -181.01 & -181.41 & -181.05 & -181.03 \\
transz-HOCO & -174.63 & -174.75 & -174.97 & -174.77 & -174.75 \\
$\mathrm{NH}_{2} \mathrm{CO}$ & -181.32 & -181.45 & -181.68 & -181.47 & -181.45 \\
\hline $\mathrm{HSO}$ & -7.21 & -7.40 & -7.64 & -7.40 & -7.40 \\
$\mathrm{HOS}$ & -19.59 & & -18.51 & -19.29 & \\
$\mathrm{HOSO}_{2}$ & -2.36 & & -2.02 & -2.30 & \\
transz-HSNO & -367.53 & & -363.74 & -366.32 & \\
cisz-HSNO & 112.35 & & 112.17 & 112.25 & \\
$\mathrm{SH}_{\mathrm{CH}} \mathrm{SO}$ & 115.81 & & 115.65 & 115.72 & \\
$\mathrm{CH}_{2} \mathrm{SH}$ & 142.82 & & 142.87 & 142.81 & \\
$\mathrm{SCSOH}_{\mathrm{S}}$ & -28.31 & & -26.49 & -27.80 & \\
$\mathrm{~S}_{2} \mathrm{COH}$ & 165.29 & & 165.83 & 165.50 & \\
\hline \hline
\end{tabular}

a A HF-SCF tag extrapolációját jelenti. A jelölések feloldása az 5.6. táblázat lábjegyzetében olvasható.

b A HEAT-345(Q) és a HEAT-345+d(Q) modellel kapott végeredmények.

A CCSD(T) járulékok numerikus eredményeit az 5.8. és 5.9. táblázatokban listáztam, ahol 
utóbbi a HEAT-345 $+d(\mathrm{Q})$ modellben számított $\Delta E_{\text {törzs }}$ tagokat tartalmazza.

5.8. táblázat

A CCSD(T) hozzájárulás a végsô képződési entalpiához kJ mol${ }^{-1}$ egységben.

\begin{tabular}{|c|c|c|c|c|c|c|c|}
\hline \multicolumn{4}{|c|}{ HEAT-345(Q) } & \multicolumn{4}{|c|}{ HEAT-345+d(Q) } \\
\hline \multirow[b]{2}{*}{ Molekula } & \multicolumn{3}{|c|}{ Bázis $^{\mathrm{a}}$} & \multirow[b]{2}{*}{ Molekula } & \multicolumn{3}{|c|}{ Bázis $^{a}$} \\
\hline & $Q$ & 5 & $\infty$ & & $Q$ & 5 & $\infty$ \\
\hline $\mathrm{F}_{2} \mathrm{CO}$ & -139.26 & -144.46 & -149.91 & HSO & -127.47 & -130.99 & -134.69 \\
\hline $\mathrm{CFClO}$ & -185.48 & -189.67 & -194.06 & HOS & -114.03 & -116.61 & -119.33 \\
\hline FCO & -136.73 & -140.62 & -144.71 & $\mathrm{HOSO}_{2}$ & -251.26 & -259.13 & -267.39 \\
\hline $\mathrm{HFCO}$ & -171.47 & -175.83 & -180.39 & transz-HSNO & -223.35 & -226.06 & -228.90 \\
\hline $\mathrm{CHClO}$ & -210.40 & -213.80 & -217.37 & cisz-HSNO & -221.78 & -224.57 & -227.49 \\
\hline cisz-HOCO & -196.32 & -200.79 & -205.49 & SH & -54.20 & -55.36 & -56.57 \\
\hline transz-HOCO & -201.61 & -206.01 & -210.64 & $\mathrm{CH}_{2} \mathrm{SO}$ & -376.96 & -384.35 & -392.11 \\
\hline \multirow[t]{3}{*}{$\mathrm{NH}_{2} \mathrm{CO}$} & -176.42 & -180.34 & -184.45 & $\mathrm{CH}_{2} \mathrm{SH}$ & -247.08 & -251.92 & -256.99 \\
\hline & & & & $\mathrm{SCSOH}$ & -480.43 & -490.16 & -500.37 \\
\hline & & & & $\mathrm{S}_{2} \mathrm{COH}$ & -464.41 & -473.28 & -482.60 \\
\hline
\end{tabular}

a A formaldehid származékok hozzájárulásai AE-CCSD(T)/aug-cc-pCVXZ számítások eredményei, míg a kéntartalmú szpécieszek esetében az FC-CCSD(T)/cc-pV $(X+d) \mathrm{Z}$ értékek olvashatók.

5.9. táblázat

A törzselektronok korrelációs hozzájárulása a végső képződési entalpiához kJ mol ${ }^{-1}$ egységben.

\begin{tabular}{lccclllll}
\hline & \multicolumn{3}{c}{ Bázis $^{\mathrm{a}}$} & & \multicolumn{3}{c}{ Bázis $^{\mathrm{a}}$} \\
\cline { 2 - 3 } \cline { 7 - 9 } Molekula & $\mathrm{T}$ & $\mathrm{Q}$ & $\infty$ & & Molekula & $\mathrm{T}$ & $\mathrm{Q}$ & $\infty$ \\
\hline \hline $\mathrm{HSO}$ & -1.95 & -1.88 & -1.83 & & $\mathrm{SH}$ & -1.08 & -0.97 & -0.89 \\
$\mathrm{HOS}$ & -1.72 & -1.72 & -1.71 & $\mathrm{CH}_{2} \mathrm{SO}$ & -6.48 & -7.07 & -7.51 \\
$\mathrm{HOSO}_{2}$ & -2.77 & -2.96 & -3.10 & $\mathrm{CH}_{2} \mathrm{SH}$ & -6.13 & -6.42 & -6.63 \\
transz-HSNO & -1.62 & -1.09 & -0.70 & & $\mathrm{SCSOH}$ & -8.18 & -8.27 & -8.33 \\
cisz-HSNO & -1.64 & -1.12 & -0.73 & & $\mathrm{~S}_{2} \mathrm{COH}$ & -8.09 & -8.11 & -8.12 \\
\hline \hline
\end{tabular}

a A T és Q oszlopok a cc-pCVTZ és cc-pCVQZ bázisokkal számított eredményeket tartalmazzák. A $\infty$ oszlopban a 4.2. formula szerint extrapolált eredmények láthatók.

A feltüntetett értékek a korrelációs energiák, azaz a HF-SCF járulékot nem tartalmazzák. Az 5.8. táblázatból látható, hogy a kérdéses tag konvergenciája a HF-SCF-hez képest lassabb, a Q és 5 kardinális számú bázisokkal kapott eredmények között átlagosan 2-4 kJ mol-1 -es különbség van, ami jellemzően nem csökken, amennyiben az 5- $\zeta$ és a CBS eredményeket tekintjük. Mindemellett 
a $\mathrm{Q} \rightarrow 5 \rightarrow \mathrm{CBS}$ sorban a konvergencia monotonnak és stabilnak tekinthetô, így várhatóan az extrapolált eredmények jó közelítését adják a korrelációs limitenergiának.

Az 5.9. táblázat adatai szerint, a várakozásoknak megfelelően, a vegyértékelektronokéhoz képest a törzselektronok korrelációjának $\Delta E_{\text {törzs }}$ hozzájárulása a végeredményekhez sokkal kisebb. Ennek ellenére elhanyagolásuk esetén a célul kitûzött pontosság a legtöbb esetben nyilvánvalóan nem teljesülne, így a járulék figyelembevétele mindenképpen szükséges.

A fentieket összegezve az alábbi megállapítások érvényesek a nemrelativisztikus HF-SCF és CCSD(T) hozzájárulásokra:

i) A legpontosabb termokémiai eredmények számításához a háromszoros- $\zeta$ bázison alapuló HF-SCF extrapolációt kerülni kell.

ii) A fenti pontnak némileg ellentmond, hogy a Feller-féle formula szerinti (T,Q,5) extrapoláció a legtöbb molekula esetén jó egyezést mutat a Martin-féle (Q,5) extrapoláción alapuló eredményekkel.

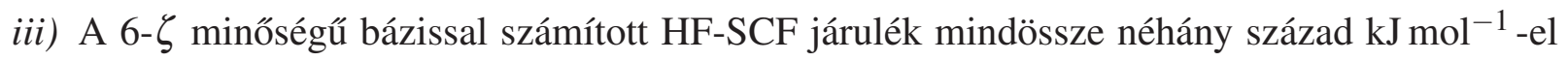
tér el a megfelelő extrapolált értéktől, így a hozzájárulás teljesen konvergáltnak tekinthető. Ilyen esetekben a legmagasabb kardinális számú bázissal kapott eredmény használata az extrapolált helyett nem okoz számottevő hibát, sôt, akár pontosabb végeredményekhez is vezethet. $^{53}$

iv) A CCSD(T) tag konvergenciája a HF-SCF-hez képest jóval lassabb, de a bázisfüggvények számának növekedésével, majd az extrapolációval monotonnak és megfelelő mértékben konvergáltnak tekinthető termokémiai alkalmazásokhoz.

v) A HEAT-345+d(Q) modellben a törzselektronok korrelációjának figyelembevétele az FCCCSD(T) járulék mellett mindenképpen szükséges.

\subsection{Magasabb rendú korrelációs korrekciók}

\subsubsection{FPA modell}

Az FPA modellben számított magasabb rendú korrelációs tagok hozzájárulásai az energiakülönbségekhez az 5.10. táblázatban láthatók. A táblázat utolsó oszlopában az összes nemrelativisztikus tag összegéből elóállított teljes energiakülönbségeket tüntettem fel, melyek az 5.4. és az 5.10. táblázatok megfelelő soraiban szereplő értékek összeadásával kaphatók. Amennyiben a táblázatok egy cellájában már nem szerepel érték - azaz a sorhoz tartozó bázissal az oszlophoz tartozó szinten nem történt számítás -, akkor a kérdéses hozzájárulás legmagasabb szinten meghatározott eredményét vettem. 


\subsection{0. táblázat}

A focal-point modell magasabb rendú korrelációs hozzájárulásai és a teljes nemrelativisztikus reakcióenergia $\mathrm{kJ} \mathrm{mol}^{-1}$ egységben.

\begin{tabular}{|c|c|c|c|c|c|}
\hline Bázis & CCSDT & $\operatorname{CCSDT}(\mathrm{Q})$ & CCSDTQ & CCSDTQ(P) & Teljes $^{\mathrm{a}}$ \\
\hline \multicolumn{6}{|c|}{$\mathrm{H}_{2}+\mathrm{CO}=\mathrm{H}_{2} \mathrm{CO}$} \\
\hline aug-cc-pCVDZ & -0.11 & 0.25 & -0.01 & -0.01 & -17.30 \\
\hline aug-cc-pCVTZ & -0.06 & 0.28 & & & -21.25 \\
\hline aug-cc-pCVQZ & & & & & -22.22 \\
\hline aug-cc-pCV5Z & & & & & -22.36 \\
\hline aug-cc-pCV6Z & & & & & -22.46 \\
\hline$\infty$ & & & & & -22.60 \\
\hline \multicolumn{6}{|c|}{$\mathrm{H}_{2} \mathrm{O}+\mathrm{C}=\mathrm{H}_{2} \mathrm{CO}$} \\
\hline aug-cc-pCVDZ & 0.44 & -1.42 & 0.24 & -0.09 & -545.95 \\
\hline aug-cc-pCVTZ & 1.10 & -1.69 & & & -578.55 \\
\hline aug-cc-pCVQZ & & & & & -587.19 \\
\hline aug-cc-pCV5Z & & & & & -589.98 \\
\hline aug-cc-pCV6Z & & & & & -591.23 \\
\hline$\infty$ & & & & & -592.95 \\
\hline \multicolumn{6}{|c|}{$2 \mathrm{H}+\mathrm{C}+\mathrm{O}=\mathrm{H}_{2} \mathrm{CO}$} \\
\hline aug-cc-pCVDZ & 0.60 & -2.60 & 0.39 & -0.10 & -1466.50 \\
\hline aug-cc-pCVTZ & 1.89 & -2.58 & & & -1534.79 \\
\hline aug-cc-pCVQZ & & & & & -1555.91 \\
\hline aug-cc-pCV5Z & & & & & -1562.01 \\
\hline aug-cc-pCV6Z & & & & & -1564.53 \\
\hline$\infty$ & & & & & -1567.97 \\
\hline
\end{tabular}

a A teljes nemrelativisztikus energia a $\mathrm{HF}, \operatorname{CCSD}, \operatorname{CCSD}(\mathrm{T})$, valamint a jelen táblázatban szereplő tagok összege. Az összegzés részletei a szövegben olvashatók.

A fenti 5.10. táblázatban jól látható, hogy mindhárom reakcióséma esetén a CCSDT(Q) tag szolgáltatja a legnagyobb mértékú hozzájárulást a magasabb rendú korrekciók közül. Mindazonáltal a (Q) tag hozzájárulása a végső nemrelativisztikus energiakülönbségekhez kicsiny, csupán az első reakció esetén haladja meg az 1\%-ot.

A teljes energiák tekintetében elmondhatjuk, hogy a maximális konvergencia az elsô reakció esetén figyelhetô meg. Ebben az esetben ugyanis az 5- és 6- $\zeta$ bázissal számított értékek mindössze 0.10, míg a CBS és 6- $\zeta$ eredmények $0.14 \mathrm{~kJ} \mathrm{~mol}^{-1}$-el térnek el egymástól. Ellenben a második és harmadik reakcióséma alkalmazása esetén ezek a különbségek abszolút értékben rendre 1.25 és $1.72 \mathrm{~kJ} \mathrm{~mol}^{-1}$-nek, valamint 2.52 és $3.44 \mathrm{~kJ} \mathrm{~mol}^{-1}$-nek adódtak. 
A fentiek és az 5.3.1. fejezetben leírtak szerint tehát a formaldehid végleges képződési entalpiája az elsố reakcióra vonatkozó reakcióenergián alapul, melynek értéke $-22.60 \mathrm{~kJ} \mathrm{~mol}^{-1}$, és az ehhez tartozó bizonytalanság várhatóan nem nagyobb, mint $\pm 0.20 \mathrm{~kJ} \mathrm{~mol}^{-1}$.

\subsubsection{HEAT modellek}

A HEAT-345(Q) és a HEAT-345+d(Q) modellek magasabb rendú korrelációs hozzájárulásait a végső képződési entalpiákhoz az 5.11. táblázat mutatja be.

A HEAT-345(Q) esetén a CCSDT tag konvergenciája a $\mathrm{T} \rightarrow \mathrm{Q} \rightarrow$ CBS sorban stabilnak és monotonnak tekinthetô, és a kétpontos extrapolációs formula minden esetben elfogadható eredményeket szolgáltat. A CCSD(T) eredményekkel összehasonlítva mindkét modellnél látható, hogy a CCSDT és CCSDT(Q) járulékok jóval kisebbek, azaz ahogyan az várható, a CCSD(T) járulék tartalmazza a korrelációs hatások legnagyobb részét.

A HEAT-345(Q) modellhez tartozó CCSDT(Q) eredmények jól szemléltetik a módszer Elméleti összefoglalóban említett bázisfüggését az F- és Cl-tartalmú rendszerek esetén. A kérdéses atomokat nem tartalmazó molekulákra a $\Delta E_{\mathrm{CCSDT}(\mathrm{Q})}$ tag értéke a kétszeres- és háromszoros- $\zeta$ bázisokkal számítva szinte azonosnak mondható, míg egyéb esetekben a különbség több tized $\mathrm{kJ} \mathrm{mol}^{-1}$ is lehet.

5.11. táblázat

A HEAT-345(Q) és a HEAT-345+d(Q) modellek magasabb rendú korrelációs hozzájárulásai a végső képződési entalpiákhoz $\mathrm{kJ} \mathrm{mol}^{-1}$ egységekben.

\begin{tabular}{|c|c|c|c|c|c|c|c|c|}
\hline \multicolumn{6}{|c|}{ HEAT-345(Q) ${ }^{\mathrm{a}}$} & \multicolumn{3}{|c|}{ HEAT-345+d $(\mathrm{Q})^{\mathrm{b}}$} \\
\hline \multirow[b]{2}{*}{ Molekula } & \multicolumn{3}{|c|}{ CCSDT } & \multicolumn{2}{|c|}{$\operatorname{CCSDT}(Q)$} & \multirow[b]{2}{*}{ Molekula } & \multirow{2}{*}{$\frac{\mathrm{CCSDT}}{T+d}$} & \multirow{2}{*}{$\frac{\operatorname{CCSDT}(\mathrm{Q})}{T+d}$} \\
\hline & $T$ & $Q$ & $\infty$ & $D$ & $T$ & & & \\
\hline $\mathrm{F}_{2} \mathrm{CO}$ & 1.37 & 1.76 & 2.04 & 1.98 & 2.37 & HSO & -0.38 & -0.73 \\
\hline $\mathrm{CFClO}$ & 1.60 & 2.01 & 2.31 & 0.69 & 0.78 & HOS & 0.09 & 0.05 \\
\hline FCO & 0.15 & 0.52 & 0.78 & 0.44 & 0.50 & $\mathrm{HOSO}_{2}$ & $1.61^{\mathrm{d}}$ & $0.69^{d}$ \\
\hline $\mathrm{HFCO}$ & 0.93 & 1.30 & 1.57 & 0.80 & 1.01 & $t-\mathrm{HSNO}^{\mathrm{c}}$ & -0.77 & -3.88 \\
\hline $\mathrm{CHClO}$ & 1.00 & 1.37 & 1.64 & -0.47 & -0.61 & $c-\mathrm{HSNO}^{\mathrm{c}}$ & -0.62 & -3.65 \\
\hline$c-\mathrm{HOCO}^{\mathrm{c}}$ & 0.46 & 0.87 & 1.18 & 0.45 & 0.47 & $\mathrm{SH}$ & -0.09 & -0.23 \\
\hline$t-\mathrm{HOCO}^{\mathrm{c}}$ & 0.41 & 0.84 & 1.15 & 0.39 & 0.40 & $\mathrm{CH}_{2} \mathrm{SO}$ & 2.06 & -3.99 \\
\hline \multirow[t]{3}{*}{$\mathrm{NH}_{2} \mathrm{CO}$} & -0.15 & 0.18 & 0.41 & 0.64 & 0.69 & $\mathrm{CH}_{2} \mathrm{SH}$ & 0.52 & -1.50 \\
\hline & & & & & & SCSOH & $2.38^{\mathrm{e}}$ & $-4.93^{\mathrm{d}}$ \\
\hline & & & & & & $\mathrm{S}_{2} \mathrm{COH}$ & $0.96^{\mathrm{d}}$ & $-6.06^{\mathrm{d}}$ \\
\hline
\end{tabular}

a FC számítások a cc-pVTZ és cc-pVQZ bázisokkal. Az extrapoláció a kétparaméteres formula szerint történt.

${ }^{\mathrm{b}} \mathrm{FC}$ számítások a cc-pV(T+d)Z bázissal. $\quad{ }^{\mathrm{c}} c=$ cisz és $t=$ transz

d MP2 FNO módszerrel számított érték. (5.12. táblázat) e Tradicionális CC módszerrel számított eredmény. 
A $\mathrm{HOSO}_{2}, \mathrm{~S}_{2} \mathrm{COH}$ és SCSOH gyökök CCSDT és CCSDT(Q) hozzájárulásainak MP2 FNO módszerrel történő közelítését az 5.12. táblázat mutatja be. A CCSDT és a CCSDT(Q) járulékokat a különböző $\varepsilon$ értékek alkalmazásával számított CCSD(T), CCSDT és CCSDT(Q) teljes energiákból állíthatjuk elő az alábbi módon:

$$
\begin{aligned}
\Delta E_{\mathrm{CCSDT}} & =E_{\mathrm{CCSDT}}-E_{\mathrm{CCSD}(\mathrm{T})} \\
\Delta E_{\mathrm{CCSDT}(\mathrm{Q})} & =E_{\mathrm{CCSDT}(\mathrm{Q})}-E_{\mathrm{CCSDT}},
\end{aligned}
$$

melyekből ugyanúgy, mint a többi járuléknál, az elemi képződési reakciók bázisán számíthatók a képződési entalpiákhoz történő hozzájárulások $\mathrm{kJ} \mathrm{mol}^{-1}$-ben vett értékei. A 4.9. egyenletben szereplő $\Delta E_{\mathrm{CCSDT}(\mathrm{Q})}$ tag a táblázat CCSDT és CCSDT(Q) oszlopaiban szereplő értékek összege szerint adható meg.

A $\mathrm{HOSO}_{2}$ esetén az $\varepsilon=0.975$-höz tartozó eredményeket vettem alapul, míg az ehhez tartozó hibát az $\varepsilon=0.95$ és 0.975 -ös értékekből történő lineáris extrapolációval meghatározott hozzájárulások szerint becsültem. Azaz a gyök képződési entalpiájához tartozó hiba a 4.3. fejezetben bevezetett atomi járulékokból, illetve a lenti táblázat megfelelő soraiból egyszerú összegzéssel állítható elő: $0.4+0.4+1.5+0.4+0.4+0.4+0.9=4.4 \mathrm{~kJ} \mathrm{~mol}^{-1}$.

Az $\mathrm{S}_{2} \mathrm{COH}$ CCSDT és CCSDT(Q) járulékait a 0.995-ös $\varepsilon$-hoz tartozó értékek szerint adtam meg, és az extrapoláció az $\varepsilon=0.9875,0.99$ és 0.995-höz tartozó eredmények alapján történt. A gyök $\Delta_{f} H_{0}^{\circ}$ és $\Delta_{f} H_{298}^{\circ}$ adatához tartozó végleges bizonytalanság a $\mathrm{HOSO}_{2}$-nél leírtaknak megfelelöen $4.6 \mathrm{~kJ} \mathrm{~mol}^{-1}$-nek adódott.

\subsection{2. táblázat}

Az MP2 FNO módszerrel cc-pVTZ bázissal számított CCSDT és CCSDT(Q) hozzájárulások a

\begin{tabular}{|c|c|c|c|c|c|c|c|c|}
\hline \multicolumn{3}{|c|}{$\mathrm{HOSO}_{2}$} & \multicolumn{3}{|c|}{$\mathrm{S}_{2} \mathrm{COH}$} & \multicolumn{3}{|c|}{$\mathrm{SCSOH}$} \\
\hline$\varepsilon$ & CCSDT & $\operatorname{CCSDT}(\mathrm{Q})$ & $\varepsilon$ & CCSDT & CCSDT(Q) & $\varepsilon$ & CCSDT & $\operatorname{CCSDT}(\mathrm{Q})$ \\
\hline 0.900 & 1.45 & -0.25 & 0.9500 & 1.67 & -4.65 & 0.9250 & 3.10 & -2.90 \\
\hline 0.925 & 1.19 & -0.45 & 0.9750 & 1.10 & -5.26 & 0.9500 & 2.68 & -3.33 \\
\hline 0.950 & 1.20 & -0.17 & 0.9875 & 1.04 & -5.57 & 0.9750 & 2.29 & -4.93 \\
\hline \multirow[t]{2}{*}{0.975} & 1.61 & 0.69 & 0.9900 & 1.03 & -5.70 & 0.9875 & 2.31 & -5.25 \\
\hline & & & 0.9950 & 0.96 & -6.06 & & & \\
\hline $1.000^{\mathrm{a}}$ & 2.03 & 1.55 & $1.0000^{\mathrm{a}}$ & 0.90 & -6.39 & $1.0000^{\mathrm{a}}$ & 1.88 & -5.75 \\
\hline hiba & 0.41 & 0.86 & & 0.06 & 0.33 & & 0.41 & 0.82 \\
\hline
\end{tabular}
végső képződési entalpiához $\mathrm{kJ} \mathrm{mol}^{-1}$ egységben.

a A különböző $\varepsilon$-okhoz tartozó eredményekből extrapolált értékek.

Az SCSOH esetén a CCSDT járulékot a képződési entalpiához, $2.38 \mathrm{~kJ} \mathrm{~mol}^{-1}$, a tradicionális CCSDT módszerrel számítottam. Az érték jól egyezik a legnagyobb $\varepsilon$-hoz tartozó MP2 FNO eredménnyel, az eltérés mindössze $0.07 \mathrm{~kJ} \mathrm{~mol}^{-1}$, azonban a küszöbérték növekedésével az eredmények divergenciát mutatnak. A négy különböző $\varepsilon$-hoz tartozó CCSDT és CCSDT(Q) hozzájá- 
rulások az $\varepsilon=0.925,0.950$ és 0.975 értékek mellett tekinthetôk lineárisnak. Ezért a CCSDT(Q) járulékot az $\varepsilon=0.975$-höz tartozó eredménnyel közelítettem, melynek hibáját a 0.925, 0.950 és 0.975 küszöbértékek szerinti extrapolációval adtam meg. A képződési entalpiák bizonytalansága, $5.0 \mathrm{~kJ} \mathrm{~mol}^{-1}$, a protokoll atomi járulékaiból, valamint a CCSDT(Q) MP2 FNO módszer szerinti közelítésének hibájából, 0.8 kJ mol ${ }^{-1}$, adódik össze.

A fentiek szerint tehát a végeredmények számításához az 5.11. táblázat negyedik és ötödik, valamint nyolcadik és kilencedik oszlopában szereplő adatokat használtam fel.

\subsection{További korrekciók}

\subsubsection{Skaláris relativisztikus hatások}

\subsubsection{FPA modell}

A CCSD(T)/aug-cc-pCVTZ és CCSD(T)/aug-cc-pCVQZ szinten számított MVD1 és DKH korrekciók, valamint ezek átlagolásával származtatott eredmények hozzájárulásai a végső $\Delta_{f} H_{0}^{\circ}\left(\mathrm{H}_{2} \mathrm{CO}\right)$-hoz az alábbi táblázatban láthatók. A táblázatban szereplő adatok tartalmazzák a C- és O-atomok spin-pálya hozzájárulásait is a második és harmadik reakció esetében.

\begin{tabular}{lcccccccc}
\hline \hline & \multicolumn{3}{c}{ aug-cc-pCVTZ } & & \multicolumn{3}{c}{ aug-cc-pCVQZ } \\
\cline { 2 - 3 } \cline { 8 - 9 } Reakció & DKH & MVD1 & átlag & & DKH & MVD1 & átlag \\
\hline \hline $\mathrm{H}_{2}+\mathrm{CO}=\mathrm{H}_{2} \mathrm{CO}$ & 0.72 & 0.74 & 0.73 & & 0.72 & 0.74 & 0.73 \\
$\mathrm{H}_{2} \mathrm{O}+\mathrm{C}=\mathrm{H}_{2} \mathrm{CO}$ & 0.64 & 0.66 & 0.65 & & 0.64 & 0.65 & 0.64 \\
$2 \mathrm{H}+\mathrm{C}+\mathrm{O}=\mathrm{H}_{2} \mathrm{CO}$ & 2.66 & 2.73 & 2.69 & & 2.68 & 2.72 & 2.70 \\
\hline \hline
\end{tabular}

Látható, hogy a két bázissal számított skaláris relativisztikus korrekciók gyakorlatilag megegyeznek, csak a harmadik reakció esetén figyelhető meg az adatok bázistól való elhanyagolhatóan kicsi függése, ami az átlagolásnál eltúnik. Továbbá a negyedrendû DKH és MVD1 értékek szintén jó egyezést mutatnak, a legnagyobb különbség ezek között az atomizációs reakciónál tapasztalható. Az eredmények szintén az elsố reakció használatát támogatják a képződési entalpia számításához.

\subsubsection{HEAT modellek}

Az egy- és kételektron Darwin-tagból, valamint a tömeg-sebesség korrekcióból előálló skaláris relativisztikus effektusok hozzájárulásai a végeredményekhez az 5.15. táblázatban láthatók. Az értékek tartalmazzák az atomi spin-pálya csatolásokat is. 
5.15. táblázat

A skaláris relativisztikus korrekciók hozzájárulásai a HEAT modellek $\Delta_{f} H_{0}^{\circ}$ adataihoz $\mathrm{kJ} \mathrm{mol}^{-1}$ egységben.

\begin{tabular}{|c|c|c|c|}
\hline \multicolumn{2}{|c|}{ HEAT-345(Q) } & \multicolumn{2}{|c|}{ HEAT-345+d(Q) } \\
\hline Molekula & MVD2 & Molekula & MVD2 \\
\hline $\mathrm{F}_{2} \mathrm{CO}$ & 2.71 & HSO & 4.30 \\
\hline $\mathrm{CFClO}$ & 2.28 & HOS & 3.67 \\
\hline $\mathrm{FCO}$ & 1.66 & $\mathrm{HOSO}_{2}$ & 7.99 \\
\hline $\mathrm{HFCO}$ & 1.97 & $t$-HSNO & 3.67 \\
\hline $\mathrm{CHClO}$ & 1.58 & $c$-HSNO & 3.62 \\
\hline$c$-HOCO & 1.84 & SH & 0.91 \\
\hline$t$-HOCO & 1.82 & $\mathrm{CH}_{2} \mathrm{SO}$ & 5.87 \\
\hline \multirow[t]{3}{*}{$\mathrm{NH}_{2} \mathrm{CO}$} & 2.25 & $\mathrm{CH}_{2} \mathrm{SH}$ & 5.30 \\
\hline & & $\mathrm{SCSOH}$ & 8.72 \\
\hline & & $\mathrm{S}_{2} \mathrm{COH}$ & 8.17 \\
\hline
\end{tabular}

Mind az FPA, mind a HEAT modellek esetén a hozzájárulások növelik a végeredményeket. Látható, hogy néhány molekula esetén, a relativisztikus korrekció értéke az $5 \mathrm{~kJ} \mathrm{~mol}^{-1}$-es értéket is meghaladja, így a célul kitűzött pontossághoz a tagok figyelembevétele mindenképpen szükséges.

\subsubsection{Diagonális Born-Oppenheimer korrekció}

\subsubsection{FPA modell}

Az FPA modell esetén a legkisebb járulékot szolgáltató DBOC tag értéke a három reakcióra az alábbiak szerint alakul:

$\mathrm{H}_{2}+\mathrm{CO}=\mathrm{H}_{2} \mathrm{CO}: 0.14 \mathrm{~kJ} \mathrm{~mol}^{-1}$

$\mathrm{H}_{2} \mathrm{O}+\mathrm{C}=\mathrm{H}_{2} \mathrm{CO}: 0.42 \mathrm{~kJ} \mathrm{~mol}^{-1}$

$2 \mathrm{H}+\mathrm{C}+\mathrm{O}=\mathrm{H}_{2} \mathrm{CO}: 0.04 \mathrm{~kJ} \mathrm{~mol}^{-1}$,

ahol a második reakcióra vonatkozó adat HF-SCF/aug-cc-pVTZ szintû. Az elsô és harmadik reakció járulékai a HF-SCF és az FC-CISD/aug-cc-pVDZ szintű tagok összegeibôl származnak. A $\mathrm{H}_{2}+\mathrm{CO}$ reakcióra előbbi $0.18 \mathrm{~kJ} \mathrm{~mol}^{-1}$, ehhez adódik hozzá a kicsiny $-0.04 \mathrm{~kJ} \mathrm{~mol}^{-1}$ értékú korrelációs járulék. Az atomizációs reakció megfelelő hozzájárulásai rendre -0.11 és $+0.15 \mathrm{~kJ} \mathrm{~mol}^{-1}$, ahol a nagy különbség nyilvánvalóan bizonytalanabbá teszi az atomizációs sémán alapuló $\Delta_{f} H_{0}^{\circ}$ számítását. A DBOC eredmények tehát szintén az elsô reakció, mint bázis használatát támogatják. A DBOC taghoz tartozó hiba az első reakció esetén jó közelítéssel elhanyagolhatónak tekinthető. 


\subsubsection{HEAT modellek}

A HEAT modellek esetén a DBOC hozzájárulás szintén a legkisebb mértékú, értéke az 5.16. táblázatban látható. A $\Delta E_{\mathrm{DBOC}}$ tag az egyetlen $\mathrm{NH}_{2} \mathrm{CO}$ kivételével (-0.34 $\left.\mathrm{kJ} \mathrm{mol}^{-1}\right)$ abszolút értékben sehol nem haladja meg a $0.3 \mathrm{~kJ} \mathrm{~mol}^{-1}$-es értéket. Ez azt jelenti, hogy amennyiben a célul kitúzött pontosság az $\pm 1.00 \mathrm{~kJ} \mathrm{~mol}^{-1}$-es értéknél nagyobb, akkor a DBOC számítások kivitelezése - ami kevés kivételtől eltekintve egyébként nem ütközik technikai akadályokba - nem feltétlenül szükséges.

5.16. táblázat

A DBOC korrekciók hozzájárulásai a HEAT modellek $\Delta_{f} H_{0}^{\circ}$ adataihoz kJ mol${ }^{-1}$ egységben.

\begin{tabular}{lcllc}
\hline \hline \multicolumn{2}{c}{ HEAT-345(Q) } & & \multicolumn{2}{c}{ HEAT-345+d(Q) } \\
\cline { 1 - 1 } \cline { 1 - 1 } Molekula & DBOC & & Molekula & DBOC \\
\hline \hline $\mathrm{F}_{2} \mathrm{CO}$ & -0.17 & & $\mathrm{HSO}$ & 0.18 \\
$\mathrm{CFClO}$ & -0.14 & & $\mathrm{HOS}$ & 0.11 \\
$\mathrm{FCO}$ & -0.05 & & $\mathrm{HOSO}_{2}$ & -0.23 \\
$\mathrm{HFCO}$ & -0.09 & & $t$ - $\mathrm{HSNO}$ & 0.02 \\
$\mathrm{CHClO}$ & -0.04 & & $c-\mathrm{HSNO}$ & 0.02 \\
$c-\mathrm{HOCO}$ & -0.23 & & $\mathrm{SH}$ & 0.07 \\
$t$ - $\mathrm{HOCO}$ & -0.24 & & $\mathrm{CH}_{2} \mathrm{SO}$ & -0.12 \\
$\mathrm{NH}{ }_{2} \mathrm{CO}$ & -0.34 & & $\mathrm{CH}_{2} \mathrm{SH}$ & -0.05 \\
& & & $\mathrm{SCSOH}_{2}$ & -0.17 \\
& & & $\mathrm{~S}_{2} \mathrm{COH}$ & -0.17 \\
\hline \hline
\end{tabular}




\subsection{Végeredmények 0 és 298.15 K-en}

\subsubsection{FPA modell}

Az FPA modell keretein belül figyelembe vett három reakció bázisán végzett számítások az alábbi táblázat szerint foglalhatók össze:

\subsection{7. táblázat}

Az FPA modell három reakciójának bázisán számított hozzájárulások és a végső képződési entalpiák $0 \mathrm{~K}$-en. Minden mennyiség kJ mol ${ }^{-1}$ egységben szerepel.

\begin{tabular}{lrcccc}
\hline \hline reakció & $\mathrm{CBS} \mathrm{NR}^{\mathrm{a}}$ & rel $^{\mathrm{b}}$ & $\mathrm{DBOC}$ & $\mathrm{ZPE}$ & $\Delta_{f} H_{0}^{\circ}\left(\mathrm{H}_{2} \mathrm{CO}\right)$ \\
\hline \hline $\mathrm{H}_{2}+\mathrm{CO}=\mathrm{H}_{2} \mathrm{CO}$ & -22.60 & 0.73 & 0.14 & 30.12 & -105.42 \\
$\mathrm{H}_{2} \mathrm{O}+\mathrm{C}=\mathrm{H}_{2} \mathrm{CO}$ & -592.95 & 0.65 & $0.42^{\mathrm{c}}$ & 13.63 & -105.58 \\
$2 \mathrm{H}+\mathrm{C}+\mathrm{O}=\mathrm{H}_{2} \mathrm{CO}$ & -1567.97 & 2.69 & 0.04 & 69.13 & -105.63 \\
\hline \hline
\end{tabular}

a Nemrelativisztikus teljes energia: A végtelen bázisra extrapolált HF-SCF, CCSD és CCSD(T), valamint a magasabb rendú korrelációs tagok összege.

b A skaláris relativisztikus korrekciók hozzájárulása.

c HF-SCF szinten számított adat.

A fenti három $\Delta_{f} H_{0}^{\circ}$ érték közül, az előző fejezetekben leírt okok miatt az első reakcióhoz tartozó -105.42 $\mathrm{kJ} \mathrm{mol}^{-1}$-es érték a legpontosabb, ezt fogadjuk el a formaldehid végső képződési entalpiájának. Az érték a $\mathrm{H}_{2}+\mathrm{CO}=\mathrm{H}_{2} \mathrm{CO}$ folyamat számított reakcióhőjéból, $\Delta_{r} H_{0}^{\circ}=+8.39$ $\mathrm{kJ} \mathrm{mol}^{-1}$, származtatható $\Delta_{f} H_{0}^{\circ}(\mathrm{CO})$ adat ismeretében. Az egyes hozzájárulások bizonytalanságait összegezve egy $0.40 \mathrm{~kJ} \mathrm{~mol}^{-1}$-es hibahatár adható meg a $0 \mathrm{~K}$-es végeredményhez, mely tehát $\Delta_{f} H_{0}^{\circ}\left(\mathrm{H}_{2} \mathrm{CO}\right)=-105.42 \pm 0.40 \mathrm{~kJ} \mathrm{~mol}^{-1}$. A 4.2. fejezetben leírtak szerin elvégzett hőmérsékleti korrekciókkal a $298.15 \mathrm{~K}$-en érvényes végeredmény: $\Delta_{f} H_{298}^{\circ}\left(\mathrm{H}_{2} \mathrm{CO}\right)=-109.23 \pm 0.40 \mathrm{~kJ} \mathrm{~mol}^{-1}$.

\subsubsection{HEAT modellek}

A HEAT-345(Q) és a HEAT-345+d(Q) modellek végeredményei - hőmérsékleti korrekciók, képződési entalpiák 0 és 298.15 K-en, valamint képződési entrópiák - az 5.18. táblázatban láthatók összefoglalva. Az értékek rövid diszkussziója és korábbi irodalmi adatokkal történő összehasonlítása az 5.7. fejezetben olvasható. A lenti táblázatban szereplő képződési entalpia értékek az előző fejezetekben bemutatott megfelelő hozzájárulások összegzésével kaphatók, míg a hőmérsékleti korrekciók, valamint a standard képződési entrópiák a 4.2. fejezetben bemutatott összefüggések szerint állíthatók elő a számítási eredményekből. 


\subsection{8. táblázat}

A számítási eredmények összegzése : hőmérsékleti korrekciók, képződési entalpiák ( $\mathrm{kJ} \mathrm{mol}^{-1}$ egységben) 0 és $298.15 \mathrm{~K}$ hômérsékleten és standard moláris entrópiák ( $\mathrm{J} \mathrm{K}^{-1} \mathrm{~mol}^{-1}$ egységben) $298.15 \mathrm{~K}$-en

\begin{tabular}{|c|c|c|c|c|}
\hline \multirow[b]{2}{*}{ Molekula } & \multirow[b]{2}{*}{$H_{298}^{\circ}-H_{0}^{\circ}$} & \multicolumn{2}{|c|}{ Képződési entalpia } & \multirow[b]{2}{*}{$S_{298}^{\circ}$} \\
\hline & & $\Delta_{f} H_{0}^{\circ}$ & $\Delta_{f} H_{298}^{\circ}$ & \\
\hline $\mathrm{CF}_{2} \mathrm{O}$ & 11.1 & $-603.4 \pm 1.2$ & $-606.5 \pm 1.2$ & $258.6 \pm 1.5$ \\
\hline $\mathrm{FCO}$ & 10.4 & $-177.2 \pm 0.9$ & $-176.7 \pm 0.9$ & $248.8 \pm 1.5$ \\
\hline HFCO & 10.4 & $-378.8 \pm 1.2$ & $-382.5 \pm 1.2$ & $246.5 \pm 1.5$ \\
\hline $\mathrm{HClCO}$ & 11.0 & $-180.8 \pm 1.7$ & $-184.2 \pm 1.7$ & $258.7 \pm 1.5$ \\
\hline $\mathrm{FClCO}$ & 11.9 & $-408.4 \pm 1.7$ & $-410.9 \pm 1.7$ & $276.4 \pm 1.5$ \\
\hline cisz-HOCO & 10.9 & $-174.6 \pm 1.2$ & $-177.8 \pm 1.2$ & $251.7 \pm 1.5$ \\
\hline transz-HOCO & 10.9 & $-181.3 \pm 1.2$ & $-184.5 \pm 1.2$ & $251.4 \pm 1.5$ \\
\hline $\mathrm{NH}_{2} \mathrm{CO}$ & 12.5 & $-7.2 \pm 1.5$ & $-13.1 \pm 1.5$ & $256.5 \pm 1.5$ \\
\hline $\mathrm{HSO}$ & 10.1 & $-19.6 \pm 2.3$ & $-22.6 \pm 2.3$ & $241.4 \pm 1.5$ \\
\hline HOS & 10.1 & $-2.4 \pm 2.3$ & $-5.3 \pm 2.3$ & $240.0 \pm 1.5$ \\
\hline $\mathrm{HOSO}_{2}$ & 13.6 & $-367.5 \pm 4.4$ & $-375.7 \pm 4.4$ & $294.1 \pm 1.5$ \\
\hline transz-HSNO & 12.4 & $112.4 \pm 2.7$ & $107.3 \pm 2.7$ & $266.4 \pm 1.5$ \\
\hline cisz-HSNO & 12.4 & $115.8 \pm 2.7$ & $110.7 \pm 2.7$ & $266.1 \pm 1.5$ \\
\hline $\mathrm{SH}$ & 9.3 & $142.8 \pm 1.9$ & $143.4 \pm 1.9$ & $195.4 \pm 1.5$ \\
\hline $\mathrm{CH}_{2} \mathrm{SO}$ & 11.7 & $-28.3 \pm 3.1$ & $-35.1 \pm 3.1$ & $261.4 \pm 1.5$ \\
\hline $\mathrm{CH}_{2} \mathrm{SH}$ & 13.4 & $165.3 \pm 3.1$ & $160.2 \pm 3.1$ & $270.0 \pm 1.5$ \\
\hline $\mathrm{SCSOH}$ & 16.0 & $111.4 \pm 5.0$ & $108.9 \pm 5.0$ & $321.8 \pm 1.5$ \\
\hline $\mathrm{S}_{2} \mathrm{COH}$ & 13.5 & $20.1 \pm 4.6$ & $15.1 \pm 4.6$ & $296.9 \pm 1.5$ \\
\hline
\end{tabular}

A formaldehid és annak több itt vizsgált származéka, valamint egyes kéntartalmú molekulák esetén is a jelen munkában számított képződési entalpia és/vagy entrópia értékeket javasoljuk későbbi felhasználásra nagy pontosságú termokémiai számításokhoz. Az irodalmi adatok összehasonlításával foglalkozó 5.7. fejezet végén, az 5.36. táblázatban összegyújtöttem a munkám során tárgyalt összes szpécieszre elérhető legpontosabb képződési entalpia- és entrópiaadatokat, melyek közül a dőlten szedettek a saját számítási eredmények.

\subsubsection{A kéntartalmú vegyületek tesztmodelljei}

Az Elméleti összefoglaló 4.2.1. fejezetében említettem, hogy a HEAT-345+d(Q) modell kidolgozásakor a végsố protokoll összeállítása során vizsgált tesztmodellek eredményei jelentôsen különböztek a referenciaadatoktól, amennyiben a kénatom NIST-JANAF adatbázisból származó képző- 
déshőjét használtuk. Az 5.19. táblázat, valamint az 5.5. ábra ezeket az eredményeket mutatja be numerikusan és grafikusan. A táblázatokban a tesztkészlet $\left(\mathrm{S}_{2}, \mathrm{H}_{2} \mathrm{~S}, \mathrm{SO}\right.$ és $\left.\mathrm{SO}_{2}\right)$ megfelelő modellekkel számított képződési entalpiái olvashatók kJ mol ${ }^{-1}$ egységben 0, valamint 298.15 K hőmérsékleten. Minden egyes modell-hômérséklet párhoz két érték tartozik: a táblázatok bal oldali oszlopaiban a kénatom NIST-JANAF, míg a jobb oldali oszlopokban a jelen munkában bevezetett képződéshőjét használtam a számításokhoz. A két különböző adatot rendre a $\Delta_{f} H_{T}^{\circ}(\mathrm{S})(1)$ és $\Delta_{f} H_{T}^{\circ}(\mathrm{S})(2)$ jelöli a táblázatok fejlécében.

A modelleket, valamint a kénatom képződéshőjét összehasonlítva látható, hogy a legpontosabb eredmények a legmagasabb szinteket használó, csonkítás nélküli HEAT-345(Q) protokollal (4. modell) számíthatók, kombinálva az itt meghatározott $\Delta_{f} H_{0}^{\circ}(\mathrm{S})$ és $\Delta_{f} H_{298}^{\circ}(\mathrm{S})$ adatokkal. A két utóbbi mennyiségre vonatkozó NIST-JANAF érték hibája nyilvánvaló, az ezekkel számított eredmények mind a négy modell esetén jelentősen eltérnek az irodalmiaktól, míg a jelen munkában bevezetett atomi képződéshôk jóval pontosabb értékeket szolgáltatnak. Ezek alapján az új $\Delta_{f} H_{0}^{\circ}(\mathrm{S})$ és $\Delta_{f} H_{298}^{\circ}(\mathrm{S})$ adatok későbbi számításokban történő felhasználása megalapozottnak tekinthető.

A szoros- $d$ függvényekkel történő kiegészítés hatását az 1., a 2. és a 3. modell közötti különbség reprezentálja. Az 1. modell, melyben a bázisok kiegészítése nem történt meg, jelentősen gyengébben teljesített a 2. és 3. megfelelőjénél. Az $\mathrm{S}_{2}$ esetén a kérdéses modell eredményei és a referenciaadatok közötti eltérés közel $10 \mathrm{~kJ} \mathrm{~mol}^{-1}$, míg az $\mathrm{SO}_{2}$ esetén több, mint $20 \mathrm{~kJ} \mathrm{~mol}^{-1}$. Az egyensúlyi szerkezetek és a rezgési analízis (azaz a ZPE) számításához is kiegészített bázisokat használó 3. modell eredményei mindössze egy-két tized $\mathrm{kJ} \mathrm{mol}^{-1}$-el térnek el a végleges 2 . modell értékeitől. Ez alapján kijelenthetjük, hogy a geometriai optimalizáláshoz a szoros- $d$ függvényekkel történő kiegészítés nem feltétlenül szükséges, így - egyes esetekben - jelentős számítási időt és kapacitást spórolhatunk. Azonban a protokolláris összegzés megfelelő hozzájárulásaihoz a bázisok kiegészítése feltétlenül szükséges. 
5.19. táblázat

A tesztkészlet különbözô modellekkel számított képződéshői ( $\left.\mathrm{kJ} \mathrm{mol}^{-1}\right) 0$ és $298 \mathrm{~K}$-en.

$\Delta_{f} H^{\circ}(\mathrm{S})(1)$ : A kénatom NIST-JANAF képződéshőjével számított értékek;

$\Delta_{f} H^{\circ}(\mathrm{S})(2)$ : A kénatom általunk számított képződéshőjével kapott értékek.

(a) $\mathrm{S}_{2}$

\begin{tabular}{crr||cc}
\hline \hline & \multicolumn{2}{c||}{$\Delta_{f} H_{T}^{\circ}(\mathrm{S})(1)$} & \multicolumn{2}{c}{$\Delta_{f} H_{T}^{\circ}(\mathrm{S})(2)$} \\
\cline { 2 - 5 } Modell & $0 \mathrm{~K}$ & $298 \mathrm{~K}$ & $0 \mathrm{~K}$ & $298 \mathrm{~K}$ \\
\hline \hline 1. & 119.9 & 120.0 & 124.9 & 125.1 \\
2. & 122.4 & 122.5 & 127.4 & 127.5 \\
3. & 122.3 & 122.4 & 127.3 & 127.4 \\
4. & 123.3 & 123.4 & 128.3 & 128.4 \\
\hline
\end{tabular}

Referencia (NIST-JANAF)

\begin{tabular}{cc}
$0 \mathrm{~K}$ & $298 \mathrm{~K}$ \\
\cline { 2 - 2 } & 128.3 \\
\hline
\end{tabular}

(c) $\mathrm{SO}$

\begin{tabular}{crr||cr}
\hline \hline & \multicolumn{2}{c||}{$\Delta_{f} H_{T}^{\circ}(\mathrm{S})(1)$} & \multicolumn{2}{c}{$\Delta_{f} H_{T}^{\circ}(\mathrm{S})(2)$} \\
\cline { 2 - 5 } Modell & $0 \mathrm{~K}$ & $298 \mathrm{~K}$ & $0 \mathrm{~K}$ & $298 \mathrm{~K}$ \\
\hline \hline 1. & -0.4 & -0.4 & 2.2 & 2.1 \\
2. & 3.0 & 3.0 & 5.6 & 5.5 \\
3. & 2.9 & 2.9 & 5.5 & 5.4 \\
4. & 3.5 & 3.4 & 6.0 & 5.9 \\
\hline
\end{tabular}

Referencia (NIST-JANAF)

\begin{tabular}{cc}
$0 \mathrm{~K}$ & $298 \mathrm{~K}$ \\
\hline 5.0 & 5.0 \\
\hline
\end{tabular}

(b) $\mathrm{H}_{2} \mathrm{~S}$

\begin{tabular}{crr||rr}
\hline & \multicolumn{2}{c||}{$\Delta_{f} H_{T}^{\circ}(\mathrm{S})(1)$} & \multicolumn{2}{c}{$\Delta_{f} H_{T}^{\circ}(\mathrm{S})(2)$} \\
\cline { 2 - 5 } Modell & $0 \mathrm{~K}$ & $298 \mathrm{~K}$ & $0 \mathrm{~K}$ & $298 \mathrm{~K}$ \\
\hline \hline 1. & -21.3 & -24.4 & -18.7 & -21.9 \\
2. & -20.0 & -23.2 & -17.5 & -20.6 \\
3. & -19.9 & -23.0 & -17.4 & -20.5 \\
4. & -19.6 & -22.7 & -17.1 & -20.2 \\
\hline
\end{tabular}

Referencia (NIST-JANAF)

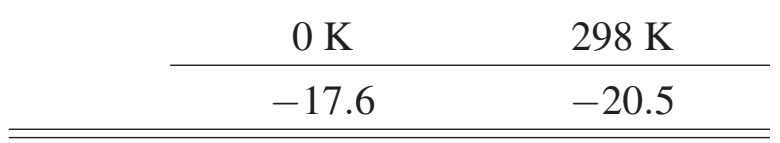

(d) $\mathrm{SO}_{2}$

\begin{tabular}{crr||rr}
\hline \hline & \multicolumn{2}{c||}{$\Delta_{f} H_{T}^{\circ}(\mathrm{S})(1)$} & \multicolumn{2}{c}{$\Delta_{f} H_{T}^{\circ}(\mathrm{S})(2)$} \\
\cline { 2 - 5 } Modell & $0 \mathrm{~K}$ & $298 \mathrm{~K}$ & $0 \mathrm{~K}$ & $298 \mathrm{~K}$ \\
\hline \hline 1. & -315.3 & -317.9 & -312.8 & -315.4 \\
2. & -298.6 & -301.2 & -296.1 & -298.7 \\
3. & -298.8 & -301.4 & -296.3 & -298.9 \\
4. & -297.9 & -300.4 & -295.3 & -297.9 \\
\hline
\end{tabular}

Referencia (NIST-JANAF)

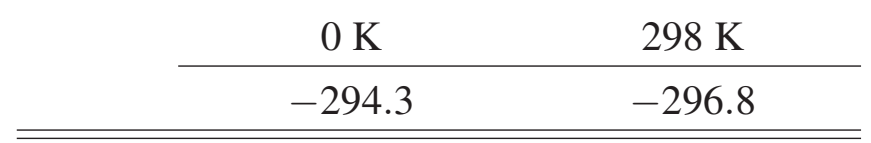



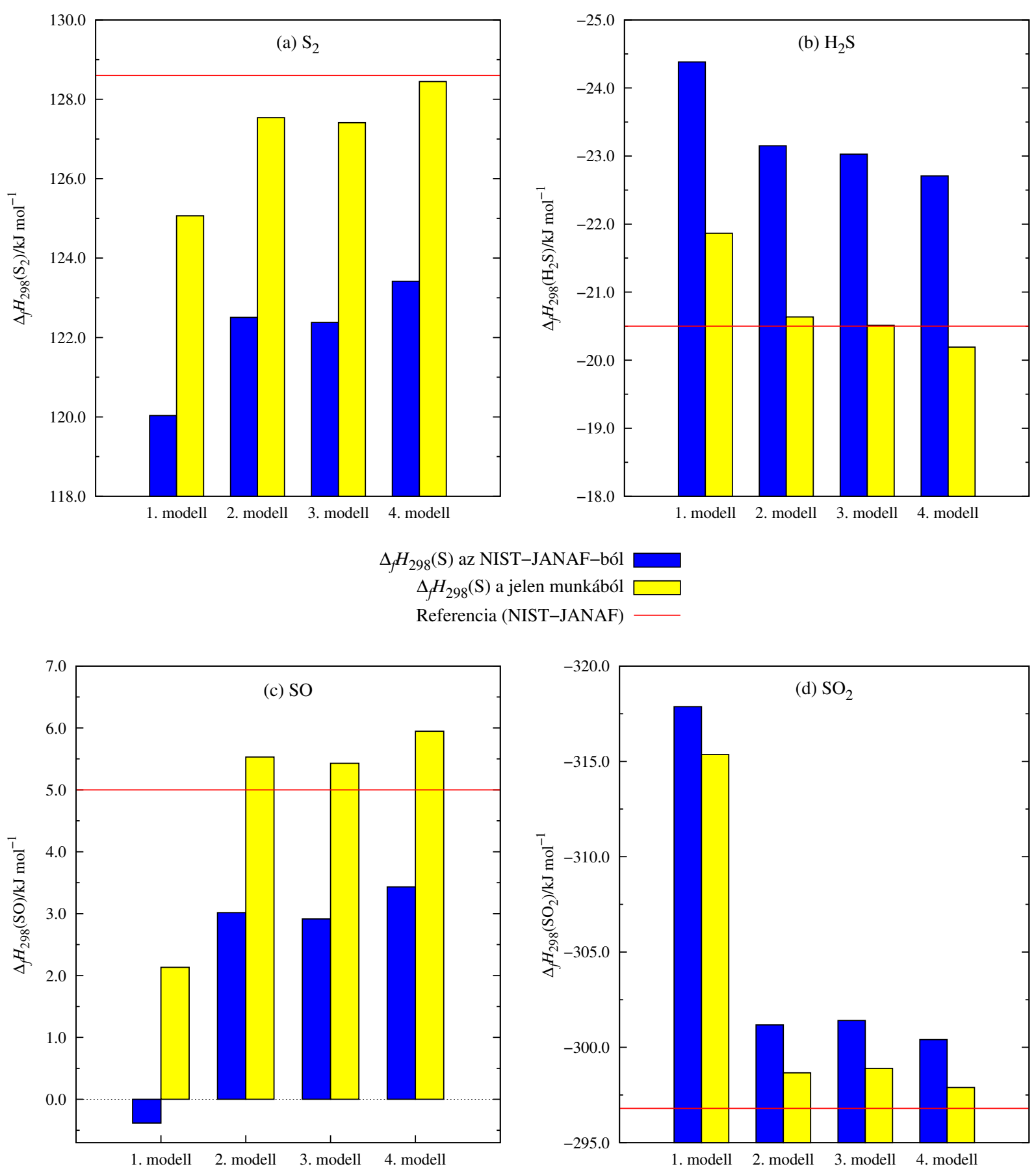

5.5. ábra

Az $\mathrm{S}_{2}, \mathrm{H}_{2} \mathrm{~S}$, SO és $\mathrm{SO}_{2}$ molekulák képződési entalpiája $298 \mathrm{~K}$-en a különböző modellekkel számítva a kénatom kétféle képződéshőjével 


\subsection{Termodinamikai függvények}

A következő fejezetekben röviden összefoglalva bemutatom a jelen dolgozatban vizsgált molekulák és gyökök termodinamikai függvényeinek irodalmi értékeit, összehasonlítva az általam számított adatokkal. Azokban az esetekben, ahol az egyes referenciák közötti jelentős inkonzisztencia ezt szükségessé teszi, a diszkusszió részletesebb. Eredményeimet a termikus korrekciókra, képződési entalpiákra és standard moláris entrópiákra az 5.18. táblázat tartalmazza, míg a fejezet végén az 5.36. táblázatban a referenciaként használható értékeket listáztam.

\subsubsection{Formaldehid}

A formaldehid képződési entalpiájának irodalmi értékei (5.20. táblázat) jól szemléltetik azt a tényt, melyet már korábban említettünk, és a későbbiekben a molekula származékainál valamint a kéntartalmú vegyületeknél is látni fogunk, hogy az egyes forrásadatok között komoly, jelen esetben több mint $15 \mathrm{~kJ} \mathrm{~mol}^{-1}$-es eltérések is lehetnek. Az ilyen mértékú differencia már meghaladja az egyes értékekhez tartozó bizonytalanságot, hibahatárt.

Az NIST-JANAF adatbázis ${ }^{19}$ több kísérleti eredményt is tárgyal a formaldehid képződési entalpiájával kapcsolatban, melyek közül végül Wartenberg és Learner-Steinberg ${ }^{209}$ 1925-ös, égési kísérletekből meghatározott adatát, $\Delta_{f} H_{0}^{\circ}=-112.1 \pm 6.3 \mathrm{~kJ} \mathrm{~mol}^{-1}$ és $\Delta_{f} H_{298}^{\circ}=-115.9 \pm 6.3$ $\mathrm{kJ} \mathrm{mol}^{-1}$, fogadja el a legmegbízhatóbbnak. Az adatbázis ezen kívül tárgyalja Delepine és Badoche $210-104.6 \mathrm{~kJ} \mathrm{~mol}^{-1}$-es képződési entalpiáját is. Az érték a szerzőpáros által egy formaldehid polimerre mért égéshőből származik, melyet a

$$
\begin{aligned}
\mathrm{C}(\mathrm{cr})+\frac{1}{2} \mathrm{O}_{2}(\mathrm{~g})+\mathrm{H}_{2}(\mathrm{~g})=\frac{1}{n}\left(\mathrm{CH}_{2} \mathrm{O}\right)_{n}(\mathrm{cr}) & \Delta_{r} \mathrm{H}=-177.0 \mathrm{~kJ} \mathrm{~mol}^{-1} \\
\frac{1}{n}\left(\mathrm{CH}_{2} \mathrm{O}\right)_{n}(\mathrm{cr})+\mathrm{H}_{2} \mathrm{O}=\mathrm{CH}_{2} \mathrm{O}(\mathrm{aq}) & \Delta_{r} H=10.0 \mathrm{~kJ} \mathrm{~mol}^{-1} \\
\mathrm{CH}_{2} \mathrm{O}(\mathrm{g})=\mathrm{CH}_{2} \mathrm{O}(\mathrm{aq}) & \Delta_{r} H=62.3 \mathrm{~kJ} \mathrm{~mol}^{-1}
\end{aligned}
$$

termokémiai ciklus alapján korrigáltak. Az NIST-JANAF ${ }^{19}$ által tárgyalt harmadik kísérleti képzôdési entalpia Newton és Dodge ${ }^{211}$ értéke, $\Delta_{f} H_{298}^{\circ}=-121.3 \mathrm{~kJ} \mathrm{~mol}^{-1}$, melyet a $\mathrm{H}_{2}(\mathrm{~g})+\mathrm{CO}(\mathrm{g})$ $\rightleftharpoons \mathrm{H}_{2} \mathrm{CO}(\mathrm{g})$ folyamat egyensúlyi állandójának mérése alapján származtattak 1933-ban. Érdemes megjegyezni, hogy az NIST-JANAF referenciaértékéhez tartozó, relatíve magasnak mondható \pm $\pm 6.3 \mathrm{~kJ} \mathrm{~mol}^{-1}$-es bizonytalanság eredete ismeretlen, nem derül ki sem a táblázat diszkussziójából, sem az ott hivatkozott irodalomból.

A magasabb szintú elméleti számítások, valamint az újraértékelések eredményei a kísérletiekkel szemben már sokkal konzisztensebbnek mutatkoznak. 
5.20. táblázat

A formaldehid irodalmi képződési entalpiája 0 és $298.15 \mathrm{~K}$ hőmérsékleten $\mathrm{kJ} \mathrm{mol}^{-1}$ egységben

\begin{tabular}{|c|c|c|}
\hline$\Delta_{f} H_{0}^{\circ}$ & $\Delta_{f} H_{298}^{\circ}$ & Módszer és referencia \\
\hline \multicolumn{3}{|l|}{ Kisérlet } \\
\hline \multirow{4}{*}{$-112.1 \pm 6.3$} & $-115.9 \pm 6.3$ & 19,209 \\
\hline & -104.6 & 210 \\
\hline & $-108.6 \pm 0.5$ & 212 \\
\hline & -121.3 & 211 \\
\hline \multicolumn{3}{|l|}{ Számítás } \\
\hline \multirow[t]{2}{*}{-113.0} & -116.7 & $\mathrm{G} 2,213$ \\
\hline & -111.3 & CBS-QB3, 214 \\
\hline \multirow[t]{2}{*}{-105.3} & -109.2 & $\mathrm{~W} 4,50$ \\
\hline & $-109.8 \pm 1.8$ & 215 \\
\hline-104.8 & -108.7 & HEAT, 37 \\
\hline \multicolumn{3}{|l|}{ Újraértékelés } \\
\hline & $-108.6 \pm 0.5$ & 216 \\
\hline & $-108.6 \pm 0.5$ & 217 \\
\hline \multirow[t]{5}{*}{$-104.9 \pm 0.5$} & $-108.7 \pm 0.5$ & 218 \\
\hline & $-117.2 \pm 6.3$ & 219 \\
\hline & -108.8 & 220 \\
\hline & -108.6 & 221 \\
\hline & -108.5 & 222 \\
\hline \multicolumn{3}{|c|}{ Jelen munka (FPA) } \\
\hline$-105.42 \pm 0.40$ & $-109.23 \pm 0.40$ & \\
\hline
\end{tabular}

A korai G2 és CBS módszereken alapuló eredmények a Wartenberg-féle ${ }^{209}$ NIST-JANAF, ${ }^{19}$ valamint a Stull-féle ${ }^{219}$ újraértékelésből származó értékeket támogatják. A két elméleti úton számított adat közötti különbség számottevő, közel $5 \mathrm{~kJ} \mathrm{~mol}^{-1}$, azonban a két említett referencia 6.3 $\mathrm{kJ} \mathrm{mol}^{-1}$-es bizonytalansága alapján mindkét elméleti értéket helyesnek fogadhatjuk el.

A három magasabb szintû és egymással jó egyezést mutató elméleti eredmény sokkal inkább a Fletcher-féle $-108.6 \pm 0.5 \mathrm{~kJ} \mathrm{~mol}^{-1}$-es (298.15 K) kísérleti, valamint a legtöbb újraértékelésből származó adat helyességét támasztja alá. A W4 ${ }^{50}$ és a HEAT modellekkel ${ }^{37,51}$ az atomizációs energia bázisán számított eredmények konzisztensek a da Silva és társai ${ }^{215}$ által közöltekkel. Utóbbi adat egy átlagolt eredmény, melyet összesen 6 termokémiai modellel (CBS-Q, CBS-Q//B3, CBSAPNO, G2, G3 és G3B3) izodezmikus és atomizációs reakciókra végzett számítások bázisán határoztak meg. A fenti táblázatban a legkisebb bizonytalansággal rendelkező átlagolt végeredmény 
szerepel.

A jelen dolgozatban az FPA modell keretein belül 0 és 298.15 K-en számított képződési entalpiák, $-105.42 \pm 0.40$ és $-109.23 \pm 0.40 \mathrm{~kJ} \mathrm{~mol}^{-1}$, kiválóan egyeznek a W4 számítási és a Fletcher-féle kísérleti eredményekkel. Mivel az itt közölt entalpiaértékek rendelkeznek a legkisebb bizonytalanságokkal és az elméletiek közül ezek a legmagasabb szinten számítottak, ezért mindenképpen javasoljuk referenciaként történő felhasználásukat a későbbi termokémiai számítások során.

\subsubsection{A formaldehid származékai}

\section{$\mathrm{F}_{2} \mathrm{CO}$}

A karbonil-difluorid, $\mathrm{F}_{2} \mathrm{CO}$, néhány termokémiai mennyiségének összegyűjtött irodalmi értékét az 5.21. táblázat összegzi.

Az NIST-JANAF adatbázis ${ }^{19}$ három experimentális adatot ${ }^{223-225}$ tárgyal az $\mathrm{F}_{2} \mathrm{CO}$ képződési entalpiájával kapcsolatosan. Ezek közül a Wartenberg és Riteris ${ }^{224}$ által javasolt, az $\mathrm{F}_{2} \mathrm{CO}$ hidrolizációs entalpiájából származó értéket, $\Delta_{f} H_{298}^{\circ}\left(\mathrm{F}_{2} \mathrm{CO}\right)=-638.9 \pm 1.7 \mathrm{~kJ} \mathrm{~mol}^{-1}$, fogadja el. Ruff és $\mathrm{Li}^{223}$ a $2 \mathrm{CF}_{2} \mathrm{O} \rightleftharpoons \mathrm{CO}_{2}+\mathrm{CF}_{4}$ folyamat egyensúlyi állandóját tanulmányozta az $573-1273 \mathrm{~K}$ es hőmérséklettartományban. Az 5 legmagasabb hőmérsékletû mérési pont eredményeiből Stull és munkatársai $\Delta_{r} H_{298}^{\circ}=-50.2 \pm 12.6 \mathrm{~kJ} \mathrm{~mol}^{-1}$ reakcióentalpiát származtattak, melyből a karbonildifluorid képződési entalpiája $-638.1 \pm 13.8 \mathrm{~kJ} \mathrm{~mol}^{-1}$-nek adódott. Végül Armstrong et al. ${ }^{225}$ a metán égéshőjét mérte $\mathrm{O}_{2} / \mathrm{F}_{2}$ atmoszférában és a valamivel alacsonyabb, $-647.7 \mathrm{~kJ} \mathrm{~mol}^{-1}$-es értéket közölte.

\subsection{1. táblázat}

Az $\mathrm{F}_{2} \mathrm{CO}$ irodalmi termodinamikai paraméterei. A képződési entalpiák $\mathrm{kJ} \mathrm{mol}^{-1}$, az entrópiák $\mathrm{J} \mathrm{K}^{-1} \mathrm{~mol}^{-1}$ egységben szerepelnek.

\begin{tabular}{|c|c|c|c|}
\hline$\Delta_{f} H_{0}^{\circ}$ & $\Delta_{f} H_{298}^{\circ}$ & $S_{298}^{\circ}$ & Módszer és referencia ${ }^{a}$ \\
\hline \multicolumn{4}{|l|}{ Kisérlet } \\
\hline \multirow[t]{5}{*}{$-635.8 \pm 1.7^{\mathrm{c}}$} & $-638.9 \pm 1.7^{\mathrm{c}}$ & & 19,224 \\
\hline & $\geq-623.8_{-2.9}^{+5.9 c}$ & & 20,226 \\
\hline & $-638.1 \pm 13.8$ & & 19,223 \\
\hline & -647.7 & & 19,225 \\
\hline & & $258.9 \pm 0.1^{b}$ & 19,227 \\
\hline
\end{tabular}

Számítás

$$
-607.1 \pm 2.1 \quad \text { CC, } 77
$$$$
-607.5 \pm 3.4 \quad \text { CC, } 70
$$$$
-602.1 \pm 4.2-605.4 \pm 4.2 \quad \text { CC, } 228
$$

Folytatás a következó oldalon... 
5.21. táblázat - Folytatás az előző oldalról

\begin{tabular}{|c|c|c|c|}
\hline$\Delta_{f} H_{0}^{\circ}$ & $\Delta_{f} H_{298}^{\circ}$ & $S_{298}^{\circ}$ & Módszer és referencia ${ }^{a}$ \\
\hline & $-609.6 \pm 4.2$ & & CBS-QCI, 229 \\
\hline & $-605.0 \pm 5.1$ & & $\mathrm{G} 2,31$ \\
\hline & $-607.9 \pm 7.1$ & & G2(MP2), 111 \\
\hline & $-606.7 \pm 8.8$ & & ATOMIC, 230 \\
\hline & -598.3 & & BAC-MP4, 231 \\
\hline & -609.6 & & $\mathrm{G} 3,232$ \\
\hline & -606.8 & & AAC-G2, 233 \\
\hline & -606.3 & & AAC-G2(MP2), 233 \\
\hline \multicolumn{4}{|l|}{ Újraértékelés } \\
\hline & $-641.0 \pm 0.8$ & & 219 \\
\hline & $-640.6 \pm 5.9$ & & 234 \\
\hline & $-640.6 \pm 5.0$ & 259.0 & 218 \\
\hline
\end{tabular}

Jelen munka [HEAT-345(Q)]

$-606.5 \pm 1.2 \quad-603.4 \pm 1.2 \quad 258.6 \pm 1.5$

a A CC rövidítés coupled-cluster módszeren alapuló kompozit protokollra utal.

b Az NIST-JANAF adatbázisban ${ }^{19}$ elfogadott érték.

c A JPL adatbázis ${ }^{20}$ által elfogadott érték.

Az elérhető kísérleti adatok részletes analízisét találjuk Stull, Westrum és Sinke könyvében. ${ }^{219}$ Kiértékelésükben a legnagyobb súllyal Wartenberg és Riteris kalorimetriás eredménye szerepelt, és ezzel $-641.0 \pm 0.8 \mathrm{~kJ} \mathrm{~mol}^{-1}$-et kaptak a $\Delta_{f} \mathrm{H}_{298}^{\circ}\left(\mathrm{F}_{2} \mathrm{CO}\right)$-ra. Ezzel összhangban Amphlett és kollégái ${ }^{234}$ a $\Delta_{f} H_{298}^{\circ}\left(\mathrm{F}_{2} \mathrm{CO}\right)=-640.6 \pm 5.9 \mathrm{~kJ} \mathrm{~mol}^{-1}$-es értéket közölték Ruff és Li egyensúlyi ereményeinek tökéletesítéséből.

1994-ben több, elméleti számításon alapuló eredmény is napvilágot látott (lásd az 5.21. táblázatot). Nyden és csoportja, ${ }^{231}$ Montgomery és munkatársai, ${ }^{229}$ valamint Schneider és Wallington ${ }^{111}$ különböző termokémiai protokollok és számítási szintek alkalmazásával a kísérleti eredményeknél jóval magasabb entalpiaértékeket közöltek. A több mint $30 \mathrm{~kJ} \mathrm{~mol}^{-1}$-es eltérések miatt mindhárom csoport az experimentális adatok újrakiértékelését javasolta.

A kísérleti és a számított eredmények közötti diszkrepancia feloldásának érdekében Ruscic és csoportja $^{226}$ fotoionizációs spektrometriás (PIMS) méréseket végzett az $\mathrm{F}_{2} \mathrm{CO}$-ra. Ugyan konkrét képződési entalpia értéket nem adtak meg, azonban egy alsó korlátot, $\Delta_{f} H_{298}^{\circ}\left(\mathrm{F}_{2} \mathrm{CO}\right) \geq-623.8_{-2.9}^{+5.9}$ $\mathrm{kJ} \mathrm{mol}^{-1}$ felállítottak a kérdéses mennyiségre. A JPL adatbázis ${ }^{20}$ ezt az értéket fogadja el referenciaként. Erre az eredményre hivatkozva Ruscic és munkatársai azt a következtetést vonták le, hogy a kísérletből származó adatok kb. $15 \mathrm{~kJ} \mathrm{~mol}^{-1}$-el mélyebbek, míg a számítottak ugyanennyivel magasabbak a tényleges értéknél. Mindazonáltal azt is megjegyezték, hogy a kísérletük természetéből fakadóan az elméleti képződési entalpiák nem zárhatók ki teljes bizonyossággal : további kísérletek 
és számítások szükségesek az ellentmondások feloldásához.

Ruscic-ék PIMS mérései óta kizárólag számításos módszerekkel meghatározott képződési entalpiákkal foglalkozó közlemények ${ }^{70,77,228,230,232,233,235}$ láttak napvilágot. Feller és Dixon ${ }^{70}$ a $\mathrm{CH}_{2} \mathrm{O}+\mathrm{CF}_{2} \mathrm{H}_{2}=\mathrm{CF}_{2} \mathrm{O}+\mathrm{CH}_{4}$ izodezmikus reakció valamint az atomizációs energia bázisán $-607.5 \pm 3.4 \mathrm{~kJ} \mathrm{~mol}^{-1}$-et javasol a $\Delta_{f} H_{0}^{\circ}\left(\mathrm{F}_{2} \mathrm{CO}\right)$ mennyiségre. Számításaikat CCSD(T) szinten végezték az aug-cc-pV(D,T,Q)Z bázisokkal extrapolálva. Figyelembe vették a vegyérték- és magelektronok korrelációját, valamint számoltak a spin-pálya csatolás hozzájárulásával is.

Kondo és munkatársai ${ }^{233}$ BAC és AAC módszerekkel kiegészített MP2, valamint AAC-vel kiegészített G2 és G2(MP2) számításokat végeztek nagy számú közepes méretű fluor tartalmú szerves származékra. A két legpontosabb eredményük az $\mathrm{F}_{2} \mathrm{CO}$ képződési entalpiájára $298 \mathrm{~K}$ en az AAC-G2 és AAC-G2(MP2) számításokból származik, melyek rendre -606.8 és -606.3 $\mathrm{kJ} \mathrm{mol}^{-1}$-nek adódtak.

Dixon és csoportja ${ }^{228}$ a korábban használt módszerének ${ }^{70}$ továbbfejlesztett verziójával a CHFO és a $\mathrm{CF}_{2} \mathrm{O}$ termokémiai paramétereit - többek között ionizációs potenciálját (IP) és képződési entalpiáját - számította. A protokoll leglényegesebb fejlesztése a skaláris relativisztikus hatások figyelembevétele volt. A $\Delta_{f} H_{0}^{\circ}\left(\mathrm{F}_{2} \mathrm{CO}\right)$ és $\Delta_{f} H_{298}^{\circ}\left(\mathrm{F}_{2} \mathrm{CO}\right)$ mennyiségekre rendre $-602.1 \pm 4.2$ és $-605.4 \pm 4.2 \mathrm{~kJ} \mathrm{~mol}^{-1}$ adódott. Érdemes megjegyezni, hogy a számított IP-ok jó egyezést mutattak a kísérletileg meghatározottakkal. Ebből következően Dixon és munkatársai a fotoionizációs kísérletekben esetleges szisztematikus hiba előfordulását valószínúsítették. ${ }^{228}$

Bakowies az általa 2009-ben kidolgozott $\mathrm{ATOMIC}^{67}$ protokollal szintén foglalkozott az $\mathrm{F}_{2} \mathrm{CO}$ molekulával. Modelljének legpontosabb verziója $-606.7 \pm 8.8 \mathrm{~kJ} \mathrm{~mol}^{-1}$-et eredményezett a $\Delta_{f} H_{298}^{\circ}\left(\mathrm{F}_{2} \mathrm{CO}\right)-$ ra. $^{230}$

Feller, Peterson és Dixon 2008-ban egy részletesen kidolgozott tanulmányban ${ }^{77}$ vizsgált néhány olyan tényezőt, mely elengedhetetlenül fontos az atomizációs energiák nagy pontosságú meghatározásához. Munkájukban további nagy számú kisebb - nyílt és zárt héjú - kémiai rendszer képződési entalpiáját is számították. Modellük $-607.1 \pm 2.1 \mathrm{~kJ} \mathrm{~mol}^{-1}$-et adott a $\Delta_{f} H_{298}^{\circ}\left(\mathrm{F}_{2} \mathrm{CO}\right)$ ra.

Az általunk használt, a 4.1.2 fejezetben definiált modell $-603.4 \pm 1.2$ és $-606.5 \pm 1.2$ $\mathrm{kJ} \mathrm{mol}^{-1}$ értékeket eredményezett a $\Delta_{f} H_{0}^{\circ}\left(\mathrm{F}_{2} \mathrm{CO}\right)$ és $\Delta_{f} H_{298}^{\circ}\left(\mathrm{F}_{2} \mathrm{CO}\right)$ mennyiségekre. Látható, hogy az adatok remek egyezést mutatnak a Feller és csoportja által közölttel, ami, figyelembe véve a két modell hasonlóságát, nem meglepő. Mindemellett néhány hozzájárulást a jelen munkában nagyobb pontossággal határoztunk meg. A két modell tulajdonképpen három számottevő pontban tér el, melyek mindegyike néhány tized $\mathrm{kJ} \mathrm{mol}^{-1}$-nek megfelelő hibát eredményez a végsố entalpiákban. Az eltérések a következők: (i) A CCSDT hozzájárulás jelen munkában a cc-pV(T,Q)Z bázisokból történô extrapolációból származik, míg Fellerék extrapoláció nélkül a cc-pVTZ eredményeket használták; (ii) jelen munkában nem választottuk szét a mag- és vegyértékelektronok korrelációs hatásait, azaz all-electron számításokat végeztünk; (iii) a zéruspont rezgési energia harmonikus és anharmonikus hozzájárulását egyaránt a cc-pVQZ bázissal határoztuk meg, míg 
Feller és csoportja rendre a cc-pVTZ és cc-pVDZ bázisokat használták.

A fentieket összegezve tehát megállapíthatjuk, hogy a kísérleti eredmények alapján a $\Delta_{f} H_{298}^{\circ}\left(\mathrm{F}_{2} \mathrm{CO}\right)-647.7$ és $-623.8 \mathrm{~kJ} \mathrm{~mol}^{-1}$ között helyezkedik el. Itt ismét hangsúlyoznánk, hogy $\mathrm{a}-623.8 \mathrm{~kJ} \mathrm{~mol}^{-1}$-es érték tulajdonképpen egy alsó korlát, azaz a képződési entalpiának ennél magsabbnak kell lennie. Másrészről a magas szintû elméleti kémiai számítások, melyek más hasonló kémiai rendszereknél rendkívül hatékonynak bizonyultak, egymással konzekvens adatokat szolgáltattak a $\Delta_{f} H_{298}^{\circ}\left(\mathrm{F}_{2} \mathrm{CO}\right)$ mennyiségre, a $-623.8 \mathrm{~kJ} \mathrm{~mol}^{-1}$-es korlátnak megfelelően. Mindezek alapján javasoljuk a kísérleti adatok revízióját.

Mivel az elméleti módszerek közül a mi HEAT-345(Q) protokollunk a legmagasabb szintú, így nyilvánvalóan a legpontosabb is, ezért az általunk meghatározott képződési entalpia értékeket, $\Delta_{f} H_{0}^{\circ}\left(\mathrm{F}_{2} \mathrm{CO}\right)=-603.4 \pm 1.2 \mathrm{~kJ} \mathrm{~mol}^{-1}$ és $\Delta_{f} H_{298}^{\circ}\left(\mathrm{F}_{2} \mathrm{CO}\right)=-606.5 \pm 1.2 \mathrm{~kJ} \mathrm{~mol}^{-1}$, mint új referenciaadatokat javasoljuk későbbi felhasználásra.

A $\mathrm{F}_{2} \mathrm{CO}$ standard moláris entrópiájára a NIST-JANAF adatbázis ${ }^{19} 258.9 \pm 0.1 \mathrm{~J} \mathrm{~K}^{-1} \mathrm{~mol}^{-1}$-et javasol, melyet Hopper és munkatársai ${ }^{227}$ által közölt rezgési frekvenciákból számítottak. A JPL gyưjitemény ${ }^{20}$ a Gurvich könyvében ${ }^{218}$ szereplő $259.0 \mathrm{~J} \mathrm{~K}^{-1} \mathrm{~mol}^{-1}$-es értéket fogadja el. Az általunk számított adat, $S_{298}^{\circ}\left(\mathrm{F}_{2} \mathrm{CO}\right)=258.6 \pm 1.5 \mathrm{~J} \mathrm{~K}^{-1} \mathrm{~mol}^{-1}$, jó egyezést mutat az experimentális mérésekből származtatott eredményekkel, noha a hibahatár nagyobb, mint az NIST-JANAF táblázatban közölt érték esetén.

\section{FCO}

A karbonil-fluorid gyök, FCO, képződési entalpiájának kísérletileg mért adatai között, az előző fejezetben tárgyalt $\mathrm{F}_{2} \mathrm{CO}$ molekulához hasonlóan, jelentős különbségek vannak (5.22. táblázat). A legtöbb érték csak becslés, esetleg alsó vagy felső korlát a kérdéses mennyiséghez. Ezentúl szinte az összes kísérleti eredmény nagy hibával szerepel, ami bonyodalmakat okozhat olyan számításokban, ahol a gyök pontos termokémiai adataira lenne szükség. ${ }^{236}$

\subsection{2. táblázat}

Az FCO gyök irodalmi termodinamikai paraméterei. A képződési entalpiák kJ mol${ }^{-1}$, az entrópiák $\mathrm{J} \mathrm{K}^{-1} \mathrm{~mol}^{-1}$ egységben szerepelnek.

\begin{tabular}{rrrr}
\hline \hline \multicolumn{1}{c}{$\Delta_{f} H_{0}^{\circ}$} & \multicolumn{1}{c}{$\Delta_{f} H_{298}^{\circ}$} & $S_{298}^{\circ}$ & Módszer és referencia $^{\mathrm{a}}$ \\
\hline \hline Kísérlet & & \\
-141.4 & $-142.3 \pm 21.0$ & 236 \\
& $\geq-255.2$ & \\
& $\leq-154.8$ & 237 \\
& $-175.7 \pm 16.7$ & \\
-276.1 & & 238 \\
$-152.7 \pm 12.0$ & $-152.1 \pm 12.0$ & 108
\end{tabular}

Folytatás a következő oldalon... 
5.22. táblázat - Folytatás az előző oldalról

\begin{tabular}{|c|c|c|c|}
\hline$\Delta_{f} H_{0}^{\circ}$ & $\Delta_{f} H_{298}^{\circ}$ & $S_{298}^{\circ}$ & Módszer és referencia ${ }^{\mathrm{a}}$ \\
\hline & $-161.2 \pm 8.1^{b}$ & & 239 \\
\hline \multicolumn{4}{|l|}{ Számítás } \\
\hline \multirow[t]{5}{*}{$-179.5 \pm 3.3$} & & & MP4(SDTQ), 240 \\
\hline & -178.7 & & $\mathrm{G} 3,232$ \\
\hline & -179.9 & & G3[MP2(full)], 232 \\
\hline & -177.4 & & G3[MP4(SDQ)], 232 \\
\hline & $-182.9 \pm 7.4$ & & BAC-MP4, 241 \\
\hline$-184.5 \pm 2.1$ & & & $\mathrm{CC}, 70$ \\
\hline \multirow[t]{2}{*}{-180.6} & -179.9 & 249.0 & G3MP2B3, 242 \\
\hline & -177.8 & & W1U, 243 \\
\hline$-176.1 \pm 2.1$ & $-175.7 \pm 2.1$ & & $\operatorname{CCSD}(\mathrm{T}), 244$ \\
\hline \multicolumn{4}{|l|}{ Újraértékelés } \\
\hline$-172.1 \pm 63.0$ & $-171.5 \pm 63.0$ & 248.5 & 19 \\
\hline$-179.4 \pm 40.0$ & $-180.0 \pm 40.0$ & 249.0 & 22,218 \\
\hline \multicolumn{4}{|c|}{ Jelen munka $[H E A T-345(Q)]$} \\
\hline$-177.2 \pm 0.9$ & $-176.7 \pm 0.9$ & $248.8 \pm 1.5$ & \\
\hline
\end{tabular}

a A CC rövidítés coupled-cluster módszeren alapuló kompozit protokollra utal.

b A JPL adatbázis ${ }^{20}$ által elfogadott érték.

A legelterjedtebb kísérleti módszer a $\Delta_{f} H_{298}^{\circ}(\mathrm{FCO})$ mennyiség meghatározására az F-CO kötés disszociációs entalpiájának, $\left(D_{298}^{\circ}(\mathrm{F}-\mathrm{CO})\right)$, mérésén alapul, melyből az 5.3. összefüggés 237 szerint számítható a képződési entalpia:

$$
\Delta_{f} H_{298}^{\circ}(\mathrm{FCO})=\Delta_{f} H_{298}^{\circ}(\mathrm{F})+\Delta_{f} H_{298}^{\circ}(\mathrm{CO})-D_{298}^{\circ}(\mathrm{F}-\mathrm{CO}) .
$$

A $\Delta_{f} H_{298}^{\circ}(\mathrm{F})$ és $\Delta_{f} H_{298}^{\circ}(\mathrm{CO})$ mennyiségek értékei általában adatbázisokból származó, pontos kísérleti adatok. A problémát a kötésdisszociációs entalpia korántsem kézenfekvő kísérleti meghatározása jelenti: a kinetikai módszerek vagy az ion transzfer folyamatok eredményei legtöbbször csak durva becslései a mennyiségnek.

Az NIST-JANAF kompendium ${ }^{19} \Delta_{f} H_{0}^{\circ}(\mathrm{FCO})=-172.1 \pm 63.0 \mathrm{~kJ} \mathrm{~mol}^{-1}$ és $\Delta_{f} H_{298}^{\circ}(\mathrm{FCO})=$ $-171.5 \pm 63.0 \mathrm{~kJ} \mathrm{~mol}^{-1}$ értékeket adja a meg referenciaként. Az adatok egyrészt az $\mathrm{F}_{2} \mathrm{CO}(\mathrm{g})=$ $\mathrm{CO}(\mathrm{g})+2 \mathrm{~F}(\mathrm{~g})$ folyamat standard reakcióentalpiáján alapulnak, másrészt azon az egyszerú feltételezésen, hogy $D_{0}^{\circ}(\mathrm{Cl}-\mathrm{CO}) / D_{0}^{\circ}(\mathrm{Cl}-\mathrm{COCl})=D_{0}^{\circ}(\mathrm{F}-\mathrm{CO}) / D_{0}^{\circ}(\mathrm{F}-\mathrm{COF})=4$.

Macneil és Thynne ${ }^{245}$ disszociatív elektronbefogási reakciója alapján $\left(\mathrm{F}_{2} \mathrm{CO}+e^{-}=\mathrm{FCO}+\right.$ $\mathrm{F}^{-}$) a Burcat-féle adatbázis - Gurvich könyvére hivatkozva - $-179.4 \pm 40.0$ és $-180.0 \pm 40.0$ $\mathrm{kJ} \mathrm{mol}^{-1}$-et ad meg 0 és 298.15 K-en az FCO gyök képződési entalpiájára. 
Henrici és munkatársai ${ }^{236}$ az $\mathrm{F}_{2} \mathrm{O}+\mathrm{CO}$ reakció kinetikai tulajdonságait, valamint az $\mathrm{F}_{2} \mathrm{CO}$ termikus bomlását vizsgálták lökéshullám-csatornában, és mind a $D_{0}^{\circ}(\mathrm{F}-\mathrm{CO})$, mind a $\Delta_{f} H_{298}^{\circ}(\mathrm{FCO})$ mennyiségeket becsülték. Az $\mathrm{F}_{2}+\mathrm{CO} \rightarrow \mathrm{FCO}+\mathrm{F}$ és az $\mathrm{F}+\mathrm{CO} \rightarrow \mathrm{FCO}$ reakciók alapján a $\Delta_{f} H_{0}^{\circ}(\mathrm{FCO}) \leq-133.9 \mathrm{~kJ} \mathrm{~mol}^{-1}$-es felső korlátot adták meg. A teljes reakciósémájukra történő illesztésnél a $\Delta_{f} H_{0}^{\circ}(\mathrm{FCO})=-141.4 \mathrm{~kJ} \mathrm{~mol}^{-1}$-es értéknél kapták a legjobb egyezést. Végsô soron korábbi eredményekre és kvalitatív megfontolásokra hivatkozva $-142.3 \pm 21.0 \mathrm{~kJ} \mathrm{~mol}^{-1}$-et javasoltak az FCO gyök képződési entalpiájára.

Bowers és Chau ${ }^{237}$ szerint Henrici lökéshullámcső méréseinek eredményei közelítőleg 20 - 40 $\mathrm{kJ} \mathrm{mol}^{-1}$-es hibával terheltek, mivel az általuk vizsgált folyamat mechanizmusa összetettebb lehet a feltételezettnél. Ion transzfer reakciók vizsgálata alapján Bowers és Chau új alsó és felső korlátot is felállított a $\Delta_{f} H_{298}^{\circ}(\mathrm{FCO})$ mennyiségre: rendre -255.2 és $-154.8 \mathrm{~kJ} \mathrm{~mol}^{-1}$. A képződési entalpia konkrét értékére $-175.7 \pm 16.7 \mathrm{~kJ} \mathrm{~mol}^{-1}$-et közöltek, amit a korábbi kísérleti eredmények részletes analíziséből származtattak.

Egy újabb lökéshullámcsô vizsgálatban Gangloff és társai ${ }^{238}$ az F-CO és F-COF kötések disszociációs energiáját mérték. A rendelkezésükre álló korábbi eredmények részletes áttekintése után a korábbiakhoz képest jóval mélyebb $\Delta_{f} H_{0}^{\circ}(\mathrm{FCO})=-276.1 \mathrm{~kJ} \mathrm{~mol}^{-1}$-es értéket javasolták.

Buckley és munkatársai ${ }^{108}$ PIMS technikával mérte a F-COF kötés disszociációs energiáját. $\mathrm{A} \mathrm{F}_{2} \mathrm{CO} \rightarrow \mathrm{FCO}+\mathrm{F}$ reakció alapján $\Delta_{f} H_{0}^{\circ}(\mathrm{FCO})=-152.7 \pm 12.0 \mathrm{~kJ} \mathrm{~mol}^{-1}$-et és $\Delta_{f} H_{298}^{\circ}(\mathrm{FCO})$ $=-152.1 \pm 12.0 \mathrm{~kJ} \mathrm{~mol}^{-1}$-et kaptak a képződési entalpiára.

Knyazev és munkatársai ${ }^{239}$ az FCO gyök monomolekuláris bomlásának kinetikai tulajdonságait vizsgálták. A mért sebességi állandókból következetetve jutottak el a $\mathrm{FCO} \rightarrow \mathrm{CO}+\mathrm{F}$ folyamat standard entalpiájához, amiből - felhasználva a CO és az F NIST-JANAF adatait $-\Delta_{f} H_{298}^{\circ}(\mathrm{FCO})$ $=-161.2 \pm 8.1 \mathrm{~kJ} \mathrm{~mol}^{-1}$ adódott.

Francisco és Zhao ${ }^{240}$ ab initio számításokat végeztek a HCO és FCO gyökökre annak érdekében, hogy a gyökök kísérleti termodinamikai adatai közötti ellentmondásokat feloldják. Az MP4(SDTQ) elméleti szintet használtak befagyasztott mag közelítésben különböző háromszoros$\zeta$ minőségû bázisokkal, MP2 harmonikus frekvenciákkal és zéruspont rezgési energiákkal együtt. $\mathrm{Az}$ izodezmikus $\mathrm{FCO}+\mathrm{CH}_{3} \mathrm{Cl} \rightarrow \mathrm{ClCO}+\mathrm{CH}_{3} \mathrm{~F}$ és az izogirikus $\mathrm{Cl}+\mathrm{FCO} \rightarrow \mathrm{ClCO}+\mathrm{F}$ reakciók bázisán számított FCO képződési entalpiák rendre $-179.9 \pm 3.8$ és $-179.1 \pm 2.9$ kJ mol ${ }^{-1}$-nek adódtak $0 \mathrm{~K}$ hőmérsékleten. Az izodezmikus reakciók fogalmát Pople és munkatársai vezették be 1970-ben. ${ }^{246,247}$ Definíció szerint egy izodezmikus reakció olyan átalakulás, ahol a reaktáns- és termékoldalon az azonos minőségú kötéstípusokból azonos mennyiségú fordul elő. Egy izogirikus folyamatban pedig az elektronpárok teljes száma változatlan marad. ${ }^{35}$ Francisco és Zhao ${ }^{240}$ a kétféle módon számított entalpia átlagát, $-179.5 \pm 3.3 \mathrm{~kJ} \mathrm{~mol}^{-1}$-et, fogadta el a $\Delta_{f} H_{0}^{\circ}(\mathrm{FCO})$ referenciaadataként.

A Haworth és csoportja ${ }^{232}$ által használt G3 módszer és annak módosított verziói az előzőhöz hasonló eredményeket szolgáltattak. A G3, G3[MP2(full)] és G3[MP4(SDQ)] számításokkal rendre $-178.7,-179.9$ és $-177.4 \mathrm{~kJ} \mathrm{~mol}^{-1}$-et kaptak a $\Delta_{f} H_{298}^{\circ}(\mathrm{FCO})$-ra. 
2006-os tanulmányukban Breidung és Thiel ${ }^{244}$ szintén foglalkoztak a karbonil-fluorid gyök termokémiájával. Számításaikban tulajdonképpen a CCSD(T) módszer robosztusságára alapoztak, de a skaláris relativisztikus hatások hozzájárulását szintén tanulmányozták. Mindazonáltal az elektronkorreláció kezelésekor a vegyérték-vegyérték korrelációt különválasztották a vegyértéktörzs valamint a törzs-törzs tagoktól és a $\operatorname{CCSD}(\mathrm{T})$ szint feletti gerjesztéseket már nem vették figyelembe. Három elméleti szinten összesen 5 reakcióra végeztek számításokat és az ebből előálló 15 adatot átlagolták. $-176.1 \pm 2.1$ és $-175.7 \pm 2.1 \mathrm{~kJ} \mathrm{~mol}^{-1}$-et kaptak a $\Delta_{f} H_{0}^{\circ}$ (FCO)-ra és a $\Delta_{f} H_{298}^{\circ}(\mathrm{FCO})$-ra.

Érdemes megjegyezni, hogy Knyazev és csoportjának ${ }^{239}$ 1997-es munkája óta nem született újabb kísérleti eredmény az FCO gyök termokémiai paramétereivel kapcsolatban. Azonban az experimentális adatok közötti jelentôs differencia, valamint az egyes értékekhez tartozó nagy hibahatár nyilvánvalóan szükségessé tenné a kísérletek revízióját. A HEAT-345(Q) modellel számított képződési entalpiánk, $\Delta_{f} H_{0}^{\circ}(\mathrm{FCO})=-177.2 \pm 0.9 \mathrm{~kJ} \mathrm{~mol}^{-1}$ és $\Delta_{f} H_{298}^{\circ}(\mathrm{FCO})=-176.7 \pm 0.9$ $\mathrm{kJ} \mathrm{mol}^{-1}$, konzekvens a korábbi számítási eredményekkel és a protokollunk nagyobb pontossága miatt ezeket az adatokat javasoljuk későbbi felhasználásra.

A karbonil-fluorid gyök standard képződési entrópiájára az NIST-JANAF adatbázis ${ }^{19}$ $S_{298}^{\circ}(\mathrm{FCO})=248.5 \mathrm{~J} \mathrm{~K}^{-1} \mathrm{~mol}^{-1}$-et javasol, melyet Milligan et al. ${ }^{248}$ spektroszkópiai tanulmányából származó rezgési frekvenciákból számítottak. A forgási hozzájárulás azonban, mely a teljes entrópiának több, mint egyharmadát adja, csupán becsült érték volt. A Burcat-féle adatbázis ${ }^{22}$ 249.0 $\mathrm{J} \mathrm{K}^{-1} \mathrm{~mol}^{-1}$-et fogad el az entrópiára, ami annyiban különbözik az NIST-JANAF értéktôl, hogy számításánál a kötésdeformációs normálrezgésre egy másik frekvenciaadatot ${ }^{249}$ használtak. Janoschek és Rossi242 G3MP2B3 számításai szintén $249.0 \mathrm{~J} \mathrm{~K}^{-1} \mathrm{~mol}^{-1}$-et ereményeztek. A HEAT-345(Q) protokoll az $S_{298}^{\circ}=248.8 \pm 1.5 \mathrm{~J} \mathrm{~K}^{-1} \mathrm{~mol}^{-1}$ éréket szolgáltatta az FCO entrópiájára, ami a számítás hibahatárán belül megegyezik a korábbi adatokkal. Mivel az általunk alkalmazott modell nyilvánvalóan pontosabb a G3MP2B3 módszernél és a kísérleti értékek csupán becsült spektroszkópiai adatokból származnak, ezért az általunk számított, $S_{298}^{\circ}(\mathrm{FCO})=248.8 \pm$ $\pm 1.5 \mathrm{~J} \mathrm{~K}^{-1} \mathrm{~mol}^{-1}$ standard moláris entrópiát javasoljuk új referenciaként.

\section{HFCO}

A formil-fluorid molekula, HFCO, összegyűjtött termokémiai adatai az 5.23. táblázatban olvashatók.

Nem található az irodalomban olyan kísérleti tanulmány, amely közvetlenül a HFCO képződési entalpiájának mérésével foglalkozik. Az NIST-JANAF táblázat ${ }^{19}$ a hibahatár nélküli $\Delta_{f} H_{0}^{\circ}(\mathrm{HFCO})$ $=-373.0 \mathrm{~kJ} \mathrm{~mol}^{-1}$ és $\Delta_{f} H_{298}^{\circ}(\mathrm{HFCO})=-376.6 \mathrm{~kJ} \mathrm{~mol}^{-1}$ becsült értékeket közli. Az adatokat a $\mathrm{HFCO}=\mathrm{CO}+\mathrm{F}+\mathrm{H}$ reakció entalpiájából számították ki, amit a $\mathrm{CH}_{2} \mathrm{O}=\mathrm{CO}+2 \mathrm{H}$ és a $\mathrm{CF}_{2} \mathrm{O}$ $=\mathrm{CO}+2 \mathrm{~F}$ folyamatok reakcióhőinek átlagával közelítettek. Így tulajdonképpen a $\Delta_{f} H_{0}^{\circ}(\mathrm{HFCO})$ mennyiség a $\Delta_{f} H_{0}^{\circ}\left(\mathrm{H}_{2} \mathrm{CO}\right)$ és a $\Delta_{f} H_{0}^{\circ}\left(\mathrm{F}_{2} \mathrm{CO}\right)$ átlagaként áll elő, ebből következően a $\mathrm{HFCO}$ képzôdési entalpiájához tartozó hiba jelentős lehet. 


\subsection{3. táblázat}

Az HFCO molekula irodalmi termodinamikai paraméterei. A képződési entalpiák kJ mol ${ }^{-1}$, az entrópiák $\mathrm{J} \mathrm{K}^{-1} \mathrm{~mol}^{-1}$ egységben szerepelnek.

\begin{tabular}{|c|c|c|c|}
\hline$\Delta_{f} H_{0}^{\circ}$ & $\Delta_{f} H_{298}^{\circ}$ & $S_{298}^{\circ}$ & Módszer és referencia ${ }^{a}$ \\
\hline \multicolumn{4}{|l|}{ Számítás } \\
\hline \multirow[t]{3}{*}{$-392.5 \pm 6.3$} & & & MP2 és MP4, 250 \\
\hline & $-383.3 \pm 7.1^{b}$ & & G2(MP2), 111 \\
\hline & $-382.3 \pm 4.4$ & & BAC-MP4, 241 \\
\hline \multirow[t]{8}{*}{-393.0} & -393.7 & & $\mathrm{G} 2,251$ \\
\hline & -384.9 & & G3,G3[MP2(full)], 232 \\
\hline & -383.7 & & G3[MP4(SDQ)], 232 \\
\hline & -389.2 & & BAC-MP2, 241 \\
\hline & -392.8 & & BAC-MP4, 241 \\
\hline & -385.2 & & AAC-G2, 241 \\
\hline & -385.5 & & AAC-G2MP2, 241 \\
\hline & -381.2 & & $\mathrm{CC}, 228$ \\
\hline
\end{tabular}

Újraértékelés

$-373.0$

$-376.6 \quad 246.5 \pm 0.8$

19

246.8

218

Jelen munka [HEAT-345(Q)]

$$
-378.8 \pm 1.2 \quad-382.5 \pm 1.2 \quad 246.5 \pm 1.5
$$

a A CC rövidítés coupled-cluster módszeren alapuló kompozit protokollra utal.

b A JPL adatbázis ${ }^{20}$ által elfogadott érték.

Ehhez hasonlóan jártak el Gurvich és munkatársai, ${ }^{218}$ akik a $\mathrm{HFCO}, \mathrm{CH}_{2} \mathrm{O}$ és $\mathrm{F}_{2} \mathrm{CO}$ rendszerek átlagos kötési energiáit jó közelítéssel azonosnak feltételezték: $\Delta_{f} H_{0}^{\circ}(\mathrm{HFCO})=-371 \pm 10$ $\mathrm{kJ} \mathrm{mol}^{-1}$-et kaptak.

Számos elméleti közlemény foglalkozik a HFCO termokémiájával. Zhao és Francisco ${ }^{250}$ MP2 és MP4 számításokkal $-392.5 \pm 6.3 \mathrm{~kJ} \mathrm{~mol}^{-1}$-es értéket közölt a $\Delta_{f} H_{0}^{\circ}(\mathrm{HFCO})$-ra, mely két izodezmikus reakciósémával ( $\mathrm{HFCO}+\mathrm{CH}_{4} \rightarrow \mathrm{H}_{2} \mathrm{CO}+\mathrm{CH}_{3} \mathrm{~F}$ és $\mathrm{HFCO}+\mathrm{HCO} \rightarrow \mathrm{H}_{2} \mathrm{CO}+\mathrm{FCO}$ ) kapott eredmény számtani közepe.

Schneider és Wallington ${ }^{111} \mathrm{G} 2(\mathrm{MP} 2)$ számításokat végzett a $2 \mathrm{HFCO} \rightarrow \mathrm{CH}_{2} \mathrm{O}+\mathrm{CF}_{2} \mathrm{O}$ izodezmikus reakcióra és $-383.3 \pm 7.1 \mathrm{~kJ} \mathrm{~mol}^{-1}$-et javasolt a $\Delta_{f} H_{298}^{\circ}(\mathrm{HFCO})$ mennyiségre. A JPL adatbázis $^{20}$ ezt az értéket adoptálta.

Zachariah és társai ${ }^{241}$ BAC-MP4 számításai $\Delta_{f} H_{298}^{\circ}(\mathrm{HFCO})=-382.3 \pm 4.4 \mathrm{~kJ} \mathrm{~mol}^{-1}$-et eredményeztek. Glukhovtsev és Bach ${ }^{251}$ vinil- és formil-halogenid származékok termokémiáját vizsgálta a G2 kompozit módszerrel atomizációs energia bázisán és -390.0 és 393.7 kJ mol${ }^{-1}$-et kapott a 0 és 298.15 K-es képződési entalpiára. 
BAC-MP2 és BAC-MP4 szintû számításokkal a 6-31G(d,p) bázissal Kondo és csoportja ${ }^{233}$ -389.2 és - 392.8 $\mathrm{kJ} \mathrm{mol}^{-1}$-es eredményt kapott 298.15 K-en. Az általuk kifejlesztett AAC-G2/6$31 \mathrm{G}(\mathrm{d}, \mathrm{p})$ és AAC-G2MP2/6-31G(d,p) módszerek -385.2 és $-385.5 \mathrm{~kJ} \mathrm{~mol}^{-1}$-et eredményeztek szintén 298.15 K hőmérsékleten.

Matus és munkatársai ${ }^{28}$ különböző korreláció-konzisztens bázisfüggvényekkel végzett CCSD(T) alapú számításokat CCSD(T)/aug-cc-pVTZ geometriákon. A CCSD(T)/CBS limitenergiákat kétféle extrapolációs séma eredményeinek átlagaként közelítették: (i) az aug-cc$\mathrm{pV}(\mathrm{D}, \mathrm{T}, \mathrm{Q}) \mathrm{Z}$ eredményekből extrapoláltak egy exponenciális formula szerint; és (ii) egy inverz harmadfokú összefüggés szerint aug-cc-pV(Q,5)Z eredményekből extrapolálva. Mindezek mellett MP2/aug-cc-pVTZ zéruspont rezgési energiákat, CCSD(T)/cc-pwCVTZ törzs-vegyérték korrelációs energiatagokat és CISD/cc-pVTZ skaláris relativisztikus korrekciókat is figyelembe vettek. Az atomizációs energia bázisán $\Delta_{f} H_{298}^{\circ}(\mathrm{HFCO})=-381.2 \mathrm{~kJ}$ mol${ }^{-1}$-et kaptak eredményül.

A HEAT-345(Q) modellel $\Delta_{f} H_{0}^{\circ}(\mathrm{HFCO})=-378.8 \pm 1.2 \mathrm{~kJ} \mathrm{~mol}^{-1}$ és $\Delta_{f} H_{298}^{\circ}(\mathrm{HFCO})=-$ $-382.5 \pm 1.2 \mathrm{~kJ} \mathrm{~mol}^{-1}$ adódott a képződési entalpiára. Egyrészt a kísérleti eredmények hiánya miatt, másrészt mivel az általunk használt protokoll a korábbiak közül a legpontosabb, ezért ezeket az értékeket javasoljuk új referenciaként.

Stratton és Nielsen ${ }^{252}$ valamint Morgan és munkatársainak ${ }^{253}$ spektroszkópiai méréseire hivatkozva az NIST-JANAF adatbázis ${ }^{19}$ az $S_{298}^{\circ}(\mathrm{HFCO})=246.5 \pm 0.8 \mathrm{~J} \mathrm{~K}^{-1} \mathrm{~mol}^{-1}$ entrópiaértéket javasolja. A JPL gyújtemény ${ }^{20}$ a Gurvich könyvében ${ }^{218}$ szereplő értéket, $246.8 \mathrm{~J} \mathrm{~K}^{-1} \mathrm{~mol}^{-1}$, fogadja el. A mi számításaink a NIST-JANAF táblázattal összhangban $S_{298}^{\circ}(\mathrm{HFCO})=246.5 \pm 1.5$ $\mathrm{JK}^{-1} \mathrm{~mol}^{-1}$-et eredményeztek a standard moláris entrópiára. Mivel az adatbázisban szereplő érték kisebb hibahatárral szerepel, ezért azt javasoljuk későbbi használatra.

\section{HCICO}

Kevés számú közlemény foglalkozik a formil-klorid, $\mathrm{HClCO}$, termokémiai tulajdonságaival (5.24. táblázat). Gurvich könyve a $\Delta_{f} H_{0}^{\circ}(\mathrm{HClCO})=-161.0 \pm 20.0 \mathrm{~kJ} \mathrm{~mol}^{-1}$-es értéket közli, feltételezve a $\mathrm{HClCO}, \mathrm{H}_{2} \mathrm{CO}$ és $\mathrm{Cl}_{2} \mathrm{CO}$ molekulák átlagos kötési energiáinak egyenlőségét.

Zhao és Francisco ${ }^{250}$ MP2/6-311G(2d,2p) geometriákon végzett MP4/6-311++G(2df,2p) számításokat és a Gurvich eredményénél jóval mélyebb $\Delta_{f} H_{0}^{\circ}(\mathrm{HClCO})=-190.4 \pm 6.3 \mathrm{~kJ} \mathrm{~mol}^{-1}$-es értéket közölték. Glukhovtsev és Bach ${ }^{251}$ G2 számításai Zhao és Francisco eredményét támasztják alá: $\Delta_{f} H_{0}^{\circ}(\mathrm{HClCO})=-189.5 \mathrm{~kJ} \mathrm{~mol}^{-1}$-et és $\Delta_{f} H_{298}^{\circ}(\mathrm{HClCO})=-192.7 \mathrm{~kJ} \mathrm{~mol}^{-1}$-et kaptak. Ezzel szemben Nguyen és Nguyen ${ }^{254}$ a valamivel magasabb $-180.6 \pm 8.0$ és $-183.9 \pm 8.0 \mathrm{~kJ} \mathrm{~mol}^{-1}$ es entalpiaértékeket közölte 0 illetve 298.15 K-en. Számításaikat CCSD(T)/6-311++G(3df,2p) szinten, MP2/6-31G(d,p) geometriákon végezték. 
5.24. táblázat

A HClCO molekula irodalmi termodinamikai paraméterei. A képződési entalpiák $\mathrm{kJ} \mathrm{mol}^{-1}$, az entrópiák $\mathrm{J} \mathrm{K}^{-1} \mathrm{~mol}^{-1}$ egységben szerepelnek.

\begin{tabular}{|c|c|c|c|}
\hline$\Delta_{f} H_{0}^{\circ}$ & $\Delta_{f} H_{298}^{\circ}$ & $S_{298}^{\circ}$ & Módszer és referencia \\
\hline \multicolumn{4}{|l|}{ Számítás } \\
\hline$-190.4 \pm 6.3$ & & & MP4//MP2, 250 \\
\hline-189.5 & -192.7 & & $\mathrm{G} 2,251$ \\
\hline$-180.6 \pm 8.0$ & $-183.9 \pm 8.0$ & & $\mathrm{CCSD}(\mathrm{T}) / / \mathrm{MP} 2,254$ \\
\hline \multicolumn{4}{|l|}{ Újraértékelés } \\
\hline$-161.0 \pm 20.0^{\mathrm{a}}$ & & $259.1 \pm 0.2$ & 218 \\
\hline \multicolumn{4}{|c|}{ Jelen munka [HEAT-345(Q)] } \\
\hline$-180.8 \pm 1.7$ & $-184.2 \pm 1.7$ & $258.7 \pm 1.5$ & \\
\hline
\end{tabular}

${ }^{a}$ A JPL adatbázis ${ }^{20}$ által elfogadott érték.

A HEAT-345(Q) modellel végzett számítások eredményei, $\Delta_{f} H_{0}^{\circ}(\mathrm{HClCO})=-180.8 \pm 1.7$ $\mathrm{kJ} \mathrm{mol}^{-1}$ és $\Delta_{f} H_{298}^{\circ}(\mathrm{HClCO})=-184.2 \pm 1.7 \mathrm{~kJ} \mathrm{~mol}^{-1}$, kiváló egyezést mutatnak Nguyen és Nguyen értékeivel. Mivel protokollunk pontoságga nyilvánvalóan meghaladja a korábbi számításokét, valamint a direkt kísérleti eredmények hiánya miatt a HEAT-345(Q) eredményeket javasoljuk későbbi felhasználásra.

A formil-klorid standard moláris entrópiájára a JPL adatbázis ${ }^{20}$ Gurvich $^{218}$ eredményét, $259.1 \pm 0.2 \mathrm{~J} \mathrm{~K}^{-1} \mathrm{~mol}^{-1}$, fogadja el, melyet Hisatsune és Heicklen ${ }^{255}$ spektroszkópiai, valamint Takeo és Matsamura ${ }^{256}$ mikrohullámú méréseiből származtattak. Modellünkkel $S_{298}^{\circ}(\mathrm{HClCO})=$ $258.7 \pm 1.5 \mathrm{~J} \mathrm{~K}^{-1} \mathrm{~mol}^{-1}$-et számítottunk. Referenciaként, annak kisebb hibahatára miatt, Gurvich $^{218}$ értékét javasoljuk.

\section{FCICO}

Szintén kevés termokémiai adat található az irodalomban a karbonil-fluorid-klorid rendszerre (5.25. táblázat).

Az NIST-JANAF gyújtemény ${ }^{19}$ a $\Delta_{f} H_{0}^{\circ}(\mathrm{FClCO})=-424.3 \pm 33.0 \mathrm{~kJ} \mathrm{~mol}^{-1}$ és a $\Delta_{f} H_{298}^{\circ}(\mathrm{FClCO})=-426.8 \pm 33.0 \mathrm{~kJ} \mathrm{~mol}^{-1}$ közelítő értékeket listázza. Az adatokat a $\mathrm{Cl}_{2} \mathrm{CO}$ és az $\mathrm{F}_{2} \mathrm{CO}$ megfelelő hőmérsékleten vett képződési entalipáinak átlagából számították. Gurvich könyve, ${ }^{218}$ hasonló feltételezés alapján, a $-427.0 \pm 20.0$ (0 K) és $-429.0 \pm 20.0$ (298.15 K) entalpiákat közli. A JPL adatbázis ${ }^{20}$ is ezeket az adatokat használja. A Burcat-féle lista ${ }^{22}$ G3B3 számítások alapján a valamivel magasabb $\Delta_{f} H_{298}^{\circ}(\mathrm{FClCO})=-412.5 \pm 8.0 \mathrm{~kJ} \mathrm{~mol}^{-1}$-es értéket javasolja. 


\subsection{5. táblázat}

Az FClCO molekula irodalmi termodinamikai paraméterei. A képződési entalpiák $\mathrm{kJ} \mathrm{mol}^{-1}$, az entrópiák $\mathrm{J} \mathrm{K}^{-1} \mathrm{~mol}^{-1}$ egységben szerepelnek.

\begin{tabular}{lccc}
\hline \hline \multicolumn{1}{c}{$\Delta_{f} H_{0}^{\circ}$} & $\Delta_{f} H_{298}^{\circ}$ & $S_{298}^{\circ}$ & Módszer és referencia \\
\hline \hline Számítás & & & \\
& $-412.5 \pm 8.0$ & 277.0 & $\mathrm{G} 3 \mathrm{~B} 3,22$ \\
\hline Újraértékelés & & & \\
$-424.3 \pm 33.0$ & $-426.8 \pm 33.0$ & 277.0 & 19 \\
$-427.0 \pm 20.0^{\mathrm{b}}$ & $-429.0 \pm 20.0^{\mathrm{a}}$ & $276.7 \pm 0.2^{\mathrm{a}}$ & 20,218 \\
\hline
\end{tabular}

Jelen munka [HEAT-345(Q)]

$$
-408.4 \pm 1.7 \quad-410.9 \pm 1.7 \quad 276.4 \pm 1.5
$$

a A JPL adatbázis ${ }^{20}$ által elfogadott érték.

Az általunk számított képződési entalpia, $\Delta_{f} H_{0}^{\circ}(\mathrm{FClCO})=-408.4 \pm 1.7 \mathrm{~kJ} \mathrm{~mol}^{-1}$ és $\Delta_{f} H_{298}^{\circ}(\mathrm{FClCO})=-410.9 \pm 1.7 \mathrm{~kJ} \mathrm{~mol}^{-1}$, jó egyezést mutat Burcat eredményével. Experimentális mérések valamint pontosabb protokollal számított adatok hiányában ezeket az értékeket javasoljuk új referenciaként.

A molekula standard moláris entrópiájának NIST-JANAF ${ }^{19}$ referenciaértéke 277.0 $\mathrm{J} \mathrm{K}^{-1} \mathrm{~mol}^{-1}$, mely Nielsen et al. ${ }^{257}$ spektroszkópiai méréséből és Lovell és csoportjának ${ }^{258}$ számításaiból származik. A JPL adatbázis ${ }^{20}$ Gurvich könyvére ${ }^{218}$ hivatkozva $S_{298}^{\circ}(\mathrm{FClCO})=$ $276.7 \pm 0.2 \mathrm{~J} \mathrm{~K}^{-1} \mathrm{~mol}^{-1}$ értéket közöl. Az entrópia számításához Gurvich a Mirri és csoportja 259 által mikrohullámú spektroszkópiával meghatározott forgási állandókat, valamint Nielsen és csoportjának ${ }^{257}$ spektroszkópiai vizsgálatából származó fundamentális frekvenciákat használta.

A HEAT-345(Q) eredmény, $S_{298}^{\circ}(\mathrm{FClCO})=276.4 \pm 1.5 \mathrm{~J} \mathrm{~K}^{-1} \mathrm{~mol}^{-1}$, kiválóan egyezik Gurvich számított értékével. Az utóbbihoz kisebb hibahatár tartozik, így azt, Gurvich $276.7 \pm 0.2$ $\mathrm{J} \mathrm{K}^{-1} \mathrm{~mol}^{-1}$-es értékét javasoljuk referenciaként.

\section{cisz-/transz-HOCO}

A továbbiakban HOCO jelölést használunk azokban az esetekben, amikor a hivatkozott irodalom nem különbözteti meg a cisz- és transz-izomereket. Ellenkezó esetben $c$-HOCO-val és $t$-HOCO-val rövidítjük a cisz- és transz-HOCO formulákat.

A HOCO izomerek irodalomból összegyújtött termokémiai adatait az 5.26. táblázat tartalmazza. 
5.26. táblázat

A HOCO gyök irodalmi termodinamikai paraméterei. A képződési entalpiák kJ mol${ }^{-1}$, az entrópiák $\mathrm{J} \mathrm{K}^{-1} \mathrm{~mol}^{-1}$ egységben szerepelnek.

\begin{tabular}{|c|c|c|c|}
\hline$\Delta_{f} H_{0}^{\circ}$ & $\Delta_{f} H_{298}^{\circ}$ & $S_{298}^{\circ}$ & Módszer és referencia ${ }^{\mathrm{a}}$ \\
\hline \multicolumn{4}{|l|}{ Kisérlet } \\
\hline & -259.4 & & 260 \\
\hline & -163.2 & & 261 \\
\hline & $-242.7 \pm 16.7$ & & 262 \\
\hline$-219.7 \pm 2.5$ & & & 263 \\
\hline \multirow[t]{3}{*}{$\geq-191.6 \pm 3.0$} & $\geq-194.6 \pm 3.0$ & & $t$-HOCO, 264 \\
\hline & $-196.7 \pm 8.4$ & 250.4 & 265 \\
\hline & $-192.5 \pm 12.6$ & & 266 \\
\hline$-205.0 \pm 10.0$ & & & 267 \\
\hline \multicolumn{4}{|l|}{ Számítás } \\
\hline & $-181.2 \pm 8.0^{\mathrm{b}}$ & & $t$-HOCO, G3/CBS-QB3, 20, 268 \\
\hline & $-173.2 \pm 8.0^{\mathrm{b}}$ & & $c$-HOCO, G3/CBS-QB3, 20, 268 \\
\hline & -193.0 & 251.6 & G2(MP2), 269 \\
\hline-182.5 & -185.4 & 252.0 & $t$-HOCO, G3MP2B3, 270 \\
\hline$-183.7 \pm 2.1$ & $-187.9 \pm 2.1$ & & $t$-HOCO, CC, 71 \\
\hline-182.6 & -185.6 & 251.5 & $t-\mathrm{HOCO}, \mathrm{W} 1 \mathrm{U}, 119$ \\
\hline-176.1 & -179.2 & 251.7 & $c-\mathrm{HOCO}, \mathrm{W} 1 \mathrm{U}, 119$ \\
\hline \multicolumn{4}{|l|}{ Újraértékelés } \\
\hline & $-181.3 \pm 2.3$ & & $t$-HOCO, 22 \\
\hline & $-176.3 \pm 3.9$ & & $c$-HOCO, 22 \\
\hline \multicolumn{4}{|c|}{ Jelen munka [HEAT-345(Q)] } \\
\hline$-181.3 \pm 1.2$ & $-184.5 \pm 1.2$ & $251.4 \pm 1.5$ & $t$-HOCO \\
\hline$-174.6 \pm 1.2$ & $-177.8 \pm 1.2$ & $251.7 \pm 1.5$ & $c-\mathrm{HOCO}$ \\
\hline
\end{tabular}

a A CC rövidítés coupled-cluster módszeren alapuló kompozit protokollra utal.

b A JPL adatbázis ${ }^{20}$ által elfogadott érték.

Az első kísérleti adat a HOCO 298 K-en vett képződési entalpiájára Back és Sehon ${ }^{260}$ 1960-as munkájából származik. A fenilecetsav termikus bomlását vizsgálták és az így mért $D_{298}^{\circ}\left(\mathrm{C}_{6} \mathrm{H}_{5} \mathrm{CH}_{2}-\mathrm{COOH}\right)=230.1 \mathrm{~kJ} \mathrm{~mol}^{-1}$-es kötésdisszociációs energiából $\Delta_{f} H_{298}^{\circ}(\mathrm{HOCO})=$

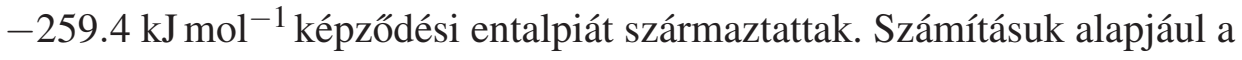

$$
\begin{array}{r}
\Delta_{f} H_{298}^{\circ}(\mathrm{HOCO})=\Delta_{f} H_{298}^{\circ}\left(\mathrm{C}_{6} \mathrm{H}_{5} \mathrm{CH}_{2} \mathrm{COOH}\right)+D_{298}^{\circ}\left(\mathrm{C}_{6} \mathrm{H}_{5} \mathrm{CH}_{2}-\mathrm{COOH}\right)- \\
-\Delta_{f} \mathrm{H}_{298}^{\circ}\left(\mathrm{C}_{6} \mathrm{H}_{5} \mathrm{CH}_{2}\right)
\end{array}
$$


termokémiai összefüggés szolgált, felhasználva a $\Delta_{f} H_{298}^{\circ}\left(\mathrm{C}_{6} \mathrm{H}_{5} \mathrm{CH}_{2} \mathrm{COOH}\right)=-313.8 \mathrm{~kJ} \mathrm{~mol}^{-1}$ és a $\Delta_{f} H_{298}^{\circ}\left(\mathrm{C}_{6} \mathrm{H}_{5} \mathrm{CH}_{2}\right)=175.7 \mathrm{~kJ} \mathrm{~mol}^{-1}$ adatokat. Egy évvel később Bernecker és Long ${ }^{261}$ a majdnem $100 \mathrm{~kJ} \mathrm{~mol}^{-1}$-el magasabb $-163.2 \mathrm{~kJ} \mathrm{~mol}^{-1}$-es értéket közölte a $\Delta_{f} H_{298}^{\circ}$ (HOCO)-ra. Ôk a $\mathrm{C}_{2} \mathrm{H}_{5}^{+}$ion küszöbpotenciálját (AP, appearance potential) mérték propionsav közegboól. Egy következő tömegspektrometriás tanulmányban Haney és Franklin ${ }^{262}$ a $\mathrm{CH}_{3}^{+}$ion AP-ját mérte ecetsavból, amiből $\Delta_{f} H_{298}^{\circ}(\mathrm{HOCO})=-242.7 \pm 16.7 \mathrm{~kJ} \mathrm{~mol}^{-1}$-et származtattak, alátámasztva Back és Sehon korábbi eredményét.

Ruscic és munkatársai ${ }^{263}$ PIMS módszerrel tanulmányozták a fluoratom reakcióját $\mathrm{HCOOH}$ val, DCOOH-val és HCOOD-vel. A HOCO adiabatikus IP-jét 8.482 \pm 0.012 eV-nak mérték. Kombinálva ezt az eredményt a $\Delta_{f} H_{0}^{\circ}\left(\mathrm{HOCO}^{+}\right)=599.1 \pm 2.1 \mathrm{~kJ} \mathrm{~mol}^{-1}$-es értékkel, ${ }^{271} \Delta_{f} H_{0}^{\circ}(\mathrm{HOCO})$ $=-219.7 \pm 2.5 \mathrm{~kJ} \mathrm{~mol}^{-1}$-et közöltek. Néhány évvel később Ruscic és Litorja ${ }^{264}$ revideálta a 263 referenciában közölt eredményeket és egy új felső korlátot állítottak fel a $t$-HOCO ionizációs energiájára: $\mathrm{EI}(t-\mathrm{HOCO}) \leq 8.195 \pm 0.022 \mathrm{eV}$. Ebből következően a $\Delta_{f} H_{0}^{\circ}(t-\mathrm{HOCO}) \geq-191.6 \pm 3.0$ $\mathrm{kJ} \mathrm{mol}^{-1}$ és a $\Delta_{f} H_{298}^{\circ}(t-\mathrm{HOCO}) \geq-194.6 \pm 3.0 \mathrm{~kJ} \mathrm{~mol}^{-1}$ alsó korlátok adódtak.

Schwarz és Dodson ${ }^{265}$ alkohol-gyökök redukciós potenciálját mérte $\mathrm{Tl}^{+}(\mathrm{aq}) / \mathrm{Tl}^{0}(\mathrm{aq})$ vizes közegú redoxrendszerben, amiből a gyökök képződési szabadenergiáját számították. Feltételezték, hogy az egyes gyökök oldódási szabadenergiája egyenlő a megfelelő alkoholéval, és így a gázfázisú $\Delta_{f} G^{\circ}$ és $\Delta_{f} H^{\circ}$ értékeket is becsülték. $-196.7 \pm 8.4 \mathrm{~kJ} \mathrm{~mol}^{-1}$-et közöltek a $\Delta_{f} H_{298}^{\circ}(\mathrm{HOCO})$-ra.

Fulle és csoportja ${ }^{267}$ a $\mathrm{HO}+\mathrm{CO} \rightleftharpoons \mathrm{HOCO} \rightarrow \mathrm{H}+\mathrm{CO}_{2}$ reakció kinetikai tulajdonságait vizsgálta. Méréseik alapján $-205.0 \pm 10.0 \mathrm{~kJ} \mathrm{~mol}^{-1}$-re becsülték a $\Delta_{f} H_{0}^{\circ}(\mathrm{HOCO})$ mennyiséget.

A gyök elméleti úton számított képződési entalpiaértékei között sokkal kisebb eltérések tapasztalhatók, az eredmények jóval konzekvensebbek, mint a kísérleti adatok. A JPL adatbázis ${ }^{20}$ is számított értékeket, a Duncan és Miller ${ }^{268}$ által közölt $\Delta_{f} H_{298}^{\circ}(t-\mathrm{HOCO})=-181.2 \pm 8.0 \mathrm{~kJ} \mathrm{~mol}^{-1}$ et és $\Delta_{f} H_{298}^{\circ}(c-\mathrm{HOCO})=-173.2 \pm 8.0 \mathrm{~kJ} \mathrm{~mol}^{-1}$-et javasolja referenciaként. Yu és társai ${ }^{269}$ G2(MP2) számításokat végzett hangyasavból és ecetsavból levezethető szabadgyökökre. Annak ellenére, hogy mind a cisz, mind a transz izomert vizsgálták, mindössze egyetlen hibahatár nélküli értéket, $\Delta_{f} H_{298}^{\circ}(\mathrm{HOCO})=-193.0 \mathrm{~kJ} \mathrm{~mol}^{-1}$, közöltek.

Janoschek és Rossi ${ }^{270}$ t-HOCO-ra végzett G3MP2B3 számításai - 182.5 és -185.4 kJ mol${ }^{-1}$ et eredményeztek 0 és $298 \mathrm{~K}$-en. Feller és csoportja ${ }^{71}$ szintén a transz izomerrel foglalkozott. $\operatorname{CCSD}(\mathrm{T})$ alapú kompozit protokolljukkal $\Delta_{f} H_{0}^{\circ}(t$-HOCO $)=-183.7 \pm 2.1 \mathrm{~kJ} \mathrm{~mol}^{-1}$ és $\Delta_{f} H_{298}^{\circ}(t$ $\mathrm{HOCO})=-187.9 \pm 2.1 \mathrm{~kJ} \mathrm{~mol}^{-1}$ entalpiákat számítottak.

Fabian és Janoschek ${ }^{119}$ a W1U modellel tanulmányozta az $\mathrm{OH}+\mathrm{CO} \rightarrow \mathrm{H}+\mathrm{CO}_{2}$ reakciót és a $\Delta_{f} H_{0}^{\circ}(t-\mathrm{HOCO})=-182.6 \mathrm{~kJ} \mathrm{~mol}^{-1}, \Delta_{f} H_{298}^{\circ}(t-\mathrm{HOCO})=-185.6 \mathrm{~kJ} \mathrm{~mol}^{-1}, \Delta_{f} H_{0}^{\circ}(c-\mathrm{HOCO})=$ $-176.1 \mathrm{~kJ} \mathrm{~mol}^{-1}$ és $\Delta_{f} H_{298}^{\circ}(c$-HOCO $)=-179.2 \mathrm{~kJ} \mathrm{~mol}^{-1}$ eredményeket közölték.

A HEAT-345(Q) protokoll a $t$-HOCO-ra a $-181.3 \pm 1.2(0 \mathrm{~K})$ és a $-184.5 \pm 1.2$ (298 $\mathrm{K})$, míg a $c$-HOCO-ra a $-174.6 \pm 1.2$ ( $0 \mathrm{~K}$ ) és a $-177.8 \pm 1.2$ (298 K) értékeket szolgáltatta $\mathrm{kJ} \mathrm{mol}^{-1}$ egységben. Mivel a számítási eredmények közül ez a legpontosabb, valamint a kísérleti adatok bizonytalansága miatt, a HEAT-345(Q) értékeket javasoljuk a képződési entalpiák új refe- 
renciájaként.

A HOCO gyök standard moláris entrópiájára vonatkozó egyetlen kísérleti adat, ${ }^{265,272}$ $S_{298}^{\circ}(\mathrm{HOCO})=250.4 \mathrm{~J} \mathrm{~K}^{-1} \mathrm{~mol}^{-1}$, a cisz és a transz izomer becsült geometriájából, ${ }^{273,274}$ valamint Milligan és Jacox ${ }^{273}$ rezgési frekvenciáiból származik. Yu et al. ${ }^{269} \mathrm{HF}-\mathrm{SCF} / 6-31 \mathrm{G}^{*}$ harmonikus rezgési frekvenciái $251.6 \mathrm{~J} \mathrm{~K}^{-1} \mathrm{~mol}^{-1}$-et eredményeztek. Janoschek és Rossi, ${ }^{270}$ B3LYP/631G* súrúségfunkcionál módszerrel optimalizált geometriájából és az ehhez tartozó harmonikus frekvenciákból, 252.0 J K ${ }^{-1} \mathrm{~mol}^{-1}$ entrópiaértéket számított. A 6-31G* Pople-bázis Dunning-féle cc-pVTZ-re történő cseréje (B3LYP/cc-pVTZ szint) az $S_{298}^{\circ}(t-\mathrm{HOCO})=251.5 \mathrm{~J} \mathrm{~K}^{-1} \mathrm{~mol}^{-1}$ és $S_{298}^{\circ}(c-\mathrm{HOCO})=251.7 \mathrm{~J} \mathrm{~K}^{-1} \mathrm{~mol}^{-1}$ értékekhez vezetett.

Protokollunkban alkalmazott CCSD(T)/cc-pVQZ számításokkal $251.4 \pm 1.5$ és $251.7 \pm 1.5$ $\mathrm{J} \mathrm{K}^{-1} \mathrm{~mol}^{-1}$ adódott a transz és a cisz izomerekre, melyeket két okból javasoltunk új referenciaként: (i) a kísérleti adat csupán becsült geometrián alapul; és (ii) a HEAT-345(Q) modell alkalmazza a legmagasabb elméleti szintet az entrópia kiszámításához.

\section{$\mathrm{NH}_{2} \mathrm{CO}$}

Csupán egyetlen adat található az irodalomban az $\mathrm{NH}_{2} \mathrm{CO}$ gyök képződési entalpiájára. ${ }^{20,275}$ Shapley és Bacskay a $\mathrm{CH}_{2} \mathrm{NO}$ gyök izomerizációs rakcióit tanulmányozva megállípította, hogy az izomerek közül termodinamikailag az $\mathrm{NH}_{2} \mathrm{CO}$ gyök a legstabilabb. Két izogirikus és egy izodezmikus reakcióra végzett $\mathrm{G} 2$ számítások alapján $\Delta_{f} H_{298}^{\circ}\left(\mathrm{NH}_{2} \mathrm{CO}\right)=-15.1 \pm 4.2 \mathrm{~kJ} \mathrm{~mol}^{-1}$-et közöltek. ${ }^{275}$ Nyilvánvaló, hogy az általunk használt protokoll pontossága felülmúlja a G2 módszerét, ezért a HEAT-345(Q) eredményeket, $\Delta_{f} H_{0}^{\circ}\left(\mathrm{NH}_{2} \mathrm{CO}\right)=-7.2 \pm 1.5 \mathrm{~kJ} \mathrm{~mol}^{-1}$ és $\Delta_{f} H_{298}^{\circ}\left(\mathrm{NH}_{2} \mathrm{CO}\right)=-$ $-13.1 \pm 1.5 \mathrm{~kJ} \mathrm{~mol}^{-1}$, javasoljuk késôbbi felhasználásra. Mivel egyetlen kísérleti vagy számítási referenciaadat sem áll rendelkezésre a gyök standard moláris entrópiájára, ezért ismét az általunk számított értéket, $S_{298}^{\circ}\left(\mathrm{NH}_{2} \mathrm{CO}\right)=256.5 \pm 1.5 \mathrm{~J} \mathrm{~K}^{-1} \mathrm{~mol}^{-1}$, javasoljuk új referenciaként.

\subsubsection{Kéntartalmú származékok}

\section{HSO és HOS}

A HSO gyök irodalmi termokémiai adatait az 5.27., míg a HOS gyökét az 5.28. táblázatban gyújtöttem össze.

Molekulanyaláb tömegspektroszkópiai méréseik alapján Davidson és munkatársai ${ }^{276}-5.6 \pm$

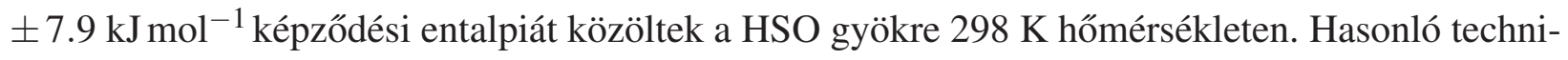
kával vizsgálva az $\mathrm{O}\left({ }^{3} \mathrm{P}\right)+\mathrm{H}_{2} \mathrm{~S} \rightarrow \mathrm{HSO}+\mathrm{H}$ reakciót, Balucani és munkatársai ${ }^{122}$ a $\Delta_{f} H_{0}^{\circ}(\mathrm{HSO})$ $=-3.8 \pm 2.9 \mathrm{~kJ} \mathrm{~mol}^{-1}$-es eredményhez jutott. A JPL adatbázis ${ }^{20}$ mindkét kísérleti munkára hivatkozva $\Delta_{f} H_{298}^{\circ}(\mathrm{HSO})=-6.1 \pm 2.9 \mathrm{~kJ} \mathrm{~mol}^{-1}$-et javasol. Az elméleti úton számított képződési entalpiák ezektől jelentősen eltérnek. Goumri és csoportja ${ }^{277}$ a G2 módszerrel $\Delta_{f} H_{0}^{\circ}(\mathrm{HSO})=-$ $-19.9 \mathrm{~kJ} \mathrm{~mol}^{-1}$-et kapott. Xantheas és Dunning MRCI számításai ${ }^{278}-22.6 \pm 5.4 \mathrm{~kJ} \mathrm{~mol}^{-1}$-et eredményeztek $0 \mathrm{~K}$-en. Később CAS-SCF szinten a HOS gyökre is végeztek számításokat ${ }^{279}$ és 
$\Delta_{f} H_{298}^{\circ}(\mathrm{HSO})=-25.5 \pm 5.4 \mathrm{~kJ} \mathrm{~mol}^{-1}$ valamint $\Delta_{f} H_{298}^{\circ}(\mathrm{HOS})=-2.9 \pm 5.4 \mathrm{~kJ} \mathrm{~mol}^{-1}$ értékeket közöltek a két rendszerre. Grant és társai ${ }^{123} \operatorname{CCSD}(\mathrm{T})$ szintet alkalmaztak és a $\Delta_{f} H_{0}^{\circ}(\mathrm{HSO})=$ $-21.8 \pm 4.2 \mathrm{~kJ} \mathrm{~mol}^{-1}$ valamint a $\Delta_{f} H_{298}^{\circ}(\mathrm{HSO})=-24.7 \pm 4.2 \mathrm{~kJ} \mathrm{~mol}^{-1}$ értékeket közölték.

\subsection{7. táblázat}

A HSO gyök irodalmi termodinamikai paraméterei. A képződési entalpiák $\mathrm{kJ} \mathrm{mol}^{-1}$, az entrópiák $\mathrm{J} \mathrm{K}^{-1} \mathrm{~mol}^{-1}$ egységben szerepelnek.

\begin{tabular}{|c|c|c|c|}
\hline$\Delta_{f} H_{0}^{\circ}$ & $\Delta_{f} H_{298}^{\circ}$ & $S_{298}^{\circ}$ & Módszer és referencia \\
\hline \multicolumn{4}{|l|}{ Számítás } \\
\hline$-21.8 \pm 4.2$ & $-27.4 \pm 4.2$ & & $\operatorname{CCSD}(\mathrm{T}), 123$ \\
\hline$-22.6 \pm 5.4$ & & & MRCI, 278 \\
\hline & $-25.5 \pm 5.4$ & & CASSCF, 279 \\
\hline & 5.9 & & CCSDT, 280 \\
\hline & -19.9 & & $\mathrm{G} 2,277$ \\
\hline
\end{tabular}

Jelen munka [HEAT-345+d $(Q)]$

$-19.6 \pm 2.3 \quad-22.6 \pm 2.3 \quad 241.4 \pm 1.5$

5.28. táblázat

A HOS gyök irodalmi termodinamikai paraméterei

\begin{tabular}{cccc}
\hline \hline$\Delta_{f} H_{0}^{\circ}$ & $\Delta_{f} H_{298}^{\circ}$ & $S_{298}^{\circ}$ & Módszer és referencia \\
\hline \hline Kísérlet & & & \\
$-3.8 \pm 2.9$ & $-6.1 \pm 2.9$ & & $20,122^{\mathrm{a}}$ \\
& $-5.6 \pm 7.9$ & $276^{\mathrm{a}}$ \\
\hline
\end{tabular}

Számítás

$-2.9 \pm 5.4 \quad$ CASSCF, 279

Jelen munka [HEAT-345+d(Q)]

$-2.4 \pm 2.3 \quad-5.3 \pm 2.3 \quad 240.0 \pm 1.5$

a A hivatkozott referencia a HSO gyök képződését feltételezi a kísérletekben.

A kísérletileg mért és a számított értékek közötti ellentmondás feloldása érdekében jelen munkában szintén mindkét gyök képződési entalpiáját számítottuk. Eredményeink szerint a HOS gyök HEAT-345+d(Q) szinten számított entalpiaértékei, $-2.5 \pm 2.3$ és $-5.3 \pm 2.3 \mathrm{~kJ} \mathrm{~mol}^{-1} 0$ és $298 \mathrm{~K}$ en, remek egyezést mutatnak azokkal az experimentális adatokkal, melyeket a HSO-ra közöltek ezeken a hőmérsékleteken. Ezen egyezés alapján joggal élhetünk a feltételezéssel, miszerint az említett kísérletekben HSO helyett a szerkezeti izomer HOS gyök képződött.

A $\Delta_{f} H_{0}^{\circ}(\mathrm{HSO}), \Delta_{f} H_{298}^{\circ}(\mathrm{HSO}), \Delta_{f} H_{0}^{\circ}(\mathrm{HOS})$ és $\Delta_{f} H_{298}^{\circ}(\mathrm{HOS})$ mennyiségekre az általunk alkalmazott HEAT-345 $+d(\mathrm{Q})$ modell szolgáltatta a legmegbízhatóbb eredményeket, melyek rendre $-19.6 \pm 2.3,-22.6 \pm 2.3,-2.4 \pm 2.3$ és $-5.3 \pm 2.3 \mathrm{~kJ} \mathrm{~mol}^{-1}$-nek adódtak. Mindezek mellett, munkánkban elsőként teszünk javaslatot mind a HSO, mind a HOS gyökök standard moláris 
entrópiájára. Számításaink $S_{298}^{\circ}(\mathrm{HSO})=241.4 \pm 1.5 \mathrm{~J} \mathrm{~K}^{-1} \mathrm{~mol}^{-1}$ és $S_{298}^{\circ}(\mathrm{HOS})=240.0 \pm 1.5$ $\mathrm{J} \mathrm{K}^{-1} \mathrm{~mol}^{-1}$ értékeket eredményezték.

\section{$\mathrm{HOSO}_{2}$}

A $\mathrm{HOSO}_{2}$ gyök termodinamikai paramétereinek néhány reprezentatív értékét az 5.29. táblázatba gyújtöttem össze.

Gleason és Howard ${ }^{124}$ a $\mathrm{HOSO}_{2}+\mathrm{O}_{2} \rightarrow \mathrm{HO}_{2}+\mathrm{SO}_{3}$ folyamat sebességi együtthatójának hőmérsékletfüggését vizsgálta alacsony nyomású áramlásos reaktorban. $\mathrm{A} \Delta_{f} \mathrm{H}_{298}^{\circ}\left(\mathrm{HOSO}_{2}\right)$ mennyiségre egy alsó korlátot, szám szerint $\geq-395.4 \mathrm{~kJ} \mathrm{~mol}^{-1}$-et adtak meg. Blitz és munkatársai ${ }^{281}$ $\Delta_{f} H_{298}^{\circ}\left(\mathrm{HOSO}_{2}\right)=-373.0 \pm 6.0 \mathrm{~kJ} \mathrm{~mol}^{-1}$ képződési entalpiát számított az $\mathrm{OH}+\mathrm{SO}_{2} \rightleftharpoons \mathrm{HOSO}_{2}$ folyamat reakcióhőjének fluoreszcens spektroszkópiai méréséből.

Li és $M c K e e^{282}$ a Gleason és Howard által vizsgált reakcióra végzett G2 számításokat és a $-364.8 \mathrm{~kJ} \mathrm{~mol}^{-1}$-es eredményt közölte a $\Delta_{f} H_{298}^{\circ}\left(\mathrm{HOSO}_{2}\right)$-re. B3LYP/aug-cc-pV(T+d)Z szintû egyensúlyi geometriákon alapuló G3X módszerrel végzett számításaival Somnitz ${ }^{283}$ $\Delta_{f} H_{0}^{\circ}\left(\mathrm{HOSO}_{2}\right)=-360.8 \mathrm{~kJ} \mathrm{~mol}^{-1}$ és $\Delta_{f} H_{298}^{\circ}\left(\mathrm{HOSO}_{2}\right)=-368.8 \mathrm{~kJ} \mathrm{~mol}^{-1}$ értékeket kapott. Klopper és csoportja ${ }^{125}$ egy csatolt-klaszter alapokon nyugvó kompozit modellt használt a gyök képzôdési entalpiájának számításához és a $-366.6 \pm 2.5$ (0 K) és a $-374.1 \pm 3.0 \mathrm{~kJ} \mathrm{~mol}^{-1}$ (298 K) értékeket közölte.

Az általunk kidolgozott modellel elért legpontosabb entalpiaértékek, $-367.5 \pm 4.4$ és $-375.7 \pm$ $\pm 4.4 \mathrm{~kJ} \mathrm{~mol}^{-1} 0$ és $298 \mathrm{~K}$-en, jó egyezést mutatnak mind a Klopper és csoportja által számított, ${ }^{125}$ mind a Blitz és társai által kísérletileg meghatározott ${ }^{281}$ adatokkal. Mivel a legpontosabb eredmények elméleti számításokból származnak, nevezetesen a Klopper-féle, valamint a jelen tanulmnyból, ezért érdemes röviden összehasonlítani a kétféle kompozit modellt. A Klopper-féle modell a $\operatorname{CCSD}(\mathrm{T})$ szint feletti ún. magasabb rendû korrelációs hatásokat nem veszi figyelembe, viszont a törzselektronok korrelációját nem választja külön a vegyértékelektronokétól. Az utóbbi szétvá-

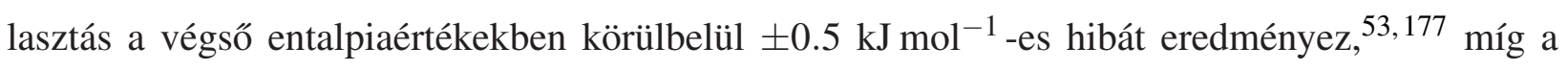
$\Delta E_{\mathrm{CCSDT}(\mathrm{Q})}$ energiatag számításaink szerint $2.3 \pm 1.3 \mathrm{~kJ} \mathrm{~mol}^{-1}$-el járul hozzá a $\Delta_{f} H_{T}^{\circ}\left(\mathrm{HOSO}_{2}\right)$ mennyiséghez. Jelentős különbség van a két modell között a CCSD(T) hozzájárulás számításában is : Klopperék két- és háromszoros- $\zeta$ minőségű báziskészleteket használtak, jelen munkában pedig négy- és ötszörös- $\zeta$ bázisokkal közelítettük a $\Delta E_{\mathrm{CCSD}(\mathrm{T})}^{\infty}$ tagot. Jól ismert tény, hogy nem elegendő sem a kétszeres-, sem a háromszoros- $\zeta$ minőség a hozzájárulás elegendően pontos számításához: a kis kardinális szám alkalmazása a végeredményekben akár több $\mathrm{kJ} \mathrm{mol}^{-1}$-es hibát is okozhat. Mindezek alapján nyilvánvaló, hogy a jelen munkában használt modell pontosabb, és így a Klopper és csoportja által közölt hibahatárok ( \pm 2.5 és $\pm 3.0 \mathrm{~kJ} \mathrm{~mol}^{-1} 0$ és $298 \mathrm{~K}$-en) kissé optimisztikus becslésnek tekinthetôk.

A standard moláris entrópiára modellünk 294.1 $\pm 1.5 \mathrm{~J} \mathrm{~K}^{-1} \mathrm{~mol}^{-1}$-et eredményezett. A Burcatféle adatbázisban, ${ }^{22}$ ugyan hibahatár nélkül, de pontosan ezzel megegyezó érték szerepel. Patrick és Golden adata, $280.8 \mathrm{~J} \mathrm{~K}^{-1} \mathrm{~mol}^{-1},{ }^{284}$ azonban jelentősen különbözik ezektől. A Patrick és Gol- 
den entrópiájának számításához használt frekvenciák és geometriák forrása, valamint azok pontossága egyaránt ismeretlen. Azon túlmenően, hogy az érték hibahatár nélkül szerepel, a kisfrekvenciájú rezgést harmonikus oszcillátorként kezelték. A Burcat-féle gyújteményben listázott entrópia BAC-MP4 számításokból származik, és ott már az említett kisfrekvenciájú rezgést (helyesen) gátolt rotációs mozgásként tárgyalták. Új referenciaként az általunk számított $S_{298}^{\circ}=294.1 \pm 1.5$ $\mathrm{J} \mathrm{K}^{-1} \mathrm{~mol}^{-1}$-es értéket javasoljuk, mivel egyrészt modellünk pontossága felülmúlja a BAC-MP4ét, másrészt entrópiánk jól definiált hibahatárral együtt szerepel.

\subsection{9. táblázat}

A $\mathrm{HOSO}_{2}$ gyök irodalmi termodinamikai paraméterei. A képződési entalpiák $\mathrm{kJ} \mathrm{mol}^{-1}$, az entrópiák $\mathrm{J} \mathrm{K}^{-1} \mathrm{~mol}^{-1}$ egységben szerepelnek.

\begin{tabular}{lccc}
\hline \hline \multicolumn{1}{c}{$\Delta_{f} H_{0}^{\circ}$} & $\Delta_{f} H_{298}^{\circ}$ & $S_{298}^{\circ}$ & Módszer és referencia $^{\mathrm{a}}$ \\
\hline \hline Kisérlet & & & \\
& $-373.0 \pm 6.0$ & & 281 \\
& $-385.0 \pm 10.0$ & & 286 \\
& -385.4 & 294.1 & 22,285 \\
& $\geq-395.4$ & 280.8 & 124,284 \\
\hline
\end{tabular}

\begin{tabular}{rrc}
\hline \multicolumn{1}{l}{ Számítás } & \\
$-366.6 \pm 2.5$ & $-374.1 \pm 3.0$ & $\mathrm{CC}, 125$ \\
-360.8 & -368.8 & $\mathrm{G} 3 \mathrm{X}, 283$ \\
& -364.8 & $\mathrm{G} 2,282$
\end{tabular}

Jelen munka [HEAT-345+d $(Q)]$

$$
-367.5 \pm 4.4 \quad-375.7 \pm 4.4 \quad 294.1 \pm 1.5
$$

a A CC rövidítés coupled-cluster módszeren alapuló kompozit protokollra utal.

\section{Cisz- és transz-HSNO}

A HSNO molekulának ugyan kétféle izomere létezik, ${ }^{287}$ cisz-és transz-HSNO, a termokémiai vonatkozású szakirodalom nem tesz különbséget ezek között. Az RSNO általános képlettel leírható S-nitrozotiolok cisz és transz konformereinek létezését krisztallográfiai és NMR-spektroszkópiai mérések eredményei egyértelmúen alátámasztják. (287. referencia és annak hivatkozott irodalma). NMR-vizsgálatok alapján továbbá igazolták, hogy a két izomer közel izoenergetikus, azonban relatíve magas, $46.0 \mathrm{~kJ} \mathrm{~mol}^{-1}$-es energiagát választja el őket.

Timerghazin és társai ${ }^{287}$ egy extrapolált CCSD(T) energiákon alapuló kompozit modellel vizsgálta a kérdéses HSNO izomereket. Elsősorban a transz konformer S-N kötésének erősségét tanulmányozták, de emellett a két rotamer relatív energiáját szintén számították. Legpontosabb eredményük szerint a cisz és a transz izomerek közötti energiakülönbség mindössze $3.1 \mathrm{~kJ} \mathrm{~mol}^{-1}$, jó közelítéssel izoenergetikusnak tekinthetôk. Mindazonáltal az őket elválasztó eneriagát nagyságára 
nem történtek becslések.

A fent leírtakon túlmenően, kevés adat található az irodalomban az izomerek termokémiai paramétereire (5.30. táblázat). A HS $+\mathrm{NO}+\mathrm{M} \rightarrow \mathrm{HSNO}+\mathrm{M}$ reakció lézerindukált fluoreszcens

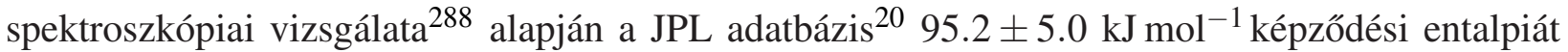
listáz a transz izomerre 298 K-en. A reakcióban M az ún. „harmadik testet” jelöli, ami egy kinetikailag harmadrendú asszociációs folyamat során a felszabaduló többletenergiát elnyeli. ${ }^{126}$ Egy könyvfejezetében Heynes és Wine $28694.0 \pm 20.0$ kJ mol${ }^{-1}$ képződési entalpiát javasol szintén a transz izomerre.

Az egyetlen elméleti számításokon alapuló közleményben Nguyen és társai ${ }^{289}$ CCSD(T)/6311++G(3df,2p) szinten számította a HSNO protonaffinitását és képződési entalpiáját 298 K-en, melyek közül az utóbbira $112.0 \pm 8.0 \mathrm{~kJ} \mathrm{~mol}^{-1}$ adódott. A szerzők nem tesznek említést a HSNO két izomerérôl.

\subsection{0. táblázat}

A HSNO izomerek irodalmi termodinamikai paraméterei. A képződési entalpiák $\mathrm{kJ} \mathrm{mol}^{-1}$, az entrópiák $\mathrm{J} \mathrm{K}^{-1} \mathrm{~mol}^{-1}$ egységben

szerepelnek.

\begin{tabular}{cccc}
\hline \hline$\Delta_{f} H_{0}^{\circ}$ & $\Delta_{f} H_{298}^{\circ}$ & $S_{298}^{\circ}$ & Módszer és referencia \\
\hline \multicolumn{4}{c}{ transz-HSNO }
\end{tabular}

Kísérlet

\begin{tabular}{lcc} 
& $95.2 \pm 5.0$ & 20,288 \\
& $94.0 \pm 20.0$ & 286 \\
\hline Számítás & & \\
\multicolumn{2}{c}{$112.0 \pm 8.0$} & $\mathrm{CCSD}(\mathrm{T}), 289^{\mathrm{a}}$ \\
\hline \multicolumn{2}{c}{ Jelen munka $[$ HEAT-345+d $(Q)]$} & \\
$112.4 \pm 2.7 \quad 107.3 \pm 2.7 \quad 266.4 \pm 1.5$ & \\
\hline \hline
\end{tabular}

Jelen munka [HEAT-345+d $(Q)]$

$115.8 \pm 2.7 \quad 110.7 \pm 2.7 \quad 266.1 \pm 1.5$

a A kérdéses referenciában Nguyen et al. nem különbözeti meg a cisz- és transzHSNO-t.

A $\mathrm{CH}_{3} \mathrm{SH}$ és a $\mathrm{H}_{2} \mathrm{~S}$, valamint a megfelelő oxigéntartalmú analógok, a $\mathrm{CH}_{3} \mathrm{OH}$ és a $\mathrm{H}_{2} \mathrm{O}$ kötéserősségeinek összehasonlítása alapján Black és társai ${ }^{288}$ a HS-NO kötés erősségét $\left[D_{298}^{\circ}(\mathrm{HS}-\mathrm{NO})\right] 99.8$ és $137.5 \mathrm{~kJ} \mathrm{~mol}^{-1}$ közé becsülte. Ennek ellenére számításaikban a $D_{298}^{\circ}(\mathrm{HS}-\mathrm{NO})=139.0 \mathrm{~kJ} \mathrm{~mol}^{-1}$ disszociációs entalpiát használták, mivel így jobb egyezést kaptak a $\mathrm{HS}+\mathrm{NO}+\mathrm{He} \rightarrow \mathrm{HSNO}+\mathrm{He}$ reakció $k_{0}$ értékének kísérletileg mért hőmérsékletfüggésével. Mindemellett leszögezték, hogy ,,az asszociációs reakciók kinetikai tanulmányozása nem tartozik azon módszerek közé, melyek megbízható termodinamikai adatokat szolgáltatnak.” 
Ha a 99.8 és $137.5 \mathrm{~kJ} \mathrm{~mol}^{-1}$ határértékek számtani közepét, $118.7 \pm 18.9 \mathrm{~kJ} \mathrm{~mol}^{-1}$-et fogadjuk el $D_{298}^{\circ}(\mathrm{HS}-\mathrm{NO})$ értékének, akkor $114.4 \pm 19.5 \mathrm{~kJ} \mathrm{~mol}^{-1}$ származtatható a $\Delta_{f} H_{298}^{\circ}$ (transz-HSNO) mennyiségre a következő összefüggés felhasználásával:

$$
\Delta_{f} H_{298}^{\circ}(\text { transz-HSNO })=\Delta_{f} H_{298}^{\circ}(\mathrm{HS})+\Delta_{f} H_{298}^{\circ} \mathrm{NO}-D_{298}^{\circ}(\mathrm{HS}-\mathrm{NO})
$$

ahol $\Delta_{f} H_{298}^{\circ}(\mathrm{HS})=141.9 \pm 0.5 \mathrm{~kJ} \mathrm{~mol}^{-1}$ (ref. 290) és $\Delta_{f} H_{298}^{\circ}(\mathrm{NO})=91.1 \pm 0.1 \mathrm{~kJ} \mathrm{~mol}^{-1} . \mathrm{Az}$ így kapott eredmény jól egyezik az általunk számított $112.4 \pm 2.7$ és $107.3 \pm 2.7 \mathrm{~kJ} \mathrm{~mol}^{-1}$-es 0 és 298 K-es értékkel. Az $S_{298}^{\circ}$ (transz-HSNO) mennyiségre protokollunk $266.4 \pm 1.5 \mathrm{~J} \mathrm{~K}^{-1} \mathrm{~mol}^{-1}$-et eredményezett.

Érdemes megjegyezni, hogy jelen munka az első, mely jól definiált hibával rendelkező képződési entalpia és standard moláris entrópiaadatot közöl a cisz-HSNO molekulára (5.30. táblázat utolsó sora). Ezen túlmenôen mind a cisz, mind a transz izomerre a jelen dolgozatban alkalmazott HEAT-345+d(Q) szolgáltatta a legmegbízhatóbb és legkisebb hibával rendelkező entalpiaadatokat, így ezek referenciaként történő alkalmazása javasolt.

\section{SH}

Dolgozatomban vizsgált kéntartalmú rendszerek közül a merkapto gyök, SH, rendelkezik a legkiterjedtebb irodalmi háttérrel. Elméleti úton származtatott termodinamikai paraméterei ugyan pontosak és következetesek, azonban a szintén nagy pontosságú kísérleti eredményektől való eltérésük nagyobb, mint azt az egyes adatokhoz tartozó hibahatárok megengednének. Ezen diszkrepancia miatt a gyök nem került bele a HEAT-345+d(Q) protokoll tesztkészletébe, sokkal helyénvalóbbnak találtam egy külön részfejezetben bemutatni és röviden diszkuttálni a kérdéses adatokat, melyeket az 5.31. táblázatban foglaltam össze.

Az NIST-JANAF adatbázis $136.5 \pm 5.0$ és $139.3 \pm 5.0 \mathrm{~kJ} \mathrm{~mol}^{-1}$-et listáz a $\Delta_{f} H_{0}^{\circ}(\mathrm{SH})$ és $\Delta_{f} H_{298}^{\circ}(\mathrm{SH})$ mennyiségekre. Az értékeket egyrészt Dibeler és Liston fotoionizációs eredményeiből, ${ }^{291}$ másrészt az SH gyök ionizációs energiájának Morrrow-féle értékéből ${ }^{292}$ származtatták. Traeger PIMS mérései ${ }^{293} \Delta_{f} H_{298}^{\circ}(\mathrm{SH})=138.6 \pm 0.4 \mathrm{~kJ} \mathrm{~mol}^{-1}$-et erdményeztek. A szerzô továbbá leszögezi, hogy az $\mathrm{SH}^{+}$kation küszöbenergiájának egy pontosabb értékével (ref. 294) a 298 K-es NIST-JANAF érték $142.0 \pm 3.0 \mathrm{~kJ} \mathrm{~mol}^{-1}$-re módosítható.

Berkowitz és csoportja ${ }^{295}$ a kénatom kötési energiájának erôsségét mérte különböző kémiai rendszerekben, háromféle kísérleti technikával: kinetikai vizsgálatok, gázfázisú savassági tulajdonságok mérése, valamint PIMS. $143.3 \pm 3.0 \mathrm{~kJ} \mathrm{~mol}^{-1}$-et javasoltak a $\Delta_{f} H_{298}^{\circ}(\mathrm{SH})$ mennyiségre.

Nourbakhsh et al. ${ }^{296} \mathrm{a} \mathrm{CH}_{3} \mathrm{SH}$ PIMS vizsgálata során a $\mathrm{CH}_{3}$ és SH fragmentumok repülési idő analízisével $\Delta_{f} H_{298}^{\circ}(\mathrm{SH})=142.3 \pm 6.3 \mathrm{~kJ} \mathrm{~mol}^{-1}$-et kapott.

Végül Nicovich és társai ${ }^{297}$ a $\mathrm{Br}+\mathrm{H}_{2} \mathrm{~S} \rightarrow \mathrm{SH}+\mathrm{HBr}$ reakció kinetikai vizsgálata alapján $142.5 \pm 3.0$ és $143.0 \pm 2.8 \mathrm{~kJ} \mathrm{~mol}^{-1}$ entalpiaértékeket adott meg 0 és $298 \mathrm{~K}$-en. 
5.31. táblázat

Az SH gyök irodalmi termodinamikai paraméterei. A képződési entalpiák $\mathrm{kJ} \mathrm{mol}^{-1}$, az entrópiák $\mathrm{JK}^{-1} \mathrm{~mol}^{-1}$ egységben szerepelnek.

\begin{tabular}{cccc}
\hline \hline$\Delta_{f} H_{0}^{\circ}$ & $\Delta_{f} H_{298}^{\circ}$ & $S_{298}^{\circ}$ & Módszer és referencia $^{a}$ \\
\hline \hline Kísérlet & & \\
$138.6 \pm 0.4$ & & 293 \\
$142.5 \pm 3.0$ & $143.0 \pm 2.8$ & 297 \\
& $143.0 \pm 3.0$ & 295 \\
$141.8 \pm 6.3$ & $142.4 \pm 6.3$ & 296 \\
\hline
\end{tabular}

\begin{tabular}{|c|c|c|c|}
\hline \multicolumn{4}{|l|}{ Számítás } \\
\hline \multirow[t]{2}{*}{$141.2 \pm 0.5$} & $141.9 \pm 0.5$ & & CC, 298 \\
\hline & $141.0 \pm 0.8$ & & CC, 77 \\
\hline $142.6 \pm 0.8$ & $143.1 \pm 0.8$ & & CC, 299 \\
\hline \multirow[t]{4}{*}{137.5} & 137.6 & 197.9 & G3MP2B3, 270 \\
\hline & 141.0 & & $\mathrm{G} 3,32$ \\
\hline & 138.0 & & G3(MP2), 300 \\
\hline & 140.6 & & $\mathrm{~W} 2,301$ \\
\hline \multicolumn{4}{|c|}{ Újraértékelés } \\
\hline $136.5 \pm 5.0$ & $139.3 \pm 5.0$ & $195.6 \pm 0.0$ & 19 \\
\hline \multicolumn{4}{|c|}{ Jelen munka $[H E A T-345+\mathrm{d}(Q)]$} \\
\hline $142.8 \pm 1.9$ & $143.4 \pm 1.9$ & $195.4 \pm 1.5$ & \\
\hline
\end{tabular}

Az elméleti módszerek közül a G3, G3(MP2) és a G3MP2B3 modellek $141.0,{ }^{32} 138.0^{300}$ és $137.6 \mathrm{~kJ} \mathrm{~mol}^{-1}$-es ${ }^{270}$ képződési entalpiákat szolgáltattak 298 K-en, míg az ezeknél valamivel pontosabb Martin-féle W2 protokollal ${ }^{48} \Delta_{f} H_{298}^{\circ}(\mathrm{SH})=140.6 \mathrm{~kJ} \mathrm{~mol}^{-1}$ számítható.

Peebles és Marshall ${ }^{299}$ szintén egy kompozit modellt alkalmazott, mely FC-CCSD(T)/CBS energiákon alapult. Az extrapolációt aug-cc-pV(Q,5,6)Z bázisokkal kapott eredményekkel végezték, a Martin és Lee által kidolgozott ${ }^{302,303}$ hárompontos formulával. Figyelembe vették továbbá a törzs-vegyérték korrelációs hozzájárulásokat, valamint az anharmonicitási és relativisztikus korrekciókat egyaránt. $142.6 \pm 0.8$ és $143.1 \pm 0.8 \mathrm{~kJ} \mathrm{~mol}^{-1}$-et közöltek a $\Delta_{f} H_{0}^{\circ}(\mathrm{SH})$ és $\Delta_{f} H_{298}^{\circ}(\mathrm{SH})$ mennyiségekre.

Császár és munkatársai ${ }^{298}$ az FPA-módszerrel ${ }^{43,44}$ számították a merkapto gyök képződési entalpiáját. A HF-SCF/CBS és az FC-CCSD(T)/CBS energiatagokat $(\mathrm{Q}, 5,6)$ valamint $(5,6)$ extrapolációval állították elő, az aug-cc-pV $(\mathrm{X}+d) \mathrm{Z}$ bázisokkal. A perturbatív háromszoros gerjesztési szint feletti hozzájárulások mértékét CCSDT és FCI számításokon keresztuil vették figyelembe. Ezeken túlmenően a DBOC és a nemrelativisztikus hatások is szerepeltek a teljes energia kifeje- 
zésben. A képződési entalpiára 0, valamint $298 \mathrm{~K}$-en a $141.2 \pm 0.5$ és $141.9 \pm 0.5 \mathrm{~kJ} \mathrm{~mol}^{-1}$-es eredményeket közölték.

Feller, Peterson és Dixon a korábban már említett 2008-as cikkében (ref. 77) szintén foglalkozik az SH gyök termokémiájával. A fenti FPA-módszerhez hasnoló protokolljuk $\Delta_{f} H_{298}^{\circ}(\mathrm{SH})$ $=141.0 \pm 0.8 \mathrm{~kJ} \mathrm{~mol}^{-1}$-et eredményezett.

Jelen munkában kidolgozott és alkalmazott HEAT-345 $+d(\mathrm{Q})$ modellel $\Delta_{f} H_{0}^{\circ}(\mathrm{SH})=142.8 \pm$ $\pm 1.9 \mathrm{~kJ} \mathrm{~mol}^{-1}$ és $\Delta_{f} H_{298}^{\circ}(\mathrm{SH})=143.4 \pm 1.9 \mathrm{~kJ} \mathrm{~mol}^{-1}$ entalpiaértékeket kaptunk. Adataink - hibahatáron belül - jól egyeznek a korábbi számítási ${ }^{77,298,299}$ és kísérleti ${ }^{297}$ eredményekkel. Mindazonáltal ezek az adatok kisebb-nagyobb eltéréseket mutatnak a Traeger-féle PIMS értékektől, ${ }^{293}$ ami alapján azt mondhatjuk, hogy a Traeger által számított $\pm 0.4 \mathrm{~kJ} \mathrm{~mol}^{-1}$-es hibahatár talán kissé optimisztikusnak tekinthető.

A merkapto gyök standard moláris entrópiájára az NIST-JANAF táblázat ${ }^{19} S_{298}^{\circ}(\mathrm{SH})=195.6 \pm$ $\pm 0.0 \mathrm{~J} \mathrm{~K}^{-1} \mathrm{~mol}^{-1}$-et listáz, ami Rosen ${ }^{304}$ kísérletileg meghatározott forgási és rezgési állandóiból származik. Janoschek és Rossi ${ }^{270}$ G3MP2B3 számításai a kicsivel magasabb 197.9 J K ${ }^{-1}$ mol $^{-1}$-es értéket adták. Jelen munkában $S_{298}^{\circ}(\mathrm{SH})=195.4 \pm 1.5 \mathrm{JK}^{-1} \mathrm{~mol}^{-1}$-et számítottunk, ami Janoschek és Rossi eredményével szemben megerôsíti a korai, 1970-es kísérleti értéket.

\section{$\mathrm{CH}_{2} \mathrm{SO}$}

A tiokarbonil-S-oxidok vagy másnéven szulfinok $\mathrm{R}_{1} \mathrm{R}_{2} \mathrm{C}=\mathrm{S}=\mathrm{O}$ általános képlettel leírható szubsztituált származékai régebb óta ismert, stabil vegyületek. Legegyszerúbb képviselőjük, a szubsztituálatlan $\mathrm{CH}_{2} \mathrm{SO}$ azonban instabil, laboratóriumban először 1976-ban állította elő Block és csoportja. ${ }^{305,306}$ Kísérleti módszerrel meghatározott standard képződési entalpiájára mindössze egyetlen érték, a Bouchoux és Salpin által közölt ${ }^{307} \Delta_{f} H_{298}^{\circ}\left(\mathrm{CH}_{2} \mathrm{SO}\right)=-8.0 \pm 10.0 \mathrm{~kJ} \mathrm{~mol}^{-1}$ létezik. Érdemes megjegyezni azonban, hogy ez az adat nem a képződéshő direkt méréséből származik, hanem a molekula gázfázisú bázicitásának és protonaffinitásának kísérleti értékéből számították.

Az 5.32. táblázatban látható, hogy Bouchoux és Salpin entalpiája jelentősen különbözik Benson egy korábbi becsült értékétől ${ }^{308}\left(-50.2 \pm 20.9 \mathrm{~kJ} \mathrm{~mol}^{-1}\right)$. Azonban remek egyezést mutat Ruttink és csoportja által CAS-SDCI/CASSCF szinten számított $-9.0 \pm 14.0 \mathrm{~kJ} \mathrm{~mol}^{-1}$-es eredményével. ${ }^{309}$ Számításaikhoz a Dunning-féle DZ(2df,2d,p)+f(S) bázist használták, mely tartalmaz két $d$ - és egy $f$-típusú függvényt a kénatomon, két $d$-típusút az $\mathrm{O}$ - és $\mathrm{C}$-atomokon, valamint egy p-típusút a H-en.

Néhány évvel később Ruttink és társai a CBS-QB3 kompozit modellel újraértékelték fenti eredményüket. ${ }^{310}$ Összesen 10 reakció bázisán, az előzőnél jóval mélyebb, de kisebb hibahatárral rendelkező $\Delta_{f} H_{298}^{\circ}\left(\mathrm{CH}_{2} \mathrm{SO}\right)=-30.0 \pm 6.0 \mathrm{~kJ} \mathrm{~mol}^{-1}$-es entalpiát kapták. A JPL adatbázis ${ }^{20}$ is ezt fogadja el referenciaként.

Ventura és munkatársai három egymást követô elméleti közleményben foglalkoztak a szulfin molekula képződési entalpiájával. Első közleményükben ${ }^{311}-52.0 \pm 10.0 \mathrm{~kJ} \mathrm{~mol}^{-1}$-nek számították a $\Delta_{f} H_{298}^{\circ}\left(\mathrm{CH}_{2} \mathrm{SO}\right)$ mennyiséget a B3LYP és B3PW91 sûrúségfunkcionálokkal, több Pople-féle 
bázis használatával a $\mathrm{CH}_{2} \mathrm{SO}+\mathrm{SO} \rightleftharpoons \mathrm{CH}_{2} \mathrm{~S}+\mathrm{SO}_{2}$ izodezmikus reakció bázisán. DFT eredményeik helyességét CCSD(T) számításokkal támasztották alá. A végleges értéket a B3PW91/6311++G(3df,2pd) és a CCSD(T)/6-311++G(2df,2pd) szinten meghatározott képződési entalpiák átlagaként állították elő. Második munkájukban ${ }^{312}$ a DFT és a CCSD(T) módszerek mellett MP2 számításokat is végeztek. Mindhárom szint esetében az előzőleg használt Pople-bázisokat Dunning korreláció-konzisztens készleteire cserélték. Új értéket nem közöltek, megerősítették az első cikkükben közölt $-52.0 \pm 10.0 \mathrm{~kJ} \mathrm{~mol}^{-1}$-es eredményüket.

Harmadik közleményükben ${ }^{313}$ a saját és a CBS-QB3 modellel számított ${ }^{310}$ értékek közötti ellentmondásosságot igyekeztek feloldani. Ennek érdekében három újabb, addig nem tanulmányozott reakciósémára végeztek DFT számításokat. Konklúziójuk szerint a több mint $20 \mathrm{~kJ} \mathrm{~mol}^{-1}$-es eltérést az eredetileg alkalmazott izodezmikus reakcióban szereplő triplett állapotú SO okozza. A $\mathrm{CH}_{2} \mathrm{SO}+\mathrm{SO}_{2} \rightleftharpoons \mathrm{CH}_{2} \mathrm{~S}+\mathrm{SO}_{3}$ valódi izodezmikus reakció bázisán, B3LYP/6-311++G(3df,2pd) elméleti szinten $\Delta_{f} H_{298}^{\circ}\left(\mathrm{CH}_{2} \mathrm{SO}\right)=-38.0 \pm 10.0 \mathrm{~kJ} \mathrm{~mol}^{-1}$-et kaptak.

\subsection{2. táblázat}

A $\mathrm{CH}_{2} \mathrm{SO}$ molekula irodalmi termodinamikai paraméterei. A képződési entalpiák $\mathrm{kJ} \mathrm{mol}^{-1}$, az entrópiák $\mathrm{J} \mathrm{K}^{-1} \mathrm{~mol}^{-1}$ egységben szerepelnek.

\begin{tabular}{|c|c|c|c|}
\hline$\Delta_{f} H_{0}^{\circ}$ & $\Delta_{f} H_{298}^{\circ}$ & $S_{298}^{\circ}$ & Módszer és referencia \\
\hline \multicolumn{4}{|l|}{ Kísérlet } \\
\hline & $-8.0 \pm 10.0$ & & 307 \\
\hline \multicolumn{4}{|l|}{ Számítás } \\
\hline & $-30.0 \pm 6.0$ & & CBS-QB3, 20, 310 \\
\hline & $-52.0 \pm 10.0$ & & $\operatorname{CCSD}(\mathrm{T}), 311$ \\
\hline & $-38.0 \pm 10.0$ & & DFT, 313 \\
\hline & $-33.1 \pm 10.3$ & & $\mathrm{cc}-\mathrm{CA}^{\mathrm{a}}, 84$ \\
\hline$-3.0 \pm 14.0$ & $-9.0 \pm 14.0$ & & CAS-SDCI, 309 \\
\hline-26.9 & & & $\mathrm{~W} 1$ 'b 314 \\
\hline \multicolumn{4}{|c|}{ Újraértékelés } \\
\hline & $-50.2 \pm 20.9$ & & 308 \\
\hline \multicolumn{4}{|c|}{ Jelen munka $[H E A T-345+\mathrm{d}(Q)]$} \\
\hline$-28.3 \pm 3.1$ & $-35.1 \pm 3.1$ & $261.4 \pm 1.5$ & \\
\hline
\end{tabular}

A HEAT-345+d(Q) protokoll 0 K-es eredménye, $-28.3 \pm 3.1 \mathrm{~kJ} \mathrm{~mol}^{-1}$, jól egyezik a W1'-ével, és ezen túlmenően jól definiált hibahatárral is rendelkezik. 298 K-es eredményünk $(-35.1 \pm 3.1$ $\mathrm{kJ} \mathrm{mol}^{-1}$ ) hibahatáron belül megegyezik a 310 és a 84 referenciákban közöltekkel, bár modellünk 
egyértelmúen felülmúlja mind a DFT, mind a korreláció-konzisztens kompozit módszerek ${ }^{80,81}$ (ccCA) pontosságát. Ez utóbbi megállapítás miatt azt mondhatjuk, hogy a jelen munkában számított $\Delta_{f} H_{0}^{\circ}\left(\mathrm{CH}_{2} \mathrm{SO}\right)$ és $\Delta_{f} H_{298}^{\circ}\left(\mathrm{CH}_{2} \mathrm{SO}\right)$ értékek az eddigi legpontosabbak és javasolt ezek új referenciaként történő felhasználása.

A $S_{298}^{\circ}\left(\mathrm{CH}_{2} \mathrm{SO}\right)$ tekintetében az itt számított $261.4 \pm 1.5 \mathrm{~J} \mathrm{~K}^{-1} \mathrm{~mol}^{-1}$ az elsô rendelkezésre álló adat.

\section{$\mathrm{CH}_{2} \mathrm{SH}$}

1992-ben három egymástól független közlemény jelent meg a $\mathrm{CH}_{2} \mathrm{SH}$ gyök termokémiai tulajdonságaival kapcsolatban. Ezek közül az egyik egy kísérleti tanulmány, míg a másik kettô elméleti számításos munka volt. (5.32. táblázat) Ruscic és Berkowitz ${ }^{317} \mathrm{a} \mathrm{CH}_{3} \mathrm{~S}$ és a $\mathrm{CH}_{2} \mathrm{SH}$ gyökök PIMS mérései alapján $\Delta_{f} H_{0}^{\circ}\left(\mathrm{CH}_{2} \mathrm{SH}\right)=157.7 \pm 8.4 \mathrm{~kJ} \mathrm{~mol}^{-1}$-es entalpiaértéket javasol. Továbbbá a $\mathrm{CH}_{2} \mathrm{SH}^{+}$ion korábban meghatározott küszöbpotenciálját kombinálva a $\mathrm{CH}_{2} \mathrm{SH}$ gyök IP-jával, egy felső korlátot is felállítottak a metil-merkaptán molekula, $\mathrm{CH}_{3} \mathrm{SH}, \mathrm{C}-\mathrm{H}$ kötésének erősségére. Ezt felhasználva, a $\mathrm{H}-\mathrm{CH}_{2} \mathrm{SH} \rightarrow \mathrm{H}+\mathrm{CH}_{2} \mathrm{SH}$ kötésdisszociációs reakció bázisán a képződési entalpiára a $\Delta_{f} H_{0}^{\circ}\left(\mathrm{CH}_{2} \mathrm{SH}\right) \leq 164.4 \pm 0.8 \mathrm{~kJ} \mathrm{~mol}^{-1}$-es felső korlátot adták meg. A JPL adatbázis ${ }^{20}$ $145.7 \pm 9.2 \mathrm{~kJ} \mathrm{~mol}^{-1}$-et listáz $298 \mathrm{~K}$-en. Forrásként Ruscic és Berkowitz PIMS munkáját adták meg, de a végső érték további, a gyưjteményben nem részletezett korrekció(k)ból állt elő.

Curtiss és társai, ${ }^{318}$ valamint Chiu és csoportja ${ }^{319}$ egymástól függetlenül vizsgálta különböző $\mathrm{CSH}_{n}$ összetételú gyökök és ionok termokémiai paramétereit a G2 módszerrel. A két csoport a hibahatár nélküli 169.9 és 170.7 kJ mol${ }^{-1}$-es értékeket közölte. Említésre méltó, hogy egyik eredmény sem felel meg a Ruscic és Berkowitz féle ${ }^{317} \Delta_{f} H_{0}^{\circ}\left(\mathrm{CH}_{2} \mathrm{SH}\right) \leq 164.4 \pm 0.8 \mathrm{~kJ} \mathrm{~mol}^{-1}$-es felső korlátnak. 
5.33. táblázat

A $\mathrm{CH}_{2} \mathrm{SH}$ gyök irodalmi termodinamikai paraméterei. A képződési entalpiák kJ mol ${ }^{-1}$, az entrópiák $\mathrm{J} \mathrm{K}^{-1} \mathrm{~mol}^{-1}$ egységben szerepelnek.

\begin{tabular}{|c|c|c|c|}
\hline$\Delta_{f} H_{0}^{\circ}$ & $\Delta_{f} H_{298}^{\circ}$ & $S_{298}^{\circ}$ & Módszer és referencia \\
\hline \multicolumn{4}{|l|}{ Kísérlet } \\
\hline $157.7 \pm 8.4$ & & & \multirow{2}{*}{317} \\
\hline$\leq 164.4 \pm 0.8$ & & & \\
\hline \multicolumn{4}{|l|}{ Számítás } \\
\hline 169.9 & & & $\mathrm{G} 2,318$ \\
\hline 170.7 & & & $\mathrm{G} 2,319$ \\
\hline \multicolumn{4}{|c|}{ Újraértékelés } \\
\hline & $145.7 \pm 9.2$ & & 20 \\
\hline \multicolumn{4}{|c|}{ Jelen munka $[H E A T-345+\mathrm{d}(Q)]$} \\
\hline $165.3 \pm 3.1$ & $160.2 \pm 3.1$ & $270.0 \pm 1.5$ & \\
\hline
\end{tabular}

Jelen munka eredményei, $\Delta_{f} H_{0}^{\circ}=165.3 \pm 3.1 \mathrm{~kJ} \mathrm{~mol}^{-1}$ és $\Delta_{f} H_{298}^{\circ}=160.2 \pm 3.1 \mathrm{~kJ} \mathrm{~mol}^{-1}$, jól egyeznek a korábban közöltekkel, továbbá a 0 K-es érték és hibahatáron belül teljesíti a felsô korlát feltételét is. Figyelembe véve az itt számított entalpia, valamint a limit értékét és a hozzájuk tartozó hibahatárokat elmondható, hogy a gyök képződési entalpiája a 162.2 és $165.2 \mathrm{~kJ} \mathrm{~mol}^{-1}$-es intervallumban van $\left(163.7 \pm 1.5 \mathrm{~kJ} \mathrm{~mol}^{-1}\right)$. Új referenciaként az itt számított pontos és jól definiált hibahatárral rendelkező eredményeket javasoljuk.

A jelen munka során számított $S_{298}^{\circ}\left(\mathrm{CH}_{2} \mathrm{SH}\right)=270.0 \pm 1.5 \mathrm{~J} \mathrm{~K}^{-1} \mathrm{~mol}^{-1}$-es érték a gyök standard moláris entrópiájának első rendelkezésre álló referenciaadata.

\section{$\mathrm{S}_{2} \mathrm{COH}$ és SCSOH}

Korábban már említettük, hogy a $\mathrm{CS}_{2}+\mathrm{OH}$ reakcióban képződő $\mathrm{CS}_{2} \mathrm{OH}$-nak az $\mathrm{OH}$-csoport kapcsolódási helyétôl függôen két konstitúciós izomere létezik: $\mathrm{S}_{2} \mathrm{COH}$ (C-izomer) és SCSOH (Sizomer) (5.1. ábra). A kérdéses reakció élénk érdeklődést váltott ki a légkörkémiával foglalkozó szakemberek körében, mivel sokáig nem sikerült azonosítani a reakcióban keletkező izomer szerkezetét. ${ }^{320}$ Petris és munkatársai voltak az elsők, akik direkt kísérletekben megfigyelték mindkét, szobahômérsékleten több mint $0.9 \mu$ s élettartammal képződő izomert. ${ }^{131}$

Hynes et al., ${ }^{321}$ Murrels et al. ${ }^{322}$ valamint Diau és Lee ${ }^{323}$ lézerindukált fluoreszcens spektroszkópiai módszerrel tanulmányozta a $\mathrm{CS}_{2}+\mathrm{OH}$ reakció kinetikai tulajdonságait egymástól függetlenül. Rendre $\Delta_{f} H_{298}^{\circ}\left(\mathrm{CS}_{2} \mathrm{OH}\right)=114.6 \pm 5.9,110.5 \pm 4.6$ és $112.0 \pm 5.0 \mathrm{~kJ} \mathrm{~mol}^{-1}$-et közöltek, valamint a 323 referenciában feltételezték az SCSOH izomer keletkezését. A JPL adatbázis ${ }^{20}$ a legkisebb hibahatárral rendelkező Murrels-féle értéket fogadta el referenciaként. 
5.34. táblázat

Az SCSOH gyök termodinamikai paraméterei. A képződési entalpiák $\mathrm{kJ} \mathrm{mol}^{-1}$, az entrópiák $\mathrm{J} \mathrm{K}^{-1} \mathrm{~mol}^{-1}$ egységben szerepelnek.

\begin{tabular}{cccc}
\hline \hline$\Delta_{f} H_{0}^{\circ}$ & $\Delta_{f} H_{298}^{\circ}$ & $S_{298}^{\circ}$ & Módszer és referencia \\
\hline \hline
\end{tabular}

Kísérlet

$$
\begin{array}{lrc}
110.5 \pm 4.6 & 321.0 \pm 20.0 & 20,322^{\mathrm{a}} \\
112.0 \pm 5.0 & \geq 318.8 & 323^{\mathrm{a}} \\
114.6 \pm 5.9 & & 321^{\mathrm{b}}
\end{array}
$$

Jelen munka [HEAT-345+d $(Q)]$

\begin{tabular}{rrrr}
$111.4 \pm 5.0$ & $108.9 \pm 5.0$ & $321.8 \pm 1.5$ & $\mathrm{SCSOH}$ \\
$20.1 \pm 4.6$ & $15.1 \pm 4.6$ & $296.9 \pm 1.5$ & $\mathrm{~S}_{2} \mathrm{COH}$ \\
\hline
\end{tabular}

a A kísérletekben az SCSOH izomer keletkezését feltételezték.

b Nem foglalkoztak a termék szerkezetének felderítésével.

$\mathrm{McKee}^{324}$ valamint McKee és Wine ${ }^{320}$ a $\mathrm{CS}_{2}+\mathrm{OH}$ reakció energetikai tulajdonságait vizsgálta elméleti módszerekkel. A G1 módszer kéntartalmú rendszerekre kidolgozott G1' (ref 324) variánsa mind az $\mathrm{SCSOH}$, mind az $\mathrm{S}_{2} \mathrm{COH}$ izomert stabiabbnak becsülte a két reaktánsnál. Mindazonáltal az S-izomer képződéséhez tartozó energiagát a C-izomeréhez képest $36.8 \mathrm{~kJ} \mathrm{~mol}^{-1}$-gyel kisebbnek bizonyult. A G1' eredmények alapján tehát Mckee azt a következtetést vonta le, ${ }^{324}$ hogy a kisebb energiagát miatt a reakcióban a termodinamikailag kedvezőtlenebb SCSOH izomer képződik. McKee és Wine ${ }^{320}$ a G2(MP2,SVP) módszerhez hasonló protokollal vizsgálta a $\mathrm{CS}_{2}$ atmoszférikus oxidációját. Tulajdonképpen QCISD(T)/6-311+G(3df,2p) relatív energiákat közelítettek QCISD(T)/6-31G(d) és MP2/6-311+G(3df,2p) szintû energiákkal B3LYP/6-31G(d) egyensúlyi geometriák és zéruspont rezgési energiák használatával. A számítások megerôsítették a korábbi eredményeket, miszerint mindkét izomer képződése energetikailag kedvező. Az OH kénatomhoz történő kapcsolódásának aktiválási energiáját szintén számították B3LYP és QCISD(T) szinten. Az elsố esetben a folyamat energiagát nélkülinek bizonyult, míg a második esetben csekély, 3.7 $\mathrm{kJ} \mathrm{mol}^{-1}$-es aktiválási energiát kaptak eredményül.

Az S-izomer HEAT-345+d(Q) protokollal kapott képződési entalpiája (5.34. táblázat) szintén megerősíti azt a feltételezést, miszerint ezen izomer (SCSOH) figyelhető meg kísérletileg az OH $+\mathrm{CS}_{2}$ reakcióban. Szintén ezt bizonyítja a folyamatra számított reakcióhő $\left(\Delta_{r} H^{\circ}\right)$, reakcióentrópia $\left(\Delta_{r} S^{\circ}\right)$, reakció-szabadentalpia $\left(\Delta_{r} G^{\circ}\right)$ valamint egyensúlyi állandó $(K)$. Az eredményeket az 5.35. táblázat tartalmazza, az egyes termodinamikai függvények számításának részletei pedig a 4.2 fejezetben olvashatók. Az $f$ bizonytalansági faktorral a $K$ egyensúlyi állandó alsó, illetve felsô határértékét tudjuk számítani úgy, hogy $K$ értékét osztjuk, illetve szorozzuk $f$ értékével. A 
faktort a hibaterjedés számítások szabályai szerint a

$$
f=\delta\left(\Delta_{r} G^{\circ}\right) /(R T)
$$

formula szerint számítjuk, ahol $\delta\left(\Delta_{r} G^{\circ}\right)$ a standard Gibbs reakcióenergia bizonytalansága.

\subsection{5. táblázat}

$\mathrm{CS}_{2}+\mathrm{OH}$ reakció termodinamikai paraméterei.

\begin{tabular}{lccccc}
\hline \hline Reakcióa $^{\mathrm{a}}$ & $\Delta_{r} H_{298}^{\circ}$ & $\Delta_{r} S_{298}^{\circ}{ }^{\mathrm{b}}$ & $\Delta_{r} G_{298}^{\circ}{ }^{\mathrm{b}}$ & $K$ & $f$ \\
\hline \hline $\mathrm{CS}_{2}+\mathrm{OH} \rightleftharpoons \mathrm{S}_{2} \mathrm{COH}$ & $-138.9 \pm 5.9$ & $-124.4 \pm 1.6$ & $-101.8 \pm 6.4$ & $2.80 \times 10^{-2}$ & 2.4 \\
$\mathrm{CS}_{2}+\mathrm{OH} \rightleftharpoons \mathrm{SCSOH}$ & $-45.1 \pm 6.3$ & $-99.8 \pm 1.6$ & $-15.3 \pm 6.8$ & $1.96 \times 10^{-17}$ & 2.7 \\
Kísérlet & $-45.6 \pm 4.2$ & $-100.4 \pm 18.4$ & $-15.7 \pm 9.7$ & $1.40 \times 10^{-17}$ & $1.4^{\mathrm{c}}$ \\
\hline \hline
\end{tabular}

a $\mathrm{A} \mathrm{CS}_{2}$ és OH képződési entalpia és entrópia értékei, valamint $K$ kísérleti értéke a 20 referenciából származnak. A kísérleti reakcióentalpia és -entrópia a 322 referenciából származik.

b Az értékek kJ mol ${ }^{-1}$ egységben szerepelnek.

c A JPL adatbázisból ${ }^{20}$ származó érték.

A fentieket összegezve tehát azt mondhatjuk, hogy figyelembe véve a HEAT-345+d(Q) modellel számított képződési entalpiákat, valamint összehasonlítva a $\mathrm{CS}_{2}+\mathrm{OH}$ reakcióra számított termodinamikai adatokat a kísérletiekkel, a kérdéses reakcióban minden bizonnyal az S-izomer, az SCSOH keletkezése figyelhető meg, annak ellenére, hogy termodinamikailag a másik izomerhez vezetô reakcióút a kedvezményezettebb.

Figyelembe véve a rendelkezésre álló adatok pontosságát, valamint a két konformer képződését övező bizonytalanságot, a jelen dolgozatban számított $\Delta_{f} H_{0}^{\circ}$ és $\Delta_{f} H_{298}^{\circ}$ eredményeket javasoljuk későbbi felhasználásra.

A standard moláris entrópiára Murrels és csoportja ${ }^{322} 321.0 \pm 20.0 \mathrm{~J} \mathrm{~K}^{-1} \mathrm{~mol}^{-1}$-es értéket származtatott kísérleti eredményeiből, míg Diau és $\mathrm{Lee}^{323}$ az $S_{298}^{\circ} \geq 318.8 \mathrm{~J} \mathrm{~K}^{-1} \mathrm{~mol}^{-1}$-es alsó korlátot állította fel. Protokollunk az S-izomerre, a fenti kísérleti eredményekkel kiválóan egyező $S_{298}^{\circ}=321.8 \pm 1.5 \mathrm{~J} \mathrm{~K}^{-1} \mathrm{~mol}^{-1}$-es entrópiaértéket eredményezte. A C-izomerre $S_{298}^{\circ}=296.9 \pm 1.5$ $\mathrm{J} \mathrm{K}^{-1} \mathrm{~mol}^{-1}$ adódott.

Érdemes megjegyezni, hogy jelen munka elsőként közöl pontos, jól definiált hibahatárral rendelkező adatokat a C-izomer, $\mathrm{S}_{2} \mathrm{COH}$, képződési entalpiájára és standard moláris entrópiájára. 


\subsubsection{Referenciaként történő felhasználásra javasolt adatok}

Az alábbi táblázatban foglaltam össze azokat a $\Delta_{f} H_{0}^{\circ}, \Delta_{f} H_{298}^{\circ}$ és $S_{298}^{\circ}$ adatokat, melyeket a fenti alfejezetek diszkussziói szerint az elérhető legpontosabbak, és amelyeket a későbbi termokémiai számításokban referenciaként történő felhasználásra javasolunk. Látható, hogy az SH gyök adatait és néhány entrópiaértéket leszámítva, szinte minden esetben a jelen munka során számított termokémiai paraméterek szerepelnek a táblázatban.

5.36. táblázat

A dolgozatban vizsgált szpécieszek referenciaként használható standard képződési entalpiái $\left(\mathrm{kJ} \mathrm{mol}^{-1}\right)$ és entrópiái $\left(\mathrm{J} \mathrm{K}^{-1} \mathrm{~mol}^{-1}\right)$. A dőlten szedett értékek a jelen munka eredményei.

\begin{tabular}{|c|c|c|c|c|}
\hline Szpéciesz & $\Delta_{f} H_{0}^{\circ}$ & $\Delta_{f} H_{298}^{\circ}$ & $S_{298}^{\circ}$ & forrás \\
\hline $\mathrm{H}_{2} \mathrm{CO}$ & $-105.42 \pm 0.40$ & $-109.23 \pm 0.40$ & & jelen munka \\
\hline $\mathrm{CF}_{2} \mathrm{O}$ & $-603.4 \pm 1.2$ & $-606.5 \pm 1.2$ & $258.9 \pm 0.1$ & $\begin{array}{l}\text { jelen munka } \\
S_{298}^{\circ} \text { : ref. } 19\end{array}$ \\
\hline FCO & $-177.2 \pm 0.9$ & $-176.7 \pm 0.9$ & $248.8 \pm 1.5$ & jelen munka \\
\hline $\mathrm{HFCO}$ & $-378.8 \pm 1.2$ & $-382.5 \pm 1.2$ & $246.5 \pm 0.8$ & $\begin{array}{l}\text { jelen munka } \\
S_{298}^{\circ} \text { : ref. } 19\end{array}$ \\
\hline $\mathrm{HClCO}$ & $-180.8 \pm 1.7$ & $-184.2 \pm 1.7$ & $259.1 \pm 0.2$ & $\begin{array}{l}\text { jelen munka } \\
S_{298}^{\circ}: \text { ref. } 218\end{array}$ \\
\hline $\mathrm{FClCO}$ & $-408.4 \pm 1.7$ & $-410.9 \pm 1.7$ & $276.7 \pm 0.2$ & $\begin{array}{l}\text { jelen munka } \\
S_{298}^{\circ}: \text { ref. } 218\end{array}$ \\
\hline cisz-HOCO & $-174.6 \pm 1.2$ & $-177.8 \pm 1.2$ & $251.7 \pm 1.5$ & jelen munka \\
\hline transz-HOCO & $-181.3 \pm 1.2$ & $-184.5 \pm 1.2$ & $251.4 \pm 1.5$ & jelen munka \\
\hline $\mathrm{NH}_{2} \mathrm{CO}$ & $-7.2 \pm 1.5$ & $-13.1 \pm 1.5$ & $256.5 \pm 1.5$ & jelen munka \\
\hline HSO & $-19.6 \pm 2.3$ & $-22.6 \pm 2.3$ & $241.4 \pm 1.5$ & jelen munka \\
\hline HOS & $-2.4 \pm 2.3$ & $-5.3 \pm 2.3$ & $240.0 \pm 1.5$ & jelen munka \\
\hline $\mathrm{HOSO}_{2}$ & $-367.5 \pm 4.4$ & $-375.7 \pm 4.4$ & $294.1 \pm 1.5$ & jelen munka \\
\hline transz-HSNO & $112.4 \pm 2.7$ & $107.3 \pm 2.7$ & $266.4 \pm 1.5$ & jelen munka \\
\hline cisz-HSNO & $115.8 \pm 2.7$ & $110.7 \pm 2.7$ & $266.1 \pm 1.5$ & jelen munka \\
\hline $\mathrm{SH}$ & $141.2 \pm 0.5$ & $141.9 \pm 0.5$ & $195.6 \pm 0.0$ & $\begin{array}{c}\Delta_{f} H_{T}^{\circ} \text { : ref. } 290 \\
S_{298}^{\circ}: \text { ref. } 19\end{array}$ \\
\hline $\mathrm{CH}_{2} \mathrm{SO}$ & $-28.3 \pm 3.1$ & $-35.1 \pm 3.1$ & $261.4 \pm 1.5$ & jelen munka \\
\hline $\mathrm{CH}_{2} \mathrm{SH}$ & $165.3 \pm 3.1$ & $160.2 \pm 3.1$ & $270.0 \pm 1.5$ & jelen munka \\
\hline $\mathrm{SCSOH}$ & $111.4 \pm 5.0$ & $108.9 \pm 5.0$ & $321.8 \pm 1.5$ & jelen munka \\
\hline $\mathrm{S}_{2} \mathrm{COH}$ & $20.1 \pm 4.6$ & $15.1 \pm 4.6$ & $296.9 \pm 1.5$ & jelen munka \\
\hline
\end{tabular}




\section{6. Összefoglalás}

Doktori munkámban kis méretú, maximum 4-5 nehézatomot tartalmazó, légkörkémiai szempontból fontos szabadgyökök és molekulák termokémiai paramétereinek tisztán elméleti úton történő számításával foglalkoztam. Dolgozatom elsődleges célja olyan ab initio elméleti kémiai modellek fejlesztése és alkalmazása volt, melyekkel a kérdéses szpécieszek standard képződési entalpiái, az ezekhez tartozó hőmérsékleti korrekciók, valamint a képződési entrópiák a kémiai pontosság alatti bizonytalansággal számíthatók. Az itt tanulmányozott gyökök és molekulák irodalomban hozzáférhetô korábbi referenciaadatai - mind a kísérleti, mind az elméleti úton meghatározottak - szinte minden esetben ellentmondásosak és/vagy komoly hibával terheltek, melyek miatt légköri modellekben és más termokémiai számításokban történő felhasználásuk bizonytalan eredményeket szolgáltathat.

A kérdéses paraméterek számításához három különböző, de felépítésükben hasonló kompozit ab initio termokémiai modellt definiáltam és alkalmaztam. A többé-kevésbé rendszerspecifikus modellekkel az egyes gyökök és molekulák teljes elektronenergiáját számíthatjuk más-más elméleti szinteken meghatározott, additívnek tekinthető hozzájárulások összege szerint, melyekből egyszerű termodinamikai összefüggések szerint származtatjuk a termokémiai mennyiségeket.

A vizsgálatok a formaldehid molekulával kezdődtek, melynek kicsiny mérete - összesen 16 elektron - magas elméleti szintek és nagy számú bázisfüggvények alkalmazását tette lehetôvé. Ezért felépítésében a „lentről-fel” (,,bottom-up”) elvet követő focal-point analízis módszere bizonyult a legkézenfekvőbb választásnak a képződési entalpia extrém nagy pontosságú $( \pm 0.3-0.4$ $\mathrm{kJ} \mathrm{mol}^{-1}$ ) számításához. Az alkalmazott protokoll a coupled-cluster kvantumkémiai módszeren alapult, melyen belül a rendszer nemrelativisztikus elektronenergiáját diffúz függvényekkel kiegészített korreláció-konzisztens bázisokkal és az erre alapuló extrapolációkkal számítottam. A jelen munkában definiált FPA modell a CC elméletből származó járulékokat egészen a perturbatív ötszörös gerjesztési szintig kezeli. A nemrelativisztikus elektronenergiát további korrekciókkal egészítettem ki: skaláris relativisztikus effektusok hatása, diagonális Born-Oppenheimer korrekció, zéruspont rezgési energia hozzájárulása. Az így előálló teljes molekuláris energiákból három reakció bázisán adtam meg a képződési entalpia $0 \mathrm{~K}$-en érvényes értékét. A három közül a $\mathrm{H}_{2}+$ $+\mathrm{CO}=\mathrm{H}_{2} \mathrm{CO}$ reakcióval kapható eredményt fogadtam el legpontosabbnak, melyet a két reaktáns nagy pontossággal rendelkezésre álló kísérleti $\Delta_{f} H_{0}^{\circ}$ értékének felhasználásával adtam meg. A $298.15 \mathrm{~K}$ hőmérsékleten érvényes $\Delta_{f} H_{298}^{\circ}$ adat a $0 \mathrm{~K}$-es eredményből származtatható a merev 
rotátor-harmonikus oszcillátor statisztikus termodinamikai modellel számított hômérsékleti korrekciók segítségével.

Az FPA modell végeredményei, $\Delta_{f} H_{0}^{\circ}\left(\mathrm{H}_{2} \mathrm{CO}\right)=-105.42 \pm 0.40 \mathrm{~kJ} \mathrm{~mol}^{-1}$ és $\Delta_{f} H_{298}^{\circ}\left(\mathrm{H}_{2} \mathrm{CO}\right)=$ $=-109.23 \pm 0.40 \mathrm{~kJ} \mathrm{~mol}^{-1}$, pontosságukat tekintve minden korábbi kísérleti és elméleti adatot felülmúlnak, ezért az itt közölt értékeket javasoltam referenciaként történő felhasználásra.

A formaldehid hidrogénjeinek eliminációjával és/vagy szubsztitúciójával levezethetô gyökök és molekulák irodalmi termokémiai paraméterei szinte kivétel nélkül megbízhatatlanok, így a kérdéses adatok revideálása nyilvánvalóan szükséges volt. A formaldehidnél definiált FPA protokoll alkalmazása ezekben az esetekben már nem volt lehetséges, a nehézatomok számának növekedésével ugyanis az egyes hozzájárulások számítása az FPA-ban bevezetett elméleti szinteken technikailag kivitelezhetetlennek bizonyult. Ezért ezekre a származékokra a HEAT-345(Q) elnevezésú ab initio termokémiai modellt alkalmaztam, melynek irodalomban közölt protokollját egyetlen pontjában, a DBOC számítási szintjében módosítottam. Nevezetesen a kérdéses korrekciót az eredeti formalizmus szerinti HF-SCF szint helyett CCSD módszerrel kezeltem.

A képződési entalpia számításának bázisa az elemekből történő képződési reakció volt, melyhez a HEAT-345(Q) által meghatározott teljes energiákat használtam. Az atomizációs reakciókhoz képest ez a kezelés elméletileg nem igényelne kísérletből származó paramétert, hiszen az elemi állapotok képződéshője definíció szerint zérus. Ezért várhatóan megbízhatóbb eredményeket kapunk, összehasonlítva az atomizációs bázisokon számított értékekkel, melyek származtatásához esetenként nem megfelelôen pontos atomi képződéshőket kell felhasználnunk. Azonban egyes esetekben az elemi állapotokra nem tudjuk elvégezni a protokollban előírt számításokat. Ilyenkor az alapállapotú atomot vesszük referenciaként, és ennek protokoll szerint meghatározott teljes energiáját, valamint irodalomból származó lehető legpontosabb képződéshőjét helyettesítjük a valódi elemi állapot helyére. Jelen munka során a szénatomra végeztem el az előírt számításokat, az atomi képződéshő, $\Delta_{f} H_{0}^{\circ}\left(\mathrm{C}_{\text {gáz }}\right)$, pedig egy korábbi nagy pontosságú ab initio tanulmányból származó érték volt. A $298.15 \mathrm{~K}$-re érvényes $\Delta_{f} H_{298}^{\circ}\left(\mathrm{C}_{\text {gáz }}\right)$ adat az NIST-JANAF adatbázisból származó hőmérsékleti korrekció felhasználásával állt elő.

A HEAT-345(Q) képződési entalpiákhoz és entrópiákhoz tartozó bizonytalanságot egy korábbi statisztikai analízis eredményeiből származtattam, melynek maximális értéke a klóratomot tartalmazó rendszereknél $\pm 1.7 \mathrm{~kJ} \mathrm{~mol}^{-1}$ volt. Minden egyes ezzel a modellel számított 0 és $298.15 \mathrm{~K}$-re vonatkozó képződési entalpia, valamint 4 esetben a 298.15 K-en érvényes entrópia pontosabbnak bizonyult minden korábban meghatározottnál.

A kénatom megjelenése az elméleti módszerekkel vizsgálandó rendszerekben több szempontból is problémákat okozhat. Az elektronok számának növekedésével a számítási szintek további kompromisszumos csökkentésére kényszerülünk a HEAT-345(Q) modellhez képest, ami nyilvánvalóan a végeredményekhez tartozó bizonytalanságot növeli. Felépítését tekintve az így definiálható modell - az FPA-val ellentétben - a „fentről-le” (,top-down”) filozófiát követi, hiszen mindaddig csökkentjük egy magas elméleti szintú modellben bevezetett módszereket és bázisokat, amíg 
azok alkalmazhatóvá nem válnak a kiterjedtebb rendszerekre is. Nyilvánvaló, hogy a redukált protokoll használhatóságát és teljesítőképességét tesztelnünk kell olyan kisebb és gyors eredményeket szolgáltató rendszerekre, melyeknek referenciaadatai nagy pontossággal elérhetőek. Amennyiben a modellel kapott és a referencia értékek közötti eltérések nagyobbak egy általunk kitúzött határértéknél, akkor a hiba felderítésének érdekében a protokoll egyes hozzájárulásait, illetve az összes felhasznált paramétert alaposan meg kell vizsgálnunk és további módosításokat kell eszközölnünk.

Doktori munkámban egy HEAT-345+d(Q) modellt definiáltam, mely az előző HEAT-345(Q)ból egyszerúsítésekkel vezethetô le. A legfontosabb különbség a két protokoll között a korrelációs energia törzs- és vegyértékelektronok szerinti szeparációjában rejlik. Míg a HEAT-345(Q) a korrelációs számításokban az összes elektront együttesen veszi figyelembe, addig a redukált modell különválasztva tárgyalja a törzs-törzs, törzs-vegyérték, valamint vegyérték-vegyérték korrelációs hatásokat.

A második lényeges különbség a számításokhoz használt bázisokat érinti. A kéntartalmú rendszerek HF-SCF és CC számításaihoz a(z) (aug-)cc-pVXZ bázisokat szoros $d$-típusú függvényekkel kellett kiegészíteni a hozzájárulások helyes konvergenciájának biztosításához. Erre a kiegészítésre utal a modell önkényes elnevezésében a ,,+d” jelölés.

Három gyök esetén a rendszer kiterjedt mérete miatt problémát okozott a magasabb rendú korrelációs hozzájárulások számítása is, nevezetesen a CCSDT(Q) járuléké. Ennek meghatározásához az MP2 FNO módszert alkalmaztam, mely redukálja a virtuális pályák számát a CC kezelés során, jelentôsen csökkentve a számítási igényt és időt.

Egyes molekulák esetén a kisfrekvenciás belsô mozgásokat az RRHO helyett a gátolt-rotátor modellel kellett kezelni, és a zéruspont rezgési energiákat, hőmérsékleti korrekciókat és az entrópiákat további korrekciók számításával pontosítani kellett. Ezekhez a számításokhoz a kérdéses molekulák konformációs analízisére volt szükség, melyből a korrekciók egy egydimenziós Schrödinger-egyenlet megoldásaiból álltak elő.

A szénhez hasonlóan a kén elemi állapota, $\mathrm{S}_{8}$, sem kezelhetô a HEAT-345+d(Q) modell szintjén, tehát itt is az atomi alapállapotot kellett referenciaként használni. Az atomhoz tartozó NISTJANAF táblázatból származó képződéshő pontatlansága további problémát okozott.

Az új modell ellenőrzéséhez egy 4 molekulából álló tesztkészletet választottam: $\mathrm{S}_{2}, \mathrm{H}_{2} \mathrm{~S}, \mathrm{SO}$ és $\mathrm{SO}_{2}$, melyekre összesen négy különböző szinteket használó protokollal végeztem összehasonító számolásokat. A kénatom, mint referencia képződéshőjét az NIST-JANAF táblázatból származtatva jelentős eltéréseket tapasztaltam még a legpontosabb protokoll alkalmazása mellett is. Egy közelmúltban megjelent, az $\mathrm{S}_{2}$ kísérleti disszociációs energiájának mérésével foglalkozó tanulmány eredményét kombinálva az NIST-JANAF atomi képződéshőjével és az ehhez tartozó hőmérsékleti korrekcióval, új $\Delta_{f} H_{0}^{\circ}\left(\mathrm{S}_{\mathrm{gáz}}\right)$ és $\Delta_{f} H_{298}^{\circ}\left(\mathrm{S}_{\text {gáz }}\right)$ értékeket vezettem be és javasoltam késôbbi használatra. Az ezekkel számított teszteredményeim a kísérleti referenciaadatokkal jól egyező képződési entalpiákat szolgáltattak. A négy tesztmodell eredményei alapján az alábbiakban összegzett megfigyeléseket tettem: 
i) A Dunning-féle (aug-)cc-pVXZ bázisok nagy exponensú (szoros) $d$-típusú függvényekkel történő kiegészítése a HF-SCF és CC számításokban mindenképpen szükséges a kéntartalmú származékok pontos kezeléséhez.

ii) Az előző kiegészítés nem vonatkozik egyrészt a geometriai optimalizálásokra, másrészt a zérusponti energiához szükséges frekvenciaszámításra.

iii) A törzselektronok korrelációját is kezelő (aug-)cc-pCVXZ készletek szintén nem szorulnak a fenti kiegészítésre.

iv) A HEAT-345+d(Q) modell (2. tesztmodell) a célul kitúzött pontosságon belül teljesít reálisnak tekinthető számítási időn belül.

A kéntartalmú származékokra bevezetett modellel összesen 10 molekulára végeztem számításokat, ebből 9 esetben a saját eredményeim bizonyultak a legpontosabbnak. Az $\mathrm{S}_{2} \mathrm{COH}$ esetén elsőként számítottam és közöltem képződési entalpia adatokat 0 és 298.15 K-en egyaránt, illetve további 6 esetben (HSO, HOS, cisz/transz-HSNO, $\mathrm{CH}_{2} \mathrm{SO}$ és $\mathrm{CH}_{2} \mathrm{SH}$ ) szintén elsôként becsültem a standard képződési entrópiákat. A HOS és HSO szerkezeti izomerek jelen munkában számított entalpiáit összehasonlítva a kísérleti eredményekkel azt következtettem, hogy a mérések során a feltételezett HSO helyett a HOS gyök képződését figyelték meg. Szintén ellentmondásos eredmények születtek az $\mathrm{S}_{2} \mathrm{COH}$ és $\mathrm{SCSOH}$ izomerek esetén. Ezért a $\mathrm{CS}_{2}+\mathrm{OH} \rightleftharpoons \mathrm{SCSOH} / \mathrm{S}_{2} \mathrm{COH}$ reakciók $\Delta_{r} H_{298}^{\circ}, \Delta_{r} S_{298}^{\circ}$ és $\Delta_{r} G_{298}^{\circ}$ értékeit, valamint egyensúlyi állandóját is meghatároztam a saját eredményeimet felhasználva. A termodinamikailag kevésbé stabil SCSOH képződése esetén a kísérletiekkel kiválóan egyező értékeket kaptam, így nagy valószínúséggel ez az izomer figyelhető meg a fenti reakcióban laboratóriumi és légköri körülmények között egyaránt, míg az $\mathrm{S}_{2} \mathrm{COH}-h o z$ vezető reakcióút kinetikailag gátolt.

Végső gondolatként érdemes megjegyezni, hogy a jelen dolgozat a benne közölt új referenciaadatok jelentőségén túlmenően, megerôsíti az elméleti kémia szerepét a termokémiai alkalmazásokban. A kísérleti módszerekhez képest a körültekintően kidolgozott $a b$ initio modellek - ahogyan azt a doktori munkám is bizonyítja - olyan kémiai rendszerekre is biztonsággal alkalmazhatók, melyek rövid élettartamuk, nagy reaktivitásuk, esetleg korlátozott hozzáférhetőségük miatt laboratóriumi körülmények között nehezen kezelhetők. 


\section{Summary}

My doctoral research focused on the high-accuracy theoretical calculation of thermochemical quantities for small (4-5 non-hydrogen atoms) radicals and molecules with relevance in atmospheric chemistry. The primary purpose was the development and application of ab initio model chemistries capable of calculating reliable standard enthalpies of formation, thermal corrections, and standard entropies for the above species with associated uncertainties lie below the chemical accuracy range. In almost all cases, the previously published thermochemical functions - both the experimentally and the theoretically derived ones - are inconsistent and/or they have too large error bars. Therefore, usage of these data in atmospheric modeling or other thermochemical calculations may provide uncertain and inadequate results.

In order to resolve the discrepancies among the thermodynamic properties in question and provide new and accurate estimates for these quantities, three different composite ab initio thermochemical models have been proposed and applied. With the aid of the more or less system specific protocols one can calculate the total electronic energies of chemical species as the sum of several contributions determined at various levels of theory. These contributions are treated additively and the final results can be obtained according to the simple rules of statistical thermodynamics.

The first study involved the heat of formation of the formaldehyde molecule. With its 16 electrons, $\mathrm{H}_{2} \mathrm{CO}$ is small enough to allow the application of very high levels of theory using large and extended basis sets. Therefore, the method of the so-called focal-point analysis, a „bottom-up” constructed model chemistry proved to be the best choice for the extremely accurate thermochemical calculations with an expected uncertainty not larger than approximately $\pm 0.3-0.4 \mathrm{~kJ} \mathrm{~mol}^{-1}$. With the coupled-cluster-based FPA protocol non-relativistic energies were calculated using the Dunning-type basis sets augmented with diffuse functions. From these results the complete basis set limit energies were also approximated via extrapolation techniques. The extrapolated nonrelativistic energy was further augmented with several important corrections, i.e., contributions from scalar relativistic effects, diagonal Born-Oppenheimer correction, and the zero-point vibrational energy. Based on the total molecular energies the final enthalpy of formation at $0 \mathrm{~K}$ was calculated using three reaction schemes. Among these schemes, the reaction $\mathrm{H}_{2}+\mathrm{CO}=\mathrm{H}_{2} \mathrm{CO}$ which involves only closed-shell species was expected to provide the most accurate result for $\Delta_{f} H_{0}^{\circ}\left(\mathrm{H}_{2} \mathrm{CO}\right)$. The necessary reference data for the two reactants with sufficiently low uncertainties were available in the literature. The enthalpy of formation at $298.15 \mathrm{~K}$ was estimated from 
the corresponding $0 \mathrm{~K}$ value using thermal corrections calculated via the standard formulas of statistical thermodynamics within the ideal gas approximation.

Considering their accuracy, the final FPA results, $\Delta_{f} H_{0}^{\circ}\left(\mathrm{H}_{2} \mathrm{CO}\right)=-105.42 \pm 0.40 \mathrm{~kJ} \mathrm{~mol}^{-1}$ and $\Delta_{f} H_{298}^{\circ}\left(\mathrm{H}_{2} \mathrm{CO}\right)=-109.23 \pm 0.40 \mathrm{~kJ} \mathrm{~mol}^{-1}$, surpassed all previous experimental and theoretical data, and, therefore, I recommended these results as new reference values.

Several derivatives can be obtained from the formaldehyde molecule by elimination and/or substitution of its hydrogen atoms. The thermochemical parameters of these radicals and molecules are also uncertain or inaccurate, so the revision of them by means of a high-level $a b$ initio model chemistry was clearly necessary. Applying the FPA approach to these chemical systems was unfortunately prohibited because the increasing number of electrons made the calculations of the various contributions to be technically unaffordable at those high levels of theory which were defined in the FPA method. Therefore, a slightly modified version of the HEAT-345(Q) ab initio model chemistry has been applied to the formaldehyde derivatives. The slight modification dealt with the the DBOC correction which was calculated with the correlated CCSD method rather than at the uncorrelated HF-SCF level as it was defined in the original protocol.

To obtain the final heat of formation values from the calculated total energies, the elemental reaction approach was used. Ideally, in this manner, no experimental parameters are needed, since the heats of formation of the elements are zero by definition. The accuracy of the final results calculated by this approach is expected to be better as compared with that of the values can be obtained via the atomization reaction scheme because the required atomic quantities are not always perfectly reliable. However, there are several elemental states for which the calculations prescribed in the protocol are impossible. In these cases the gas phase ground state atom is used as reference, and its atomic heat of formation along with its total energy are substituted for the parameters of the elemental state. In this work, such substitution was made in the case of the carbon atom, i.e., the HEAT-345(Q) method was applied to the atom, and its highly accurate heat of formation value, $\Delta_{f} H_{0}^{\circ}\left(\mathrm{C}_{\mathrm{gas}}\right)$, was taken from a previous ab initio study. $\Delta_{f} H_{298}^{\circ}\left(\mathrm{C}_{\mathrm{gas}}\right)$ was obtained by adding the thermal correction of the NIST-JANAF tables to the $0 \mathrm{~K}$ data.

Error bars introduced by the HEAT-345(Q) protocol were taken from a previous statistical analysis. The largest uncertainty of $\pm 1.7 \mathrm{~kJ} \mathrm{~mol}^{-1}$ was associated with the chlorine containing species. To sum up, we can conclude that the HEAT-345(Q) model chemistry performed well, and all enthalpies of formation at both 0 and $298.15 \mathrm{~K}$ along with four entropy data calculated here were proved to be the most accurate results to date.

Introducing the sulfur atom into the chemical species may cause several computational issues. Because of the size of these systems, we have no other choice but to further reduce the levels of theory applied in the protocol in order to make the calculations performable. Obviously, as opposed to the FPA approach, this kind of model chemistry which can be obtained via the reduction of levels is a „top-down,, constructed protocol where, clearly, the accuracy of the resulting thermochemical quantities is reduced as well. Applicability and efficiency of a newly developed protocol 
should always be tested against smaller chemical systems for which reliable reference values are available to sufficiently high accuracy. If the difference between the results of the new model and the reference data exceeds an arbitrarily defined threshold then the various contributions taken into consideration in the protocol along with all external parameters, e.g., experimental heats of formation for atomic species, should be investigated thoroughly and further modifications should be introduced into our model.

In my doctoral study a HEAT- $345+d(\mathrm{Q})$ model chemistry has been proposed which can be derived from its higher-level HEAT-345(Q) predecessor by several simplifications. The most important such reduction is the separation of the core and valence correlation effects. While the HEAT-345(Q) model takes into account all electrons in the correlation calculations, the reduced protocol treats the core-core, core-valence, and valence-only correlation effects separately.

The second crucial difference lies in the basis sets applied in the calculations. In order to obtain sufficiently converged HF-SCF and CC contributions for the sulfur containing species, the traditional (aug-)cc-pVXZ sets were further augmented with high-exponent tight- $d$ functions. The notation " $+d$, in the name of the protocol refers to this completion.

Because of the steep scaling of the $\operatorname{CCSDT}(\mathrm{Q})$ method with the number of virtual orbitals, the computation of the higher-order correlation term for three open-shell species studied here was impossible to carry out. In these cases the MP2 FNO approach has been invoked which reduces the number of virtual orbitals by defining a threshold for their occupation. In this manner the computational demand and time can be significantly reduced, although, uncertainties of the final results slightly increase.

A further issue was the proper treatment of the low-frequency motions in the case of six molecules where the conventional RRHO model was not straightforwardly applicable. The zero-point vibrational energies, temperature corrections, and entropies were corrected here by using a onedimensional hindered-rotor model. To this end conformational analysis for the six species in question was performed and a one-dimensional Schrödinger equation was solved.

Finally, applying the HEAT-345 $+d(\mathrm{Q})$ model to the reference elemental state of sulfur, $\mathrm{S}_{8}$, was also prohibited. Therefore, similarly to carbon, the gas phase sulfur atom was taken as reference in the derivation of the final thermochemical quantities. The inaccuracy of the atomic heat of formation taken from the NIST-JANAF database implied further issues as discussed below.

The accuracy of the reduced protocol were proven by performing calculations on a test set containing four molecules: $\mathrm{S}_{2}, \mathrm{H}_{2} \mathrm{~S}, \mathrm{SO}$, and $\mathrm{SO}_{2}$. During the development of the final HEAT$345+d(\mathrm{Q})$ model three other protocols were also investigated and applied to the above four species. Using the NIST-JANAF heat of formation value for the reference sulfur atom, significant differences were observed between the calculated results and the high-quality literature data of the test set even with the most accurate protocol. Based on a recently published experimental study on the dissociation energy of the $\mathrm{S}_{2}$ molecule, new reference values for $\Delta_{f} H_{0}^{\circ}\left(\mathrm{S}_{\mathrm{gas}}\right)$ and $\Delta_{f} H_{298}^{\circ}\left(\mathrm{S}_{\mathrm{gas}}\right)$ have been deduced by combining the NIST-JANAF heat of formation and its thermal correction with 
the measured $D_{0}\left(\mathrm{~S}_{2}\right)$ parameter. With these new references my test results showed a very good agreement with the literature values. Considering the outcome of the four different models, the following conclusions can be drawn:

i) For sulfur containing species the Dunning-type (aug-)cc-pVXZ basis sets used in the HFSCF and CC calculations have to be further augmented with high-exponent tight- $d$ functions.

ii) The above augmentation does not hold either for geometry optimizations or for frequency calculations.

iii) Augmentation of the (aug-)cc-pCVXZ core-correlation basis sets is also not necessary because they a priori contain the sufficient number of $d$-type functions.

iv) The final HEAT-345 $+d(\mathrm{Q})$ model (second test model) provides results within the target accuracy range in a reasonable computational time.

A total of ten sulfur containing species has been investigated by means of the HEAT- $345+d(\mathrm{Q})$ $a b$ initio model chemistry and for nine of them this doctoral work delivers the most accurate thermochemical quantities. Furthermore, my study is the first one which reports data with a wellestablished error bar for the heats of formation of the $\mathrm{S}_{2} \mathrm{COH}$ radical both at 0 and $298.15 \mathrm{~K}$ and in additional six cases (HSO, $\mathrm{SOH}$, cis/trans-HSNO, $\mathrm{CH}_{2} \mathrm{SO}$, and $\mathrm{CH}_{2} \mathrm{SH}$ ) the calculated entropies are the first available estimates as well. Comparing the enthalpies of formation obtained in this work with the previously published experimental results for the structural isomers HSO and HOS, it was concluded that instead of the assumed HSO, HOS was most likely observed in the measurements. Experimental findings for the isomer pair $\mathrm{S}_{2} \mathrm{COH}$ and $\mathrm{SCSOH}$ are also contradictory. To resolve this issue, the thermochemical parameters of the reactions $\mathrm{CS}_{2}+\mathrm{OH} \rightleftharpoons \mathrm{SCSOH} / \mathrm{S}_{2} \mathrm{COH}$ were also computed using the results of this work for the product radicals. Particularly, the quantities $\Delta_{r} H_{298}^{\circ}, \Delta_{r} S_{298}^{\circ}$, and $\Delta_{r} G_{298}^{\circ}$ along with the equilibrium constants were determined. In that case when the formation of the thermodynamically less stable S-adduct, $\mathrm{SCSOH}$, was proposed in the above reaction, the resulting thermodynamic properties agreed well with those obtained in the experiments. On the basis of this finding it was concluded that the reaction channel yielding this isomer was the kinetically favored one in the laboratory as well as in the atmosphere.

As a final conclusion it is worth noting that beyond the new and highly accurate reference values for the various thermodynamic quantities, my doctoral study also confirms the significant role of the ab initio quantum chemical methods in thermochemical applications. Compared with the experimental techniques, reasonably built theoretical model chemistries are almost always applicable with absolute certainty even in difficult cases when the studied species have very short lifetimes, high reactivities or limited availabilities. 


\section{Köszönetnyilvánítás}

Köszönettel tartozom Dr Kiricsi Imrének† és Dr Kónya Zoltánnak, az Alkalmazott és Környezeti Kémia Tanszék korábbi és jelenlegi vezetőjének, amiért lehetővé tették számomra, hogy doktori munkámat a tanszékükön végezzem.

Köszönet illeti témavezetômet, Dr Tasi Gyulát, a magas színvonalú szakmai irányításért, valamint a doktori tanulmányaim során nyújtott minden támogatásáért.

Köszönöm a BME Fizikai Kémiai és Anyagtudományi Tanszékén múködő Spektroszkópia Csoport vezetőjének, Dr Kállay Mihálynak, hogy technikai lehetôséget biztosított a számításaim kivitelezéséhez. Hálával tartozom a csoport többi tagjának, kollégáimnak, Dr Rolik Zoltánnak és Dr Csontos Józsefnek a munkám során felmerült problémák megoldásában, illetve a dolgozatom alapjául szolgáló kéziratok elkészítésében nyújtott segítségükért.

Szintén köszönet illeti Dr Császár Attilát és Dr Czakó Gábort az ELTE Molekulaspektroszkópia Csoportból a formaldehid molekula számításaihoz és az ezzel foglalkozó kézirat elkészítéséhez nyújtott segítségükért.

Hálás vagyok az Alkalmazott és Környezeti Kémia Tanszék minden dolgozójának a nagyszerú munkahelyi légkörért.

Köszönet illeti középiskolai kémiatanáromat, Meleg Istvánt†, aki felejthetetlen kémiaóráival érdeklődésemet a természettudományok felé fordította.

Köszönöm az Új-Széchenyi Terv, TÁMOP-4.2.2/B-10/1-2010-0009 projekt által nyújtott financiális támogatást.

Hálával tartozom Szüleimnek, akik önfeláldozó munkájukkal és szeretetükkel támogattak egyetemi és doktori tanulmányaim alatt egyaránt. 


\section{Irodalomjegyzék}

[1] P. Maksyutenko, T. R. Rizzo, and O. V. Boyarkin, J. Chem. Phys. 2006, 125, 181101.

[2] J. Liu, E. J. Salumbides, U. Hollenstein, J. C. J. Koelemeij, K. S. E. Eikema, W. Ubachs, and F. Merkt, J. Chem. Phys. 2009, 130, 174306.

[3] B. Ruscic, A. F. Wagner, L. B. Harding, R. L. Asher, D. Feller, D. A. Dixon, K. A. Peterson, Y. Song, X. Qian, C.-Y. Ng, J. Liu, W. Chen, and D. W. Schwenke, J. Phys. Chem. A 2002, 106, 2727.

[4] R. M. Balabin, J. Phys. Chem. A 2009, 113, 1012.

[5] G. Tasi, F. Mizukami, I. Pálinkó, J. Csontos, W. Győrffy, P. Nair, K. Maeda, M. Toba, S.-i. Niwa, Y. Kiyozumi, and I. Kiricsi, J. Phys. Chem. A 1998, 102, 7698.

[6] G. Tasi and F. Mizukami, J. Math. Chem. 1999, 25, 55.

[7] G. Tasi, F. Mizukami, J. Csontos, W. Győrffy, and I. Pálinkó, J. Math. Chem. 2000, 27, 191.

[8] G. Tasi, B. Nagy, G. Matisz, and T. S. Tasi, Comput. Theor. Chem. 2011, 963, 378 .

[9] J. M. L. Martin, J. Phys. Chem. A 2013, 117, 3118.

[10] K. Piszczatowski, G. Łach, M. Przybytek, J. Komasa, K. Pachucki, and B. Jeziorski, J. Chem. Theor. Comp. 2009, 5, 3039.

[11] K. Pachucki and J. Komasa, Phys. Chem. Chem. Phys. 2010, 12, 9188.

[12] B. Ruscic, R. E. Pinzon, M. L. Morton, G. von Laszewski, S. J. Bittner, S. G. Nijsure, K. A. Amin, M. Minkoff, and A. F. Wagner, J. Phys. Chem. A 2004, 108, 9979.

[13] A. Császár and T. Furtenbacher, Chem. Eur. J. 2010, 16, 4826.

[14] B. Ruscic, J. E. Boggs, A. Burcat, A. G. Csaszar, J. Demaison, R. Janoschek, J. M. L. Martin, M. L. Morton, M. J. Rossi, J. F. Stanton, P. G. Szalay, P. R. Westmoreland, F. Zabel, and T. Berces, J. Phys. Chem. Ref. Data 2005, 34, 573.

[15] M. E. Harding, J. Vázquez, J. Gauss, J. F. Stanton, and M. Kállay, J. Chem. Phys. 2011, 135, 044513. 
[16] G. Tasi and B. Nagy, J. Phys. Chem. A 2010, 114, 6728.

[17] D. Barna, B. Nagy, J. Csontos, A. Császár, and G. Tasi, J. Chem. Theor. Comp. 2012, 8, 479.

[18] J. Csontos, B. Nagy, M. Kállay, and G. Tasi, kézirat készülőben, J. Phys. Chem. A, 2013.

[19] M. W. Chase, Jr., NIST-JANAF Thermochemical Tables, 4th ed., J. Phys. Chem. Ref. Data, Monograph Vol. 9, 1998.

[20] S. P. Sander, R. R. Friedl, D. M. Golden, M. J. Kurylo, G. K. Moortgat, P. H. Wine, A. R. Ravishankara, C. E. Kolb, M. J. Molina, B. J. Finlayson-Pitts, R. E. Huie, and V. L. Orkin, Chemical Kinetics and Photochemical Data for Use in Atmospheric Studies, Evaluation Number 15, NASA Jet Propulsion Laboratory Publication, California Institute of Technology, Pasadena, CA, 2006.

[21] J. D. Cox, D. D. Wagman, and V. A. Medvedev, Hemisphere, New York, NY, 1989, see also http://www.codata.org/resources/databases/key1.html.

[22] A. Burcat and B. Ruscic, Third Millennium Ideal Gas and Condensed Phase Thermochemical Database for Combustion with updates from Active Thermochemical Tables, ANL-05/20 and TAE 960, Technion-IIT, Aerospace Engineering, and Argonne National Laboratory, Chemistry Division, September 2005. ftp://ftp.technion.ac.il/pub/supported/aetdd/thermodynamics mirrored at http://garfield.chem.elte.hu/Burcat/burcat.html (accessed in March 2010).

[23] P. Linstrom and W. Mallard, Eds., NIST Chemistry WebBook, NIST Standard Reference Database Number 69, National Institute of Standards and Technology, Gaithersburg MD, 20899, http://webbook.nist.gov, (retrieved February 5, 2013).

[24] NIST Computational Chemistry Comparison and Benchmark Database, NIST Standard Reference Database Number 101, Release 15b, August 2011, Editor: Russell D. Johnson III, http://cccbdb.nist.gov/, (retrieved February 5, 2013).

[25] G. Petersson, A. Bennett, T. Tensfeldt, M. Al-Laham, W. Shirley, and J. Mantzaris, J. Chem. Phys. 1988, 89, 2193.

[26] G. Petersson and M. Al-Laham, J. Chem. Phys. 1991, 94, 6081.

[27] G. Petersson, T. Tensfeldt, and J. Montgomery Jr, J. Chem. Phys. 1991, 94, 6091.

[28] J. J. A. Montgomery, J. W. Ochterski, and G. A. Petersson, J. Chem. Phys. 1994, 101, 5900.

[29] J. W. Ochterski, G. A. Petersson, and J. J. A. Montgomery, J. Chem. Phys. 1996, 104, 2598. 
[30] J. A. Pople, M. Head-Gordon, D. J. Fox, K. Raghavachari, and L. A. Curtiss, J. Chem. Phys. 1989, 90, 5622.

[31] L. A. Curtiss, K. Raghavachari, G. W. Trucks, and J. A. Pople, J. Chem. Phys. 1991, 94, 7221.

[32] L. Curtiss, K. Raghavachari, P. Redfern, V. Rassolov, and J. Pople, J. Chem. Phys. 1998, 109, 7764.

[33] L. A. Curtiss, P. C. Redfern, and K. Raghavachari, J. Chem. Phys. 2007, 126, 084108.

[34] R. M. Balabin, J. Phys. Chem. A 2010, 114, 6729.

[35] S. E. Wheeler, K. N. Houk, P. V. R. Schleyer, and W. D. Allen, J. Am. Chem. Soc. 2009, $131,2547$.

[36] G. Tasi, R. Izsák, G. Matisz, A. G. Császár, M. Kállay, B. Ruscic, and J. F. Stanton, ChemPhysChem 2006, 7, 1664.

[37] B. Nagy, Diplomamunka, Szegedi Tudományegyetem, Szeged, 2008.

[38] Gaussian 09, Revision A.01, M. J. Frisch, G. W. Trucks, H. B. Schlegel, G. E. Scuseria, M. A. Robb, J. R. Cheeseman, G. Scalmani, V. Barone, B. Mennucci, G. A. Petersson, H. Nakatsuji, M. Caricato, X. Li, H. P. Hratchian, A. F. Izmaylov, J. Bloino, G. Zheng, J. L. Sonnenberg, M. Hada, M. Ehara, K. Toyota, R. Fukuda, J. Hasegawa, M. Ishida, T. Nakajima, Y. Honda, O. Kitao, H. Nakai, T. Vreven, J. A. Montgomery, Jr., J. E. Peralta, F. Ogliaro, M. Bearpark, J. J. Heyd, E. Brothers, K. N. Kudin, V. N. Staroverov, R. Kobayashi, J. Normand, K. Raghavachari, A. Rendell, J. C. Burant, S. S. Iyengar, J. Tomasi, M. Cossi, N. Rega, J. M. Millam, M. Klene, J. E. Knox, J. B. Cross, V. Bakken, C. Adamo, J. Jaramillo, R. Gomperts, R. E. Stratmann, O. Yazyev, A. J. Austin, R. Cammi, C. Pomelli, J. W. Ochterski, R. L. Martin, K. Morokuma, V. G. Zakrzewski, G. A. Voth, P. Salvador, J. J. Dannenberg, S. Dapprich, A. D. Daniels, Ö.. Farkas, J. B. Foresman, J. V. Ortiz, J. Cioslowski, and D. J. Fox, Gaussian Inc. Wallingford CT 2009.

[39] L. A. Curtiss, P. C. Redfern, and K. Raghavachari, J. Chem. Phys. 2005, 123, 124107.

[40] J. P. Perdew, A. Ruzsinszky, L. A. Constantin, J. Sun, and G. I. Csonka, J. Chem. Theor. Comp. 2009, 5, 902.

[41] D. Bakowies, J. Phys. Chem. A 2013, 117, 228.

[42] G. da Silva, Chem. Phys. Lett. 2013, 558, 109. 
[43] W. D. Allen, A. L. L. East, and A. G. Császár, in Structures and Conformations of NonRigid Molecules, J. Laane, M. Dakkouri, B. van der Veken, and H. Oberhammer, Eds., p. 343, Kluwer, Dodrecht, 1993.

[44] A. G. Császár, W. D. Allen, and H. F. Schaefer III, J. Chem. Phys. 1998, 108, 9751.

[45] A. L. L. East and W. D. Allen, J. Chem. Phys. 1993, 99, 4638.

[46] G. Czakó, E. Mátyus, A. C. Simmonett, A. G. Császár, H. F. Schaefer III, and W. D. Allen, J. Chem. Theor. Comp. 2008, 4, 1220.

[47] J. Csontos and M. Kállay, J. Phys. Chem. A 2011, 115, 7765.

[48] J. M. L. Martin and G. de Oliveira, J. Chem. Phys. 1999, 111, 1843.

[49] A. D. Boese, M. Oren, O. Atasoylu, J. M. L. Martin, M. Kállay, and J. Gauss, J. Chem. Phys. 2004, 120, 4129.

[50] A. Karton, E. Rabinovich, J. M. L. Martin, and B. Ruscic, J. Chem. Phys. 2006, 125, 144108.

[51] A. Tajti, P. G. Szalay, A. G. Császár, M. Kállay, J. Gauss, E. F. Valeev, B. A. Flowers, J. Vázquez, and J. F. Stanton, J. Chem. Phys. 2004, 121, 11599.

[52] Y. J. Bomble, J. Vazquéz, M. Kállay, C. Michauk, P. G. Szalay, A. G. Császár, J. Gauss, and J. F. Stanton, J. Chem. Phys. 2006, 125, 064108.

[53] M. E. Harding, J. Vázquez, B. Ruscic, A. K. Wilson, J. Gauss, and J. F. Stanton, J. Chem. Phys. 2008, 128, 114111.

[54] J. Martin and S. Parthiban, in Quantum-Mechanical Prediction of Thermochemical Data, Understanding Chemical Reactivity, vol. 22, J. Cioslowski, Ed., pp. 31-65, Springer Netherlands, 2002.

[55] A. Karton, P. R. Taylor, and J. M. L. Martin, J. Chem. Phys. 2007, 127, 064104.

[56] B. Csontos, B. Nagy, J. Csontos, and M. Kállay, J. Phys. Chem. A 2013, 117, 5518.

[57] L. Kong, F. A. Bischoff, and E. F. Valeev, Chem. Rev. 2012, 112, 75.

[58] S. Ten-no and J. Noga, WIREs Comput. Mol. Sci. 2012, 2, 114.

[59] Az aktuális verziót lásd a http://www.mrcc.hu/ honlapon .

[60] M. Kállay and P. R. Surján, J. Chem. Phys. 2001, 115, 2945.

[61] M. Kállay and J. Gauss, J. Chem. Phys. 2004, 120, 6841. 
[62] M. Kállay and P. R. Surján, J. Chem. Phys. 2000, 113, 1359.

[63] B. A. Flowers, P. G. Szalay, J. Vazquéz, J. F. Stanton, M. Kállay, J. Gauss, and A. G. Császár, J. Phys. Chem. A 2004, 108, 3195.

[64] D. Feller, J. Chem. Phys. 1999, 111, 4373.

[65] D. Feller and J. A. Sordo, J. Chem. Phys. 2000, 113, 485.

[66] T. A. Ruden, T. Helgaker, P. Jørgensen, and J. Olsen, Chem. Phys. Lett. 2003, 371, 62.

[67] D. Bakowies, J. Chem. Phys. 2009, 130, 144113.

[68] S. Kondo, A. Takahashi, and K. Tokuhashi, J. Hazard. Mater. 2002, 94, 37 .

[69] C. F. Melius and J. S. Binkley, Symp. (Int.) Combust. 1988, 21, 1953 .

[70] D. Dixon and D. Feller, J. Phys. Chem. A 1998, 102, 8209.

[71] D. Feller, D. A. Dixon, and J. S. Francisco, J. Phys. Chem. A 2003, 107, 1604.

[72] D. Feller, K. A. Peterson, W. A. de Jong, and D. A. Dixon, J. Chem. Phys. 2003, 118, 3510.

[73] D. Feller and N. C. Craig, J. Phys. Chem. A 2009, 113, 1601.

[74] D. Feller, K. A. Peterson, and D. A. Dixon, J. Phys. Chem. A 2011, 115, 1440.

[75] D. Feller and J. M. Simmie, J. Phys. Chem. A 2012, 116, 11768.

[76] D. Feller, K. A. Peterson, and T. D. Crawford, J. Chem. Phys. 2006, 124, 054107.

[77] D. Feller, K. Peterson, and D. Dixon, J. Chem. Phys. 2008, 129, 204105.

[78] D. Feller, K. A. Peterson, and J. G. Hill, J. Chem. Phys. 2011, 135, 044102.

[79] D. Feller, K. A. Peterson, and D. A. Dixon, Mol. Phys. 2012, 110, 2381.

[80] N. J. DeYonker, T. R. Cundari, and A. K. Wilson, J. Chem. Phys. 2006, 124, 114104.

[81] N. J. DeYonker, T. Grimes, S. Yockel, A. Dinescu, B. Mintz, T. R. Cundari, and A. K. Wilson, J. Chem. Phys. 2006, 125, 104111.

[82] D. S. Ho, N. J. DeYonker, A. K. Wilson, and T. R. Cundari, J. Phys. Chem. A 2006, 110, 9767.

[83] T. V. Grimes, A. K. Wilson, N. J. DeYonker, and T. R. Cundari, J. Chem. Phys. 2007, 127, 154117.

[84] T. G. Williams and A. K. Wilson, J. Sulfur Chem. 2008, 29, 353. 
[85] N. J. DeYonker, B. Mintz, T. R. Cundari, and A. K. Wilson, J. Chem. Theor. Comp. 2008, 4, 328.

[86] M. L. Laury, N. J. DeYonker, W. Jiang, and A. K. Wilson, J. Chem. Phys. 2011, 135, 214103.

[87] K. R. Jorgensen, G. A. Oyedepo, and A. K. Wilson, J. Hazard. Mater. 2011, 186, 583.

[88] S. Dapprich, I. Komáromi, K. Byun, K. Morokuma, and M. J. Frisch, J. Mol. Struct. (THEOCHEM) 1999, 461-462, 1 .

[89] T. Vreven and K. Morokuma, in Annual Reports in Computational Chemistry, vol. 2, D. C. Spellmeyer, Ed., pp. 35 - 51, Elsevier, 2006.

[90] S. R. Das, T. G. Williams, M. L. Drummond, and A. K. Wilson, J. Phys. Chem. A 2010, 114, 9394.

[91] G. A. Oyedepo and A. K. Wilson, J. Phys. Chem. A 2010, 114, 8806.

[92] G. A. Oyedepo, C. Peterson, and A. K. Wilson, J. Chem. Phys. 2011, 135, 094103.

[93] P. L. Fast, J. C. Corchado, M. L. Sánchez, and D. G. Truhlar, J. Phys. Chem. A 1999, 103, 5129.

[94] F. B. Brown and D. G. Truhlar, Chemical Physics Letters 1985, 117, 307 .

[95] M. S. Gordon and D. G. Truhlar, J. Am. Chem. Soc. 1986, 108, 5412.

[96] P. L. Fast and D. G. Truhlar, J. Phys. Chem. A 2000, 104, 6111.

[97] B. J. Lynch and D. G. Truhlar, J. Phys. Chem. A 2003, 107, 3898.

[98] Y. Zhao, B. J. Lynch, and D. G. Truhlar, J. Phys. Chem. A 2004, 108, 4786.

[99] Y. Zhao, B. J. Lynch, and D. G. Truhlar, Phys. Chem. Chem. Phys. 2005, 7, 43.

[100] K. L. Bak, P. Jørgensen, J. Olsen, T. Helgaker, and W. Klopper, J. Chem. Phys. 2000, 112, 9229.

[101] J. Noga, P. Valiron, and W. Klopper, J. Chem. Phys. 2001, 115, 2022.

[102] T. Helgaker, W. Klopper, A. Halkier, K. Bak, P. Jørgensen, and J. Olsen, in QuantumMechanical Prediction of Thermochemical Data, Understanding Chemical Reactivity, vol. 22, J. Cioslowski, Ed., pp. 1-30, Springer Netherlands, 2002.

[103] P. Carlier, H. Hannachi, and G. Mouvier, Atmos. Environ. 1986, 20, 2079.

[104] J. M. Anglada and V. M. Domingo, J. Phys. Chem. A 2005, 109, 10786. 
[105] Q. S. Li, X. Zhang, and S. W. Zhang, J. Phys. Chem. A 2005, 109, 12027.

[106] P. Ehrenfreund and S. B. Charnley, Annu. Rev. Astron. Astrophys. 2000, 38, 427.

[107] T. J. Wallington, T. Ellermann, O. J. Nielsen, and J. Sehested, J. Phys. Chem. 1994, 98, 2346.

[108] T. Buckley, R. Johnson, R. Huie, Z. Zhang, S. Kuo, and R. Klemm, J. Phys. Chem. 1995, 99, 4879.

[109] R. Zander, C. P. Rinsland, E. Mahieu, M. R. Gunson, C. B. Farmer, M. C. Abrams, and M. K. W. Ko, J. Geophys. Res. : Atmospheres 1994, 99, 16737.

[110] A. R. Ravishankara, A. A. Turnipseed, N. R. Jensen, S. Barone, M. Mills, C. J. Howard, and S. Solomon, Science 1994, 263, 71.

[111] W. F. Schneider and T. J. Wallington, J. Phys. Chem. 1994, 98, 7448.

[112] A. Nölle, H. Heydtmann, R. Meller, W. Schneider, and G. K. Moortgat, Geophys. Res. Lett. 1992, 19, 281.

[113] T. J. Wallington, M. D. Hurley, J. C. Ball, and E. W. Kaiser, Environ. Sci. Tech. 1992, 26, 1318 .

[114] W.-H. Fang and R.-Z. Liu, J. Chem. Phys. 2001, 115, 10431.

[115] E. W. Kaiser and T. J. Wallington, J. Phys. Chem. 1994, 98, 5679.

[116] F. Wu and R. W. Carr, J. Phys. Chem. 1992, 96, 1743.

[117] R. Lesclaux, A. Dognon, and F. Caralp, J. Photochem. Photobiol. A 1987, 41, 1 .

[118] R. Jayanty, R. Simonaitis, and J. Heicklen, Journal of Photochemistry 1976, 5, 217.

[119] W. M. Fabian and R. Janoschek, J. Mol. Struct. (THEOCHEM) 2005, 713, 227.

[120] C. M. Rosado-Reyes and J. S. Francisco, J. Phys. Chem. A 2006, 110, 4419.

[121] I. R. Slage, F. Baiocchi, D. Gutman, J. Phys. Chem. 1978, 82, 1333.

[122] N. Balucani, P. Casavecchia, D. Stranges, G. G. Volpi, Chem. Phys. Lett. 1993, 211, 469.

[123] D. J. Grant, D. A. Dixon, J. S. Francisco, D. Feller, K. A. Peterson, J. Phys. Chem. A 2009, $113,11343$.

[124] J. F. Gleason, C. J. Howard, J. Phys. Chem. 1997, 92, 3414.

[125] W. Klopper, D. P. Tew, N. González Garía, M. Olzmann, J. Chem. Phys. 2008, 129, 114308. 
[126] S. W. Benson, The Foundations of Chemical Kinetics, McGraw-Hill Book Co., Inc., New York, 1960.

[127] C. Anastasi, M. Broomfield, O. J. Nielsen, and P. Pagsberg, J. Phys. Chem. 1992, 96, 696.

[128] G. S. Tyndall and A. R. Ravishankara, J. Phys. Chem. 1989, 93, 2426.

[129] F. Domine, A. R. Ravishankara, and C. J. Howard, J. Phys. Chem. 1992, 96, 2171.

[130] R. E. Stickel, M. Chin, E. P. Daykin, A. J. Hynes, P. H. Wine, and T. J. Wallington, J. Phys. Chem. 1993, 97, 13653.

[131] G. de Petris, M. Rosi, and A. Troiani, ChemPhysChem 2006, 7, 2352.

[132] T. H. Dunning Jr., J. Chem. Phys. 1989, 90, 1007.

[133] R. A. Kendall, T. H. Dunning Jr., and R. J. Harrison, J. Chem. Phys. 1992, 96, 6796.

[134] D. E. Woon and T. H. Dunning Jr., J. Chem. Phys. 1995, 103, 4572.

[135] A. K. Wilson, T. van Mourik, and T. H. Dunning Jr., J. Mol. Struct. (THEOCHEM) 1996, 388,339 .

[136] J. Gauss, in Encyclopedia of Computational Chemistry, vol. 1, P. v. R. Schleyer, N. L. Allinger, T. Clark, J. Gasteiger, P. A. Kollman, H. F. Schaeffer III, and P. R. Schreiner, Eds., pp. 615-636, John Wiley \& Sons, Limited, New York, USA, 1998.

[137] G. D. Purvis III and R. J. Bartlett, J. Chem. Phys. 1982, 76, 1910.

[138] J. Noga and R. J. Bartlett, J. Chem. Phys. 1987, 86, 7041.

[139] G. E. Scuseria and H. F. Schaefer III, Chem. Phys. Lett. 1988, 152, 382.

[140] K. Raghavachari, G. W. Trucks, J. A. Pople, and M. Head-Gordon, Chem. Phys. Lett. 1989, $157,479$.

[141] Y. J. Bomble, J. F. Stanton, M. Kállay, and J. Gauss, J. Chem. Phys. 2005, 123, 054101.

[142] M. Kállay and J. Gauss, J. Chem. Phys. 2005, 123, 214105.

[143] G. Tasi and A. G. Császár, Chem. Phys. Lett. 2007, 438, 139 .

[144] W. Klopper and W. Kutzelnigg, J. Mol. Struct. (THEOCHEM) 1986, 135, 339 .

[145] A. Karton and J. Martin, Theor. Chim. Acta 2006, 115, 330.

[146] T. Helgaker, W. Klopper, H. Koch, and J. Noga, J. Chem. Phys. 1997, 106, 9639. 
[147] J. Noga, S. Kedžuch, J. Šimunek, and S. Ten-no, J. Chem. Phys. 2008, 128, 174103.

[148] J. Noga and P. Valiron, Collect. Czech. Chem. Commun. 2003, 68, 340.

[149] S. Kedžuch, J. Noga, and P. Valiron, Mol. Phys. 2005, 103, 999.

[150] M. Douglas and N. M. Kroll, Ann. Phys. (N.Y.) 1974, 82, 89.

[151] B. A. Hess, Phys. Rev. A 1986, 33, 3742.

[152] H. Sellers and P. Pulay, Chem. Phys. Lett. 1984, 103, 463 .

[153] N. C. Handy and A. M. Lee, Chem. Phys. Lett. 1996, 252, 425.

[154] W. Kutzelnigg, Mol. Phys. 1997, 90, 909.

[155] E. F. Valeev and C. D. Sherrill, J. Chem. Phys. 2003, 118, 3921.

[156] J. Gauss, A. Tajti, M. Kállay, J. F. Stanton, and P. G. Szalay, J. Chem. Phys. 2006, 125, 144111.

[157] The Mainz-Austin-Budapest version of ACESII (now CFOUR), J. F. Stanton, J. Gauss, J. D. Watts, P. G. Szalay, R. J. Bartlett, with contributions from A. A. Auer, D. B. Bernholdt, O. Christiansen, M. E. Harding, M. Heckert, O. Heun, C. Huber, D. Jonsson, J. Jusélius, W. J. Lauderdale, T. Metzroth, C. Michauk, D. P. O’Neill, D. R. Price, K. Ruud, F. Schiffmann, M. E. Varner, J. Vázquez and the integral packages Molecule (J. Almlöf, P. R. Taylor), Props (P. R. Taylor), and ABACUS (T. Helgaker, H. J. Aa Jensen, P. Jørgensen, J. Olsen). For more information, see ref 200 or visit http://cfour.de.

[158] J. Gauss and J. F. Stanton, Chem. Phys. Lett. 1997, 276, 70.

[159] P. G. Szalay, J. Gauss, and J. F. Stanton, Theor. Chim. Acta 1998, 100, 5.

[160] G. Herzberg and A. Monfils, J. Mol. Spectrosc. 1960, 5, 482.

[161] H. Telle and U. Tell, J. Mol. Spectrosc. 1981, 85, 248.

[162] P. Barletta, S. V. Shirin, N. F. Zobov, O. L. Polyansky, J. Tennyson, E. F. Valeev, and A. G. Császár, J. Chem. Phys. 2006, 125, 204307.

[163] O. L. Polyansky, A. G. Császár, S. V. Shirin, N. F. Zobov, P. Barletta, J. Tennyson, D. W. Schwenke, and P. J. Knowles, Science 2003, 299, 539.

[164] K. L. Bak, J. Gauss, P. Jørgensen, J. Olsen, T. Helgaker, and J. F. Stanton, J. Chem. Phys. 2001, 114, 6548 .

[165] D. Feller, J. Chem. Phys. 1992, 96, 6104. 
[166] I. M. Mills, in Molecular Spectroscopy: Modern Research, K. N. Rao and C. W. Mathews, Eds., Academic Press, New York, 1972.

[167] J. F. Stanton and J. Gauss, Int. Rev. Phys. Chem. 2000, 19, 61.

[168] Y. Ralchenko, A. E. Kramida, J. Reader, and NIST ASD Team, NIST Atomic Spectra Database (version 4.1.0), [Online]. Available: http://physics.nist.gov/asd3 (accessed July 2011), National Institute of Standards and Technology, Gaithersburg, MD.

[169] D. A. McQuarrie and J. D. Simon, Molecular Thermodynamics, University Science Books, Sausalito, CA, 1999.

[170] C. W. Bauschlicher and H. Partridge, Chemical Physics Letters 1995, 240, 533.

[171] J. Martin and O. Uzan, Chem. Phys. Lett. 1998, 282, 16.

[172] J. M. L. Martin, J. Chem. Phys. 1998, 108, 2791.

[173] C. W. Bauschlicher Jr and A. Ricca, J. Phys. Chem. A 1998, 102, 8044.

[174] A. K. Wilson and T. H. Dunning Jr, J. Phys. Chem. A 2004, 108, 3129.

[175] A. K. Wilson and T. H. Dunning Jr, J. Chem. Phys. 2003, 119, 11712.

[176] T. H. Dunning Jr, K. A. Peterson, and A. K. Wilson, J. Chem. Phys. 2001, 114, 9244.

[177] J. Csontos, Z. Rolik, S. Das, M. Kállay, J. Phys. Chem. A 2010, 114, 13093.

[178] C. Sosa, J. Geertsen, G. W. Trucks, R. J. Bartlett, and J. A. Franz, Chem. Phys. Lett. 1989, 159,148 .

[179] A. Landau, K. Khistyaev, S. Dolgikh, and A. I. Krylov, J. Chem. Phys. 2010, 132, 014109.

[180] Z. Rolik and M. Kállay, J. Chem. Phys. 2011, 134, 124111.

[181] J. W. Ochterski, Thermochemistry in Gaussian. Available online under White Papers and Technical Notes at hhtp://www.gaussian.com/g_tech/white.htm., 2000.

[182] J. M. Ricks and R. F. Barrow, Canadian Journal of Physics 1969, 47, 2423.

[183] P. W. J. M. Frederix, C. H. Yang, G. C. Groenenboom, D. H. Parker, K. Alnama, C. M. Western, and A. J. Orr-Ewing, J. Phys. Chem. A 2009, 113, 14995.

[184] P. Marshall, Y. Gao, and P. Glarborg, J. Chem. Phys. 2011, 135, 094301.

[185] Y. Gao and P. Marshall, J. Chem. Phys. 2011, 135, 144306.

[186] K. R. Jorgensen and A. K. Wilson, Comp. Theor. Chem. 2012, 991, 1 . 
[187] K. Pitzer and W. Gwinn, J. Chem. Phys. 1942, 10, 428.

[188] K. Pitzer, J. Chem. Phys. 1946, 14, 239.

[189] J. Kilpatrick and K. Pitzer, J. Chem. Phys. 1949, 17, 1064.

[190] J. Li and K. Pitzer, J. Phys. Chem. 1956, 60, 466.

[191] G. Ercolani, J. Chem. Edu. 2000, 77, 1495.

[192] J. Pfaendtner, X. Yu, and L. J. Broadbelt, Theor. Chem. Acc. 2007, 118, 881.

[193] C. Marston and G. Balint-Kurti, J. Chem. Phys. 1989, 91, 3571.

[194] G. Balint-Kurti, R. Dixon, and C. Marston, Int. Rev. Phys. Chem. 1992, 11, 317.

[195] Y. Y. Chuang and D. G. Truhlar, J. Chem. Phys. 2000, 112, 1221.

[196] B. A. Ellingson, V. A. Lynch, S. L. Mielke, and D. G. Truhlar, J. Chem. Phys. 2006, 125, 084305.

[197] J. Noga, W. Klopper, T. Helgaker, and P. Valiron, DIRCCR12-Os, a direct CCSD(T)-R12 program, 2003.

[198] H.-J. Werner, P. J. Knowles, R. Lindh, F. R. Manby, M. Schütz, and and others, Molpro, version 2012.2, a package of ab initio programs, 2012, see http://www.molpro.net.

[199] S. Carter, J. M. Bowman, and N. C. Handy, Theor. Chim. Acta 1998, 100, 191.

[200] CFour, a quantum chemical program package written by J. F. Stanton, J. Gauss, M. E. Harding, P. G. Szalay with contributions from A. A. Auer, R. J. Bartlett, U. Benedikt, C. Berger, D. E. Bernholdt, Y. J. Bomble, O. Christiansen, M. Heckert, O. Heun, C. Huber, T.-C. Jagau, D. Jonsson, J. Jusélius, K. Klein, W. J. Lauderdale, D. A. Matthews, T. Metzroth, D. P. O’Neill, D. R. Price, E. Prochnow, K. Ruud, F. Schiffmann, S. Stopkowicz, J. Vázquez, F. Wang, J. D. Watts and the integral packages MOLECULE (J. Almlöf and P. R. Taylor), PROPS (P. R. Taylor), ABACUS (T. Helgaker, H. J. Aa. Jensen, P. Jørgensen, and J. Olsen), and ECP routines by A. V. Mitin and C. van Wüllen. For the current version, see http://www.cfour.de.

[201] J. Csontos, Python scripts to calculate finite temperature thermodynamic properties from CFOUR outputs., 2013.

[202] P. Szakács, J. Csontos, S. Das, and M. Kállay, J. Phys. Chem. A 2011, 115, 3144.

[203] J. Duncan, Mol. Phys. 1974, 28, 1177. 
[204] K. Yamada, T. Nakagawa, K. Kuchitsu, and Y. Morino, J. Mol. Spectrosc. 1971, 38, 70.

[205] S. Carter and N. C. Handy, J. Mol. Spectrosc. 1996, 179, 65.

[206] J. Martin, J. Chem. Phys. 1998, 108, 2791.

[207] M. J. Bramley and J. Tucker Carrington, J. Chem. Phys. 1993, 99, 8519.

[208] H. Romanowski, J. M. Bowman, and L. B. Harding, J. Chem. Phys. 1985, 82, 4155.

[209] H. von Wartenberg and Lerner-Steinberg, Angew. Chem. 1925, 38, 591.

[210] M. Delepine and M. Badoche, C.R. Acad. Sci. 1942, 214, 777.

[211] R. H. Newton and B. F. Dodge, J. Am. Chem. Soc. 1933, 55, 4747.

[212] R. A. Fletcher and G. Pilcher, Trans. Faraday Soc. 1970, 66, 794.

[213] L. A. Curtiss, K. Raghavachari, P. C. Redfern, and J. A. Pople, J. Chem. Phys. 1997, 106, 1063.

[214] J. A. Montgomery, M. J. Frisch, J. W. Ochterski, and G. A. Petersson, J. Chem. Phys. 2000, $112,6532$.

[215] G. da Silva, J. W. Bozzelli, N. Sebbar, and H. Bockhorn, ChemPhysChem 2006, 7, 1119.

[216] D. L. Baulch, R. A. Cox, P. J. Crutzen, R. F. Hampson, J. A. Kerr, J. Troe, and R. T. Watson, J. Phys. Chem. Ref. Data 1982, 11, 327.

[217] J. B. Pedley, R. O. Naylor, and S. P. Kirby, Thermodynamic Data of Organic Compounds, 2nd ed., Chapman and Hall, London, 1986.

[218] L. V. Gurvich, I. V. Veyts, and C. B. Alcock, Thermodynamic Properties of Individual Substances, 4th ed., Hemisphere, New York, 1992.

[219] D. R. Stull, E. F. Westrum, and G. C. Sinke, The Chemical Thermodynamics of Organic Compounds, John Wiley \& Sons, Inc., New York, 1969.

[220] E. S. Domalski, D. Garvin, and D. D. Wagman, NBS Spec. Publ. (US) 1978, 513, Appendix 1.

[221] J. Chao, R. C. Wilhoit, and K. R. Hall, Thermochim. Acta 1980, 41, 41 .

[222] K. N. Marsh, R. C. Wilhoit, M. Frenkel, and D. Yin, Thermodynamic Properties of the Substances in Ideal Gas State: Linear and Non-Linear Function Coefficients Data Files and Computer Codes to Regenerate Values of Thermodynamic Properties, version 1.0M; Thermodynamics Research Center (TRC), The Texas Engineering Experiment Station (TEES), Texas A\&M University System: College Station, TX, 1994. 
[223] O. Ruff and S.-C. Li, Z. Anorg. Chem. 1939, 242, 272.

[224] H. von Wartenberg and G. Riteris, Z. Anorg. Chem. 1949, 258, 356.

[225] G. T. Armstrong, C. F. Coyle, and L. A. Krieger, Methane-Oxygen-Fluorine Flames Spectroscopic And Calorimetric Studies; WADTC TR 58-541, Carpenter Litho \& Prtg. Co., Springfield, OH, October 1958.

[226] R. L. Asher, E. H. Appelman, and B. Ruscic, J. Chem. Phys. 1996, 105, 9781.

[227] M. Hopper, J. Russell, and J. Overend, J. Chem. Phys. 1968, 48, 3765.

[228] M. H. Matus, M. T. Nguyen, D. A. Dixon, and K. O. Christe, J. Phys. Chem. A 2008, 112, 4973.

[229] J. A. Montgomery, H. H. Michels, and J. S. Francisco, Chem. Phys. Lett. 1994, 220, 391.

[230] D. Bakowies, J. Phys. Chem. A 2009, 113, 11517.

[231] M. Nyden, G. Linteris, D. Burgess Jr, P. Westmoreland, W. Tsang, and M. Zachariah, Evaluation of Alternative In-Flight and Dry Bays NIST SP 1995, 861, 467.

[232] N. Haworth, M. Smith, G. Bacskay, and J. Mackie, J. Phys. Chem. A 2000, 104, 7600.

[233] S. Kondo, A. Takahashi, K. Tokuhashi, A. Sekiya, Y. Yamada, and K. Saito, J. Fluorine Chem. 2002, 117, 47.

[234] J. C. Amphlett, J. R. Dacey, and G. O. Pritchard, J. Phys. Chem. 1971, 75, 3024.

[235] K. Sudlow and A. Woolf, J. Fluorine Chem. 1999, 96, 141.

[236] H. Henrici, M. C. Lin, and S. H. Bauer, J. Chem. Phys. 1970, 52, 5834.

[237] M. T. Bowers and M. Chau, J. Phys. Chem. 1976, 80, 1739.

[238] H. J. Gangloff, D. Milks, K. L. Maloney, T. N. Adams, and R. A. Matula, J. Chem. Phys. 1975, 63, 4915.

[239] V. D. Knyazev, A. Bencsura, and I. R. Slagle, J. Phys. Chem. A 1997, 101, 849.

[240] J. S. Francisco and Y. Zhao, J. Chem. Phys. 1990, 93, 9203.

[241] M. R. Zachariah, P. R. Westmoreland, P. R. Westmoreland, W. Tsang, and C. F. Melius, J. Phys. Chem. 1996, 100, 8737.

[242] R. Janoschek and M. J. Rossi, Int. J. Chem. Kinet. 2004, 36, 661.

[243] R. Janoschek and W. M. F. Fabian, J. Mol. Struct. 2006, 780-781, 80. 
[244] J. Breidung and W. Thiel, J. Phys. Chem. A 2006, 110, 1575.

[245] K. Macneil and J. Thynne, Int. J. Mass Spectr. Ion Phys. 1969, 3, 35.

[246] W. J. Hehre, R. Ditchfield, L. Radom, and J. A. Pople, J. Am. Chem. Soc. 1970, 92, 4796.

[247] J. A. Pople, L. Radom, and W. J. Hehre, J. Am. Chem. Soc. 1971, 93, 289.

[248] D. E. Milligan, M. E. Jacox, A. M. Bass, J. J. Comeford, and D. E. Mann, J. Chem. Phys. $\mathbf{1 9 6 5 ,} 42,3187$.

[249] M. Jacox, J. Phys. Chem. Ref. Data 2003, 32, 1.

[250] Y. Zhao and J. S. Francisco, Chem. Phys. Lett. 1990, 173, 551.

[251] M. N. Glukhovtsev and R. D. Bach, J. Phys. Chem. A 1997, 101, 3574.

[252] R. F. Stratton and A. H. Nielsen, J. Mol. Spectrosc. 1960, 4, 373 .

[253] H. W. Morgan, P. A. Staats, and J. H. Goldstein, J. Chem. Phys. 1956, 25, 337.

[254] T. L. Nguyen and M. T. Nguyen, J. Chem. Phys. 1999, 110, 684.

[255] I. Hisatsune and J. Heicklen, Can. J. Spectrosc. 1973, 18, 77.

[256] H. Takeo and C. Matsumura, J. Chem. Phys. 1976, 64, 4536.

[257] A. Nielsen, T. Burke, P. Woltz, and E. Jones, J. Chem. Phys. 1952, 20, 596.

[258] R. J. Lovell, C. V. Stephenson, and E. A. Jones, J. Chem. Phys. 1954, 22, 1953.

[259] A. Mirri, A. Guarnieri, P. Favero, and G. Zuliani, Il Nuovo Cimento (1955-1965) 1962, 25, 265.

[260] M. H. Back and A. H. Sehon, Can. J. Chem. 1960, 38, 1261.

[261] R. R. Bernecker and F. A. Long, J. Phys. Chem. 1961, 65, 1565.

[262] M. A. Haney and J. L. Franklin, Trans. Faraday Soc. 1969, 65, 1794.

[263] B. Ruscic, M. Schwarz, and J. Berkowitz, J. Chem. Phys. 1989, 91, 6780.

[264] B. Ruscic and M. Litorja, Chem. Phys. Lett. 2000, 316, 45.

[265] H. A. Schwarz and R. W. Dodson, J. Phys. Chem. 1989, 93, 409.

[266] J. L. Holmes, F. P. Lossing, and P. M. Mayer, J. Am. Chem. Soc. 1991, 113, 9723.

[267] D. Fulle, H. F. Hamann, H. Hippler, and J. Troe, J. Chem. Phys. 1996, 105, 983. 
[268] T. V. Duncan and C. E. Miller, J. Chem. Phys. 2000, 113, 5138.

[269] D. Yu, A. Rauk, and D. A. Armstrong, J. Chem. Soc. Perkin Trans. 2 1994, pp. 2207-2215.

[270] R. Janoschek and M. J. Rossi, Int. J. Chem. Kinet. 2002, 34, 550.

[271] B. Ruscic, M. Schwarz, and J. Berkowitz, J. Chem. Phys. 1989, 91, 6772.

[272] W. Gardiner Jr., D. Olson, and J. White, Chem. Phys. Lett. 1978, 53, 134.

[273] D. E. Milligan and M. E. Jacox, J. Chem. Phys. 1971, 54, 927.

[274] G. Kwei and R. Curl, J. Chem. Phys. 1960, 32, 1592.

[275] W. A. Shapley and G. B. Bacskay, J. Phys. Chem. A 1999, 103, 4505.

[276] F. E. Davidson, A. R. Clemo, G. L. Duncan, R. J. Browlet, J. H. Hobson, R. Grice, Mol. Phys. 1982, 46, 33.

[277] A. Goumri, D. Laasko, J-D. R. Rocha, C. E. Smith, P. Marshall, J. Chem. Phys. 1995, 102, 161.

[278] S. S. Xantheas, T. H. Dunning, Jr, J. Phys. Chem. 1993, 97, 18.

[279] S. S. Xantheas, T. H. Dunning, Jr, J. Phys. Chem. 1993, 97, 6616.

[280] P. A. Denis, Chem. Phys. Lett. 2004, 395, 12.

[281] M. A. Blitz, K. J. Hughes, M. J. Pilling, J. Phys. Chem. A 2003, 107, 1971.

[282] W. K. Li, M. L. McKee, J. Phys. Chem. A 1997, 101, 9778.

[283] H. Somnitz, Phys. Chem. Chem. Phys 2004, 6, 3844.

[284] R. Patrick and D. Golden, Int. J. Chem. Kinet. 1983, 15, 1189.

[285] J. Margitan, J. Phys. Chem. 1984, 88, 3314.

[286] A. Heynes, P. H. Wines, Kinetics and Mechanism of the Oxidation of Gaseous Sulfur Compounds. In Gas-Phase Combustion Chemistry, pp. 343-383, Springer-Verlag, 2000.

[287] Q. K. Timerghazin, G. H. Peslherbe, and A. M. English, Phys. Chem. Chem. Phys. 2008, $10,1532$.

[288] G. Black, R. Patrick, L. E. Jusinsky, T. G. Slanger, J. Chem. Phys. 1984, 80, 4065.

[289] M. T. Nguyen, D. Lahem, R. Flammang, Chem. Phys. Lett. 1998, 283, 357.

[290] A. G. Császár, M. L. Leininger, and A. Burcat, J. Phys. Chem. A 2003, 107, 2061. 
[291] V. H. Dibeler and S. K. Liston, J. Chem. Phys. 1968, 49, 482.

[292] B. Morrow, Can. J. Phys. 1966, 44, 2447.

[293] J. C. Traeger, Org. Mass Spectrom. 1984, 19, 514.

[294] H. F. Prest, W.-B. Tzeng, J. M. Brom Jr., and C. Y. Ng, Int. J. Mass Spectrom. Ion Phys. 1983, 50, 315.

[295] J. Berkowitz, G. B. Ellison, and D. Gutman, J. Phys. Chem. 1994, 98, 2744.

[296] S. Nourbakhsh, K. Norwood, H.-M. Yin, C.-L. Liao, and C. Y. Ng, J. Chem. Phys. 1991, 95, 946.

[297] J. M. Nicovich, K. D. Kreutter, C. A. Van Dijk, and P. H. Wine, J. Phys. Chem. 1992, 96, 2518.

[298] A. G. Császár, M. L. Leininger, and A. Burcat, J. Phys. Chem. A 2003, 107, 2061.

[299] L. R. Peebles and P. Marshall, J. Chem. Phys. 2002, 117, 3132.

[300] L. A. Curtiss, P. C. Redfern, K. Raghavachari, V. Rassolov, and J. A. Pople, J. Chem. Phys. 1999, $110,4703$.

[301] S. Parthiban and J. M. L. Martin, J. Chem. Phys. 2001, 114, 6014.

[302] J. M. L. Martin and T. J. Lee, Chem. Phys. Lett. 1996, 258, 136.

[303] J. M. L. Martin, Chem. Phys. Lett. 1996, 259, 679.

[304] B. Rosen, Spectroscopic Data Relative to Diatomic Molecules, Pergamon Press, Oxford, 1970.

[305] E. Block, R. E. Penn, R. J. Olsen, and P. F. Sherwin, J. Am. Chem. Soc. 1976, 98, 1264.

[306] E. Block, H. Bock, S. Mohmand, P. Rosmus, and B. Solouki, Angew. Chem. Int. Ed. 1976, 15,383 .

[307] G. Bouchoux and J. Y. Salpin, J. Am. Chem. Soc. 1996, 118, 6516.

[308] S. W. Benson, Chem. Rev. 1978, 78, 23.

[309] P. J. A. Ruttink, P. C. Burgers, J. T. Francis, and J. K. Terlouw, J. Phys. Chem. 1996, 100, 9694.

[310] P. J. A. Ruttink, P. C. Burgers, M. A. Trikoupis, and J. K. Terlouw, Chem. Phys. Lett. 2001, $342,447$. 
[311] O. N. Ventura, M. Kieninger, R. E. Cachau, and S. Suhai, Chem. Phys. Lett. 2000, 329, 145.

[312] O. N. Ventura, M. Kieninger, P. A. Denis, and R. E. Cachau, J. Phys. Chem. A 2001, 105, 9912.

[313] O. N. Ventura, M. Kieninger, P. A. Denis, and R. E. Cachau, Chem. Phys. Lett. 2002, 355, 207.

[314] L. Heydorn, Y. Ling, G. de Oliveira, J. Martin, C. Lifshitz, and J. Terlouw, Z. Phys. Chem. 2001, 215, 141.

[315] C. Schwartz, Phys. Rev. 1962, 126, 1015.

[316] J. M. L. Martin, Chem. Phys. Lett. 1999, 310, 271 .

[317] B. Ruscic and J. Berkowitz, J. Chem. Phys. 1992, 97, 1818.

[318] L. A. Curtiss, R. H. Nobes, J. A. Pople, and L. Radom, J. Chem. Phys. 1992, 97, 6766.

[319] S.-W. Chiu, W.-K. Li, W.-B. Tzeng, and C.-Y. Ng, J. Chem. Phys. 1992, 97, 6557.

[320] M. L. McKee and P. H. Wine, J. Am. Chem. Soc. 2001, 123, 2344.

[321] A. J. Hynes, P. H. Wine, and J. M. Nicovich, J. Phys. Chem. 1988, 92, 3846.

[322] T. P. Murrells, E. R. Lovejoy, and A. R. Ravishankara, J. Phys. Chem. 1990, 94, 2381.

[323] E. W. G. Diau and Y. P. Lee, J. Phys. Chem. 1991, 95, 379.

[324] M. L. McKee, Chem. Phys. Lett. 1993, 201, 41. 


\section{Függelék}

\section{F. 1. táblázat}

CCSD(T)/cc-pVQZ szinten számított kötéshosszak (Å-ben), valamint kötésszögek és torziós szögek (fokban). Az egyensúlyi geometriákat az 5.1. ábra mutatja be grafikusan.

\begin{tabular}{|c|c|c|c|}
\hline Szpéciesz & Kötéshossz & Kötésszög & Torziós szög \\
\hline \multirow[t]{2}{*}{$\mathrm{H}_{2} \mathrm{CO}^{\mathrm{a}}$} & $R(\mathrm{CH})=1.10074$ & $\angle(\mathrm{HCO})=121.69$ & $D(\mathrm{HCOH})=180.00$ \\
\hline & $R(\mathrm{CO})=1.20524$ & $\angle(\mathrm{HCH})=116.62$ & \\
\hline \multirow[t]{2}{*}{$\mathrm{F}_{2} \mathrm{CO}$} & $R(\mathrm{CF})=1.30862$ & $\angle(\mathrm{FCO})=126.06$ & $D(\mathrm{FCOF})=180.00$ \\
\hline & $R(\mathrm{CO})=1.17053$ & $\angle(\mathrm{FCF})=107.88$ & \\
\hline \multirow[t]{2}{*}{$\mathrm{FCO}$} & $R(\mathrm{CF})=1.32289$ & $\angle(\mathrm{FCO})=127.78$ & \\
\hline & $R(\mathrm{CO})=1.16728$ & & \\
\hline \multirow[t]{3}{*}{$\mathrm{HFCO}$} & $R(\mathrm{CH})=1.08896$ & $\angle(\mathrm{HCO})=127.61$ & $D(\mathrm{HCOF})=180.00$ \\
\hline & $R(\mathrm{CF})=1.33682$ & $\angle(\mathrm{FCO})=122.82$ & \\
\hline & $R(\mathrm{CO})=1.17793$ & & \\
\hline \multirow[t]{3}{*}{$\mathrm{HClCO}$} & $R(\mathrm{CH})=1.09073$ & $\angle(\mathrm{HCO})=126.29$ & $D(\mathrm{HCOCl})=180.00$ \\
\hline & $R(\mathrm{CCl})=1.76609$ & $\angle(\mathrm{ClCO})=123.51$ & \\
\hline & $R(\mathrm{CO})=1.18183$ & & \\
\hline \multirow[t]{3}{*}{$\mathrm{FClCO}$} & $R(\mathrm{CF})=1.32082$ & $\angle(\mathrm{FCO})=124.10$ & $D(\mathrm{FCOCl})=180.00$ \\
\hline & $R(\mathrm{CCl})=1.72607$ & $\angle(\mathrm{ClCO})=126.35$ & \\
\hline & $R(\mathrm{CO})=1.17303$ & & \\
\hline \multirow[t]{3}{*}{ cisz-HOCO } & $R(\mathrm{C}=\mathrm{O})=1.18149$ & $\angle(\mathrm{COH})=108.10$ & $D(\mathrm{HOCO})=0.00$ \\
\hline & $R(\mathrm{C}-\mathrm{O})=1.32642$ & $\angle(\mathrm{OCO})=130.28$ & \\
\hline & $R(\mathrm{OH})=0.97020$ & & \\
\hline \multirow[t]{3}{*}{ transz-HOCO } & $R(\mathrm{C}=\mathrm{O})=1.17630$ & $\angle(\mathrm{COH})=107.83$ & $D(\mathrm{HOCO})=180.00$ \\
\hline & $R(\mathrm{C}-\mathrm{O})=1.33928$ & $\angle(\mathrm{OCO})=127.09$ & \\
\hline & $R(\mathrm{OH})=0.96068$ & & \\
\hline \multirow[t]{3}{*}{$\mathrm{NH}_{2} \mathrm{CO}^{\mathrm{b}}$} & $R(\mathrm{CO})=1.19092$ & $\angle(\mathrm{NCO})=129.74$ & $D\left(\mathrm{H}_{s} \mathrm{NCO}\right)=180.00$ \\
\hline & $R(\mathrm{CN})=1.33941$ & $\angle\left(\mathrm{H}_{s} \mathrm{NC}\right)=120.68$ & $D\left(\mathrm{H}_{a} \mathrm{NCO}\right)=0.00$ \\
\hline & $R\left(\mathrm{NH}_{s}\right)=1.00721$ & $\angle\left(\mathrm{H}_{a} \mathrm{NC}\right)=119.92$ & \\
\hline
\end{tabular}

Folytatás a következő oldalon... 
F. 1. táblázat - Folytatás az előző oldalról

\begin{tabular}{|c|c|c|c|}
\hline Szpéciesz & Kötéshossz & Kötésszög & Torziós szög \\
\hline & $R\left(\mathrm{NH}_{a}\right)=0.99832$ & & \\
\hline \multirow[t]{2}{*}{$\mathrm{HSO}$} & $R(\mathrm{SO})=1.50169$ & $\angle(\mathrm{OSH})=104.46$ & \\
\hline & $R(\mathrm{SH})=1.36721$ & & \\
\hline \multirow[t]{2}{*}{$\mathrm{SOH}$} & $R(\mathrm{SO})=1.63627$ & $\angle(\mathrm{SOH})=107.82$ & \\
\hline & $R(\mathrm{OH})=0.96193$ & & \\
\hline \multirow[t]{4}{*}{$\mathrm{HOSO}_{2}{ }^{\mathrm{c}}$} & $R\left(\mathrm{SO}_{1}\right)=1.61371$ & $\angle\left(\mathrm{HO}_{1} \mathrm{~S}\right)=107.34$ & $D\left(\mathrm{O}_{2} \mathrm{SO}_{1} \mathrm{H}\right)=26.09$ \\
\hline & $R\left(\mathrm{SO}_{2}\right)=1.44671$ & $\angle\left(\mathrm{O}_{1} \mathrm{SO}_{2}\right)=107.95$ & $D\left(\mathrm{O}_{3} \mathrm{SO}_{1} \mathrm{H}\right)=159.84$ \\
\hline & $R\left(\mathrm{SO}_{3}\right)=1.43848$ & $\angle\left(\mathrm{O}_{1} \mathrm{SO}_{3}\right)=105.77$ & \\
\hline & $R\left(\mathrm{HO}_{1}\right)=0.96582$ & $\angle\left(\mathrm{O}_{2} \mathrm{SO}_{3}\right)=123.33$ & \\
\hline \multirow[t]{3}{*}{ transz-HSNO } & $R(\mathrm{SH})=1.33693$ & $\angle(\mathrm{HSN})=90.33$ & $D(\mathrm{ONSH})=180.00$ \\
\hline & $R(\mathrm{SN})=1.85183$ & $\angle(\mathrm{ONS})=114.53$ & \\
\hline & $R(\mathrm{NO})=1.17645$ & & \\
\hline \multirow[t]{3}{*}{ cisz-HSNO } & $R(\mathrm{SH})=1.34355$ & $\angle(\mathrm{HSN})=95.11$ & $D(\mathrm{ONSH})=0.00$ \\
\hline & $R(\mathrm{SN})=1.83490$ & $\angle(\mathrm{ONS})=115.83$ & \\
\hline & $R(\mathrm{NO})=1.18029$ & & \\
\hline $\mathrm{SH}$ & $R(\mathrm{SH})=1.34175$ & & \\
\hline \multirow[t]{4}{*}{$\mathrm{CH}_{2} \mathrm{SO}^{\mathrm{d}}$} & $R(\mathrm{SO})=1.47336$ & $\angle(\mathrm{CSO})=114.69$ & $D\left(\mathrm{H}_{1} \mathrm{CSO}\right)=0.00$ \\
\hline & $R(\mathrm{SC})=1.61317$ & $\angle\left(\mathrm{H}_{1} \mathrm{CS}\right)=122.96$ & $D\left(\mathrm{H}_{2} \mathrm{CSO}\right)=180.00$ \\
\hline & $R\left(\mathrm{H}_{1} \mathrm{C}\right)=1.07911$ & $\angle\left(\mathrm{H}_{2} \mathrm{CS}\right)=115.48$ & \\
\hline & $R\left(\mathrm{H}_{2} \mathrm{C}\right)=1.07921$ & & \\
\hline \multirow[t]{4}{*}{$\mathrm{CH}_{2} \mathrm{SH}^{\mathrm{e}}$} & $R\left(\mathrm{H}_{1} \mathrm{~S}\right)=1.33711$ & $\angle\left(\mathrm{H}_{1} \mathrm{SC}\right)=97.63$ & $D\left(\mathrm{H}_{1} \mathrm{SCH}_{2}\right)=0.00$ \\
\hline & $R(\mathrm{SC})=1.71659$ & $\angle\left(\mathrm{H}_{2} \mathrm{CS}\right)=121.56$ & $D\left(\mathrm{H}_{1} \mathrm{SCH}_{3}\right)=180.00$ \\
\hline & $R\left(\mathrm{H}_{2} \mathrm{~S}\right)=1.07343$ & $\angle\left(\mathrm{H}_{3} \mathrm{CS}\right)=116.98$ & \\
\hline & $R\left(\mathrm{H}_{3} \mathrm{~S}\right)=1.07439$ & $\angle\left(\mathrm{H}_{2} \mathrm{CH}_{3}\right)=121.46$ & \\
\hline \multirow[t]{4}{*}{$\mathrm{S}_{2} \mathrm{COH}^{\mathrm{f}}$} & $R\left(\mathrm{~S}_{1} \mathrm{C}\right)=1.66583$ & $\angle\left(\mathrm{S}_{1} \mathrm{CS}_{2}\right)=111.49$ & $D\left(\mathrm{~S}_{1} \mathrm{COH}\right)=0.00$ \\
\hline & $R\left(\mathrm{~S}_{2} \mathrm{C}\right)=1.66476$ & $\angle\left(\mathrm{S}_{1} \mathrm{CO}\right)=126.16$ & $D\left(\mathrm{~S}_{2} \mathrm{COH}\right)=180.00$ \\
\hline & $R(\mathrm{CO})=1.32276$ & $\angle\left(\mathrm{S}_{2} \mathrm{CO}\right)=122.35$ & \\
\hline & $R(\mathrm{OH})=0.96619$ & $\angle(\mathrm{COH})=107.90$ & \\
\hline \multirow[t]{4}{*}{$\mathrm{SCSOH}^{\mathrm{g}}$} & $R\left(\mathrm{~S}_{1} \mathrm{C}\right)=1.57014$ & $\angle\left(\mathrm{S}_{1} \mathrm{CS}_{2}\right)=163.27$ & $D\left(\mathrm{OS}_{2} \mathrm{CS}_{1}\right)=-2.93$ \\
\hline & $R\left(\mathrm{~S}_{2} \mathrm{C}\right)=1.59514$ & $\angle\left(\mathrm{CS}_{2} \mathrm{O}\right)=110.58$ & $D\left(\mathrm{HOS}_{2} \mathrm{C}\right)=77.22$ \\
\hline & $R\left(\mathrm{~S}_{2} \mathrm{O}\right)=1.70201$ & $\angle\left(\mathrm{S}_{2} \mathrm{OH}\right)=107.21$ & \\
\hline & $R(\mathrm{OH})=0.96304$ & & \\
\hline
\end{tabular}

Folytatás a következő oldalon... 
F. 1. táblázat - Folytatás az előző oldalról

\begin{tabular}{llll}
\hline \hline Szpéciesz & Kötéshossz & Kötésszög & Torziós szög \\
\hline \hline
\end{tabular}

${ }^{a} \operatorname{CCSD}(\mathrm{T}) / a u g-c c-p C V Q Z$ szintû egyensúlyi geometria.

${ }^{\mathrm{b}} \mathrm{A}_{s}$ és $\mathrm{H}_{a}$ jelölések a hidrogénatomok karbonil-oxigénhez képesti szin és anti pozíciójára utalnak.

${ }^{c} \mathrm{O}_{1}$ : Az oxigénatom, amelyhez a hidrogén kapcsolódik. $\mathrm{O}_{2}$ : A H-atomhoz képest szin helyzetű O-atom. $\mathrm{O}_{3}$ : A $\mathrm{H}$-atomhoz képest anti helyzetú O-atom.

${ }^{\mathrm{d}} \mathrm{H}_{1}$ : az $\mathrm{O}$-atomhoz képest szin helyzetû hidrogénatom, $\mathrm{H}_{2}$ : az O-atomhoz képest anti helyzetú hidrogénatom.

e $\mathrm{H}_{1}$ : a kénatomhoz kapcsolódó $\mathrm{H}$-atom, $\mathrm{H}_{2}$ : szin pozíciójú hidrogén a $\mathrm{H}_{1}$-atomhoz képest, $\mathrm{H}_{3}$ : anti pozíciójú hidrogén a $\mathrm{H}_{1}$-atomhoz képest.

f $\mathrm{S}_{1}$ : A hidrogénatomhoz képest szin pozíció, $\mathrm{S}_{2}$ : a H-atomhoz képest anti pozíció.

g $\mathrm{S}_{2}$ : Az oxigénhez kapcsolódó kénatom.

F. 2. táblázat

A formaldehid molekula különböző bázisokkal optimalizált CCSD(T) szintû egyensúlyi geometriája

\begin{tabular}{lcccc}
\hline \hline Bázis & $\begin{array}{c}\text { Bázisfüggvények } \\
\text { száma }\end{array}$ & $R(\mathrm{C}-\mathrm{H}) / \AA$ & $R(\mathrm{C}=\mathrm{O}) / \AA$ & $\angle(\mathrm{H}-\mathrm{C}=\mathrm{O}) /^{\circ}$ \\
\hline \hline cc-pVDZ & 38 & 1.11892 & 1.21510 & 122.39 \\
cc-pCVDZ & 46 & 1.11858 & 1.21414 & 122.39 \\
aug-cc-pVDZ & 64 & 1.11440 & 1.22183 & 121.68 \\
aug-cc-pCVDZ & 72 & 1.11414 & 1.22048 & 121.69 \\
cc-pVTZ & 88 & 1.09863 & 1.20650 & 121.91 \\
cc-pCVTZ & 114 & 1.10225 & 1.20709 & 121.91 \\
aug-cc-pVTZ & 138 & 1.09898 & 1.20732 & 121.77 \\
aug-cc-pCVTZ & 164 & 1.10197 & 1.20925 & 121.70 \\
cc-pVQZ & 170 & 1.09956 & 1.20421 & 121.78 \\
cc-pCVQZ & 228 & 1.10076 & 1.20431 & 121.78 \\
aug-cc-pVQZ & 252 & 1.10013 & 1.20509 & 121.71 \\
aug-cc-pCVQZ & 310 & 1.10074 & 1.20524 & 121.69 \\
cc-pV5Z & 292 & 1.09828 & 1.20333 & 121.71 \\
\hline \hline
\end{tabular}


F. 3. táblázat

A HEAT-345+d(Q) modell tesztkészletének CCSD(T)/cc-pVQZ és cc-pV(Q+d)Z szintû geometriai paraméterei. A kötéshosszak $\AA$, a kötésszögek ${ }^{\circ}$ egységben szerepelnek.

Szpéciesz Kötéshossz cc-pVQZ cc-pV(Q+d)Z Kötésszög cc-pVQZ cc-pV(Q+d)Z

\begin{tabular}{lllllll}
\hline \hline $\mathrm{S}_{2}$ & $R(\mathrm{~S}-\mathrm{S})$ & 1.89983 & 1.89421 & & & \\
$\mathrm{H}_{2} \mathrm{~S}$ & $R(\mathrm{H}-\mathrm{S})$ & 1.33710 & 1.33540 & $\angle(\mathrm{HSH})$ & 92.28 & 92.27 \\
$\mathrm{SO}$ & $R(\mathrm{~S}-\mathrm{O})$ & 1.48832 & 1.48291 & & & \\
$\mathrm{SO}_{2}$ & $R(\mathrm{~S}-\mathrm{O})$ & 1.43946 & 1.43293 & $\angle(\mathrm{OSO})$ & 118.97 & 119.42 \\
\hline \hline
\end{tabular}

F. 4. táblázat

A tesztkészlet kísérleti szerkezeti paraméterei. Az adatok az NIST-JANAF adatbázisból ${ }^{19}$ származnak.

\begin{tabular}{lcccc}
\hline \hline Szpéciesz & \multicolumn{2}{c}{ Kötéshossz / $\mathrm{A}$} & \multicolumn{2}{c}{ Kötésszög / } \\
\hline \hline $\mathrm{S}_{2}$ & $R(\mathrm{~S}-\mathrm{S})$ & 1.889 & & \\
$\mathrm{H}_{2} \mathrm{~S}$ & $R(\mathrm{H}-\mathrm{S})$ & 1.328 & $\angle(\mathrm{HSH})$ & 92.2 \\
$\mathrm{SO}$ & $R(\mathrm{~S}-\mathrm{O})$ & 1.4811 & & \\
$\mathrm{SO}_{2}$ & $R(\mathrm{~S}-\mathrm{O})$ & 1.432 & $\angle(\mathrm{OSO})$ & 119.53 \\
\hline \hline
\end{tabular}

F. 5. táblázat

A $\mathrm{CH}_{2} \mathrm{SO}$ gyök anharmonicitási konstansainak alsó háromszög mátrixa.

Az értékek $\mathrm{cm}^{-1}$ egységben szerepelnek.

\begin{tabular}{l|rrrrrrrrr} 
& \multicolumn{1}{|c}{1} & \multicolumn{1}{c}{2} & 3 & 4 & 5 & 6 & 7 & 8 & 9 \\
\hline 1 & 0.7 & & & & & & & & \\
2 & 0.3 & 0.5 & & & & & & & \\
3 & -0.5 & -1.8 & -2.7 & & & & & & \\
4 & -0.3 & -1.5 & -1.8 & -2.5 & & & & & \\
5 & 72.6 & 0.5 & -3.9 & -3.2 & -72.1 & & & & \\
6 & -5.3 & -4.3 & 4.3 & 2.0 & -2.9 & 0.2 & & & \\
7 & -106.6 & -10.6 & -18.0 & -1.5 & -2.6 & -3.1 & -8.7 & & \\
8 & -7.7 & -9.0 & -3.6 & -3.5 & -5.5 & -3.4 & -3.2 & -6.1 & \\
9 & -1.2 & -1.0 & -1.1 & -8.7 & -5.8 & -21.0 & -27.8 & -112.5 & -30.9
\end{tabular}


F. 6. táblázat

A HSNO gyök anharmonicitási konstansainak alsó háromszög mátrixa. Az értékek $\mathrm{cm}^{-1}$ egységben szerepelnek.

\begin{tabular}{r|rrrrrc} 
& 1 & 2 & 3 & 4 & 5 & 6 \\
\hline 1 & 0.3 & & & & & \\
2 & -2.6 & -3.4 & & & & \\
3 & -5.2 & 6.6 & -1.4 & & & \\
4 & -6.8 & -2.0 & -4.1 & 4.2 & & \\
5 & -5.8 & -4.0 & -14.5 & 7.0 & -3.4 & \\
6 & -4.6 & 4.5 & -14.7 & -18.2 & -0.9 & -48.1
\end{tabular}

F. 7. táblázat

A $\mathrm{HOSO}_{2}$ gyök anharmonicitási konstansainak alsó háromszög mátrixa. Az értékek $\mathrm{cm}^{-1}$ egységben szerepelnek.

\begin{tabular}{l|rrrrrrrrr} 
& \multicolumn{1}{|c}{1} & 2 & 3 & 4 & 5 & 6 & 7 & 8 & 9 \\
\hline 1 & 1.5 & & & & & & & & \\
2 & -12.1 & -5.7 & & & & & & & \\
3 & -3.7 & -4.4 & -0.7 & & & & & & \\
4 & 6.8 & -4.5 & -6.7 & -1.3 & & & & & \\
5 & -1.1 & -1.2 & -4.4 & -0.8 & 0.4 & & & & \\
6 & -1.6 & -2.6 & -0.1 & -0.8 & -2.7 & -2.8 & & & \\
7 & 0.1 & -3.5 & -0.4 & -0.4 & -2.5 & -2.7 & 1.7 & & \\
8 & -4.0 & -0.3 & -5.7 & -1.5 & -5.2 & -0.2 & -0.9 & -4.1 & \\
9 & -1.5 & -14.6 & -0.9 & -7.9 & -6.4 & -21.9 & -6.0 & -2.5 & -82.4
\end{tabular}


F. 8. táblázat

A $\mathrm{CH}_{2} \mathrm{SH}$ gyök anharmonicitási konstansainak alsó háromszög mátrixa. Az értékek $\mathrm{cm}^{-1}$ egységben szerepelnek.

\begin{tabular}{l|rrrrrrrrr} 
& \multicolumn{1}{c}{1} & \multicolumn{1}{c}{2} & \multicolumn{1}{c}{3} & \multicolumn{1}{c}{4} & 5 & 6 & 7 & 8 & 9 \\
\hline 1 & 625.5 & & & & & & & & \\
2 & 324.4 & 14.4 & & & & & & & \\
3 & -20.4 & 15.0 & 1.0 & & & & & & \\
4 & -25.2 & -79.1 & -86.9 & 18.7 & & & & & \\
5 & -0.2 & -37.8 & -0.4 & 1.2 & -11.4 & & & & \\
6 & -57.0 & -32.0 & 0.5 & -0.9 & -5.5 & -5.0 & & & \\
7 & -4.8 & -4.1 & -4.5 & -3.7 & -4.9 & -4.7 & -1.5 & & \\
8 & -0.8 & -0.3 & -1.7 & -5.2 & -13.2 & -4.9 & -5.2 & -7.5 & \\
9 & -1.2 & -5.4 & -20.9 & -48.8 & -0.3 & -0.3 & -28.3 & -113.5 & -31.9
\end{tabular}

F. 9. táblázat

A $\mathrm{S}_{2} \mathrm{COH}$ gyök anharmonicitási konstansainak alsó háromszög mátrixa. Az értékek $\mathrm{cm}^{-1}$ egységben szerepelnek.

\begin{tabular}{l|rrrrrrrrr} 
& 1 & 2 & 3 & 4 & 5 & 6 & 7 & 8 & 9 \\
\hline 1 & -1.0 & & & & & & & & \\
2 & -0.3 & 2.3 & & & & & & & \\
3 & 1.7 & -1.7 & -3.6 & & & & & & \\
4 & -1.2 & -1.6 & -2.1 & 0.0 & & & & & \\
5 & 0.4 & -0.4 & 0.3 & -3.0 & 0.7 & & & & \\
6 & -4.0 & -1.6 & -0.8 & -9.4 & -1.7 & -4.5 & & & \\
7 & -2.1 & -3.8 & -1.2 & -12.9 & -0.8 & -2.9 & 8.7 & & \\
8 & 6.9 & -0.9 & -3.1 & -6.7 & -2.5 & 4.4 & -0.8 & -3.2 & \\
9 & -5.0 & -6.7 & -1.3 & -9.3 & -16.1 & -10.5 & -7.8 & -14.6 & -88.3
\end{tabular}


F. 10. táblázat

A SCSOH gyök anharmonicitási konstansainak alsó háromszög mátrixa. Az értékek $\mathrm{cm}^{-1}$ egységben szerepelnek.

\begin{tabular}{l|rrrrrrrrr} 
& \multicolumn{1}{c}{1} & \multicolumn{1}{c}{2} & \multicolumn{1}{c}{3} & \multicolumn{1}{c}{4} & 5 & 6 & 7 & 8 & 9 \\
\hline 1 & 0.0 & & & & & & & & \\
2 & 0.1 & 0.7 & & & & & & & \\
3 & -2.2 & 6.0 & 3.1 & & & & & & \\
4 & 2.8 & -8.8 & 0.1 & -14.6 & & & & & \\
5 & -2.8 & -16.0 & -4.4 & 0.4 & 3.0 & & & & \\
6 & 3.7 & -4.9 & -4.0 & 1.0 & -11.0 & -2.1 & & & \\
7 & -2.5 & 5.4 & -1.0 & 0.1 & -0.7 & -6.6 & 0.6 & & \\
8 & -6.6 & -0.5 & -13.4 & -0.3 & -14.4 & 12.9 & -2.5 & -1.5 & \\
9 & 1.1 & -5.8 & 0.0 & -10.0 & 4.0 & -21.8 & -14.1 & 0.6 & -85.7
\end{tabular}

